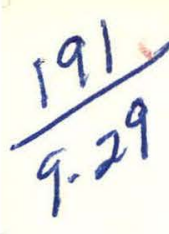

\title{
PROPERTIES OF CARBON DERIVED FROM INDENE COMPOUNDS
}
W. E. Smith
O. J. Horne, Jr
B. Napier, Jr
E. A. Larson
W. L. Harper

\section{UNION CARBIDE CORPORATION}

\section{NUCLEAR DIVISION} OAK RIDGE Y-12 PLANT

operated for the ATOMIC ENERGY COMMISSION under U. S. GOVERNMENT Contract W-7405 eng 26 


\section{DISCLAIMER}

This report was prepared as an account of work sponsored by an agency of the United States Government. Neither the United States Government nor any agency Thereof, nor any of their employees, makes any warranty, express or implied, or assumes any legal liability or responsibility for the accuracy, completeness, or usefulness of any information, apparatus, product, or process disclosed, or represents that its use would not infringe privately owned rights. Reference herein to any specific commercial product, process, or service by trade name, trademark, manufacturer, or otherwise does not necessarily constitute or imply its endorsement, recommendation, or favoring by the United States Government or any agency thereof. The views and opinions of authors expressed herein do not necessarily state or reflect those of the United States Government or any agency thereof. 


\section{DISCLAIMER}

Portions of this document may be illegible in electronic image products. Images are produced from the best available original document. 
Printed in the United States of America. Available from National Technical Information Service

U.S. Department of Commerce

5285 Port Royal Road, Springfield, Virginia 22151

Price: Printed Copy $\$ 3.00$; Microfiche $\$ 0.95$

This report was prepared as an account of work sponsored by the United States Government. Neither the United States nor the United States Atomic Energy Commission, nor any of their employees, nor any of their contractors, subcontractors, or their employees, makes any warranty, express or implied, or assumes any legal liability or responsibility for the accuracy, completeness or usefulness of any information, apparatus, product or process disclosed, or represents that its use would not infringe privately owned rights.

Reference to a company or product name does not imply approval or recommendation of the product by Union Carbide Corporation or the U S Atomic Energy Commission to the exclusion of others that may meet specifications. 


\title{
PROPERTIES OF CARBON DERIVED FROM INDENE COMPOUNDS
}

\author{
W. E. Smith \\ O. J. Horne, dr \\ B. Napier, Jr \\ E. A. Larson \\ W. L. Harper
}

Oak Ridge Y-12 Plant

P.O. Box Y, Oak Ridge, Tennessee 37830

operated for the U.S. ATOMIC ENERGY COMMISSION bY UNION CARBIDE CORPORATION-NUCLEAR DIVISION

under Contract W-7405-eng-26

Date |ssued - September 15, 1971

This was prepared as an account of work This roport was prepared as ances sponsored by the United States Atonic Energy the United States nor the Unifed States Aton, nor any of Commission, nor any of their employees, nor any uf their contractors, subcontractors, or their employees, makes any wairanty, express or implied, or assumes any legal liability or responsibility for the accuracy, comlegal liability or ressess or usefulness of any information, apparatus, product or process disclosed, or represents th would not infringe privately owned rights 


\section{THIS PAGE WAS INTENTIONALLY LEFT BLANK $:$}

, 
DISTRIBUTION

Aerojet-General

Swope, L. S./Funk, Campbell

Aerospace Corporation-El Segundo

Blaes, H. M., II

Aerospace Corporation-

San Bernardino

Schorr, W.E.

Aerotherm Corporation

Rodriquez, D. A.

Airco-Speer Carbon Company

Parker, W. E.

Ashland Oil and Refining Company

Newman, J. W.

A. S. Thomos, Incorporated

Shoffner, J. E.

Atomic Energy Commission-ORO

Keller, C. A.

Zachry, D. S., Jr

Auburn University

Stevens, F. J.

Arco Applied Technical Division

Lurie, R. M.
Avco Space Systems Division

Munson, T. R.

Battelle Memorial Institute

Duckworth, W. H.

Carborundum Company-Niagara Falls

Batha, H. D.

Carborundum Company-Sanborn

Wise, D. C.

Collier and Chemical Corporation

Scott, C. B.

Defense Atomic Support Agency-

Washington, DC

Atkins, M. C./ADDS T

Department of the Navy

Thompson, R. G.

General Electric

Gorsuch, P. D.

Great Lakes Carbon Corporation

Parry, S. J. S.

Great Lakes Research Corporation

Whittaker, M. P. 
Gulf-General Atomic

Bokros, J. C.

Engle, G. B.

White, J. L.

HITCO Corporation

Allison, $M$.

Kirtland Air Force Base

Gerber, J., Capt.

Rizzo, H., Col.

Lawrence Radiation Laboratory

Dorough, G. D.

Hanson, E. R.

Lockheed Missiles and Space Company

Johnson, A. C.

Los Alamos Scientific Laboratory

Armenis, N. P.

Baker, R. D.

Bowritiu, M. G.

Lyon, L. L.

Rowley, J.C.

Smith, M. C.

Taub, J. $M$.

Wewerka, E. M.

LTV Missiles and Space Division

Forcht, B. A.

LVT Research Center

Peterson, D. H.

McDonnell-Douglas Astronautics

Company-Santa Monica

Meyer, R. A.

Shapiro, 1.
McDonnell-Douglas Astronautics

Company-St. Lovis

Lang, G. D.

Masek, R. V.

NASA-AMES Research Center

Larson, H. K.

Lundell, J. H.

NASA-Langley Research Center

Maahs, H. G.

Naval Ordinance Laboratory

Barnet, F. R.

Gowen, L. F.

Oak Ridge Gaseous Diffusion Plant

Jordan, R. G.

Wilcox, W. J., Jr

Oak Ridge National Laboratory

Eatherly, W. P.

Frye, J. H.

Grimes, W. R.

Harms; W. 0 .

Patriarca, $P$.

Rosenthal, M. W.

Strehlow, R. A.

Oak Ridge Y-12 Plant

Ardary, Z. L.

Bernander, N. K.

Briscoe, O.W.

Burditt, R. B.

Burkhart, L. E.

Cook, J. L.

Creech, E. T. Williams, N. W., Jr

Denny, A. (2) 
Harper, W. L. (5)

Hemphill, L. F.

Horne, O. J. (5)

Kahl, K. G.

Keith, Alvin

Kite, H. T.

Lambdin, $F$.

Larson, E. A. (5)

Marrow, G. B.

McLendon, J. D.

McWhorter, W. C.

Mitchel, G. W.

Napier, B., Jr (5)

Napier, J. M.

Overholser, L. G.

Schmitt, C. R. (5)

Schreyer, J. M.

Smith, R. D.

Smith, W. E. (10)

Tench, F.M.

Trotter, T. C.

Weathersby, W. E.

Wesley, R. L.

Yaggi, W. J./Googin, J. M.

Zocher, R. W.

$Y-12$ Central Files (10)

$Y-12$ Central Files (master copy)

$Y-12$ Central Files (route)

$Y-12$ Central Files ( $Y-12 R C)$

Paducah Gaseous Diffusion Plant

Winkel, R. A.

Penn State University

Walker, P. L. Jr

Philcu-Ford Corporation

Fossel, W. M., Jr

Poco Graphite Company

Carlson, F. C.
Quaker Oats Company-

John Stuart Research Laboratory

Brown, L. H.

Watson, D.

Raytheon Company

Pappis, J.

SAMSO (SMT/AFMI)

Hjelm, L./MAAS

SAMCO/SMYYSE

Swartz, T., Capt. (2)

Sandia-Albuquerque

Acton, R. U.

Braasch, R. H.

Butler, B. L.

Cmabai, A. J.

Frye, E. R.

Heckman, R. C.

Jeffers, S. L.

McDonald, J. E.

Peurifoy, R. L., Jr

Schmitt, W. H.

Stoller, D. M.

Sandia-Livermore

Adolphson, D. R.

Davies, L. E.

Southern Research Institute

Pears, $C$.

Space Nuclear Propulsion Office-

Albuquerque

Cully, J. C.

Hessing, $H$. 
Space Nuclear Systems Office-

Cleveland

Lombardo, S.

Thielke, N. R.

Space Nuclear Systems Office-

Washington

Scheib, W. S.

Schwenk, F. C.

Stackpole Carbon Company

Shobert, E. I.

Super-Temp Corporation

Smith, W.

The University of Tennessee

Eastham, J.F.

TRW Systems Group

Bohn, J. R.

Union Carbide Corporation,

Carbon Products Division

Browning, J. B.

Singer, $L$.

Townsend, H. N.

Union Carbide Corporation,

Chemical and Plastics Division

Shechter, L.

University of Washington

Fishbach, D. B.
US Army Materials and Mechanics

\section{Research Agency}

Scala, P.

Westinghouse Astronuclear

Corporation-Pittsburgh

Fatzer, E. G.

Holmgren, J. D.

Wright-Patterson Air Force Base

Dimiduk, R./MAYT

Forney, D./MAC (2)

Horsacky, F./MAT

Latva, J./MAAC

Minges, M./MAAS

Pratt, C./MAAS

Rowan, R. R./MAMN

Schmidt, D./MANC

In addition, this report is distributed in accordance with the category UC-4, Chemistry, as given in the "USAEC Standard Distribution Lists for Unclassified Scientific and Technical Reports", TID-4500. 


\section{ABSTRACT}

Hydrocarbon compounds derived from indene were evaluated with respect to the properties of the carbon produced on heating to temperatures in the range from 700 to $2,800^{\circ} \mathrm{C}$. These synthetic hydrocarbon compounds were polymerized by using oxidative, catalytic, and thermal methods of initiation. Polymer properties such as molecular distribution, molecular weight, viscosity, and softening point were determined. Both monomer and polymer materials were carbonized in a nitrogen atmosphere to $700-1,000^{\circ} \mathrm{C}$, and coke yields were determined. Carbon samples were subsequently fired to $1,600-2,800^{\circ} \mathrm{C}$, and the carbon properties at the respective temperatures were determined. Methods used to evaluate the carbon samples included $X$-ray diffraction and metallography, and the observed carbon properties were correlated with properties previously determined for the precursor materials. These correlations suggest various approaches to the control of properties of carbon derived from snythetic precursor materials. 
CONTENTS

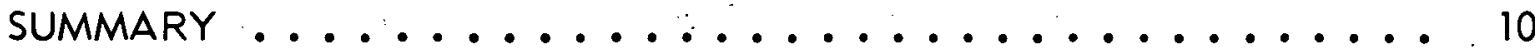

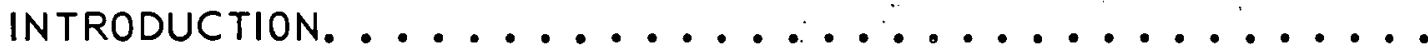

STUDY OF INDENE-DERIVED CARBONS . . . . . . . . . 15

Experimental Procedure ..................... . . 15

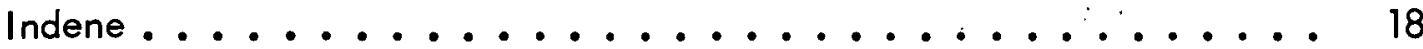

Oxidative Polymerization. .................. 18

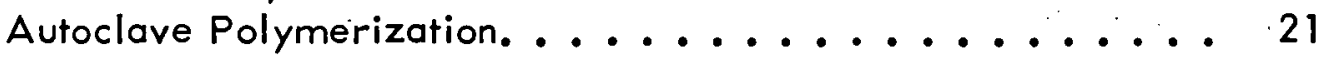

Acid Polymerization ................... 21

Vinylation of Indene and Polyindene . . . . . . . . . 27

Miscellaneous Compounds Derived from Indene and

Organic Halides. . . . . . . . . . . . . . . 28

Miscellaneous Benzofulvene Compounds . . . . . . . . . . 30

Cinnamylideneindene (CAl) ................. 35

Effect of Inorganic Constituents on the Properties of

CAl-Derived Carbon .............. 37

Autoclave Polymerization. ............... 40

Oxidative Polymerization. ................. 46

Effect of Pyromellitic Dianhydride (PMDA) on the

Properties of CAI-Derived Carbon. . . . . . . . . 50

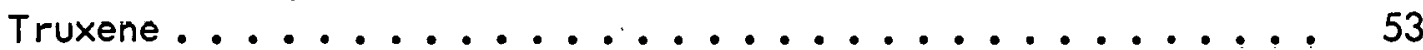

Effect of Metals on the Graphitizability of

Truxene-Derived Carbon . . . . . . . . . . . . 57

Truxene-Pyromellitic Dianhydride Mixtures. . . . . . . . 59

Isotruxene............................. 63

Properties of Carbon Derived from Isotruxene (ITX)

without a Prior Air Cure .............. 66

Properties of Carbon Derived from Isotruxene

with an Air Cure ................. 67

Properties of Isotruxene-Derived Carbon as a Function of the

Firing Temperature between 1,000 and $2,800^{\circ} \mathrm{C} \ldots \ldots 69$

Oxidative Polymerization of Isotruxene under Various

Heat-Treatment Conditions. . . . . . . . . . . . 74

Properties of Carbon Derived from Blends of Air-Cured

and Uncured Isotruxene. . . . . . . . . . . . 95

Properties of Carbon Derived from I sotruxene-Sulfur Mixtures. . 98

Properties of Carbon Derived from Isotruxene-Pyromellitic

Dianhydride Mixtures. . . . . . . . . . . . .

100 
Properties of Carbon Derived from Vinylated Derivatives

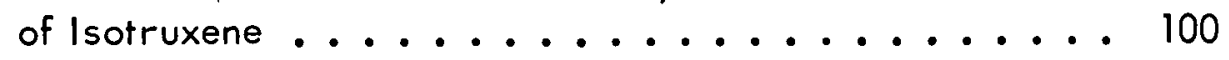

Truxene-Isotruxene Mixtures. ............... 105

Properties of Carbon Derived from Truxene-Isotruxene

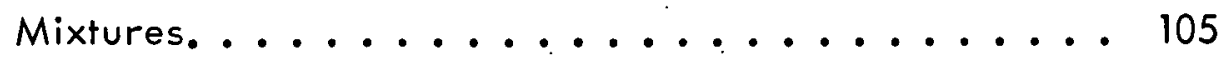

Oxidative Polymerization of Truxene-Isotruxene Mixtures . . 108

Isotruxene-Biphenyl Mixtures ........................... 114

Isotruxene-Polymerized Furfuryl Alcohol Mixtures . . . . . . . 118

Isotruxene-Truxene-Acenaphthalene (ACN) Mixtures ....... 124

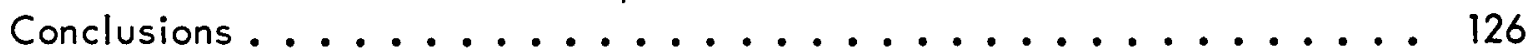

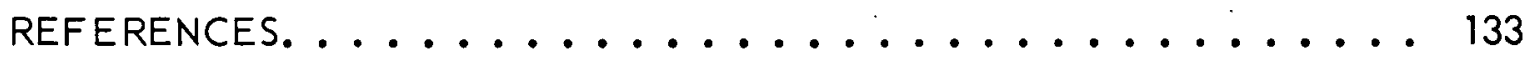

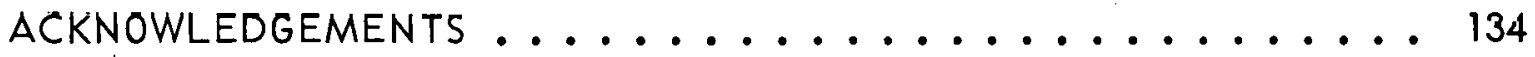




\section{SUMMARY}

The primary goal of this study was to develop synthetic carbon precursor systems that are economically feasible, reproducible, and which allow controlled modifications of the derived carbon by variations in the precursor properties and processing conditions. Such an approach depends on a knowledge of those factors which influence the properties of a derived carbon. Thus, included in this study were experiments designed to provide a correlation between the carbon properties and the molecular structure of monomer materials, polymerization methods, properties of polymer materials, and methods of carbonization. For the most part, only hydrocarbon derivatives of indene were evaluated. Of the indene compounds which were evaluated, cinnamylideneindene (CAI) and isotruxene (ITX) systems received the greatest emphasis because, currently, these systems appear to be more suitable for applications requiring carbon precursor materials. In general, the chemistry of indene affords a series of compounds with various properties which, in turn, produce a carbon with various properties.

Approaches to the control of the properties of carbon derived from indene compounds include: (1) incorporation of additives to enhance crosslinking during polymerization, and (2) combining two or more precursors which, individually, give rise to different carbon properties but which, collectively, produce a uniform carbon with properties that are a function of the composition. Data collected during this study suggest that both of these general approaches provide a degree of controlled modification of carbon properties, and should afford methods of producing carbon that can be tailored to property specifications that might be associated with a given application. 


\section{INTRODUCTION}

Advances in structural design now evident in reactor, aerospace, and related technologies are accompanied by demands for speciality forms of structural materials. One material receiving much consideration for special applications in these areas is carbon. Prior evaluations have shown that carbon can be substituted in certain applications for the more classical structural materials (such as metals, ceramics, and plastics) and can often impart more desirable material properties.

An apt description of carbon technology was stated by Mantell:

"Carbon, in its industrial applications, is a subject which is at the same time very wide and very specialized. Its ramifications are many, and its forms numerous. Its technology is as yet young, but its development in the last two decades has been so rapid as to be astounding."(1)

Properties which make carbon interesting from the standpoint of structural applications are: (1) high-temperature heat resistance, (2) resistance to chemical attack, (3) constancy of properties with time, (4) its high strength-to-density ratio, and (5) a variety of forms (such as foams and fibers) into which carbon can conveniently be made and the variety of properties that these forms can impart in structural applications.

Included in a general discussion of carbon properties would be those properties characterizing the diamond structure, ${ }^{(2)}$ those characterizing the graphite structures, (3) and those characterizing a series of carbons with varying degrees of graphiticity, beginning with amorphous (4) or. "glassy" carbons and increasing in crystallinity as the theoretical graphite structure is approached. In addition to diamond and graphite, other allotropic forms of carbon have been alluded to in the literature. $(5-7)$ These include "white carbon" and linear "carbon polymers".

Efforts in this study at the Oak Ridge $Y-12$ Plant(a) are directed toward graphitic carbons, and more specifically toward possible correlations between the precursor properties and the properties of a derived carbon.

Carbon properties will be determined by the properties associated with a precursor at temperatures just below that required to "carbonize" the organic

(a) Operated by the Union Carbide Corporation's Nuclear Division for the US Atomic Energy Commission. 
material. In turn, the properties of a precursor polymer at subcarbonization temperatures will be dependent on the properties of the monomer and the conditions under which the polymerization was effected. To be specific, molecular structures of monomeric materials and reaction mechanisms during polymerization largely determine the properties of a derived carbon since, under constant reaction conditions, these two factors will determine the degrees of molecular freedom, reaction rates, bonding, viscosities, and other polymer properties which influence the properties of a derived carbon. Thus, variability in carbon properties can result from: (1) variations in the structure of the monomeric materials, (2) changes in the composition of mixtures of monomeric materials, and (3) variations in the reaction mechanisms by which monomeric materials are converted to polymeric, and, subsequently, carbonaceous materials. Changes in the reaction mechanisms can be affected by polymerization conditions (such as temperature, pressure, heating rates, and atmosphere) and the presence of impurities, both inherent and induced. Thus, fabrication of speciality forms of carbon requires a stringent control over the process variables, and demands that greater attention be given to certification and control of the raw materials that are used as precursors to carbon.

How are graphitic properties affected by molecular structures and reaction mechanisms? Familiarity with the planar aromatic structure that characterizes the unit cell of a graphite crystal would suggest that any precursor aspiring to be graphitic must be able to assume this type of structure. Thus, the transition from an organic hydrocarbon structure to a graphitic structure would involve such factors as bond cleavage, molecular rearrangements, cyclization, aromatization, and dehydrogenation. In turn, factors inhibiting these processes from occurring in a prescribed order and at prescribed rates would favor the formation of a nongraphitic carbon, and varying degrees of inhibition would result in carbon with varying graphiticity. Reactive materials that "thermoset" into highly crosslinked polymers that either do not fuse prior to pyrolysis or remain in a highly viscous state do not tend to rearrange or reorient due to reduced degrees of molecular freedom, and, thus, do not tend to form graphitic carbon. On the other hand, thermoplastic materials or materials with a. low degree of crosslinking allow viscosities that are conducive to molecular rearrangement and reorientation, and would tend to form graphitic carbons unless stable nonplanar intermediates are formed.

Carbon is, truly, a unique element due to its inherent atomic structure which allows it to combine with itself repeatedly to form an almost innumerable list of organic compounds. Though all can be converted to carbon, certain factors preclude the use of some compounds and limit the practicality of others. The specific application will largely dictate the type of carbon and 
the fabrication method to be used. Other general factors to consider in selecting a precursor material are: (1) processability; (2) weight, volume, and strength yield on carbonization; (3) properties in the temperature range from 1,000 to $3,000^{\circ} \mathrm{C} ;(4)$ reproducibility; and (5) economics.

In the past, a lack of reproducibility in precursor materials has aided in keeping carbon technology in the realm of a "black art". Natural sources of precursor materials, having different chronologies, and having been formed from various organic materials under various conditions, do not lend themselves to reproducibility. This fact prompted an investigation of synthetic sources of carbon for certain filler and binder applications. In choosing a precursor for any application, the prime concern is the reproducibility of specified properties. However, in choosing a precursor for binder application, the physical properties of the precursor must also be considered; namely, the precursor should: (1) be fluid at the processing temperatures, (2) wet the substrate materials, (3) not release or induce stresses in such a manner that undesirable distortion occurs in a composite product, and (4) yield carbon with mechanical properties that are compatible with the substrate material.

This report describes an evaluation of the various precursor materials derived fron indene $\left(\mathrm{C}_{9} \mathrm{H}_{8}\right)$. Synthesis and characterization of these materials were described in a prior report. (8) The molecular structure of indene is:

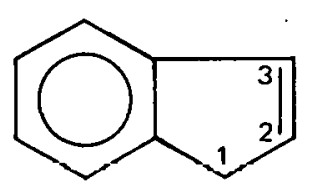

As is apparent, the indene structure incorporates a five-member ring containing both olefinic-type unsaturation and a reactive methylene site. Elimination of either of these functional groups reduces the reactivity and yields compounds which are much less versatile as precursor sources:

In addition to indene, other indene-type analogs in which the methylene or olefinic groups are eliminated may be represented by acenaphthalene and fluorene, respectively: 


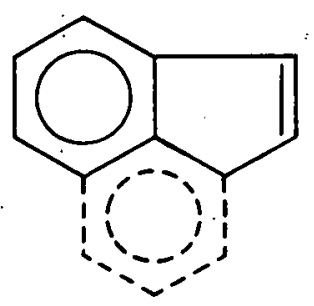

acenaphthalene

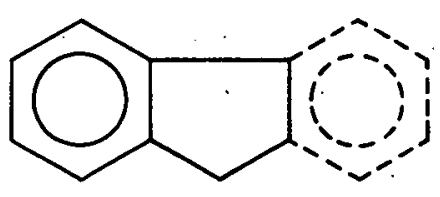

fluorene

A brief discussion of the latter materials is also included in this report. 


\section{STUDY OF INDENE-DERIVED CARBONS}

\section{EXPERIMENTAL PROCEDURE}

The procedural approach used in evaluating synthetic precursor materials may be outlined as follows:

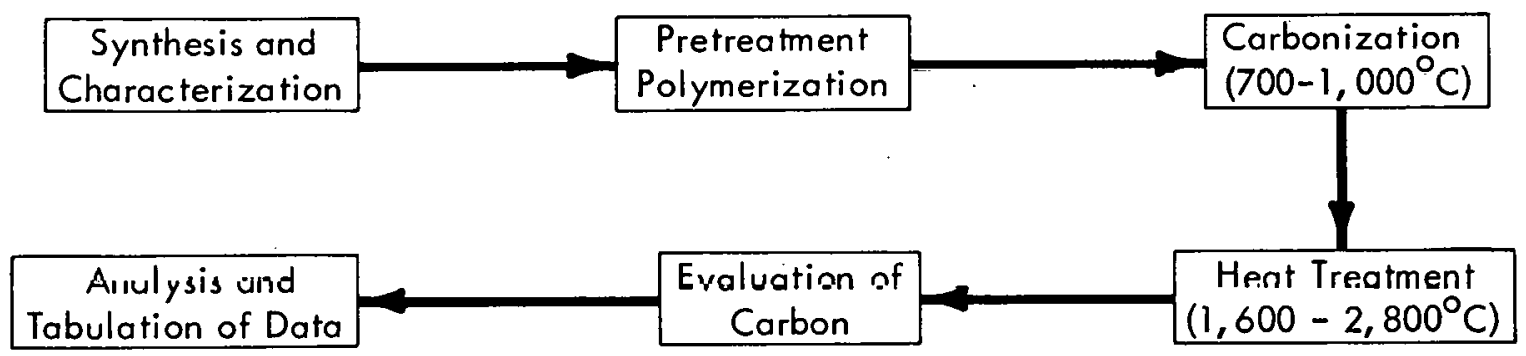

The effects of various pretreatment conditions on coke yield and carbon properties were evaluated. Pretreatment, if any, consisted of either thermal or radical-induced polymerization in either the presence or absence of oxygen. Thermal polymerization procedures consisted of: (1) heat treatment in air to $250^{\circ} \mathrm{C}$ using a programmed heating cycle covering a period of approximately 50 hours; (2) heating isothermally at temperatures in the range from 200 to $350^{\circ} \mathrm{C}$, either in the presence or absence of oxygen; (3) heating isothermally in an autoclave at temperatures and pressures of $200-350^{\circ} \mathrm{C}$ and $300-800$ psi, respectively; and (4) heating isothermally at temperatures in the range of $200-300^{\circ} \mathrm{C}$ with oxygen gas bubbling through the molten material at a controlled rate. In addition to oxygen, the effects of other additives, such as sulfur and pyromellitic dianhydride, were determined. Characterization of polymeric intermediates involved the use of gel permeation chromatography (GPC) and molecular weight analyses (via vapor pressure osmometry).

Carbonization consisted of heating monomeric or polymeric materials to $700-1,000^{\circ} \mathrm{C}$ in an inert gas atmosphere. Usually, this procedure was rate controlled and required approximately 60 hours. Coke yields were calculated after the $700-1,000^{\circ} \mathrm{C}$ carbonization step, and weight losses incurred during polymerization procedures prior to carbonization were included in calculating the total weight loss. Volume yields were calculated using the following equations based on coke yield and mass-density-volume relationships:

$$
\text { Percent Volume Yield }=\left(\frac{\text { Volume }_{\text {carbon }}}{\text { Volume }_{\text {precursor }}}\right) \times 100,
$$




$$
\begin{aligned}
& \text { Volume }=\text { mass } / \text { density, } \\
& \text { Volume }_{\text {carbon }}=V_{c}=(\mathrm{m} / \mathrm{d})_{\mathrm{c}} \text {, } \\
& \text { Volume }_{\text {precursor }}=V_{p}=(\mathrm{m} / \mathrm{d})_{p} \text {; } \\
& \text { Percent Volume Yield }=\left[\frac{(\mathrm{m} / \mathrm{d})_{c}}{(\mathrm{~m} / \mathrm{d})_{\mathrm{p}}}\right] \times 100, \\
& m_{c}=m_{p} \times \text { percent coke yield/100, } \\
& \text { Percent Volume Yield }=\left[\frac{\frac{m_{p} \text { percent coke yield }}{d_{c} \times 100}}{(m / d)_{p}}\right] \times 100 \text {, and } \\
& \text { Percent Volume Yield }=\text { Percent Coke Yield }\left(\frac{d_{p}}{d_{c}}\right) \text {. }
\end{aligned}
$$

Theoretical curves showing the relationships between volume yield, coke yield, and $d_{p} / d_{c}$ ratios are given in Figures 1 and 2 . Thus, volume yields can be read directly from the graphs if coke yields and density data are known.

After carbonization, samples were fired to $1,600-2,800^{\circ} \mathrm{C}$ and were evalvated by metallography (using sensitive-tint techniques) and by $X$-ray diffraction. Interlayer spacings were calculated from $X$-ray diffraction data using the methods described by Ruland. ${ }^{(9)}$.The degree of graphiticity of carbon samples was also expressed in terms of a $\mathrm{g}$ factor, defined as follows by Maire and Mering: (10)

$$
d_{002}=(g) 3.355+(1-g) 3.44 \text {. }
$$

Various correlations between precursor properties, polymerization conditions, and carbon properties were established, and are presented in the sections that follow. 


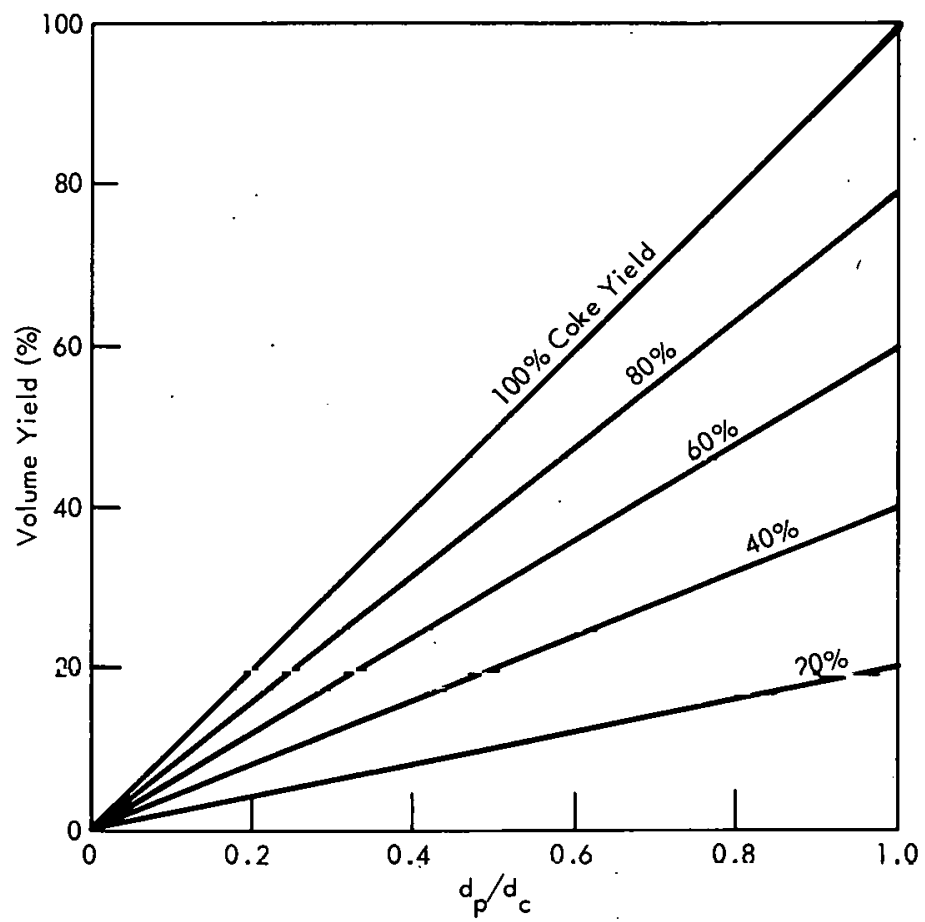

Figure 1. THEORETICAL CURVES SHOWING VOLUME YIELD AS A FUNCTION OF THE PRECURSOR/CARBON DENSITY RATIOS AT VARIOUS COKE-YIELD VALUES.

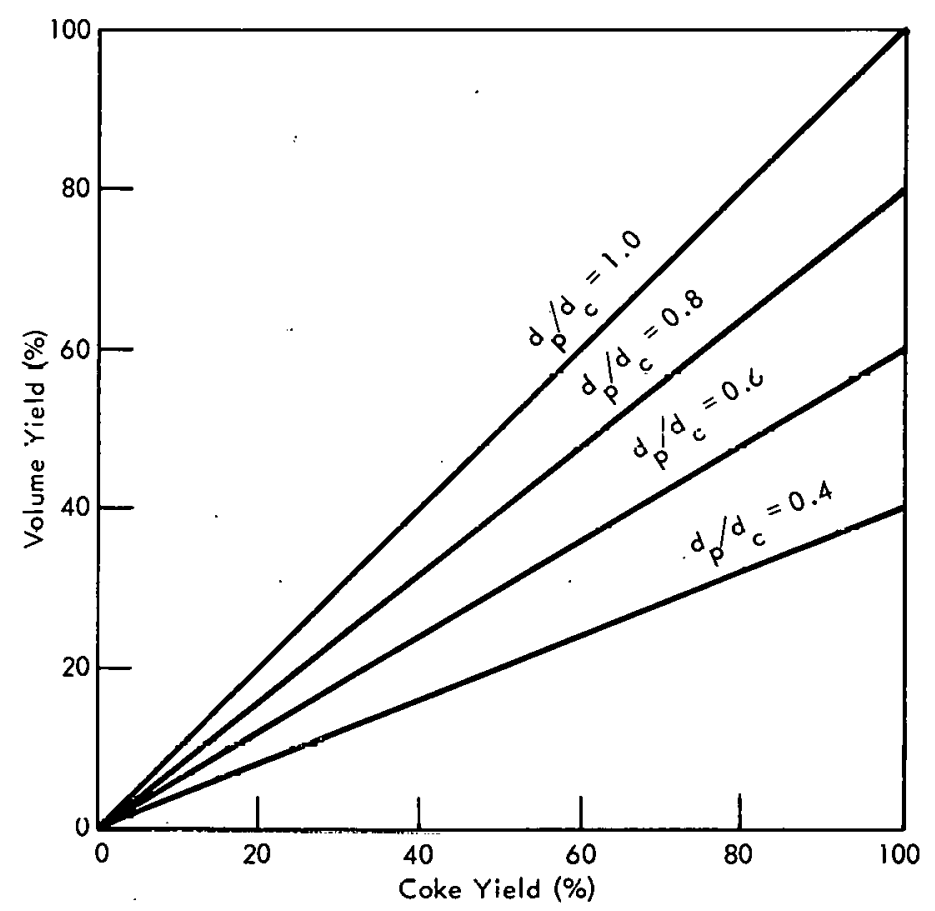

Figure 2. THEORETICAL CURVES SHOWING VOLUME YIELD AS A FUNCTION OF THE COKE YIELD FOR VARIOUS PRECURSOR/CAR BON DENSITY RATIOS. 
Indene

Indene $\left(\mathrm{C}_{9} \mathrm{H}_{8}\right)$ represents the primary material from which various precursor materials were derived, but is itself not a desirable precursor to carbon because of low coke yields $(1-5 \%)$ when pyrolyzed in open containers at or near pressures of one atmosphere.

Somewhat higher coke yields can be obtained from polymeric forms of indene. The following subsections discuss the various methods of polymerization that were evaluated.

Oxidative Polymerization - Polymers of indene that are formed under oxidation conditions have higher coke yields than the monomer and produce a small-grain, isotropic graphite. Oxidative polymerization was carried out by heating indene under reflux with constant agitation and with oxygen gas bubbling continuously through the fluid sample. The apparatus used in this experiment can be seen in Figure 3. Modifications included the addition of a reflux condenser connected to the heating vessel by a trap to remove water from the condensate. Samples of the heat-treated indene were taken periodically for evaluation and characterization. The resulting data are summarized in Table 1.

As polymerization proceeded, the pot temperature was allowed to increase with the increasing reflux temperature which tended to level out at $235^{\circ} \mathrm{C}$ after approximately 85 hours. As indicated by other data recorded in Table 1, measured properties tended to exhibit maxima or minima for reflux times

Table 1

PROPERTIES OF CARBON DERIVED FROM INDENE THAT WAS HEAT TREATED IN THE PRESENCE OF OXYGEN GAS

\begin{tabular}{|c|c|c|c|c|c|c|c|c|}
\hline \multirow[b]{3}{*}{$\begin{array}{c}\text { Sample } \\
\text { Number }(1)\end{array}$} & \multicolumn{4}{|c|}{ Polymerization } & \multicolumn{4}{|c|}{ Carbonization } \\
\hline & $\begin{array}{c}\text { Heat } \\
\text { Treatment }\end{array}$ & & Average & Oxygen & $\begin{array}{c}\text { Coke Yield } \\
\text { After }\end{array}$ & Propert & s After 2, & ${ }^{\circ} \mathrm{C}$ \\
\hline & $\begin{array}{l}\text { Time } \\
\text { (hrs) }\end{array}$ & $\begin{array}{c}\text { Temperature } \\
\left({ }^{\circ} \mathrm{C}\right)\end{array}$ & $\begin{array}{c}\text { Molecular } \\
\text { Weight }\end{array}$ & $\begin{array}{c}\text { Content (2) } \\
(\%)\end{array}$ & $\begin{array}{c}1,000^{\circ} \mathrm{C} \\
(\%)\end{array}$ & $\begin{array}{l}\mathrm{d} 004 \\
(\mathrm{~A})\end{array}$ & g factor & $\begin{array}{l}L_{c} \\
\text { (A) }\end{array}$ \\
\hline $\mathrm{A} 2$ & .0 & - & 139 & 0.16 & 1.0 & 1.6920 & 0.659 & 94 \\
\hline B & 24 & 163 & 203 & - & 6 & 1.6917 & 0.671 & 88 \\
\hline C & 48 & 183 & 290 & - & 12 & 1.6934 & 0.624 & 94 \\
\hline$D$ & 72 & 214 & 417 & 1.48 & 15 & 1.6958 & 0.565 & 77 \\
\hline$F$ & 10 & 235 & 481 & $1: 31$ & 13 & 1.0923 & 0.647 & 89 \\
\hline G & 130 & 235 & 427 & 1.13 & 11.0 & 1.6903 & 0.694 & 97 \\
\hline
\end{tabular}

(1) The indene was heated under reflux conditions with oxygen gas bubbling continuously through the reaction pot at $84 \mathrm{cc} / \mathrm{min}$. Samples were taken periodically for evaluation.

(2) Determined by neutron activation. 


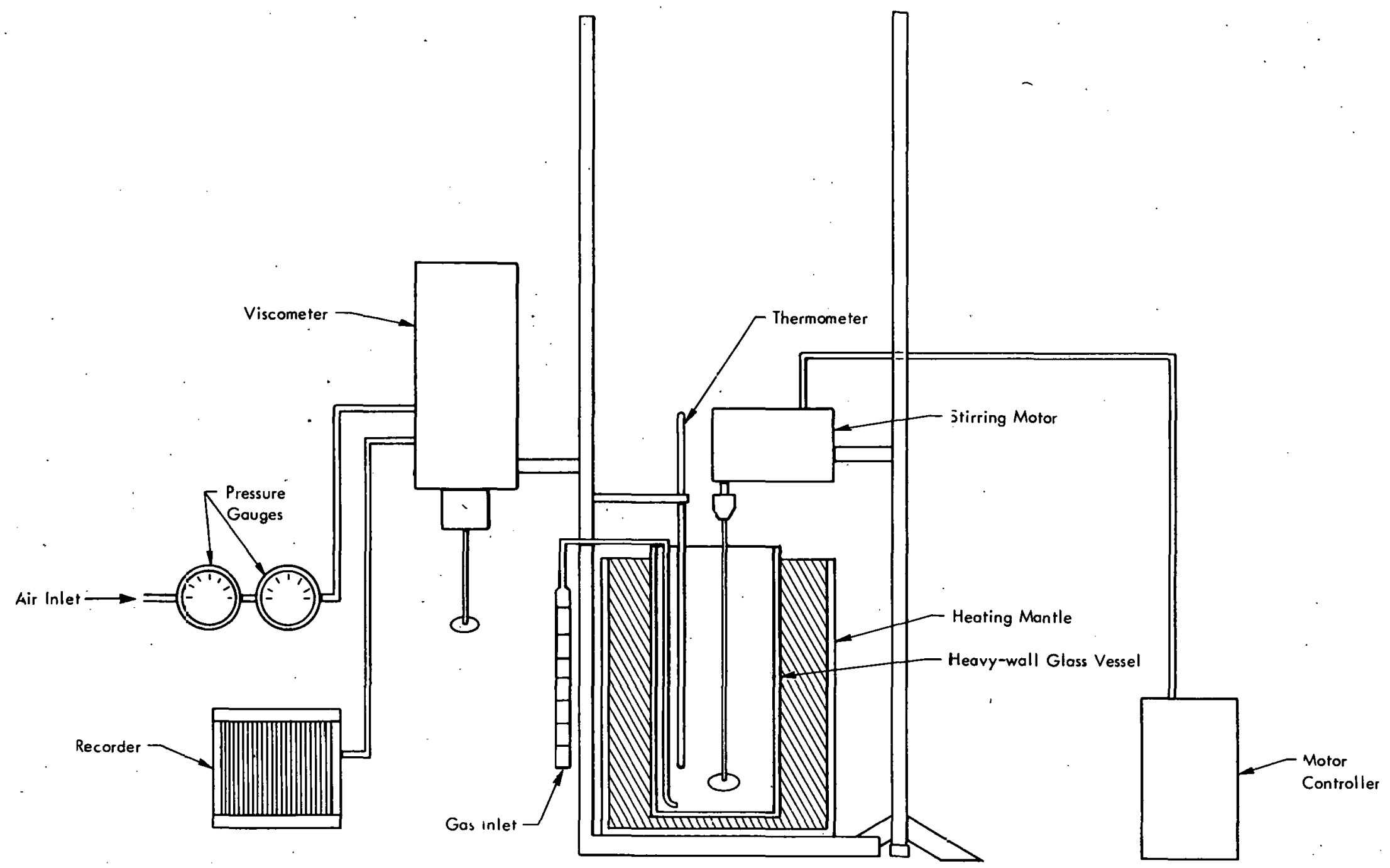

Figure 3. APPARATUS USED FOR THE OXIDATIVE POLYMERIZATION OF INDENE -DER VED HYDROCARBONS. 
corresponding to approximately 85 hours. This. fact is apparent in Figure 4 which shows reflux temperatures, average molecular weights, coke yields; and $\mathrm{g}$ factors as functions of the heating time. Also, the oxygen uptake passed through a maximum. These transitions indicate degradation of the polymeric species as the pot temperature approached $235^{\circ} \mathrm{C}$. Oxidation during the heat treatment was apparent not only from the observed increases in the oxygen content of the precursor, but also by the continuous formation of water. The

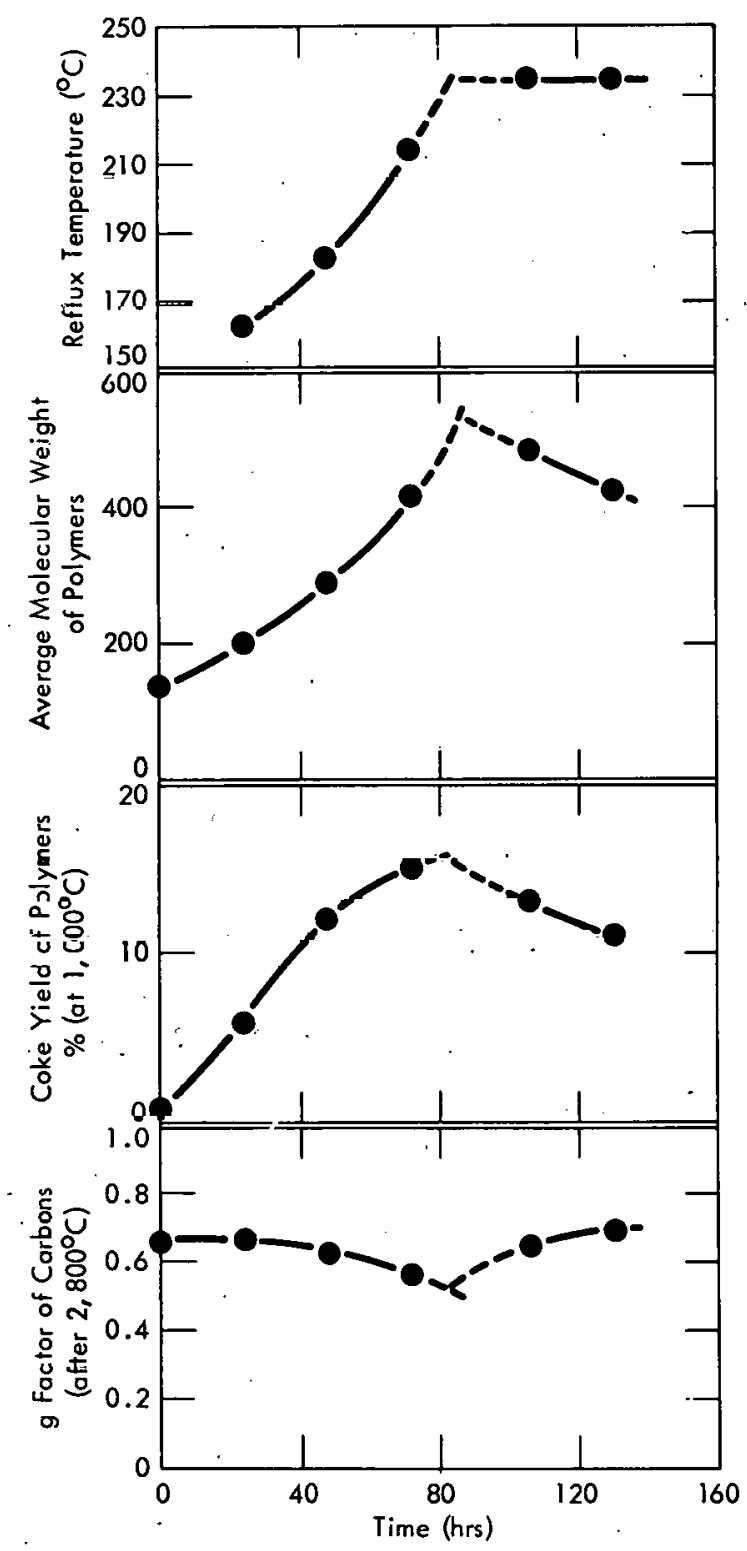

Figure 4. REFLUX TEMPERATURE, AVERAGE MOLECULAR WEIGHT, COKE YIELD, AND g FACTOR AS FUNCTIONS OF THE HEAT-TREATMENT TIME FOR SAMPLES OF INDENE THAT WERE OXIDATIVELY POLYMERIZED. 
decrease in oxygen content at $235^{\circ} \mathrm{C}$ denoted an increased tendency for combined oxygen to form water. It was of interest to note that samples having higher oxygen contents also have higher coke yields, but a corresponding lower degree of graphiticity. These data suggest a correlation between the oxygen content and the degree of crosslinking in the polymer.

GPC scans showing the change in molecular distribution with heat-treatment time are presented in Figure 5. The monomer content was observed to decrease with time, and existed as only a minor constituent after approximately 106 hours. Comparison of scans corresponding to 106 and 130-hour periods shows a shift to lower molecular-weight species with a significant increase in dimer content, and is in support of molecular weight data indicating a degradation on heating at $235^{\circ} \mathrm{C}$.

Carbon derived from these polymeric indene materials exhibited microstructures with relatively fine-grain textures, as noted in Figure 6. The minimum in graphiticity indicated in Figure 4 supports the microstructural changes shown in Figure 6 .

Autoclave Polymerization - Indene readily polymerizes when heated under pressure to temperatures at or above $175^{\circ} \mathrm{C}$. This change was evident for samples of indene that were heated for six hours at a pressure of 500 psi, and at temperatures of 175,200 , and $225^{\circ} \mathrm{C}$. As indicated by the data in Table 2, an increase in the autoclave temperature from 175 to $200^{\circ} \mathrm{C}$ has a pronounced effect on the degree of polymerization and resulting polymer properties. With the exception of a considerable increase in viscosity, little change was noted in the properties of the 200 and $225^{\circ} \mathrm{C}$ products. The change in molecular distribution with autoclave temperature is emphasized in Figure 7. As discussed in a prior report, autoclave polymerization of indene at temperatures above $200^{\circ} \mathrm{C}$ results in a partial conversion to truxene-isotruxene mixtures. (8) Some granular crystals were apparent in the 200 and $225^{\circ} \mathrm{C}$ samples, and could result in an apparent viscosity somewhat higher than represented by the noncrystalline phase. Properties of carbon derived from autoclave-produced mixtures of truxene and isotruxene will be discussed later (Page 105).

Acid Polymerization - Indene is quite sensitive to acid catalysts and readily polymerizes in their presence to produce much higher-molecular-weight polymers than were obtained by thermal polymerization. Whereas, thermal polymerization tends to promote condensation to cyclic or polynuclear species, an acid catalyst promotes largely the formation of linear polymers. The coke yield data listed in Table 3 show the effect of variation in catalyst, polymerization conditions, and cure conditions. In the first place, use of tin(IV) chloride 


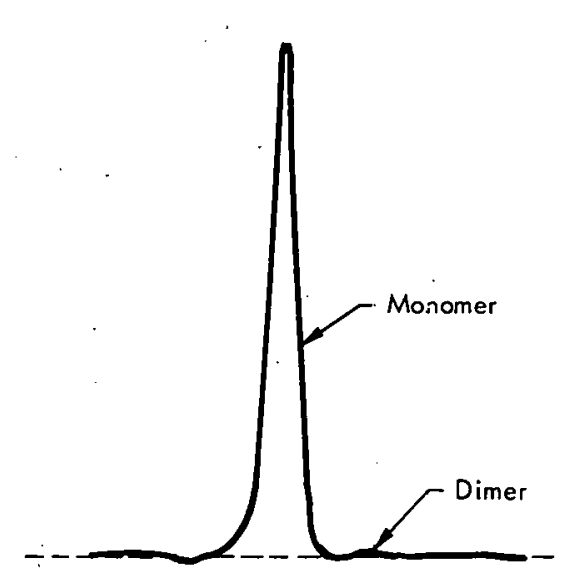

(a) 0 Hours (1X)

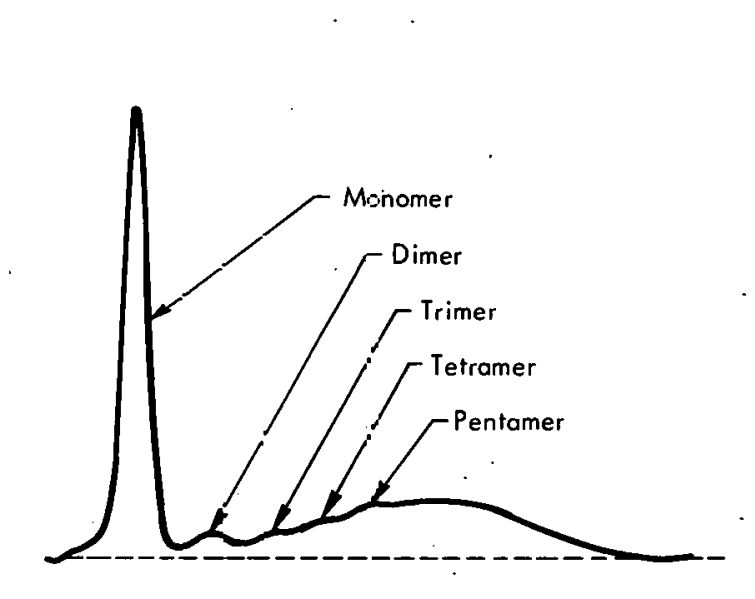

(b) 24 Hours (ax)

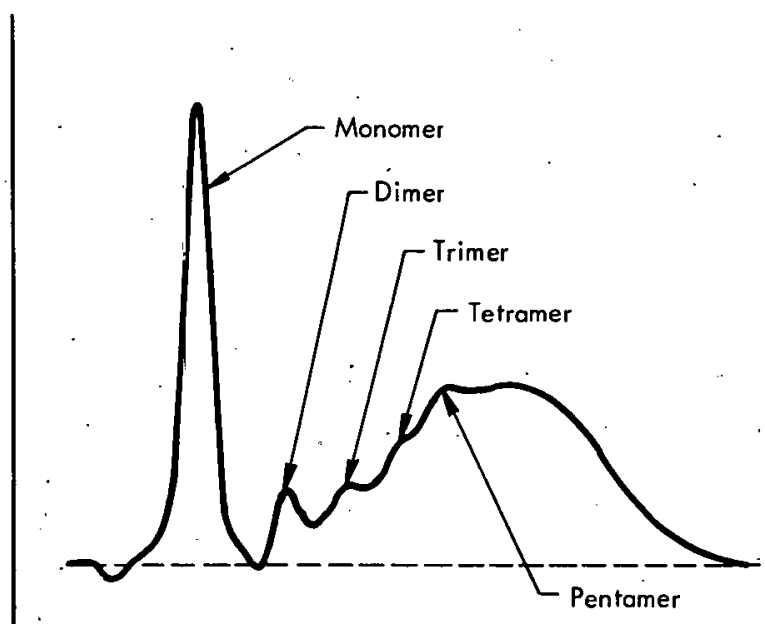

(c) 48 Hours ( $4 X$ )

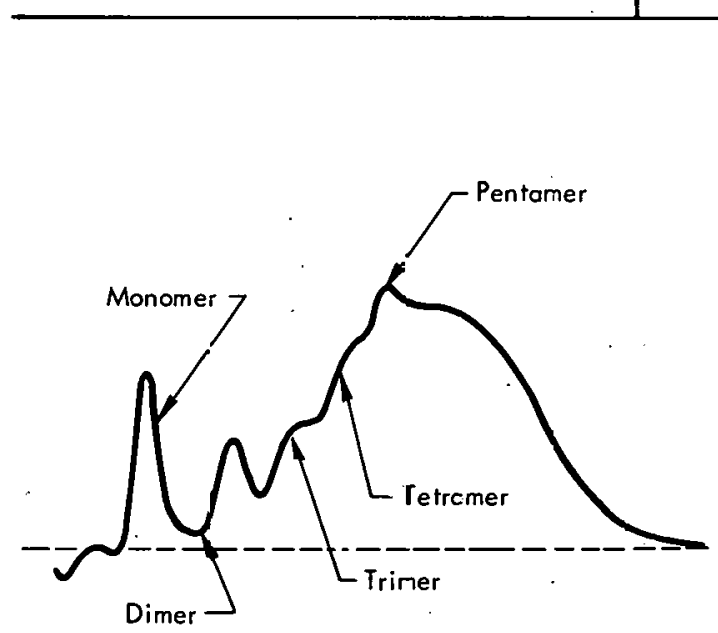

(d) 72 Hours ( $4 X$ )
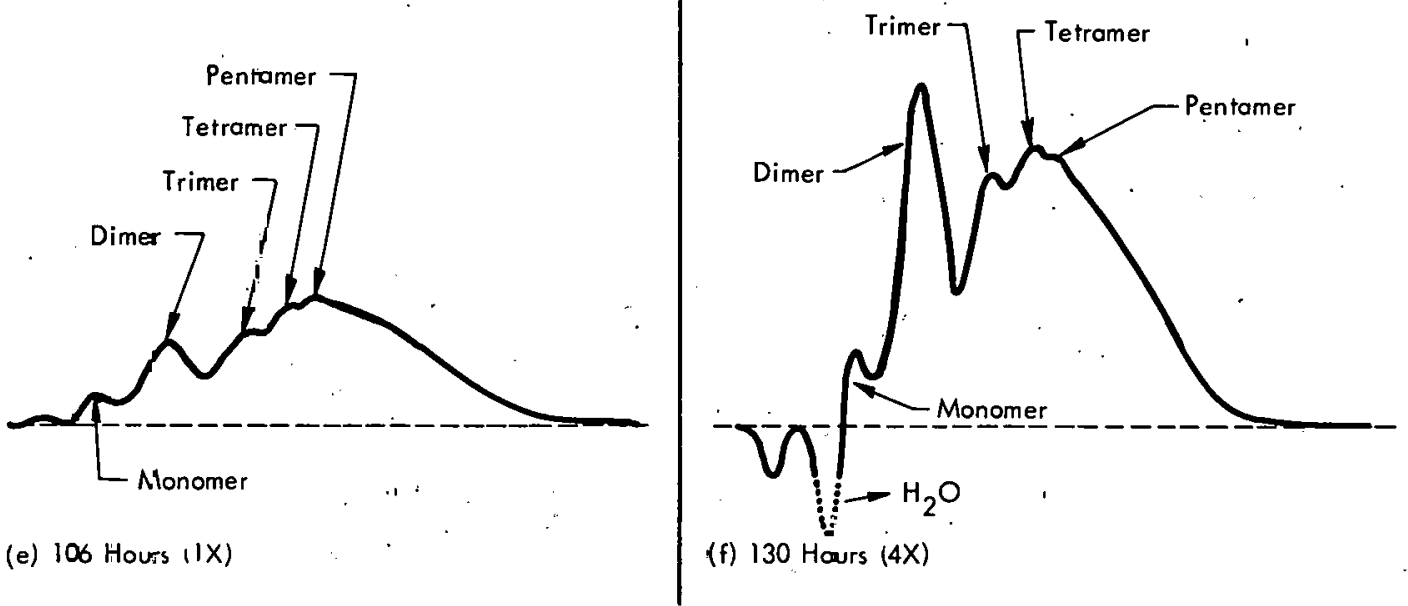

(f) 130 Hours (4X)

Figure 5. GEL PERMEATION CHROMATOGRAPHY SCANS jHOWNG THE MOLECULAR DISTRIBUTION OF INDENE. DURING OXIDATIVE POLYMERIZATION. 

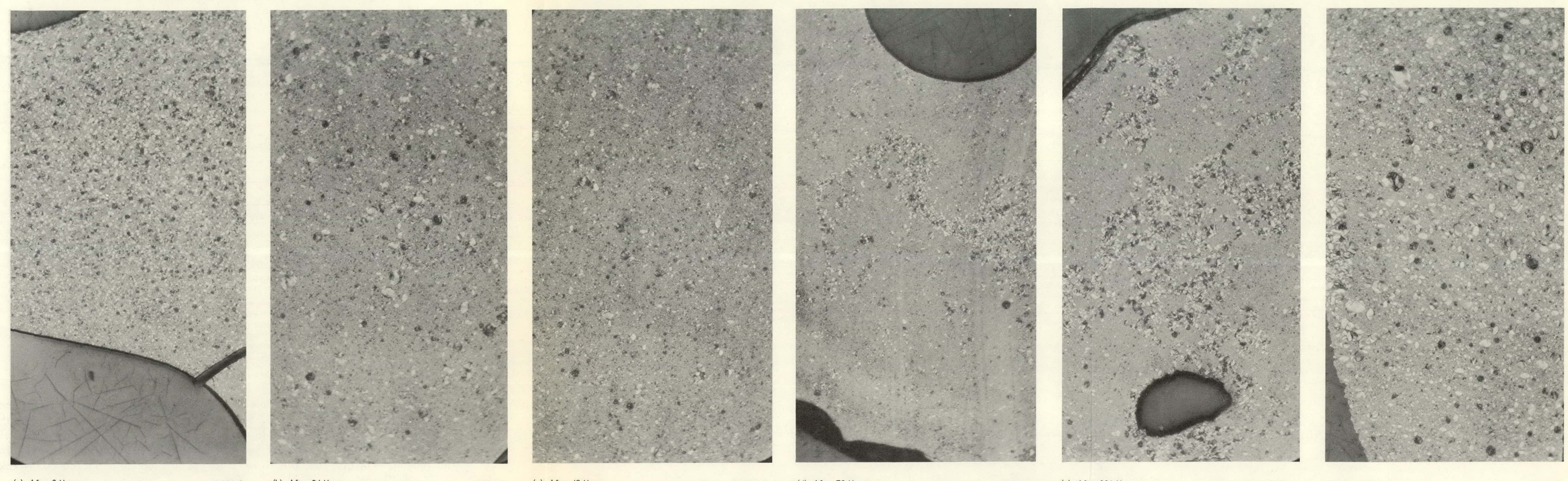

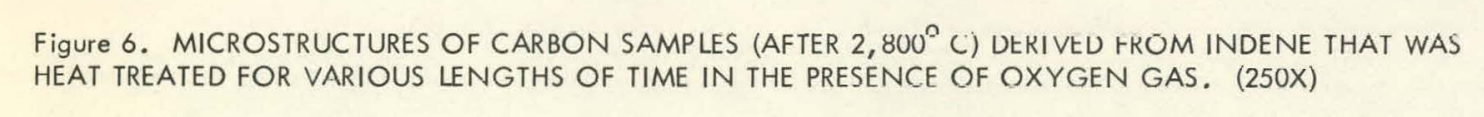


Table 2

AUTOCLAVE POLYMERIZATION OF INDENE

\begin{tabular}{ccccc}
\hline Sample $(1)$ & $\begin{array}{c}\text { Autoclave } \\
\text { Temperature } \\
\left({ }^{\circ} \mathrm{C}\right)\end{array}$ & $\begin{array}{c}\text { Average } \\
\text { Molecular } \\
\text { Weight }\end{array}$ & $\begin{array}{c}\text { Monomer } \\
\text { Content }(2) \\
(\%)\end{array}$ & $\begin{array}{c}\text { Viscosity, } \\
\text { at } 25^{\circ} \mathrm{C} \\
(\mathrm{cp})\end{array}$ \\
\hline A & 175 & 196 & 48 & 56 \\
B & 200 & 281 & 13 & $1.6 \times 10^{4(3)}$ \\
C & 225 & 289 & 9 & $5.4 \times 10^{6}(3)$ \\
\hline
\end{tabular}

(1) One-kilogram samples were heated for six hours under pressures of $\sim 500 \mathrm{psi}$.

(2) Estimated from GPC scans.

(3) These samples were somewhat granular due to the formation and crystallization of small quantities of truxene and isotruxene.

Table 3

PROPERTIES OF CARBON DERIVED FROM POLYINDENE

\begin{tabular}{|c|c|c|c|c|c|c|}
\hline \multirow[b]{2}{*}{$\begin{array}{l}\text { Sample } \\
\text { Number }\end{array}$} & \multirow{2}{*}{$\begin{array}{l}\text { Average } \\
\text { Molecular } \\
\text { Weight }\end{array}$} & \multirow{2}{*}{\multicolumn{2}{|c|}{$\begin{array}{c}\text { Coke Yield } \\
\text { After } \\
1,000^{\circ} \mathrm{C} \\
(\%)\end{array}$}} & \multicolumn{3}{|c|}{ Properties After $2,800^{\circ} \mathrm{C}$} \\
\hline & & & & $\begin{array}{c}\text { d } 0044 \\
(A)\end{array}$ & $\mathrm{g}$ factor & $\begin{array}{l}L_{c} \\
(A)\end{array}$ \\
\hline $11-23-70 A$ & $1,619(2)$ & No & 5 & 1.6923 & 0.647 & 90 \\
\hline $11-24-70 A$ & $1,026(3)$ & No & 15 & 1.6834 & 0.870 & 208 \\
\hline$E-9-7$ & $803(4)$ & No & 10 & - & - & - \\
\hline$E-9-1$ & $2,376(3)$ & No & 14 & - & - & - \\
\hline$E-9-2$ & $2,376(3)$ & No & 15 & - & - & - \\
\hline$E-9-2$ & $2,376(3)$ & Yes & 27 & - & - & - \\
\hline
\end{tabular}

(1) Air cure consisted of heating in a programmed cycle to $250^{\circ} \mathrm{C}$.

(2) Indene polymerized by adding the tin chloride-benzene solution dropwise into the indene-benzene solution.

(3) Indene polymerized by dropping the indene-benzene solution into the tin chloride-benzene solution.

(4) Indene polymerized by dropping the indene-benzene solution into the titanium chloride-benzene solution.

as a catalyst produced higher-molecular-weight and higher-coke-yield polymers than did titanium(IV) chloride. Secondly, the slow addition of indene to the catalytic solution resulted in lower-molecular-weight but higher-coke-yield polymers than those produced by the slow addition of the catalytic solution to indene. I hirdly, an air cure prior to carbonization increased the coke yield significantly.

Properties of carbon derived from two polymer samples that were produced using tin chloride as the catalyst (but by different polymerization modes) may be compared by the data in Table 3 , and from the microstructures in Figure 8. A decided difference in graphiticity and grain texture results by reversing the order of reagent addition during the polymerization step. No characterization of polymer structures or polymerization mechanisms was attempted. 


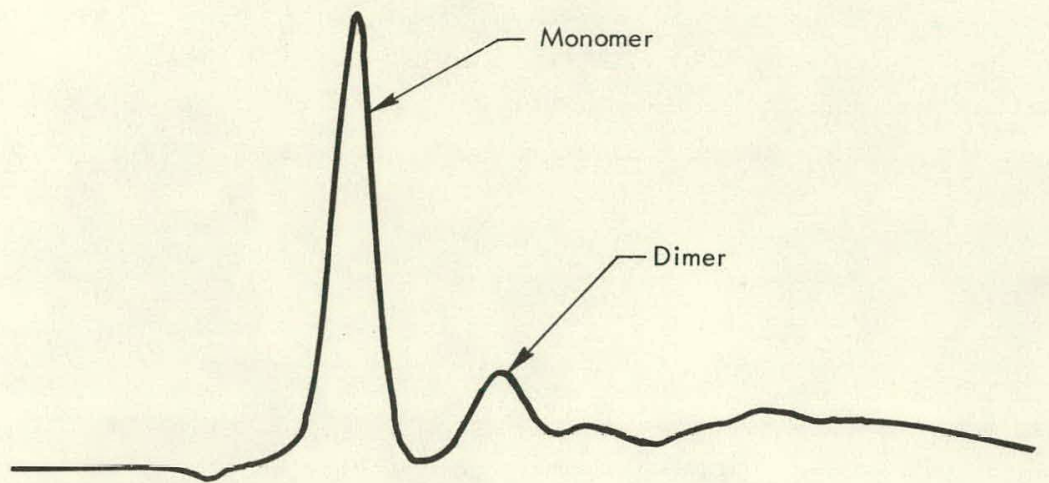

(a) $\operatorname{At} 175^{\circ} \mathrm{C}(\mathrm{IX})$

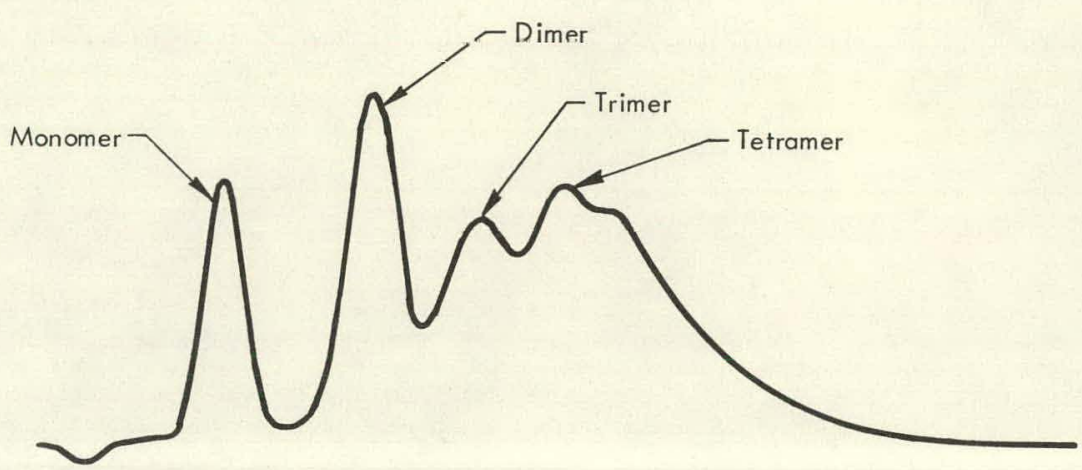

(b) At $200^{\circ} \mathrm{C}(2 \mathrm{X})$

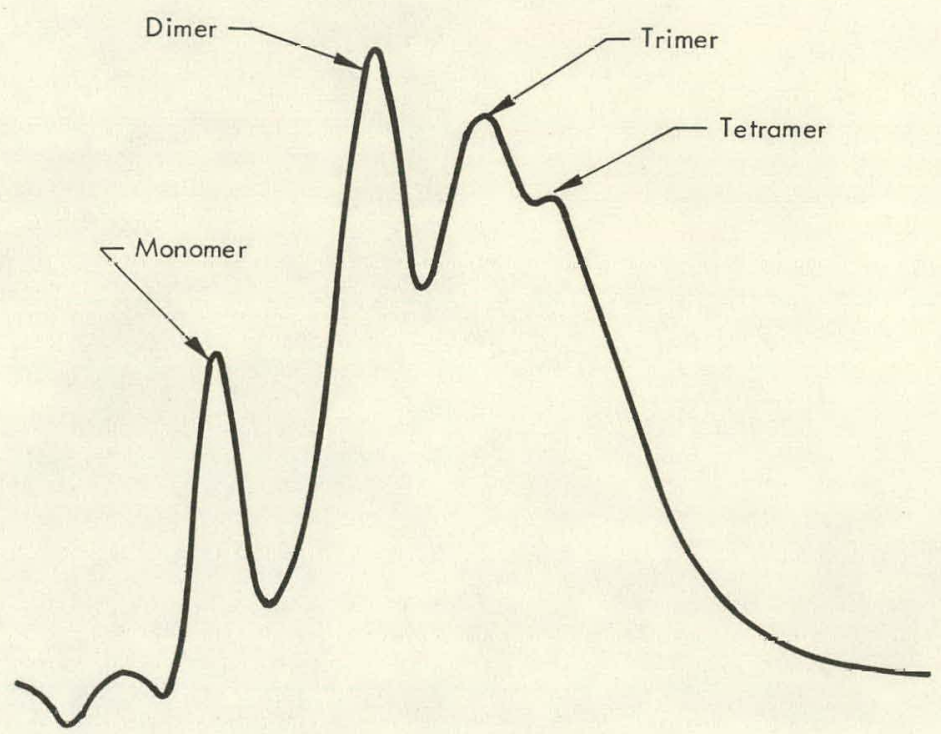

(c) At $225^{\circ} \mathrm{C}(4 \mathrm{X})$

Figure 7. GEL PERMEATION CHROMATOGRAPHY SCANS SHOWING THE MOLECULAR DISTRIBUTION OF INDENE AFTER AUTOCLAVE POLYMERIZATION. 

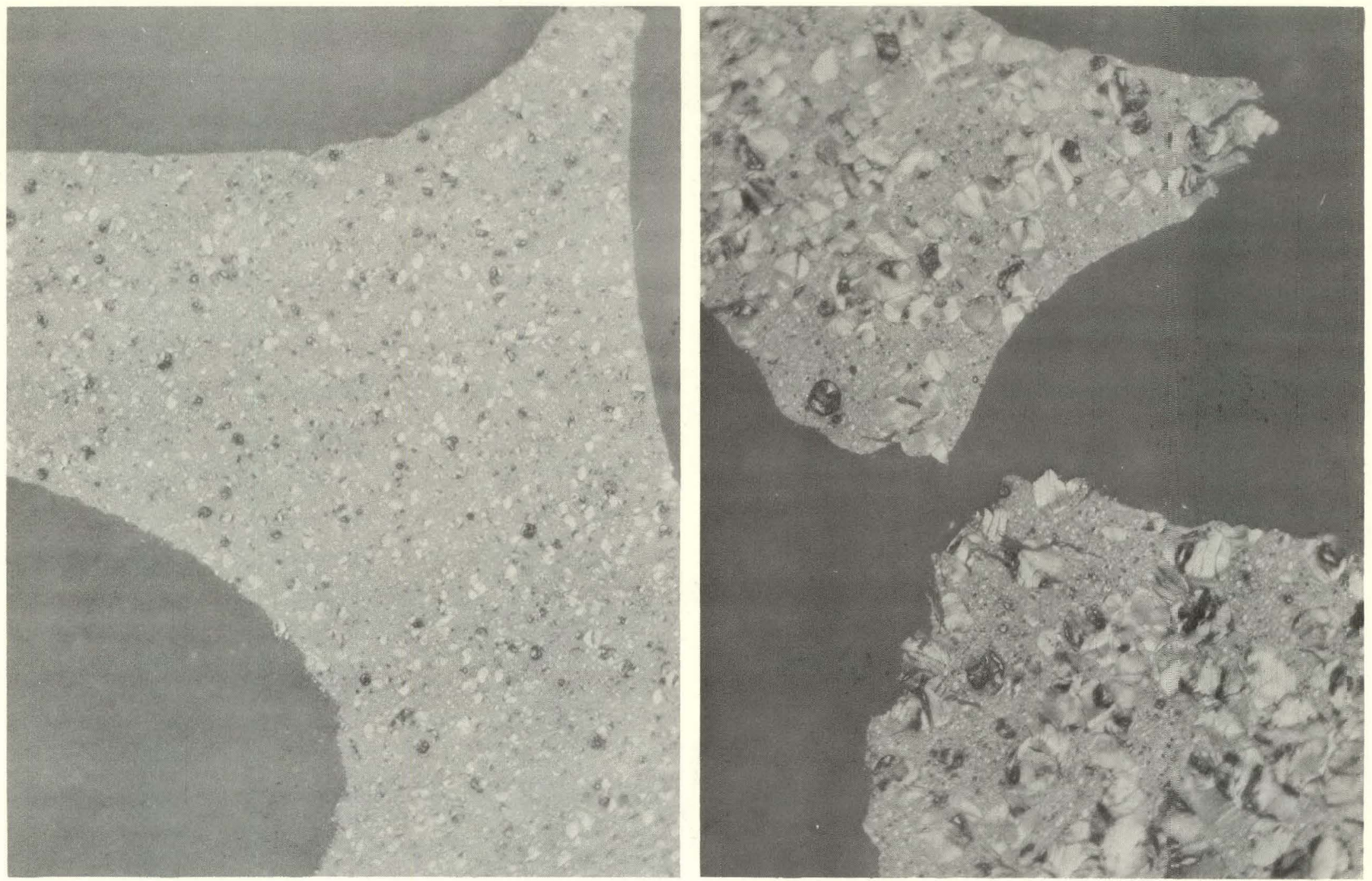

(a) Batch $11-23-70 \mathrm{~A}$

G180-3 (b) Batch 11-24-70A

G180-5

Figure 8. MICROSTRUCTURE OF CARBON SAMPLES (AFTER 2, $800^{\circ} \mathrm{C}$ ) DERIVED FROM POLYINDENE, AS FORMED, BY USING DIFFERENT POLYMERIZATION METHODS. (Refer to Table 3; 250X) 
Vinylation of Indene and Polyindene - The reaction of acetylene with hydrocarbon materials containing active hydrogen can introduce vinyl groups into the molecule and thus induce crosslinking. $(8,11)$ Using this approach, vinyl groups were incorporated in indene and polyindene structures by heating at approximately $200^{\circ} \mathrm{C}$ under acetylene pressure. As depicted in the equation that follows, this addition will be largely at the methylene site of the indene molecule.

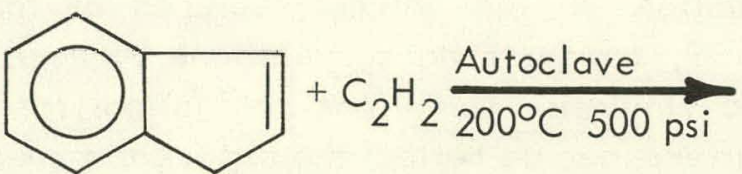

indene

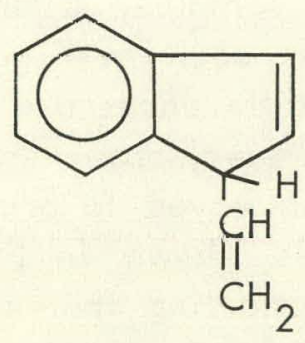

1-vinylindene

Data obtained for the various vinylated derivatives are listed in Table 4. The most striking thing about the data is the apparent lack of correlation between polymer molecular weights and coke yields. Such differences indicate the different modes of polymerization due to differences in the starting materials and reaction conditions. For example, monomeric indene samples were polymerized in the presence of acetylene at $220^{\circ} \mathrm{C}$ to produce lowmolecular-weight materials $(300-400)$ with high coke yields $(25-30 \%)$ relative to those observed for indene and polyindene (see Table 3). Vinylation

Table 4

PROPERTIES OF CARBON DERIVED FROM VINYLATED INDENE AND POLYINDENE

\begin{tabular}{|c|c|c|c|c|c|c|c|}
\hline \multirow[b]{2}{*}{$\begin{array}{c}\text { Sample } \\
\text { Number }(1)\end{array}$} & \multirow{2}{*}{$\begin{array}{c}\text { Average } \\
\text { Molecular } \\
\text { Weight } \\
\text { of Indene } \\
\text { Starting } \\
\text { Material }\end{array}$} & \multirow{2}{*}{$\begin{array}{c}\text { Vinylation } \\
\text { Temperature } \\
\left({ }^{\circ} \mathrm{C}\right)\end{array}$} & \multirow{2}{*}{$\begin{array}{l}\text { Average } \\
\text { Molecular } \\
\text { Weight of } \\
\text { Vinylated. } \\
\text { Product }\end{array}$} & \multirow{2}{*}{$\begin{array}{c}\text { Coke Yield } \\
\text { After } \\
1,000^{\circ} \mathrm{C} \\
(\%)\end{array}$} & \multicolumn{3}{|c|}{ Properties After $2,800^{\circ} \mathrm{C}$} \\
\hline & & & & & $\begin{array}{l}\text { do0 } 4 \\
\text { (A) }\end{array}$ & $g$ factor & $\begin{array}{l}L_{c} \\
(A)\end{array}$ \\
\hline $10-17-68$ & Monomer & 220 & 338 & 27 & - & - & - \\
\hline $10-18-68$ & Monomer & 220 & 406 & 26 & - & - & - \\
\hline $11-10-69$ & $1,268(2)$ & 150 & 967 & 7 & 1.6836 & 0.858 & 185 \\
\hline $11-11-69$ & $1,268(2)$ & 200 & 786 & 43 & 1.6874 & 0.765 & 106 \\
\hline $11-12-69$ & $1,268(2)$ & 250 & 452 & 4 & 1.6820 & 0.894 & 253 \\
\hline $10-22-68$ & $1,838(3)$ & 220 & 954 & 45 & - & - & - \\
\hline
\end{tabular}

(1) Vinylation reaction consisted of heating indene or polyindene under an initial acetylene pressure of $\sim 200$ psi.

(2) Indene was polymerized by adding indene dropwise to a solution of boron trifluoride in benzene.

(3) Indene was polymerized by adding indene dropwise to a solution of tin chlur ide in benzene. 
of the polyindene samples at $200-220^{\circ} \mathrm{C}$ resulted in still higher coke yields $(40-45 \%)$, while reactions carried out at 150 and $250^{\circ} \mathrm{C}$ resulted in quite low coke yields (< 10\%). Apparently, little vinylation occurs at $150^{\circ} \mathrm{C}$ while, at $250^{\circ} \mathrm{C}$, severe degradation of the initial polymer occurs. Thus, the molecular species in this degraded polymer must be significantly different (though of similar molecular weight) from those formed by vinylation of the monomer.

Table 4 also includes data on the properties of carbons derived from vinylated polyindene samples. Examination of the microstructures of these carbon samples, as seen in Figure 9, suggests no correlations between the microstructural differences and the vinylation conditions or final polymer molecular weight. However, observed differences do reflect the different modes of polymerization employed to prepare the polyindene used as a starting material. Of the samples shown in Figure 9, three $(a, b, c)$ were derived from the same polyindene starting material (polymerized with $\mathrm{BF}_{3}$ catalyst; average molecular weight, 1,268), and showed similar microstructures (relatively finegrain mosaic texture). The fourth sample (d) was derived from a different polyindene sample (polymerized with $\mathrm{SnCl}_{4}$ catalyst; average molecular weight, 1,838 ) and exhibited a much finer grain texture.

\section{Miscellaneous Compounds Derived from Indene and Organic Halides}

Various compounds were prepared by reacting indene with organic halides. (8) Structures of these compounds are as follows:
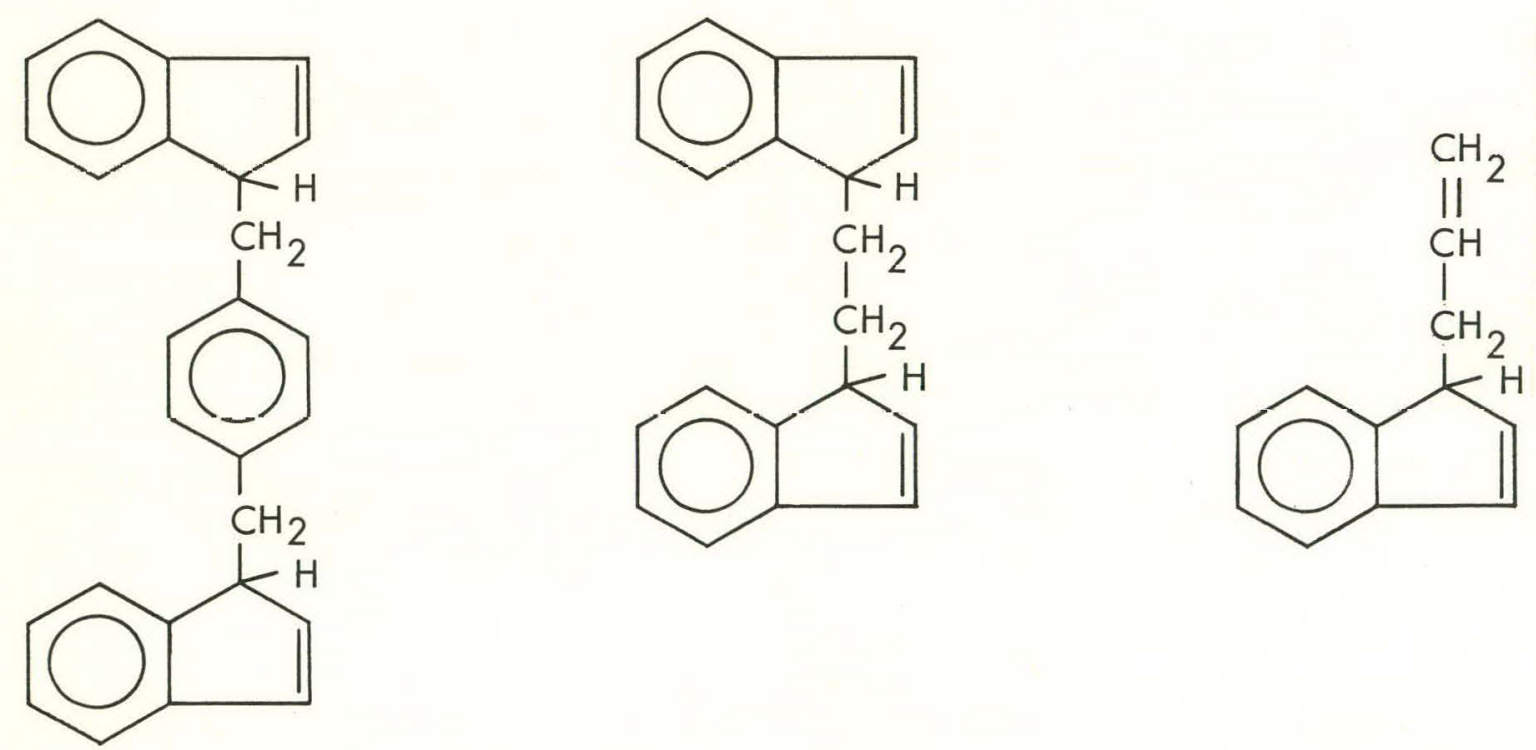

p-xylyleneindene

1, 2-diindenylethane

allylindene 


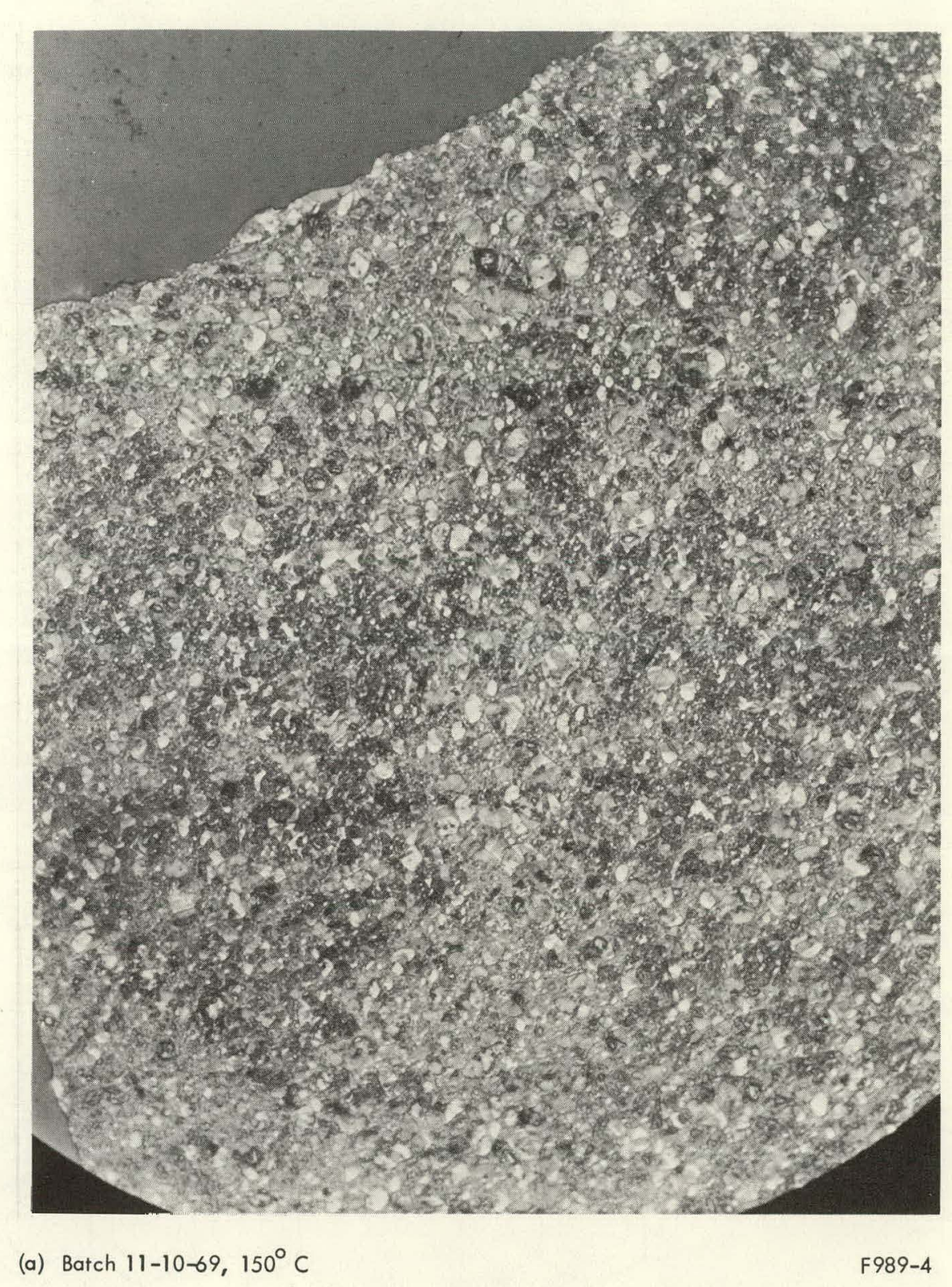

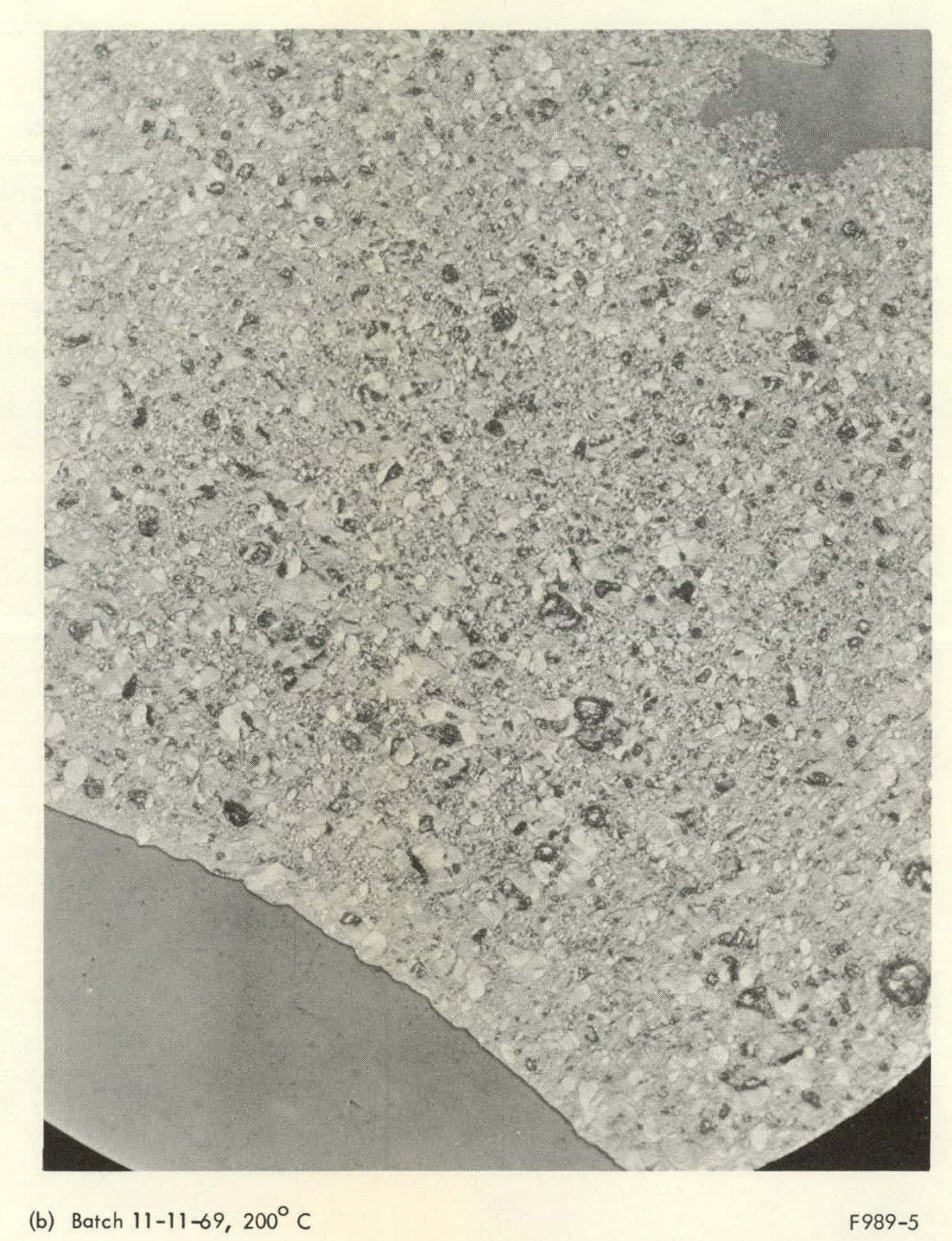

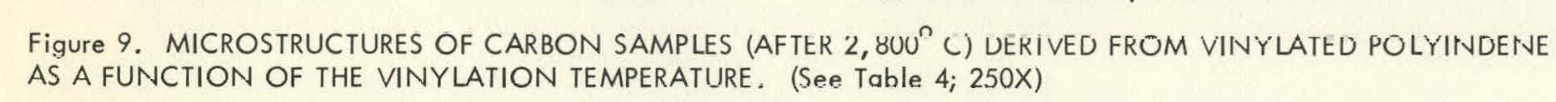

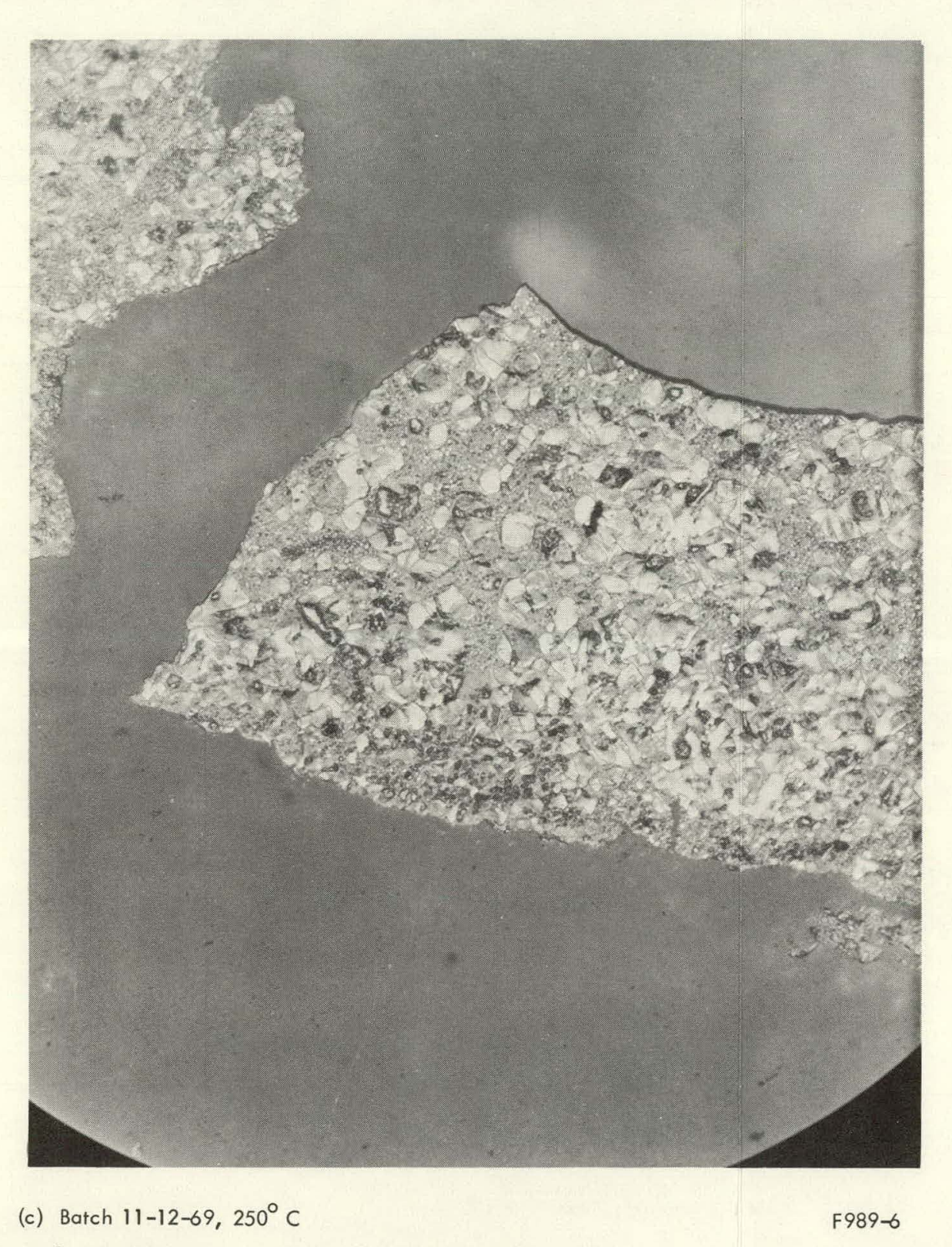

F989-6

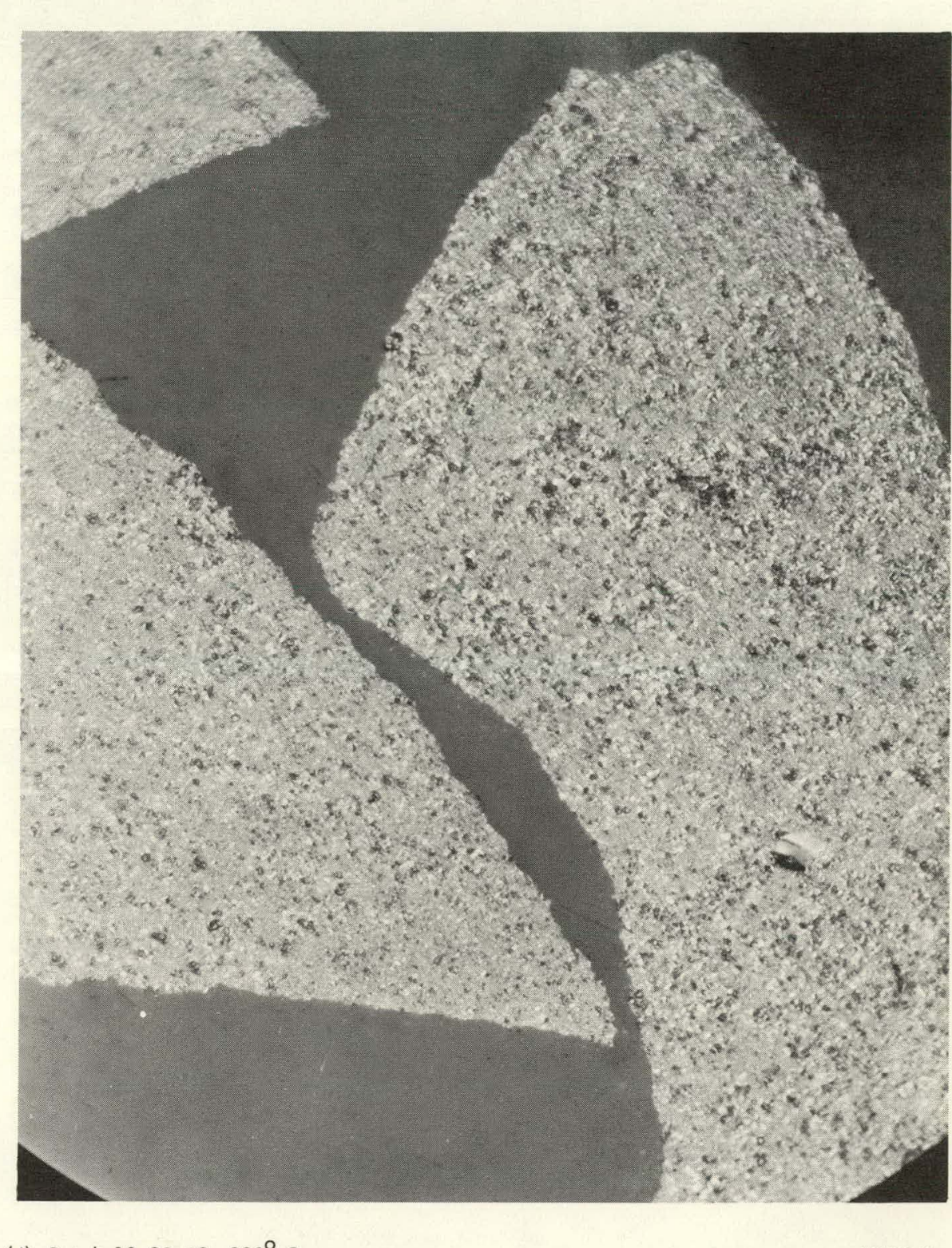

(d) Batch 10-22-68, $220^{\circ} \mathrm{C}$ 
These materials did not receive an extensive evaluation with respect to polymerization or carbonization procedures. All of the structures should function as crosslinking agents, but were not evaluated in this capacity. Preliminary coke-yield data were obtained and are included in Table 5. Coke yields of $30-35$ percent were obtained for p-xylyleneindene and 1,2-diindenylethane under the coking conditions described in Table 5 (air cure to $250^{\circ} \mathrm{C}$ in the presence of a polymerization catalyst). Thus, these two materials merit additional evaluation.

\section{Miscellaneous Benzofulvene Compounds}

Various benzofulvene compounds were synthesized by reacting indene with aldehyde or ketone compounds.(8) The parent compound (benzofulvene) and the various derivatives are depicted by the following structures:<smiles>C=C1C=Cc2ccccc21</smiles>

benzofulvene<smiles>C1=Cc2ccccc2C1=C(c1ccccc1)c1ccccc1</smiles>

diphenylbenzofulvene<smiles>CC(C)=C1C=Cc2ccccc21</smiles>

dimethyl benzofulvene<smiles>C1=Cc2ccccc2/C1=C/c1ccc(/C=C2\C=Cc3ccccc32)cc1</smiles>

p-xylylideneindene<smiles>C1=Cc2ccccc2C1=Cc1ccccc1</smiles>

phenylbenzofulverie<smiles>C1=Cc2ccccc2/C1=C/c1c2ccccc2cc2ccccc12</smiles>

9-anthrylideneindene 
Table 5

CARBONIZATION OF MISCELLANEOUS COMPOUNDS INCORPORATING INDENE

\begin{tabular}{|c|c|c|c|c|}
\hline $\begin{array}{c}\text { Sample } \\
\text { Number(1) }\end{array}$ & Compound & $\begin{array}{c}\text { Polymerization } \\
\text { Catalyst }\end{array}$ & $\begin{array}{c}\text { Weight Yield } \\
\text { After } 250^{\circ} \mathrm{C} \\
\text { Air Cure } \\
(\%)\end{array}$ & $\begin{array}{c}\text { Coke Yield } \\
\text { After } \\
1,000^{\circ} \mathrm{C} \\
(\%)\end{array}$ \\
\hline$E-29-2$ & $\underline{p}-x y l y l e n e i n d e n e$ & $\mathrm{BF}_{3} \cdot\left(\mathrm{C}_{2} \mathrm{H}_{5}\right)_{2} \mathrm{O}$ & 96 & 34 \\
\hline$E-29-4$ & 1,2-diindenylethane & $\mathrm{BF}_{3} \cdot\left(\mathrm{C}_{2} \mathrm{H}_{5}\right)_{2} \mathrm{O}$ & 97 & 29 \\
\hline$E-29-7$ & 1-allylindene & $\left(\mathrm{C}_{6} \mathrm{H}_{5} \mathrm{CO}\right)_{2} \mathrm{O}_{2}$ & 63 & 11 \\
\hline
\end{tabular}

(1) Compounds were synthesized by reacting indene with organic halides.

An additional compound, cinnamylideneindene, was omitted from this list and will be discussed in detail under a separate heading. Included in the present discussion will be cinnamylidenefluorene, a product formed by the reaction of cinnamaldehyde with fluorene, an indene analog:

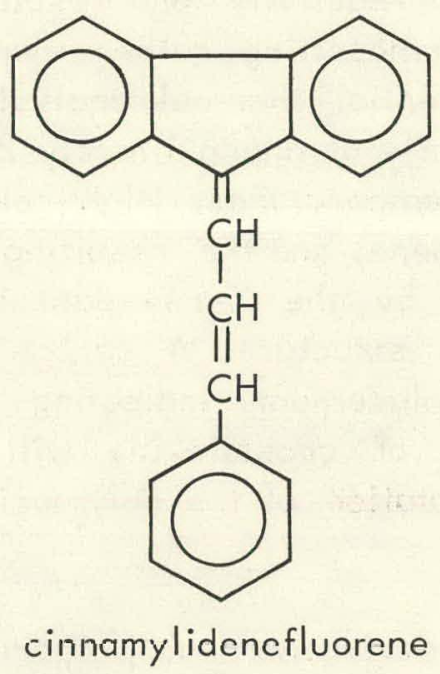

Coke yields obtained for the various benzofulvene derivatives are listed in Table 6 . With the exception of p-xylylideneindene and 9-anthrylideneindene, carbon derived from these materials received no additional evaluation. Coke yields of dimethylbenzofulvene $(20 \%)$ are significantly greater than that of indene $(<5 \%)$ due to the increased reactivity introduced by the isopropylidene adduct. Likewise, the presence of extensive conjugated bonding in phenylbenzofulvene and diphenylbenzofulvene results in greater reactivity than indene and, thus, greater coke yields $(\sim 40 \%)$.

The reactivity of $p$-xylylideneindene is such that polymerization occurs on fusion $\left(r 240^{\circ} \mathrm{C}\right)$. A gain, the high degree of conjugation in the structure gives 
Table 6

CARBONIZATION OF MISCELLANEOUS BENZOFULVENE DERIVATIVES

\begin{tabular}{|c|c|c|c|c|c|}
\hline \multirow[b]{2}{*}{$\begin{array}{l}\text { Sample } \\
\text { Number }\end{array}$} & \multirow[b]{2}{*}{ Compound } & \multirow[b]{2}{*}{ Air Cure (1) } & \multirow{2}{*}{$\begin{array}{c}\text { Coke Yield } \\
\text { After } \\
1,000^{\circ} \mathrm{C}\end{array}$} & \multicolumn{2}{|c|}{$\begin{array}{c}\text { Properties After } \\
2,800^{\circ} \mathrm{C}\end{array}$} \\
\hline & & & & $\begin{array}{l}\text { do04 } \\
\text { (A) }\end{array}$ & $\mathrm{g}$ factor \\
\hline$E-29-9(2)$ & Dimethylbenzofulvene $\left(\mathrm{C}_{12} \mathrm{H}_{12}\right)$ & Yes & 20 & - & - \\
\hline $3-G-2$ & Phenylbenzofulvene $\left(\mathrm{C}_{16} \mathrm{H}_{12}\right)$ & Yes & 42 & - & - \\
\hline$E-29-8(2)$ & Diphenylbenzofulvene $\left(\mathrm{C}_{22} \mathrm{H}_{16}\right)$ & Yes & 39 & - & - \\
\hline LDS-1-G-1 & Diphenylbenzofulvene $\left(\mathrm{C}_{22} \mathrm{H}_{16}\right)$ & Yes & 34 & - & - \\
\hline $7-1-67 A$ & $\underline{\mathrm{p}}-x y$ lylideneindene $\left(\mathrm{C}_{26} \mathrm{H}_{18}\right)$ & Yes & 75 & 1.7104 & 0.224 \\
\hline $7-1-67 A$ & $\underline{\mathrm{p}}-\mathrm{xy}$ lylideneindene $\left(\mathrm{C}_{26} \mathrm{H}_{18}\right)$ & No & 61 & 1.6986 & 0.506 \\
\hline $2-37-70 C_{1}$ & Anthrylideneindene $\left(\mathrm{C}_{24} \mathrm{H}_{16}\right)$ & Yes & 36 & 1.6831 & 0.871 \\
\hline $2-37-70 C 2$ & Anthrylideneindene $\left(\mathrm{C}_{24} \mathrm{H}_{16}\right)$ & No & 29 & 1.6805 & 0.930 \\
\hline
\end{tabular}

(1) Air cure consisted of heating in a programmed cycle to $250^{\circ} \mathrm{C}$.

(2) Benzoyl peroxide was included as a catalyst.

rise to this high order of reactivity, and results in crosslinking characteristics that produce a thermosetting rather than a thermoplastic material. As indicated by the differential thermal analysis (DTA) scan in Figure 10, polymerization occurs initially at approximately $240^{\circ} \mathrm{C}$, followed by additional polymerization at higher temperatures. High coke yields $(>60 \%)$ are characteristic of $\mathrm{p}$-xylylideneindene, and the resulting carbon has a low order of eryslallinily, us indicated by the X-ray data in Table 6. Metallographs of this carbon show no grain structure. A carbon density of $1.44 \mathrm{gms} / \mathrm{ml}$ was determined by helium displacement, indicating some closed porosity. Apparently, the high degree of crosslinking will not allow a fluid or plastic state appropriate for orientation of the polymeric liquid crystal phase prior to pyrolysis.

An additional benzofulvene derivative was prepared by condensing 9-anthraldehyde with indene. This compound (9-anthrylideneindene) is highly aromatic

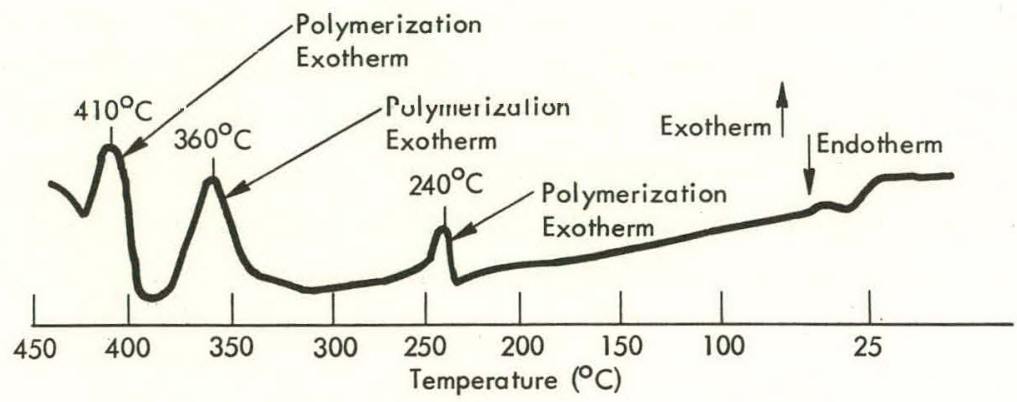

Figure 10. DIFFERENTIAL THERMAL ANALYSIS SCAN OF p-XYLYLIDENEINDENE. 
and had coke yields similar to phenyl and diphenylbenzofulvene. Some slight increase in coke yield resulted for samples that were air cured prior to carbonization. As reported in Table 6, carbon from 9-anthrylideneindene is quite graphitic, with the air-cured sample having a slightly lower order of graphiticity than the uncured sample. Figure 11 shows that the microstructures of these carbons are highly anisotropic and quite similar to carbon derived from acenaphthalene.

An evaluation of cinnamylidenefluorene (molecular weight 278) consisted of polymerization and carbonization studies. Samples were heated for various times at 200 and $300^{\circ} \mathrm{C}$, both in air and inert atmospheres. As indicated in Table 7, heating at $200^{\circ} \mathrm{C}$ in either air or inert atmosphere did not cause polymerization of cinnamylidenefluorene. However, heating at $300^{\circ} \mathrm{C}$ did result in significant polymerization, as the data in Table 7 and the GPC scans in Figure 12 point out. On the basis of the polymerization characteristics and coke-yield data, cinnamylidenefluorene appeared to lack the reactivity of benzofulvene compounds which have reactive unsaturated bonding in the five-member ring of the indene moiety. Though cinnamylidenefluorene is highly conjugated, the nonaromatic conjugated sites at which the reaction would be initiated are somewhat shielded by the fluorene adduct. These factors probably explain the lack of reactivity at $200^{\circ} \mathrm{C}$. Coke-yield values ranged from 15 to 30 percent.

Table 7

POLYMERIZATION AND CARBONIZATION OF CINNAMYLIDENEFLUORENE

\begin{tabular}{|c|c|c|c|c|c|c|c|c|}
\hline \multirow[b]{2}{*}{$\begin{array}{l}\text { Sample } \\
\text { Number }\end{array}$} & \multicolumn{6}{|c|}{ Polymerization } & Polymer & $\begin{array}{c}\text { nization } \\
\text { Coke Yield } \\
\text { After } \\
1,000^{\circ} \mathrm{C}\end{array}$ \\
\hline & $\begin{array}{c}\text { Temperature } \\
\left({ }^{\circ} \mathrm{C}\right)\end{array}$ & $\begin{array}{l}\text { Time } \\
\text { (hrs) }\end{array}$ & Atmosphere & $\begin{array}{l}\text { Polymer } \\
\text { Melting } \\
\text { Range } \\
\left({ }^{\circ} \mathrm{C}\right)\end{array}$ & $\begin{array}{c}\text { Average } \\
\text { Molecular } \\
\text { Weight }\end{array}$ & $\begin{array}{l}\text { Weight Loss on } \\
\text { Polymerization } \\
\text { (\%) }\end{array}$ & $\begin{array}{c}\text { Coke Yield } \\
\text { After } \\
1,000^{\circ} \mathrm{C} \\
(\%)\end{array}$ & $\begin{array}{c}\text { Including } \\
\text { Weight Loss on } \\
\text { Polymerization } \\
(\%)\end{array}$ \\
\hline$G-2$ & 200 & 4.5 & Inert & $150-155$ & 299 & 10 & 17 & 15 \\
\hline G-11 & 300 & 4.0 & Inert & $52-70$ & 493 & 22 & 30 & 23 \\
\hline$G-13$ & 300 & 6.5 & Inert & $100-125$ & 489 & 45 & 35 & 19 \\
\hline$G-7$ & 200 & 24 & Air & $125-155$ & 298 & Negligible & 17 & 17 \\
\hline G-12 & 300 & 8 & Air & $\sim 50$ & 333 & 10 & 27 & 24 \\
\hline G-14 & 300 & 72 & Air & $165-180$ & 676 & 56 & 61 & 27 \\
\hline L-1-99-9 & 250 & $50(1)$ & Air & - & - & - & - & 30 \\
\hline
\end{tabular}

(1) Sample was heated in a programmed cycle which attained a maximum of $250^{\circ} \mathrm{C}$ in $\sim 50$ hours.

Carbon derived from cinnamylidenefluorene is quite graphitic, as indicated in Figure 13. The d004, $g$ factor, and $L_{c}$ for the sample shown were $1.6828 \mathrm{~A}$, 0.87 , and $240 \mathrm{~A}$, respectively. 


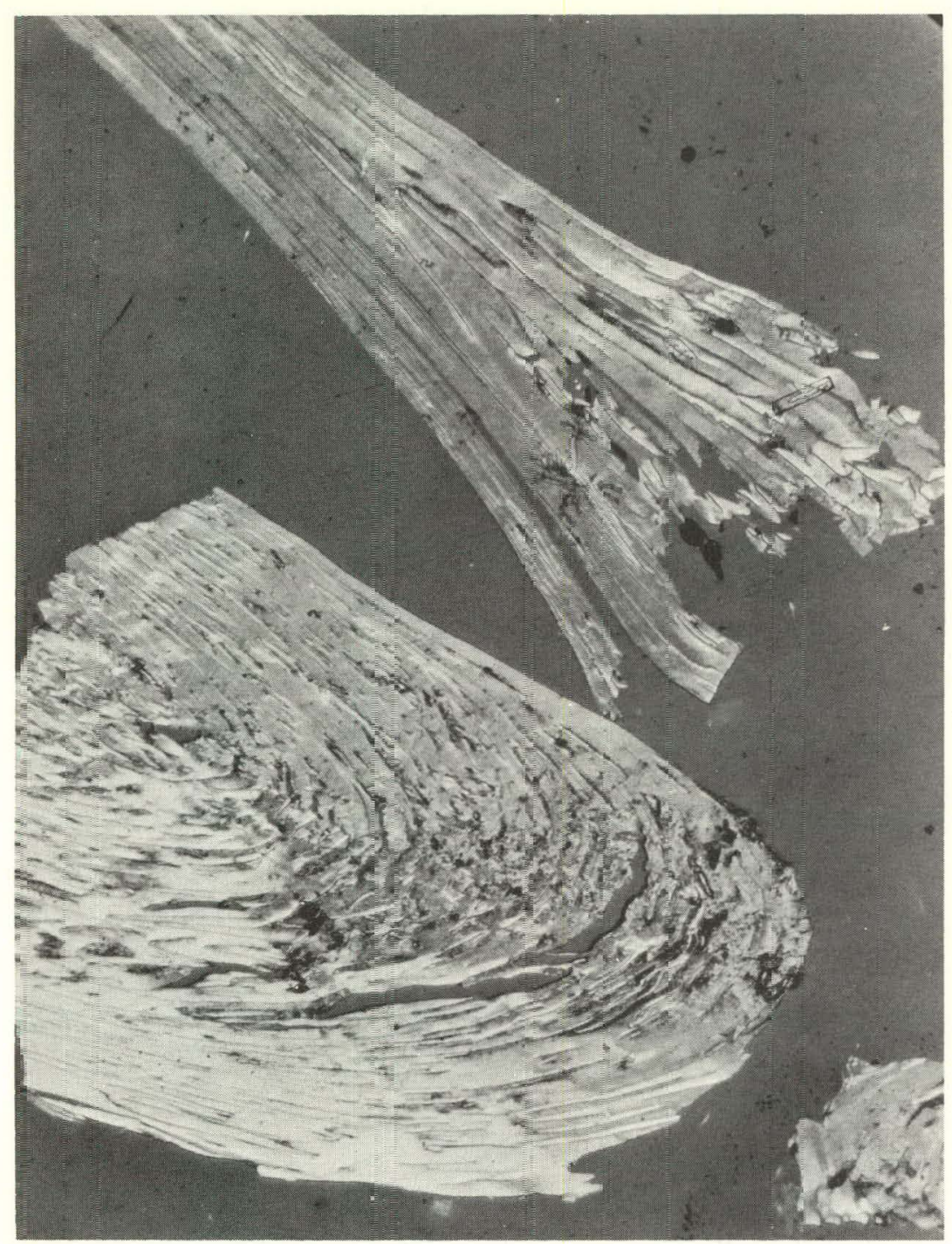

(a) Received an Air Cure Prior to Earbonization

Gó20-5

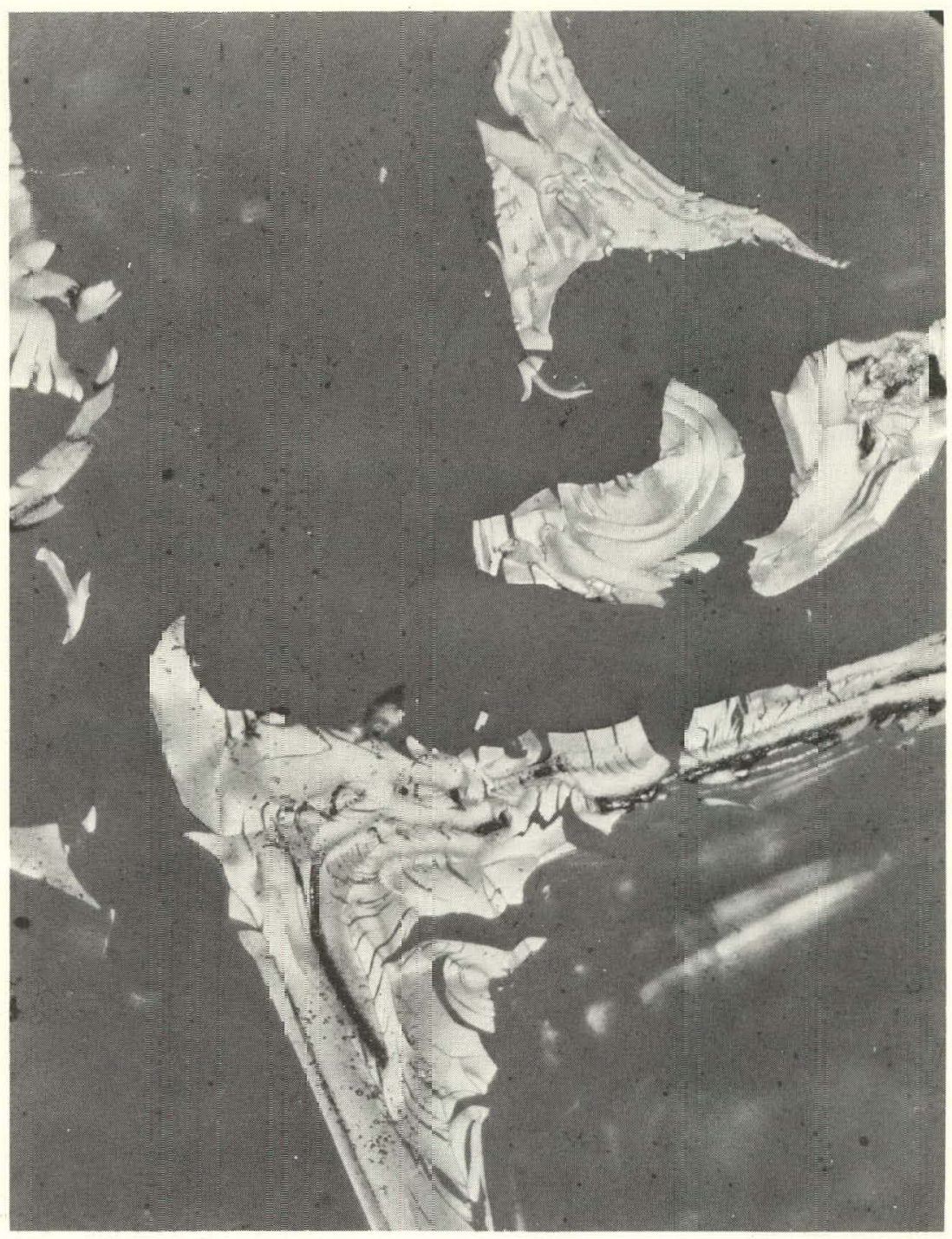

(b) Was Not Air Eured Jicr to Carbenization

G620-5

Figure 11. MICROSTRUCTURES OF CARBON (AFTER $2,800^{\circ} \mathrm{C}$ ) DERIVE 2 FROM A VTHRYLIDEN NDENE. (250X) 


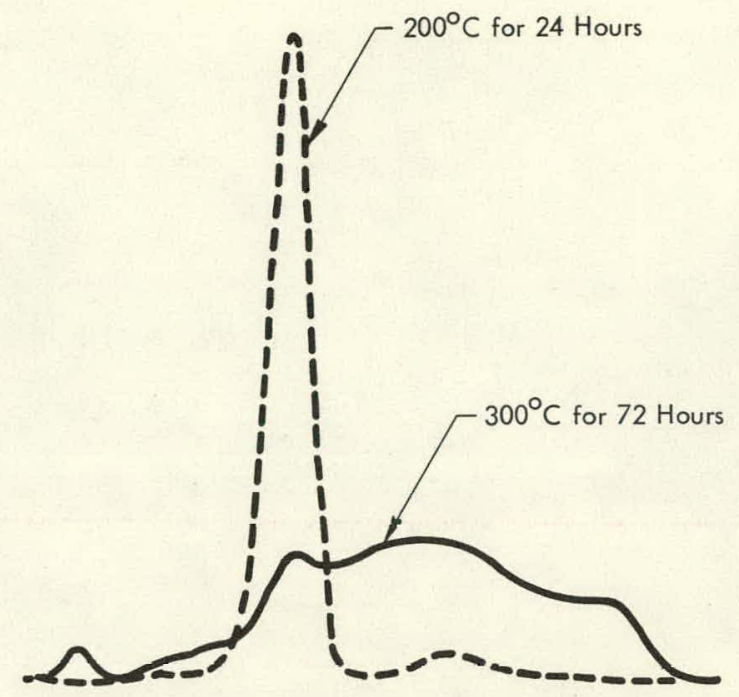

Figure 12. GEL PERMEATION CHROMATOGRAPHY SCANS SHOWING THE MOLECULAR DISTRIBUTION OF CINNAMYLIDENEFLUORENE ON HEAT TREATMENT IN AIR.

\section{Cinnamylideneindene (CAl)}

Properties of carbon derived from CAI $\left(\mathrm{C}_{18} \mathrm{H}_{14}\right)$ were examined in greater detail than those of other benzofulvene derivatives. CAI is prepared by the room-temperature reaction of indene with cinnamaldehyde in the presence of methanol-potassium hydroxide solutions. (8) GPC scans showing the molecular distribution of typical CAl products are included in Figure 14. The structure of CAI is:

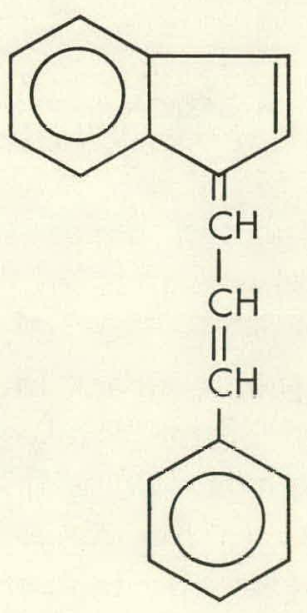

cinnamylideneindene (CAI) 


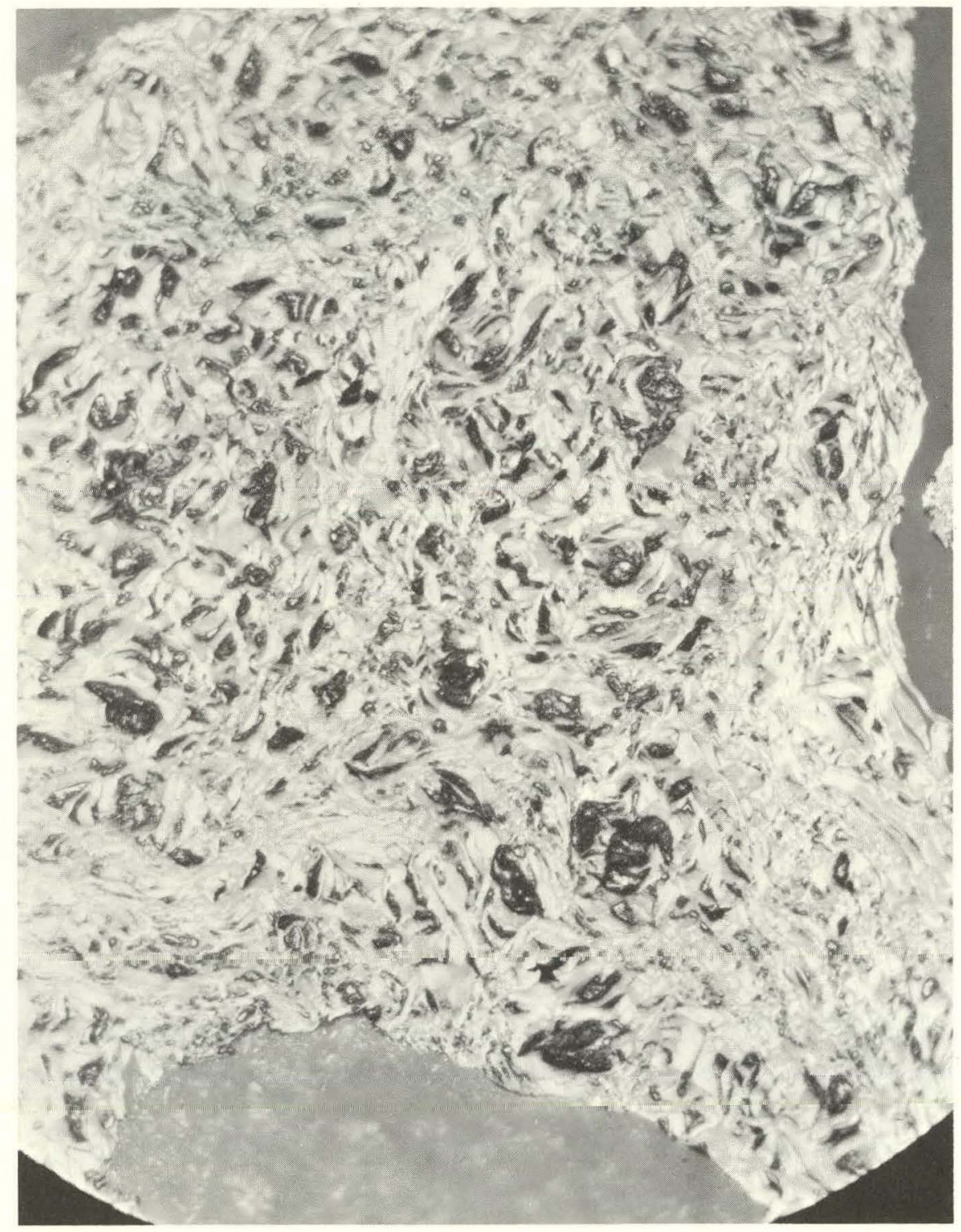

F388-7

Figure 13. MICROSTRUCTURE OF A CARBON SAMPLE (AFTER $2,800^{\circ} \mathrm{C}$ ) DERIVED FROM AN AIR-CURED SAMPLE OF CINNAMYLIDENEFLUORENE. (250X)

Due to the presence of unsaturated bonds that are highly conjugated, this structure is quite reactive and results in the polymerization of CAl when heated to the melting temperature $\left(\sim 190^{\circ} \mathrm{C}\right)$. This tendency toward polymerization is apparent from the thermogram in Figure 15, which shows a significant polymerization exotherm immediately succeeding the endotherm associated with fusion. As subsequent data will indicate, this initial polymeric product degrades at temperatures in the range from 250 to $300^{\circ} \mathrm{C}$, but begins to increase in molecular weight as the temperature approaches $350^{\circ} \mathrm{C}$. This secondary polymerization is also apparent in Figure 15. The weight loss 


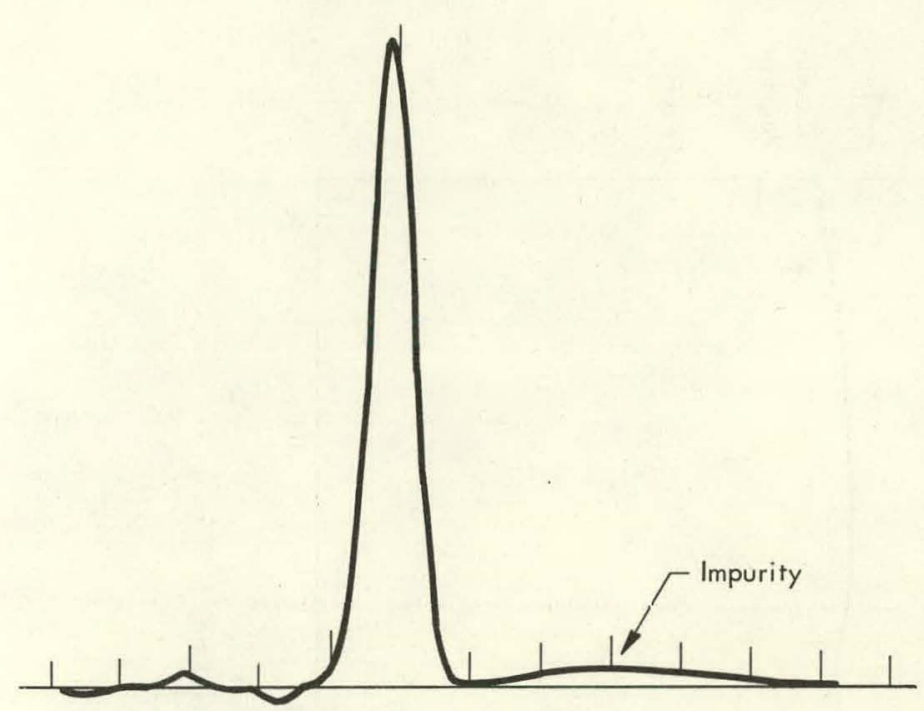

(a) As-produced Sample

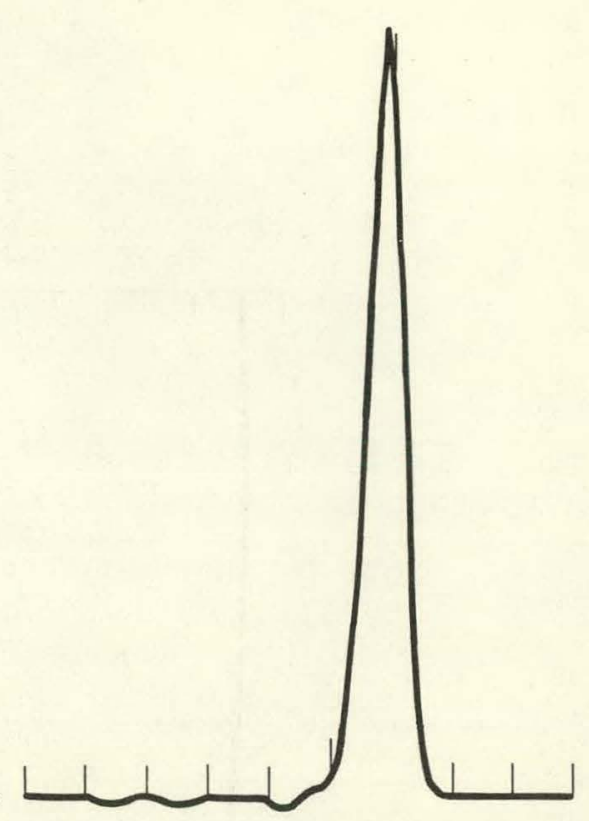

(b) After Recrystallization from Hot Benzene

Figure 14. GEL PERMEATION CHROMATOGRAPHY SCANS SHOWING THE MOLECULAR DISTRIBUTION OF LABORATORY-PRODUCED CINNAMYLIDENEINDENE.

associated with pyrolytic decomposition becomes significant at approximately $350^{\circ} \mathrm{C}$ and continues at a relatively constant rate to approximately $550^{\circ} \mathrm{C}$. Though susceptible to polymerization at a temperature of $200^{\circ} \mathrm{C}, \mathrm{CAl}$ produces a thermoplastic rather than a thermosetting polymer.

Coke yields of CAI and CAI polymers were, in general, approximately 40 percent. Certain polymerization procedures, as will be discussed, result in coke yields of $55-60$ percent. The volume yields (after 1,000 $\mathrm{C}$ ) of CAI materials corresponding to coke yields of 40 percent were approximately 30 percent. These values were calculated using coke-yield data and massdensity-volume relationships as discussed previously (Page ). The density of CAI powder is approximately $1.2 \mathrm{gms} / \mathrm{ml}$ while that of the derived carbon (after $1,000^{\circ} \mathrm{C}$ ) is approximately $1.6 \mathrm{gms} / \mathrm{ml}$.

Properties of carbons from CAI were determined for a variety of samples and were found to be influenced significantly by certain inorganic contaminants and to a lesser degree by polymerization conditions. These effects are discussed in the lupics that follow.

Effect of Inorganic Constituents on the Properties of CAI-Derived Carbon - One synthetic procedure used to prepare CAl involves the use of methanol-potassium hydroxide solutions, and CAI products are thus contaminated with residual potassium hydroxide and/or other potassium compounds. The degree to which 


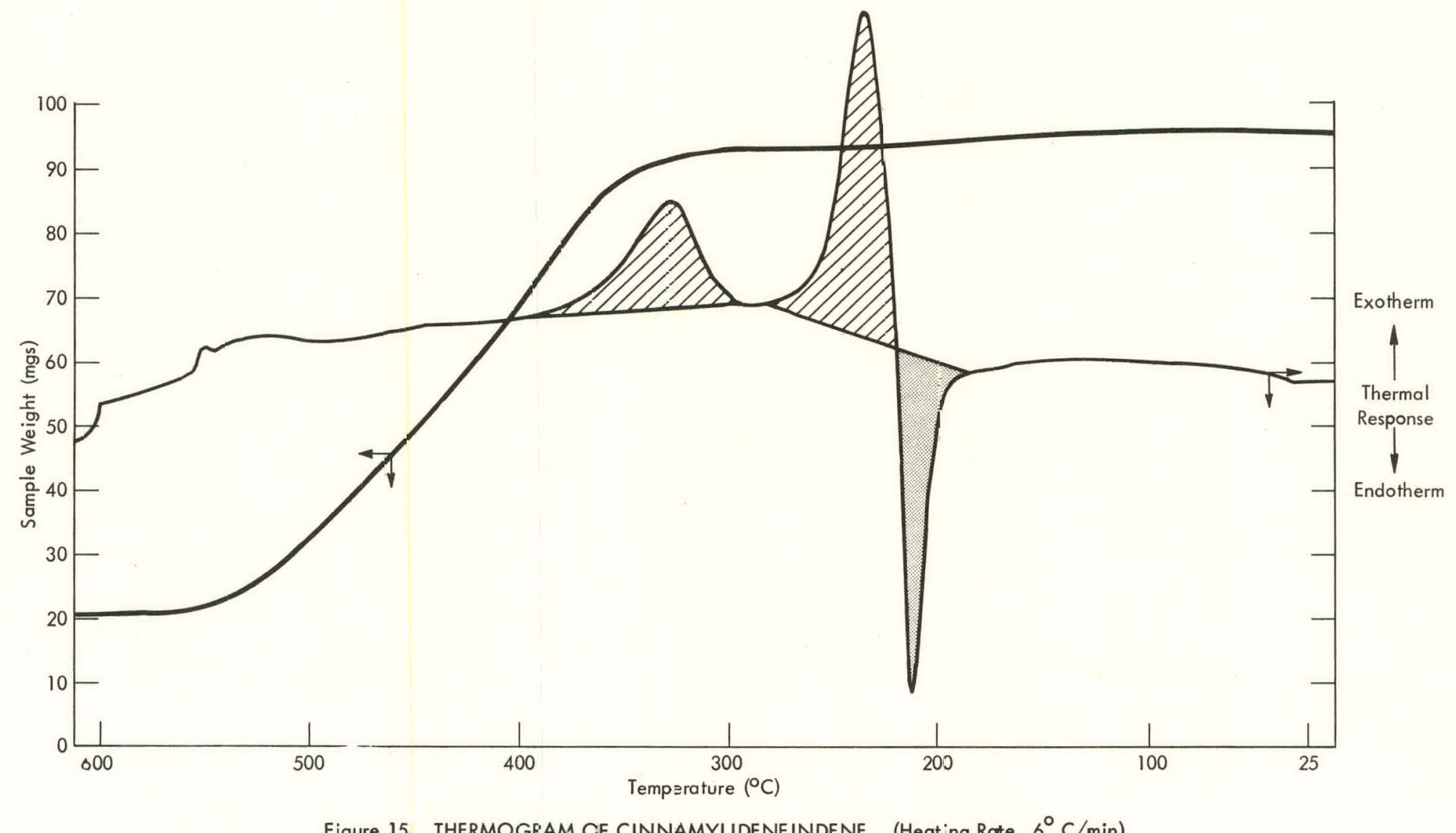

Figure 15. THERMOGRAM CF CINNAMYLIDENEINDENE. (Heat ing Rate, $6^{\circ} \mathrm{C} / \mathrm{min}$ ) 
these potassium compounds are removed by various purification procedures (including washing with methanol and/or methanol-acetic acid mixtures) influences significantly the properties of the derived carbon. The higher the potassium content (as measured by X-ray fluorescence), the less graphitic the carbon. Samples of CAI with various potassium contents were obtained by using various washing procedures, and the potassium contents were determined to be $8,370,4,320,3,920,3,590,1,660$, and 40 ppm. Properties of the derived carbons are listed in Table 8 and plotted in Figure 16. The microstructures can be seen in Figure 17.

Table 8

PROPERTIES OF CARBONS DERIVED FROM CINNAMYLIDENEINDENE SAMPLES WITH A VARIABLE POTASSIUM CONTENT

\begin{tabular}{|c|c|c|c|c|}
\hline \multirow[b]{2}{*}{$\begin{array}{c}\text { Sample } \\
\text { Number }\end{array}$} & \multirow{2}{*}{$\begin{array}{l}\text { Potassium } \\
\text { Content (1) } \\
(\mathrm{ppm})\end{array}$} & \multicolumn{3}{|c|}{ Properties After $2,800^{\circ} \mathrm{C}$} \\
\hline & & $\begin{array}{l}\text { do0 } \\
\text { (A) }\end{array}$ & $g$ factor & $\begin{array}{l}L_{c} \\
\text { (A) }\end{array}$ \\
\hline $\mathrm{H} 2-58 \mathrm{~A}$ & 8,370 & - & - & - \\
\hline $\mathrm{H} 2-58 \mathrm{~B}$ & 4,320 & 1.6931 & 0.635 & 97 \\
\hline $\mathrm{H} 2-58 \mathrm{C}$ & 3,920 & 1.6931 & 0.635 & 97 \\
\hline $\mathrm{H} 2-58 \mathrm{D}$ & 3,590 & 1.6917 & 0.671 & 105 \\
\hline $\mathrm{H} 2-58 \mathrm{E}$ & 1,660 & 1.6885 & 0.742 & 122 \\
\hline $\mathrm{H} 2-47 \mathrm{~B}$ & 690 & 1.6860 & 0.800 & 153 \\
\hline$H 2-56 \mathrm{D}$ & 40 & 1.6825 & 0.882 & 203 \\
\hline
\end{tabular}

(1) Measured by X-ray fluorescence.

Thus, CAI with a residual potassium concentration of approximately 8,000 $\mathrm{ppm}$ does not produce a graphitic carbon. Samples with potassium concentrations in the range from 3,000 to $5,000 \mathrm{ppm}$ produce graphitic carbons with uniform, fine-grain textures. The tendency toward crystalline, coarse-grain carbons is apparent for samples containing lower potassium concentrations.

Later experiments indicated that similar results were obtained when potassium acetate and potassium carbonate were incorporated into CAI samples. Elucidation of the mechanisms by which certain potassium compounds influence the carbon properties is incomplete. However, it is currently thought that the potassium compounds influence the polymerization reactions of CAl, thus modifying the polymeric form of the precursor. DTA scans, shown in Figure 18, indicated a lowering of the melting and polymerization temperatures with increasing potassium content (incorporated as $\mathrm{KOH}$ ).

Other less basic compounds (such as $\mathrm{K}_{2} \mathrm{SO}_{4}$ and $\mathrm{KCl}$ ) do not appear to influence the carbon properties. Thus, it is unlikely that the influence can be 
attributed to interstitial effects of potassium on crystal formation and growth. The use of potassium compounds in CAI represents a method of controlling the properties of those carbons designated for applications which can tolerate potassium contamination.

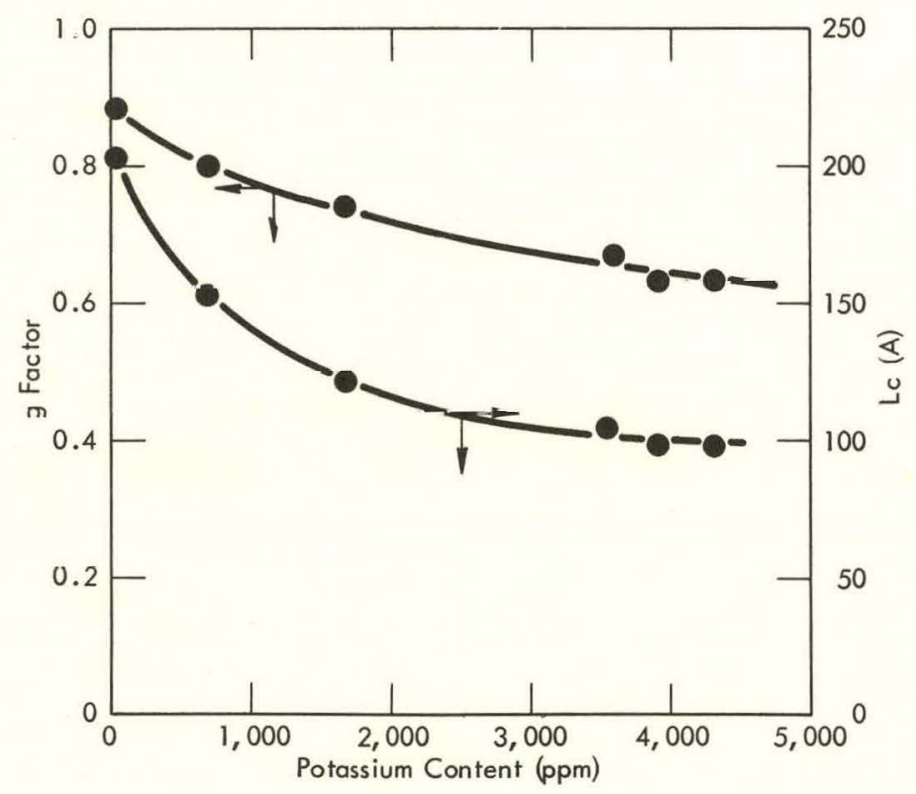

Figure 16. CRYSTALLITE SIZE (LC) AND g FACTOR OF CARBON SAMPLS (AFTER $2,800^{\circ}$ C) DERIVEU HRUM CINNAMYLIDENEINDENE SAMPLES WITH A VARIABLE POTASSIUM CONTENT.

Autoclave Polymerization - Samples of CAI were polymerized by autoclave treatment at various temperatures and for various times. The polymeric samples were subsequently carbonized both with and without an air cure. Autoclave temperatures of $200,250,300$, and $340^{\circ}$ C were empleyed; and, as can be scon in Table 9 , the polymer molecular weights decreased with an increasing polymerization temperature. Figure 19 shows the correlation between the average molecular weights and autoclave remperatures for samples that received two and six-hour heat treatments.

The temperature at which the two curves initially cross $\left(\sim 265^{\circ} \mathrm{C}\right)$ should be indicative of the temperature above which polymerization ceases to be the predominant reaction during prolonged heating, and where degradation reactions become the dominant process. Below $265^{\circ} \mathrm{C}$, longer heating periods resulted in higher molecular weights; above $265^{\circ} \mathrm{C}$, the reverse was noted. Likewise, above $340^{\circ} \mathrm{C}$, polymerization again becomes the dominant process on prolonged heating. The degree of degradation appeared to reach a maximum 


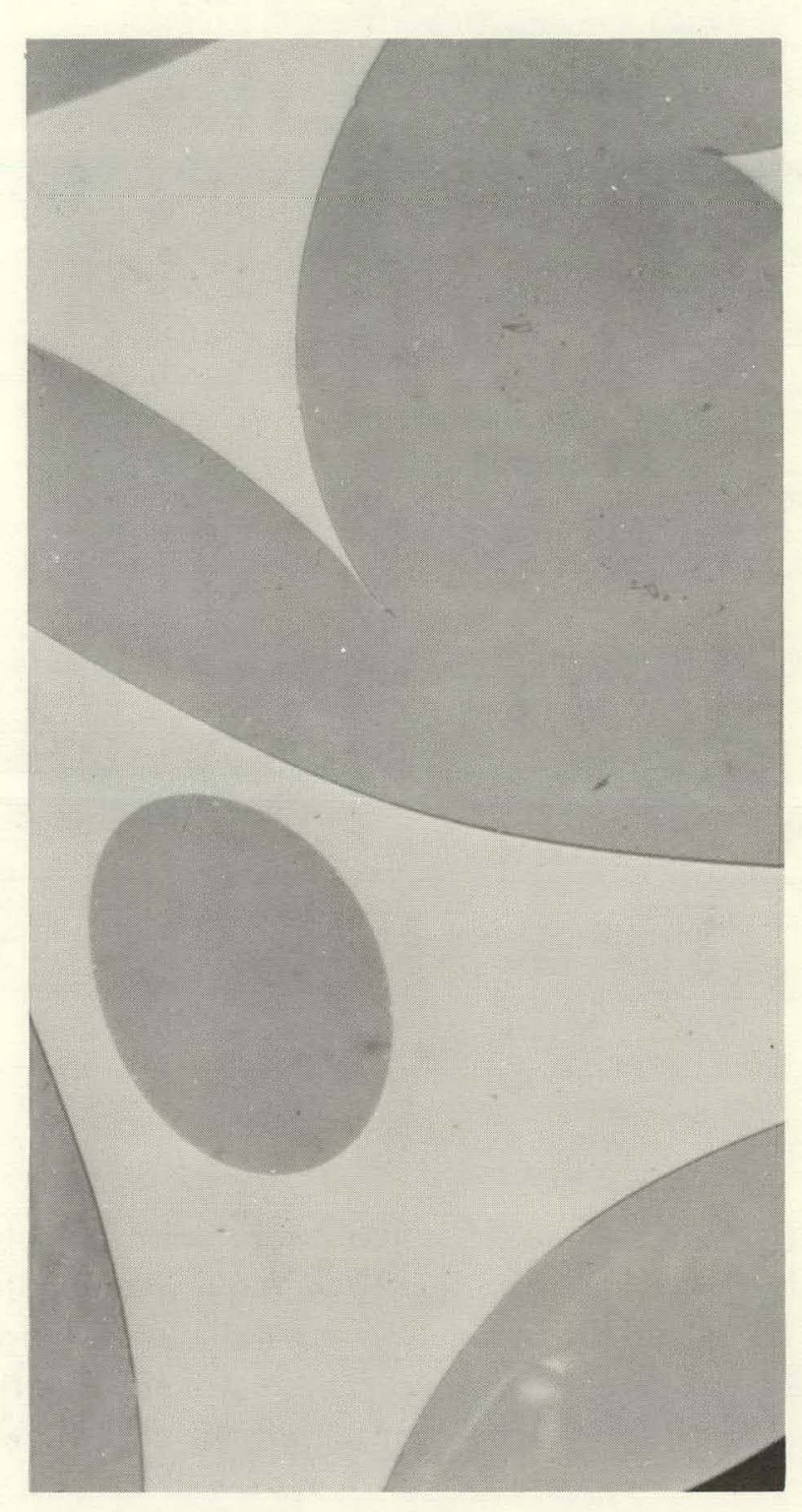

(a) With $8,370 \mathrm{ppm} \mathrm{K}$

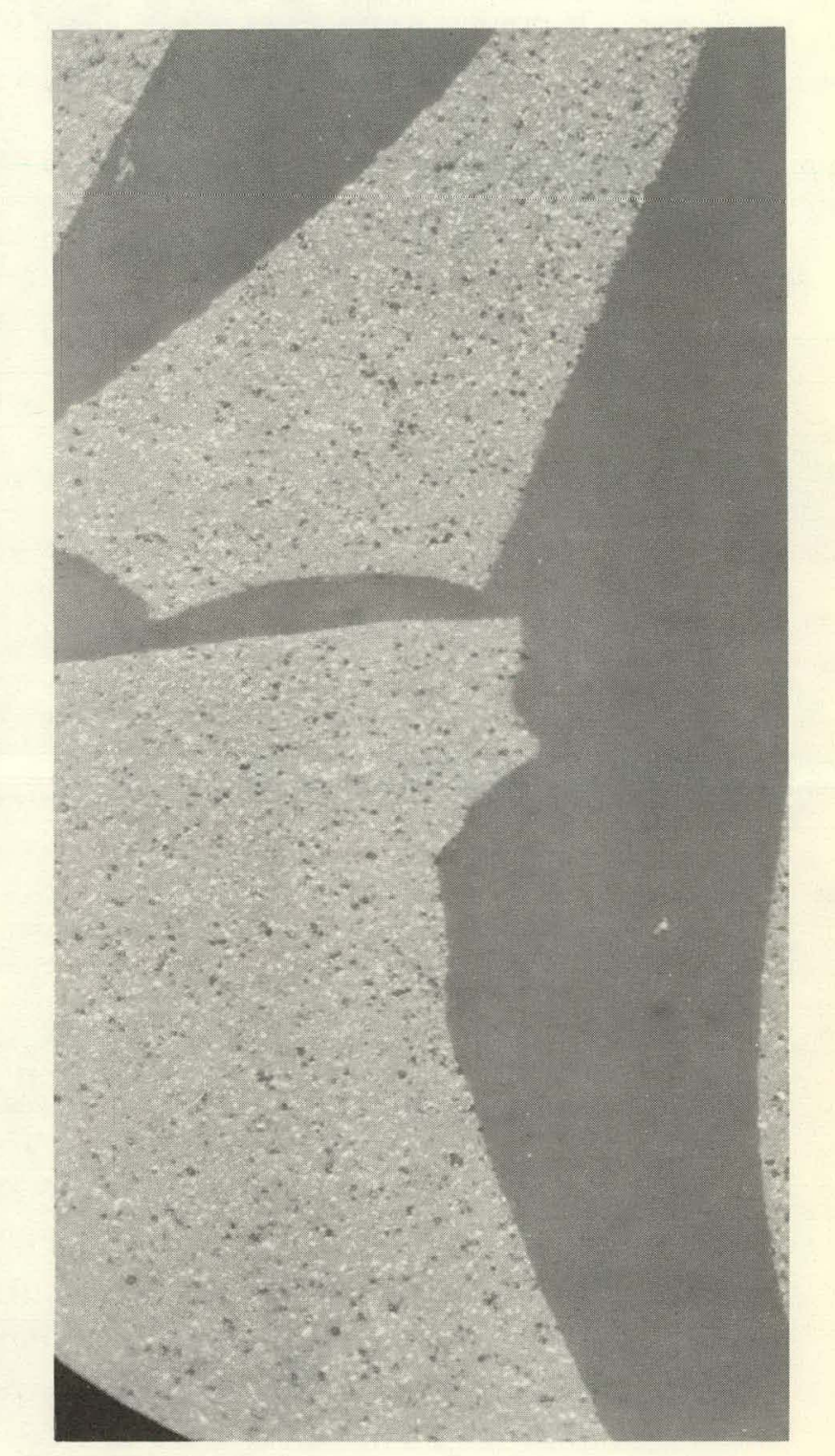

(b) With $4,320 \mathrm{ppm} \mathrm{K}$

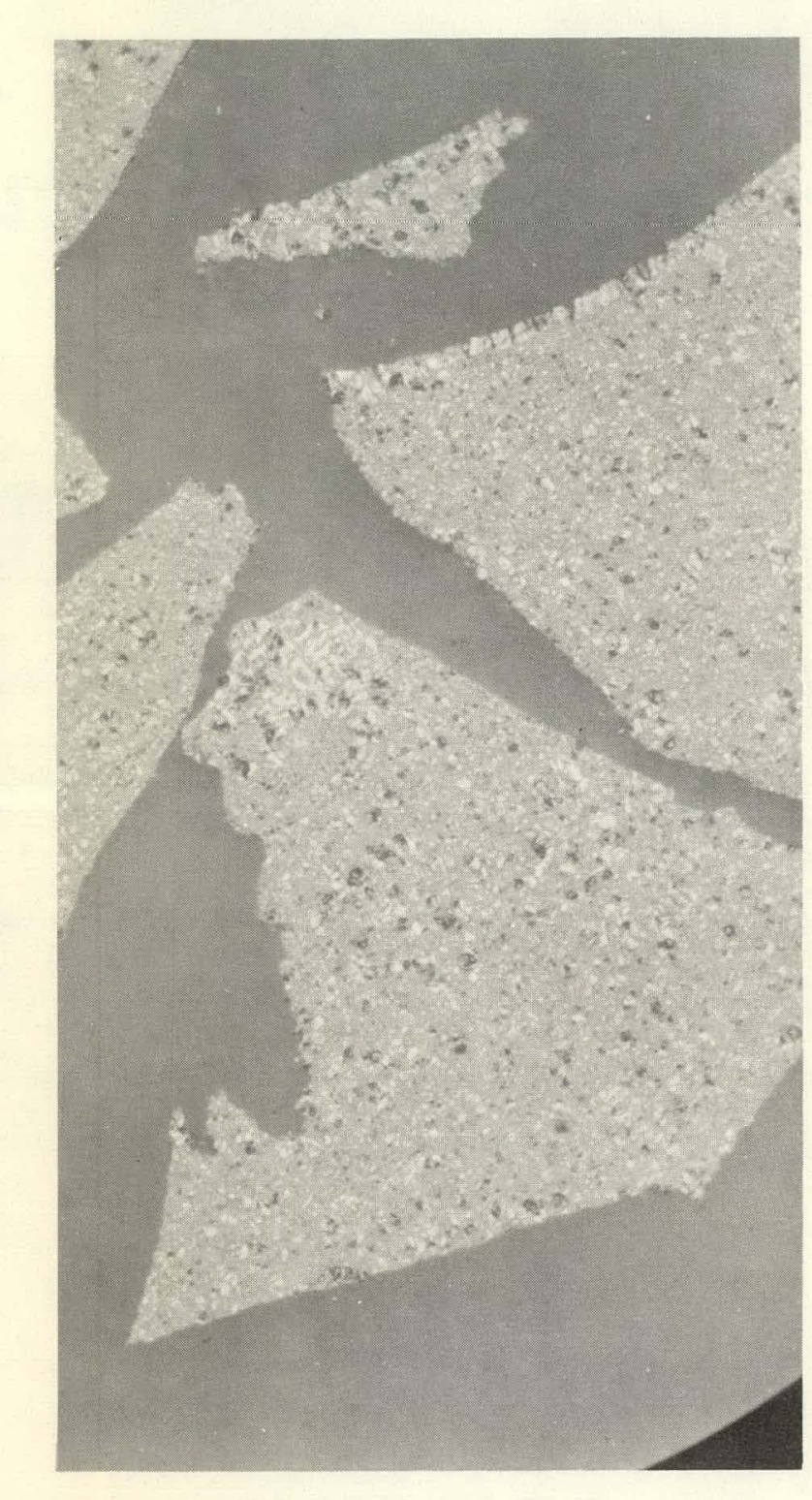

6747-3 (c) With 3,920 ppm K

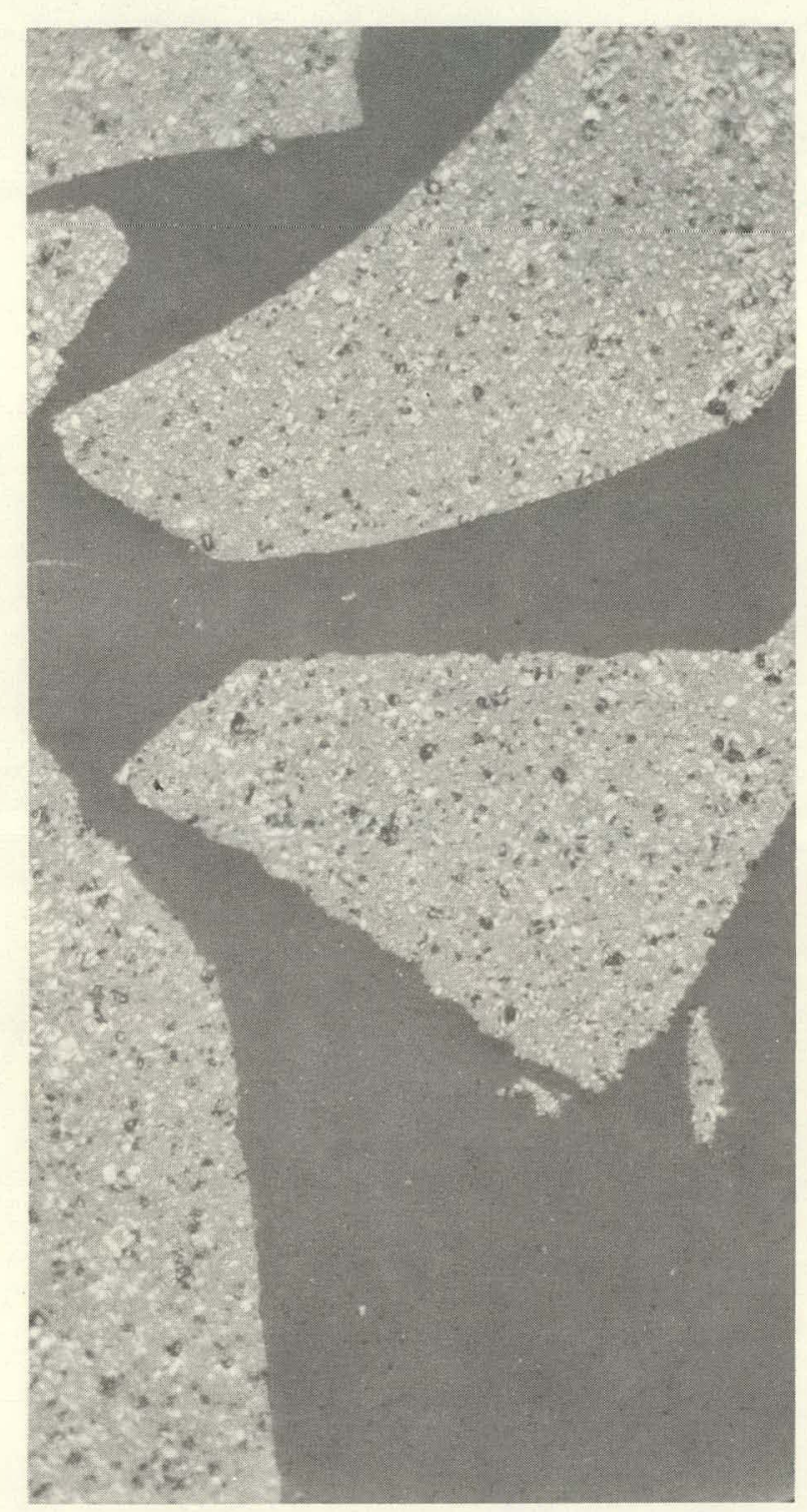

G747-4 (d) With 3,590 ppm K

6747-6

Figure 17 . MICROSTRUCTURES OF CARBON SAMPLES (AFTER 2,800
CONTAINING VARIOUS CONCENTRATIONS OF POTASSIUM. (250)

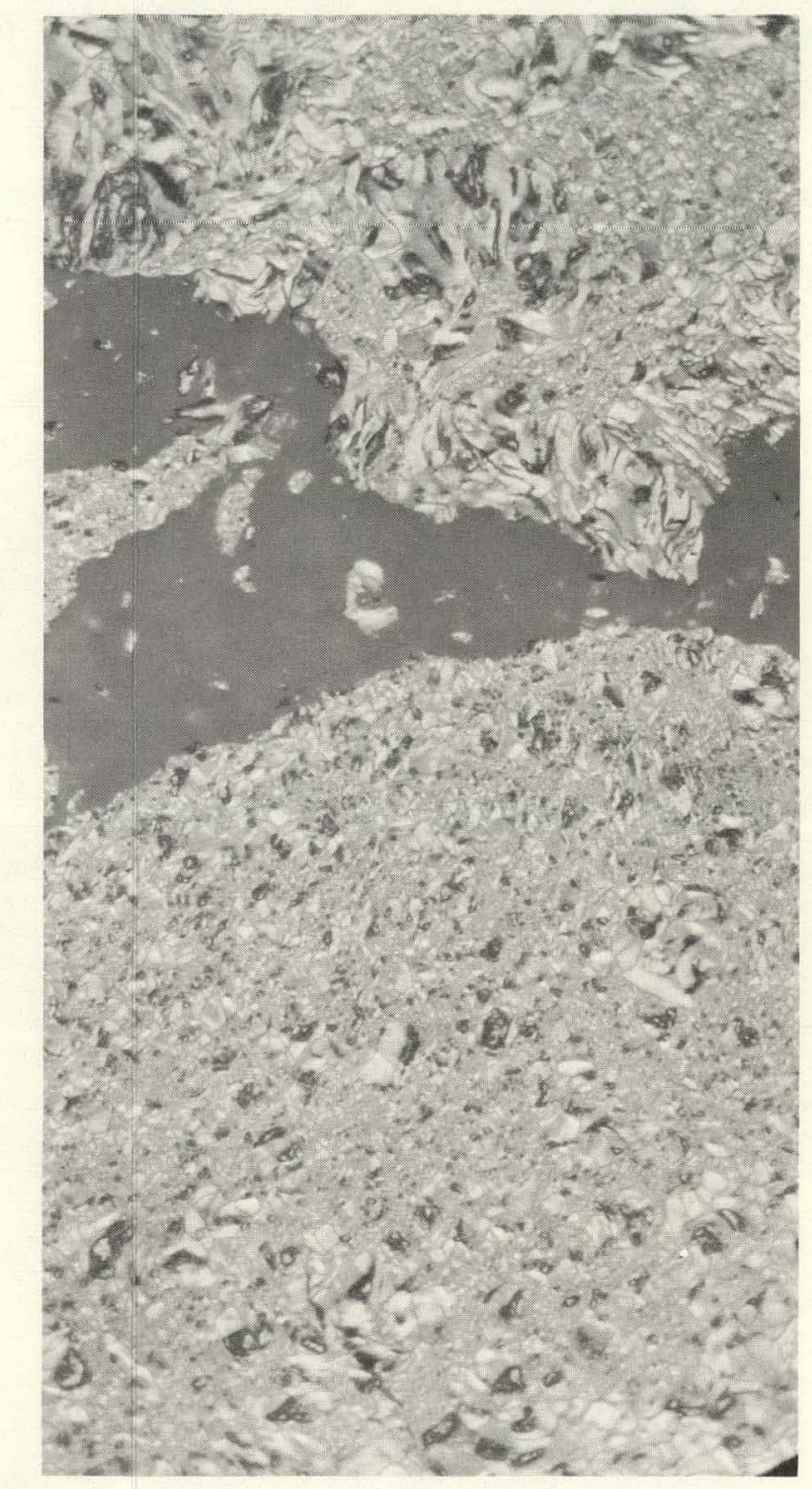

(e) With 1,660 ppm K

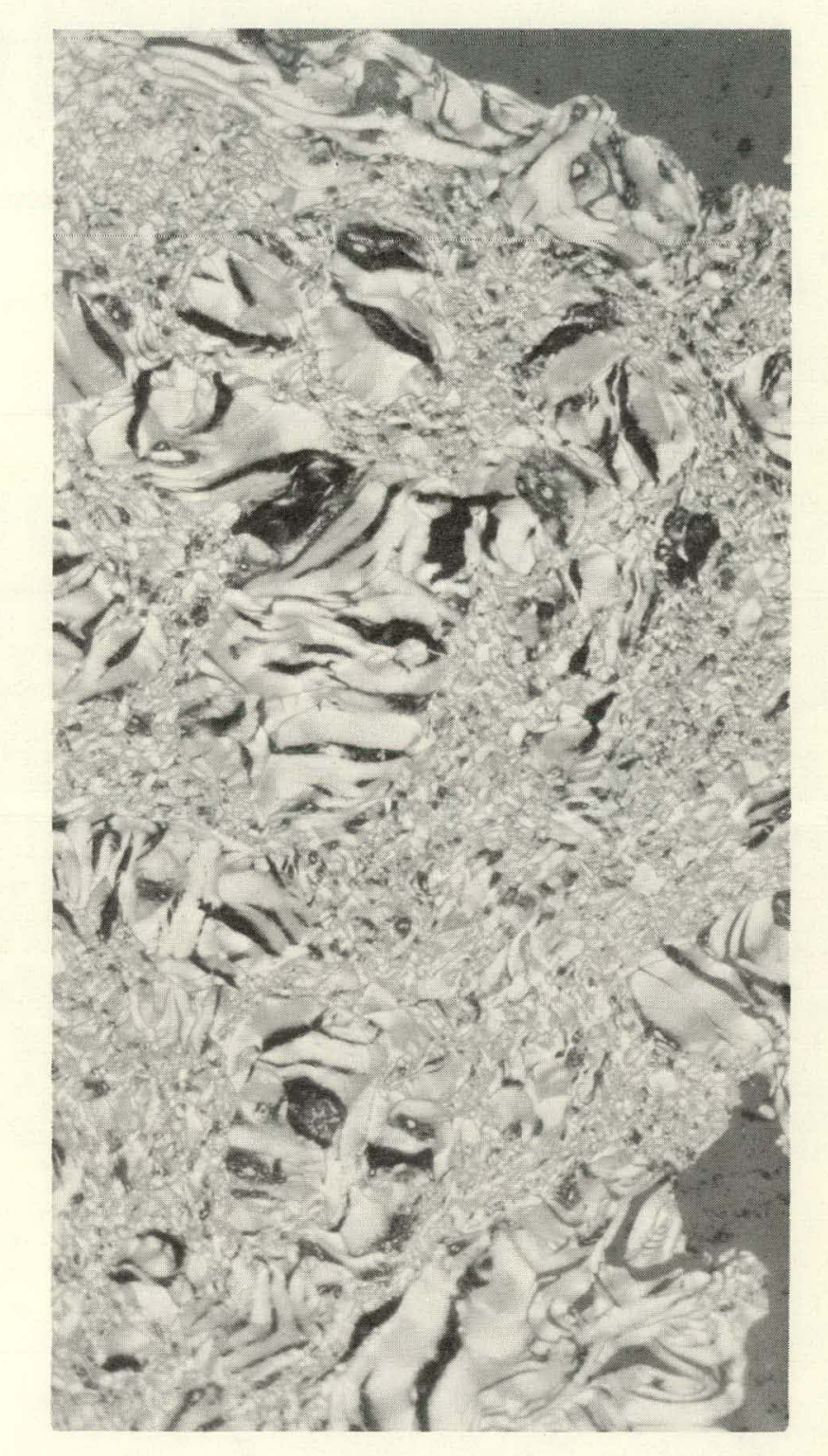

(f) With 40 ppm K 
Table 9

PROPERTIES OF CARBONS DERIVED FROM POLYMERS OF CINNAMYLIDENEINDENE

\begin{tabular}{|c|c|c|c|c|c|c|c|c|c|}
\hline \multirow[b]{3}{*}{$\begin{array}{c}\text { Batch } \\
\text { Number }\end{array}$} & \multicolumn{4}{|c|}{ Polymerization(1) } & \multicolumn{5}{|c|}{ Carbonization } \\
\hline & \multirow{2}{*}{$\begin{array}{c}\text { Autoclave } \\
\text { Temperature } \\
\left({ }^{\circ} \mathrm{C}\right) \\
\end{array}$} & \multirow{2}{*}{$\begin{array}{c}\text { Autoclave } \\
\text { Time } \\
\text { (hrs) }\end{array}$} & \multirow{2}{*}{$\begin{array}{c}\text { Polymer } \\
\text { Melting } \\
\text { Range } \\
(\rho \mathrm{C})\end{array}$} & \multirow{2}{*}{$\begin{array}{l}\text { Average } \\
\text { Molecular } \\
\text { Weight }\end{array}$} & \multirow[b]{2}{*}{ Air Cure (2) } & \multirow{2}{*}{$\begin{array}{c}\text { Coke Yield } \\
\text { After } \\
1,000^{\circ} \mathrm{C} \\
(\%)\end{array}$} & \multicolumn{3}{|c|}{$\begin{array}{c}\text { Properties After } \\
2,800^{\circ} \mathrm{C}\end{array}$} \\
\hline & & & & & & & $\begin{array}{l}\text { d004 } \\
(A)\end{array}$ & $g$ factor & $\begin{array}{l}L_{c} \\
(A)\end{array}$ \\
\hline $\mathrm{H} 2-48 \mathrm{~A}(3)$ & 200 & 2 & $165-205$ & 907 & $\begin{array}{l}\text { No } \\
\text { Yes }\end{array}$ & $\begin{array}{l}41 \\
53\end{array}$ & $\begin{array}{l}1.6825 \\
1.6928\end{array}$ & $\begin{array}{l}0.882 \\
0.635\end{array}$ & $\begin{array}{l}265 \\
101\end{array}$ \\
\hline $2-27-70 \mathrm{~A} 1(4)$ & 200 & 6 & $215-235$ & 1,223 & $\begin{array}{l}\text { No } \\
\text { Yes }\end{array}$ & $\begin{array}{l}40 \\
67(?)\end{array}$ & $\begin{array}{l}1.6851 \\
1.7098\end{array}$ & $\begin{array}{l}0.824 \\
0.282\end{array}$ & $\begin{array}{r}136 \\
82\end{array}$ \\
\hline $\mathrm{H} 2-48 \mathrm{~B}(3)$ & 250 & 2 & $73-95$ & 539 & $\begin{array}{l}\text { No } \\
\text { Yes }\end{array}$ & $\begin{array}{l}41 \\
48\end{array}$ & $\begin{array}{l}1.6822 \\
1.6848\end{array}$ & $\begin{array}{l}0.894 \\
0.824\end{array}$ & $\begin{array}{l}284 \\
165\end{array}$ \\
\hline $2-27-70 \mathrm{BI}(4)$ & 250 & 6 & $110-135$ & 634 & $\begin{array}{l}\text { No } \\
\text { Yes }\end{array}$ & $\begin{array}{l}36 \\
34\end{array}$ & $\begin{array}{l}1.6911 \\
1.6888\end{array}$ & $\begin{array}{l}0.682 \\
0.729\end{array}$ & $\begin{array}{l}111 \\
105\end{array}$ \\
\hline $2-1-70 B(5)$ & 300 & 2 & $60-100$ & 504 & $\begin{array}{l}\text { No } \\
\text { Yes }\end{array}$ & $\begin{array}{l}38 \\
37\end{array}$ & $\begin{array}{l}1.6860 \\
1.6900\end{array}$ & $\begin{array}{l}0.800 \\
0.706\end{array}$ & $\begin{array}{r}147 \\
98\end{array}$ \\
\hline $\mathrm{H} 2-48 \mathrm{C}(3)$ & 300 & 4 & $60-75$ & 451 & $\begin{array}{l}\text { No } \\
\text { Yes }\end{array}$ & $\begin{array}{l}46 \\
54\end{array}$ & $\begin{array}{l}1.6825 \\
1.6894\end{array}$ & $\begin{array}{l}0.882 \\
0.718\end{array}$ & $\begin{array}{l}263 \\
108\end{array}$ \\
\hline $2-27-70 \mathrm{Cl}^{(4)}$ & 300 & 6 & $60-75$ & 379 & $\begin{array}{l}\text { No } \\
\text { Yes }\end{array}$ & $\begin{array}{l}35 \\
41\end{array}$ & $\begin{array}{l}1.6879 \\
1.6903\end{array}$ & $\begin{array}{l}0.753 \\
0.694\end{array}$ & $\begin{array}{l}122 \\
110\end{array}$ \\
\hline $\mathrm{H} 2-48 \mathrm{D}(3)$ & 300 & 10 & $50-75$ & 419 & $\begin{array}{l}\text { No } \\
\text { Yes }\end{array}$ & $\begin{array}{l}47 \\
55\end{array}$ & $\begin{array}{l}1.6820 \\
1.6897\end{array}$ & $\begin{array}{l}0.894 \\
0.718\end{array}$ & $\begin{array}{l}- \\
-\end{array}$ \\
\hline $\mathrm{H} 2-48 \mathrm{E}(3)$ & 340 & 2 & $50-75$ & 434 & $\begin{array}{l}\text { No } \\
\text { Yes }\end{array}$ & $\begin{array}{l}47 \\
57\end{array}$ & $\begin{array}{l}1.6822 \\
1.6900\end{array}$ & $\begin{array}{l}0.894 \\
0.706\end{array}$ & $\begin{array}{l}331 \\
106\end{array}$ \\
\hline $2-22-70 \mathrm{~B}(4)$ & 340 & 6 & $85-115$ & 445 & $\begin{array}{l}\text { No } \\
\text { Yes }\end{array}$ & $\begin{array}{l}58 \\
59\end{array}$ & $\begin{array}{l}1.6894 \\
1.6700\end{array}$ & $\begin{array}{l}0.718 \\
0.706\end{array}$ & $\begin{array}{l}90 \\
99\end{array}$ \\
\hline
\end{tabular}

(1) Samples were heated in a five-liter autoclave at an initial pressure of $300 \mathrm{psi}$.

(2) Air cure consisted of heating to $250^{\circ} \mathrm{C}$ in a programmed cycle covering $\sim 48$ hours.

(3) Samples contained $\sim 500 \mathrm{ppm}$ potassium.

(4) Yotassium content unknown.

(J) Sumple contained $\sim 8 U ̈$ ppm potassium.

in the range from 300 to $350^{\circ} \mathrm{C}$ (as suggested by the minimum molecular weight values shown in Figure 19) and began to increase again when heated at $340^{\circ} \mathrm{C}$ for six hours. As would be expected, changes in the molecular weight of the six-hour samples with increasing autoclave temperature closely parallel the observed change in polymer melting temperatures which also show a minimum. The latter data are depicted in Figure 20.

A correlation between the average molecular weight and the heat-treatment time at constant temperature $\left(300^{\circ} \mathrm{C}\right)$ is seen in Figure 21. As indicated, average molecular weight data describe a minimum at about eight hours. Thus, a minimum-molecular-weight, and minimum-melting material results from autoclave treatment at $300^{\circ} \mathrm{C}$ for $6-8$ hours. This minimum-melting material is of interest for binder applications. 


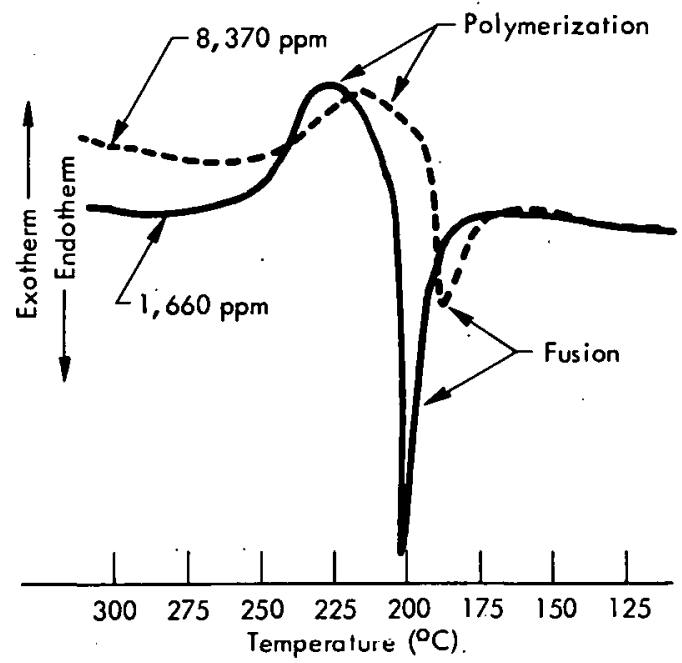

Figure 18. DIFFERENTIAL THERMAL ANALYSIS SCANS OF CINNAMYLIDENEINDENE SAMPLES WITH VARIABLE POTASSIUM CONTENTS. (Heating Rate, $6^{\circ} \mathrm{C} / \mathrm{min}$ )

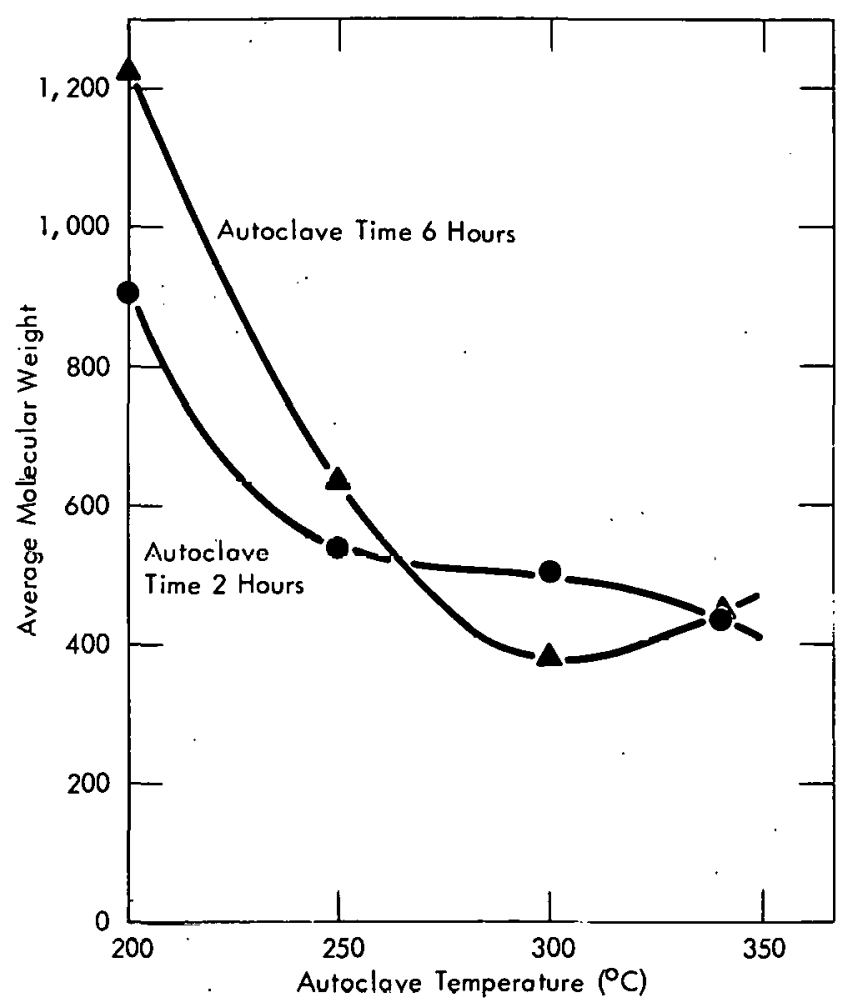

Figure 19. AंVERAGE MOLECULAR WEIGHT OF AUTOOCLAVEPOLYMERIZED CINNAMYLIDENEINDENE AS A FUNCTION OF THE AUTOCLAVE TEMPERATURE. 


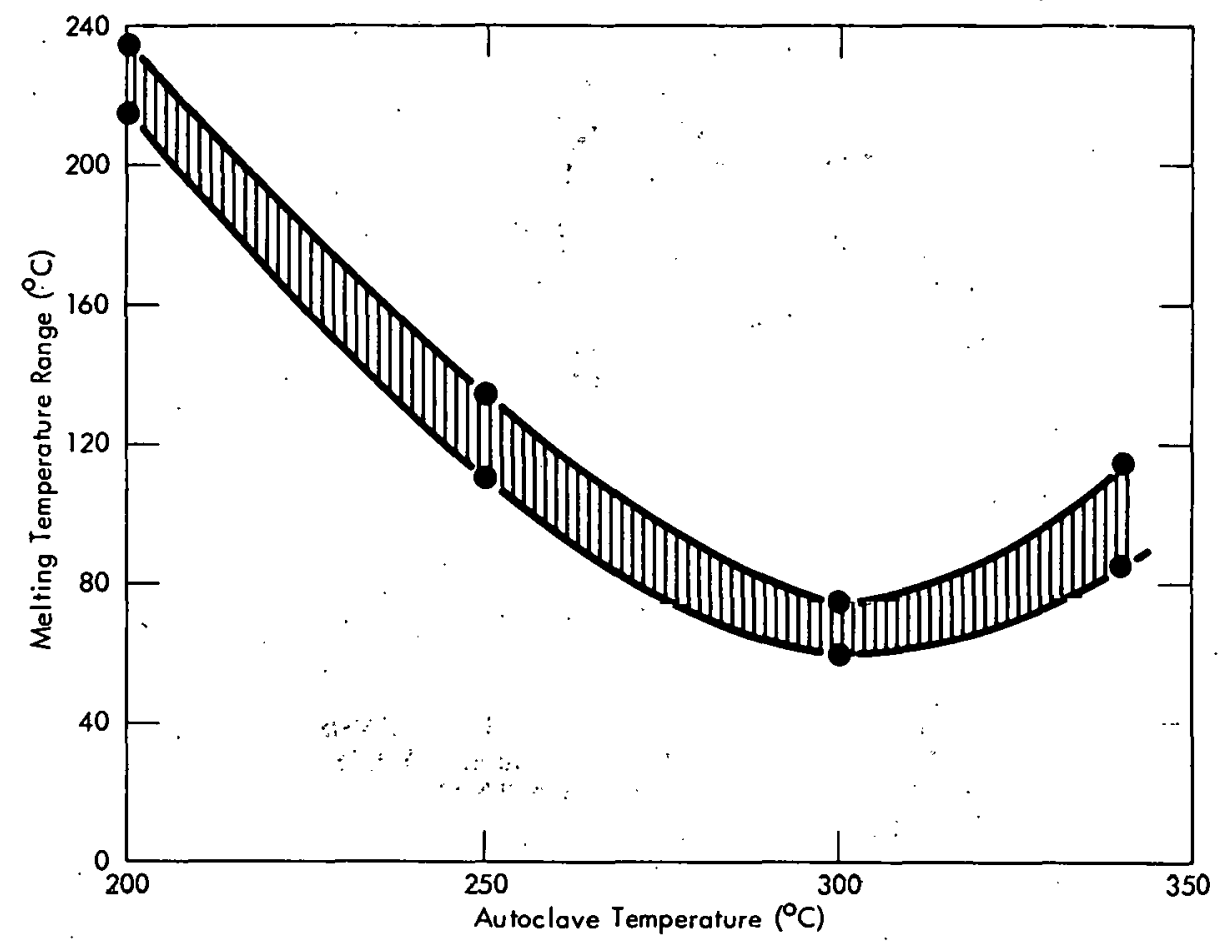

Figure 20. ME LTING TEMPERATURE RANGE OF AUTOCLAVE-POLYMERIZED (6 HOURS) CINNAMYLIDENEINDENE AS A FUNCTION OF THE AUTOCLAVE TEMPERATURE.

Molecular distributlons of polymers corresponding to various autoclave temperatures are shown in Figure 22. A general shift in the distribution toward regions of lower molecular weights with increasing autoclave temperature was iil suppurt of trends in the average molecular weight and melting data that were previously cited.

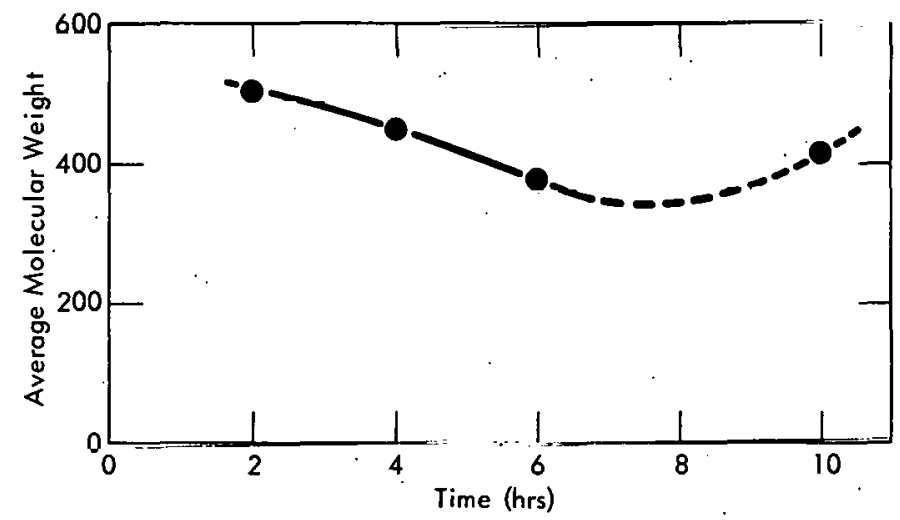

Figure 21. AVERAGE MOLECULAR WEIGHT OF AUTOCLAVEPOLYMERIZED (AT $300^{\circ} \mathrm{C}$ ) CINNAMYLIDENEINDENE AS A FUNCTION OF THE AUTOCLAVE HEAT -TREATMENT TIME. 


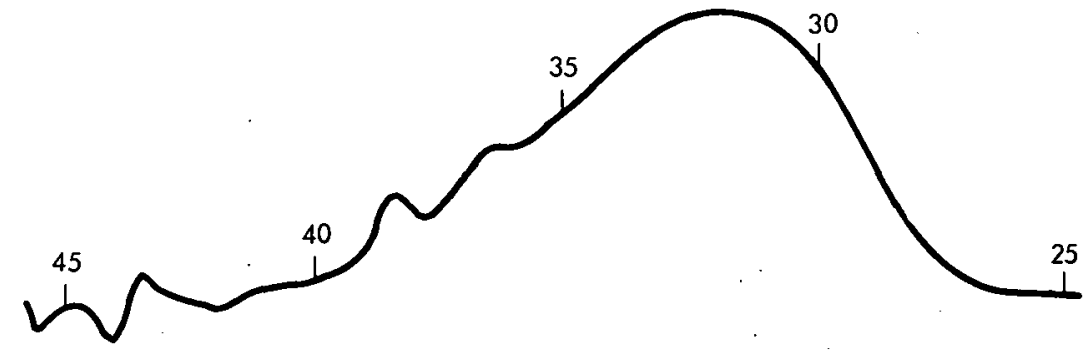

(a) At $200^{\circ} \mathrm{C}(4 \mathrm{X})$

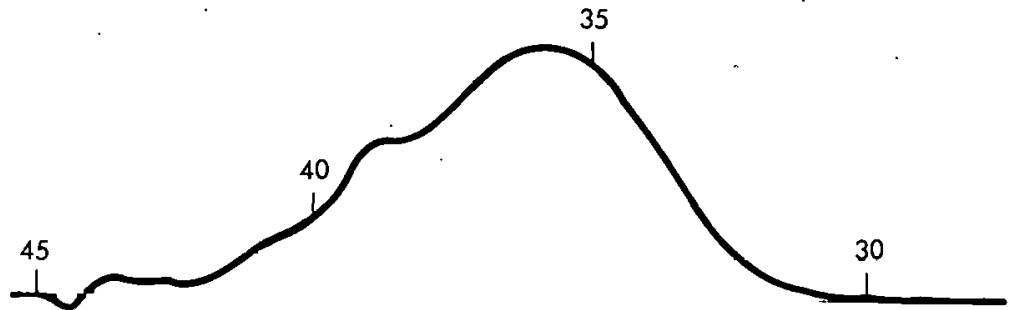

(b) At $250^{\circ} \mathrm{C}(2 \mathrm{X})$

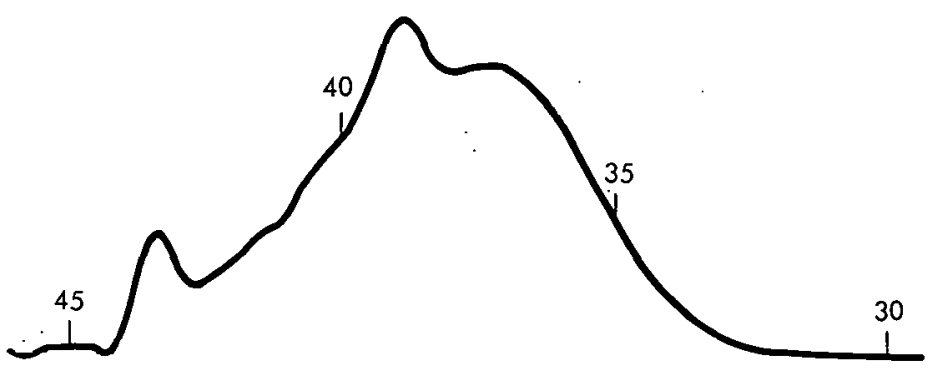

(c) At $300^{\circ} \mathrm{C}(2 \mathrm{X})$

$$
\begin{aligned}
& \text { (Increasing Molecular Weight } \longrightarrow \text { Elution Volumes (1 elution volume }=5 \mathrm{ml} \text { ) } \\
& \text { ( })
\end{aligned}
$$

Figure 22. GEL PERMEATION CHROMATOGRAPHY SCANS SHOWING THE MOLECULAR DISTRIBUTION OF CINNAMYLIDENEINDENE AFTER AUTOCLAVE POLYMERIZATION (6 HOURS).

Coke-yield data for the various autoclave-polymerized CAl samples are included in Table 9. Coke yields of samples that were heated for two and six hours are shown in Figure 23 as a function of the autoclave temperature. In general, coke yields observed for the $300^{\circ} \mathrm{C}$ samples were lower than those for samples autoclaved at lower or higher temperatures. These data would agree with that showing minimum molecular weight values for the $300^{\circ} \mathrm{C}$ samples. The highest coke-yield values for CAI (either in monomer or polymer forms) were observed for samples heated at $340^{\circ} \mathrm{C}$. The effect of an air cure on coke yields of CAl polymers was difficult to evaluate from the data shown in Figure 23. Though correlations were somewhat obscure, an air cure seemed to have a positive effect on the coke yields of samples heated for two hours, but coke yields of the six-hour samples seemed almost independent of the curc conditions. 


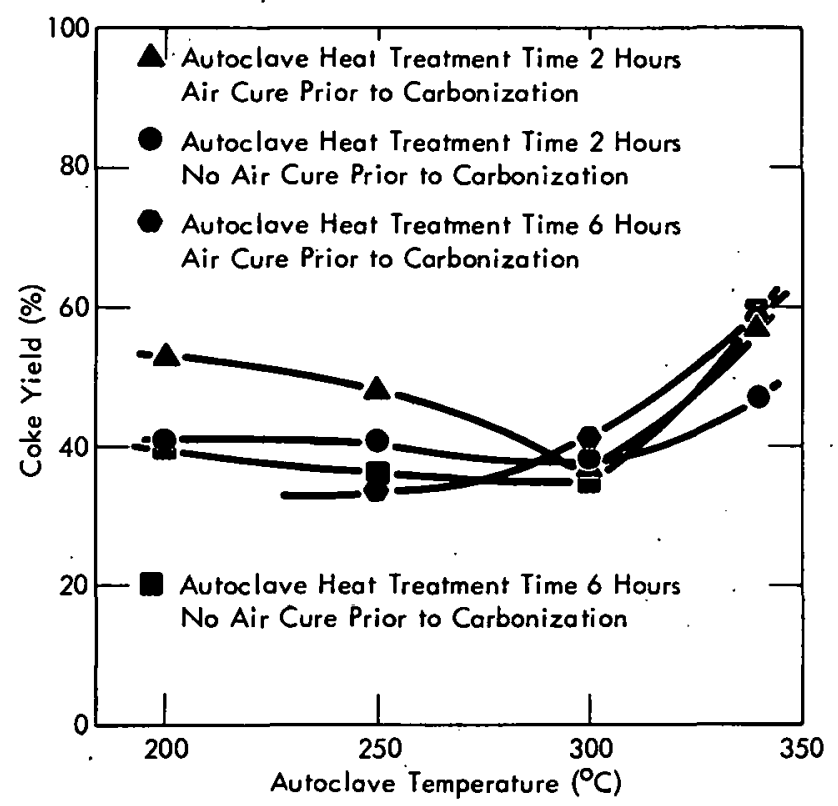

Figure 23. COKE YIELDS (AFTER $1,000^{\circ} \mathrm{C}$ ) OF AUTOCLAVE POLYMERIZED CINNAMYLIUENEINDENE AS A FUNCTION OF THE AUTOCLAVE TEMPERATURE.

Properties of carbons derived from the CAl polymers are included in Table 9. Correlations of carbon properties with autoclave conditions were not possible from these data since samples were known to have a variable potassium content. The latter factor probably influences the carbon properties to a greater degree than the autoclave polymerization conditions. Another factor which influences the properties of carbon derived from CAI polymers is the cure conditions prior to carbonization. This relationship is obvious from the data in Table 9 which show higher $d_{004}$ values and lower $L_{c}$ values for samples which received an air cure prior to carbonization. Thus, a prior air cure tends to decrease the graphiticity of carbon derived from CAI.

Oxidative Polymerization - A second method used to polymerize CAl involved heating samples at 250 or $300^{\circ} \mathrm{C}$ with air or oxygen gas bubbling through the molten material (see diagram of the apparatus in Figure 3). Table 10 lists the data that were obtained on heating $\mathrm{CAl}$ at $250^{\circ} \mathrm{C}$ with an oxygen gas flow rate of $84 \mathrm{cc} / \mathrm{mln}$. Samples were taken periodically for evaluation. The increase in viscosity (as measured at $250^{\circ} \mathrm{C}$ ) with heating time is depicted in Figure 24 which shows an almost linear rate of increase for the initial 45 hours, after which the rate increases significantly. Figure 25 shows the correlation between the viscosity and oxygen content of the polymer. As noted, viscosity increases markedly for relatively small increases in the oxygen content. The high oxygen content recorded in Table 10 for the starting CAl material reflects the presence of oxygen-containing impurities, such as cinnamaldehyde 
Table 10

PROPERTIES OF CINNAMYLIDENEINDENE AND CINNAMYLIDENEINDENE-DERIVED CARBON

AS A FUNCTION OF THE HEAT-CURE CONDITIONS

\begin{tabular}{|c|c|c|c|c|c|c|c|c|}
\hline \multirow[b]{2}{*}{$\begin{array}{c}\text { Sample } \\
\text { Number (1) }\end{array}$} & \multirow{2}{*}{$\begin{array}{c}\text { Heat-Cure } \\
\text { Time } \\
\text { (hrs) }\end{array}$} & \multirow[b]{2}{*}{$\begin{array}{l}\text { Viscosity }(2) \\
\text { (centipoises) }\end{array}$} & \multirow{2}{*}{$\begin{array}{c}\text { Oxygen } \\
\text { Content }(3) \\
(\%)\end{array}$} & \multirow{2}{*}{$\begin{array}{l}\text { Melting } \\
\text { Point } \\
(0 \mathrm{C})\end{array}$} & \multirow{2}{*}{$\begin{array}{l}\text { Coke Yield } \\
\text { After } \\
1,000^{\circ} \mathrm{C}(4) \\
(\%)\end{array}$} & \multirow{2}{*}{$\frac{\text { Properties }}{\mathrm{d}_{004}}$} & \multicolumn{2}{|c|}{ After $2,800^{\circ} \mathrm{C}$} \\
\hline & & & & & & & g. factor & $\begin{array}{l}L_{c} \\
\text { (A) }\end{array}$ \\
\hline $\mathrm{A} 2$ & 0 & - & 1.0 & $172-190$ & 40 & 1.6992 & 0.994 & - \\
\hline$\dot{\mathrm{B}}$ & 4 & 102 & 0.4 & $110-123$ & 43 & 1.6834 & 0.859 & 207 \\
\hline c & 21 & 174 & 0.60 & $120-150$ & 50 & 1.6842 & 0.847 & 170 \\
\hline D & 29 & 200 & 0.6 & $120-150$ & 49 & 1.6857 & 0.812 & 152 \\
\hline$E$ & 45 & 261 & 0.7 & $122-155$ & 51 & 1.6860 & 0.800 & 142 \\
\hline$F$ & 52 & 340 & 0.8 & $140-170$ & 49 & 1.6868 & 0.776 & 132 \\
\hline
\end{tabular}

(1) Cinnamylideneindene was heated at $250^{\circ} \mathrm{C}$ with constant agitation and with oxygen bubbling through the molten material at a flow rate of $84 \mathrm{cc} / \mathrm{min}$.

(2) Viscosity was measured at $250^{\circ} \mathrm{C}$; agitation and oxygen flow stopped during viscosity measurement .

(3) Oxygen content determined by neutron activation.

(4) Calculation of coke yields did not include material loss during the heat treatment.

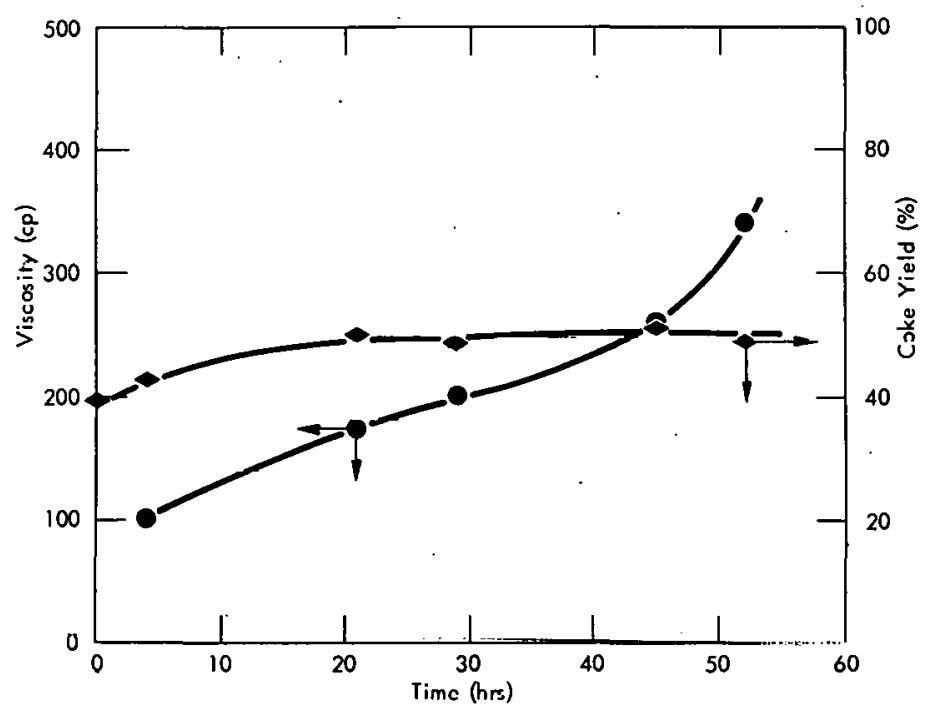

Figure 24. VISCOSITY AND COKE YIELD OF CINNAMYLIDENEINDENE AS A FUNCTION OF THE HEAT-TREATMENT TIME AT $250^{\circ} \mathrm{C}$ IN THE PRESENCE OF OXYGEN GAS.

and methanol, which are lost as volatiles during the early stages of heating. The change in molecular distribution effected by four hours of heating is shown in Figure 26. As stated previously, polymerization of CAl occurs quite rapidly at temperatures around $200^{\circ} \mathrm{C}$.

Coke-yield values of the polymeric samples were quite constant with heating time after the first ten hours. Calculations of these values did not include 


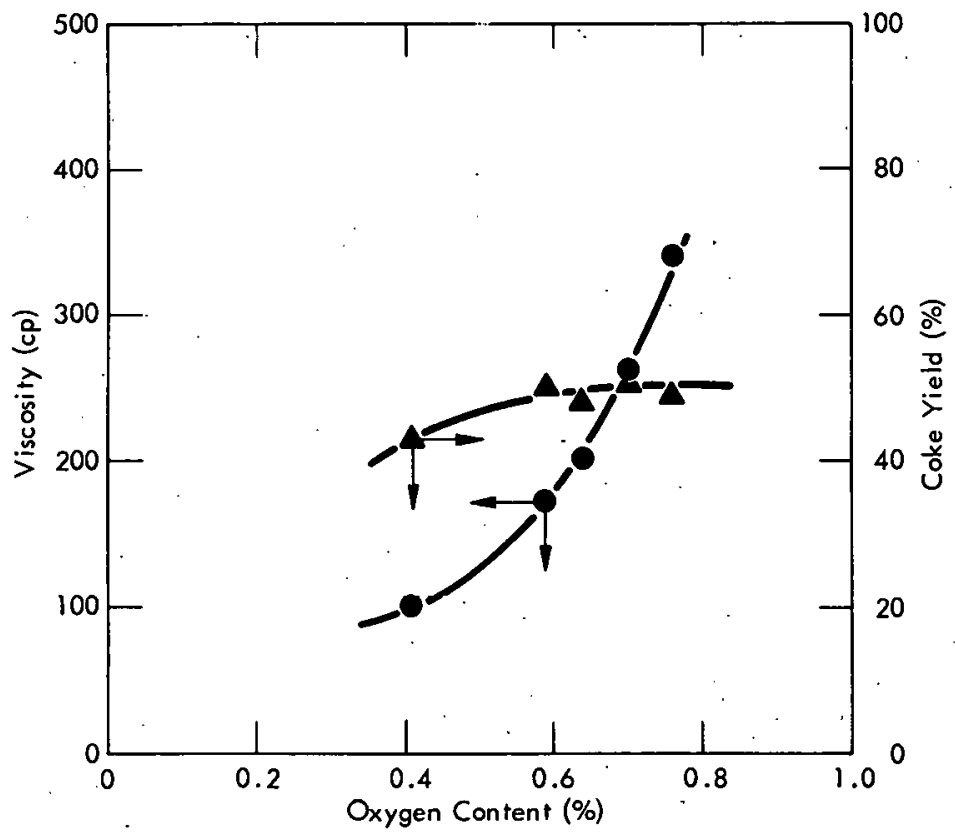

Figure 25. VISCOSITY AND COKE YIELD OF CINNAMYLIDENEINDENE AS A FUNCTION OF THE OXYGEN CONTENT ON HEAT TREATMENT AT $250^{\circ} \mathrm{C}$ IN THE PRESENCE OF OXYGEN GAS.

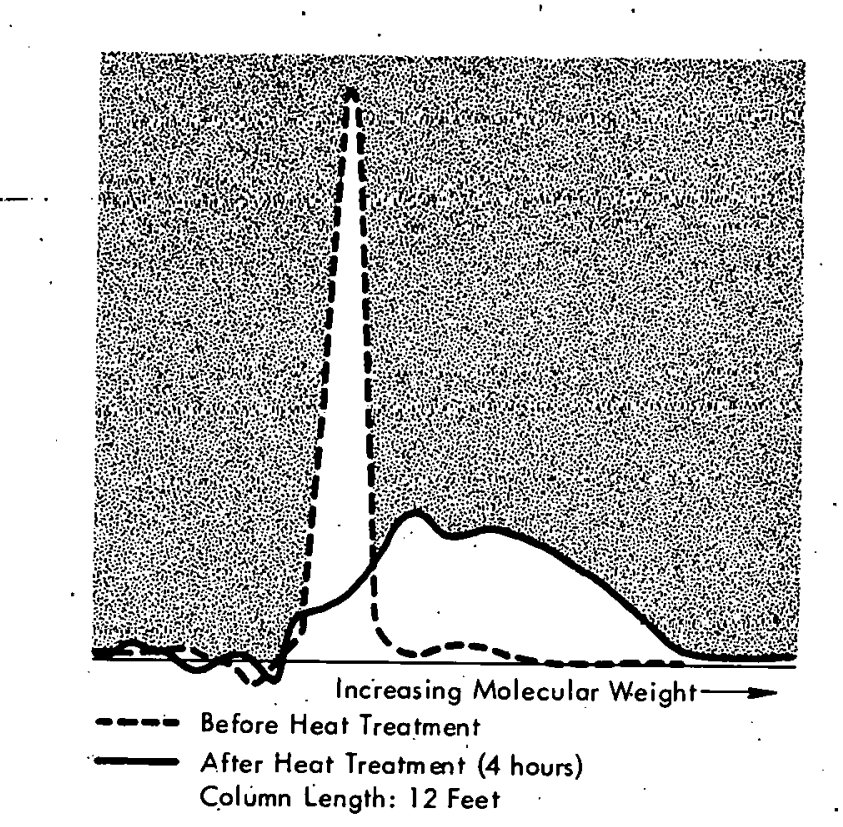

Figure 26. GEL PERMEATION CHROMATOGRAPHY SCANS SHOWING THE MOLECULAR DISTRIBUTION OF CINNAMYLIDENEINDENE BEFORE AND AFTER HEAT TREATMENT AT $250^{\circ} \mathrm{C}$ IN THE PRESENCE OF OXYGEN GAS. 
the material loss associated with the heat treatment and thus reflect the coke yields of the resulting polymers. Though other properties listed in Table 10 continued to change with time, coke yields seem not to be enhanced by heating times above ten hours. The correlation of coke yields with heating time and oxygen content can be seen in Figures 24 and 25, respectively.

Graphitic properties of carbons derived from the CAI polymers are included in Table 10. Though not determined, the potassium content should be constant for all samples shown in Table 10; and, thus, changes in the graphitic properties can be correlated with the heat-treatment conditions. As indicated in Figure 27, graphitic properties tend to decrease with increasing viscosity and heating time. Microstructures of the carbons, as shown in Figure 28, were quite similar but did reflect a slight decrease in grain size with increasing heating times.

An additional experiment consisted of heating CAI at $300^{\circ} \mathrm{C}$ for six hours with an air-flow rate of $360 \mathrm{cc} / \mathrm{min}$. The resulting polymer had an average molecular weight of 625 and a coke yield of 58 percent. In comparison, a sample of CAI that was heated under argon at $300^{\circ} \mathrm{C}$ for two hours had an average molecular weight of 551 and a coke yield of 47 percent.

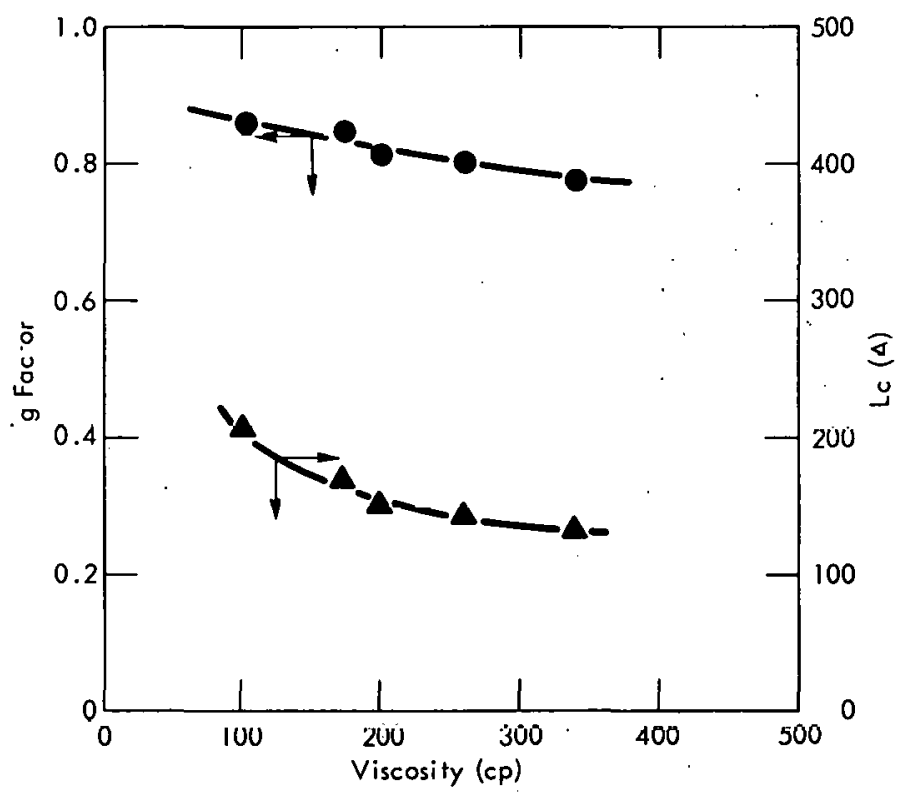

Figure 27. GRAPHITICITY G FACTOR) AND CRYSTALLITE SIZE (L OF CARBON SAMPLES DERIVED FROM CINNAMYLIDENEINDENE AS A FUNCTION OF THE PRECURSOR VISCOSITY (MEASURED AT $250^{\circ} \mathrm{C}$ ) RESULTING FROM HEAT TREATMENT AT $250^{\circ} \mathrm{C}$ IN THE PRESENCE OF OXYGEN GAS. 
Though some control over the graphitic properties can be realized by controlling the conditions during oxidative heat cures, the data in Table 10 show that the changes were small for the heating times expended.

Effect of Pyromellitic Dianhydride (PMDA) on the Properties of CAI-Derived Carbon - The structure of PMDA is such that thermal degradation results in the production of benzyne intermediates which are highly reactive materials and, therefore, have a relatively short existence, thus:

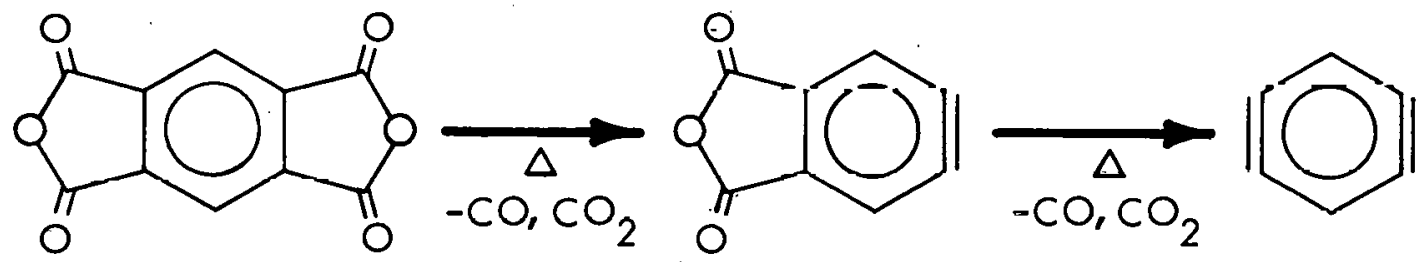

It is not known whether this decomposition of PMDA is sequential or simultaneous. The DTA scan shown in Figure 29 suggests that decomposition occurs over a relatively narrow temperature range. As also noted in Figure 29, an endothermic response occurs around $100^{\circ} \mathrm{C}$ and probably indicates the evolution of water. A slight loss in weight (3\%) accompanied this response. The endothermic response between 220 and $290^{\circ} \mathrm{C}$ is indicative of melting, but suggests a relatively impure sample. Practical grades of PMDA melt at $285-290^{\circ} \mathrm{C}$. The shoulder at approximately $230^{\circ} \mathrm{C}$ suggests the presence of a dihydrate of pyromellitic acid $\left(\mathrm{mp}=242^{\circ} \mathrm{C}\right)$. Included in the broad endothermic response between 220 and $290^{\circ} \mathrm{C}$ could also be anhydrous pyromellitic acid $\left(m p=272^{\circ} \mathrm{C}\right)$. The relatively sharp endothermic response at 300 to $310^{\circ} \mathrm{C}$ was taken as the temperature of degradation of PMDA which would be accompanied by the evolution of considerable quantities of carbon monoxide and carbon dioxide. Products formed when PMDA degrades and when the resulting benzyne intermediates polymerize are apparently volatile or degrade at higher temperatures since no carbon residue was observed when PMDA was heated to carbonization temperatures. However, the nature of PMDA would allow it to function effectively as a crosslinking agent.

The addition of PMDA to CAI had a significant effect on the coke yields and properties of the derived carbons. Data obtained for various CAI-PMDA mixtures are summarized in Table 11. The potassium content in the CAl was not determined, but would be constant for each sample. The graphitic properties of the sample containing no PMDA suggests a relatively low (<1,000 ppm) potassium content. Data in Table 11 show the changes in properties that can be attributed to the presence of PMDA. As indicated in Figure 30, coke-yield 


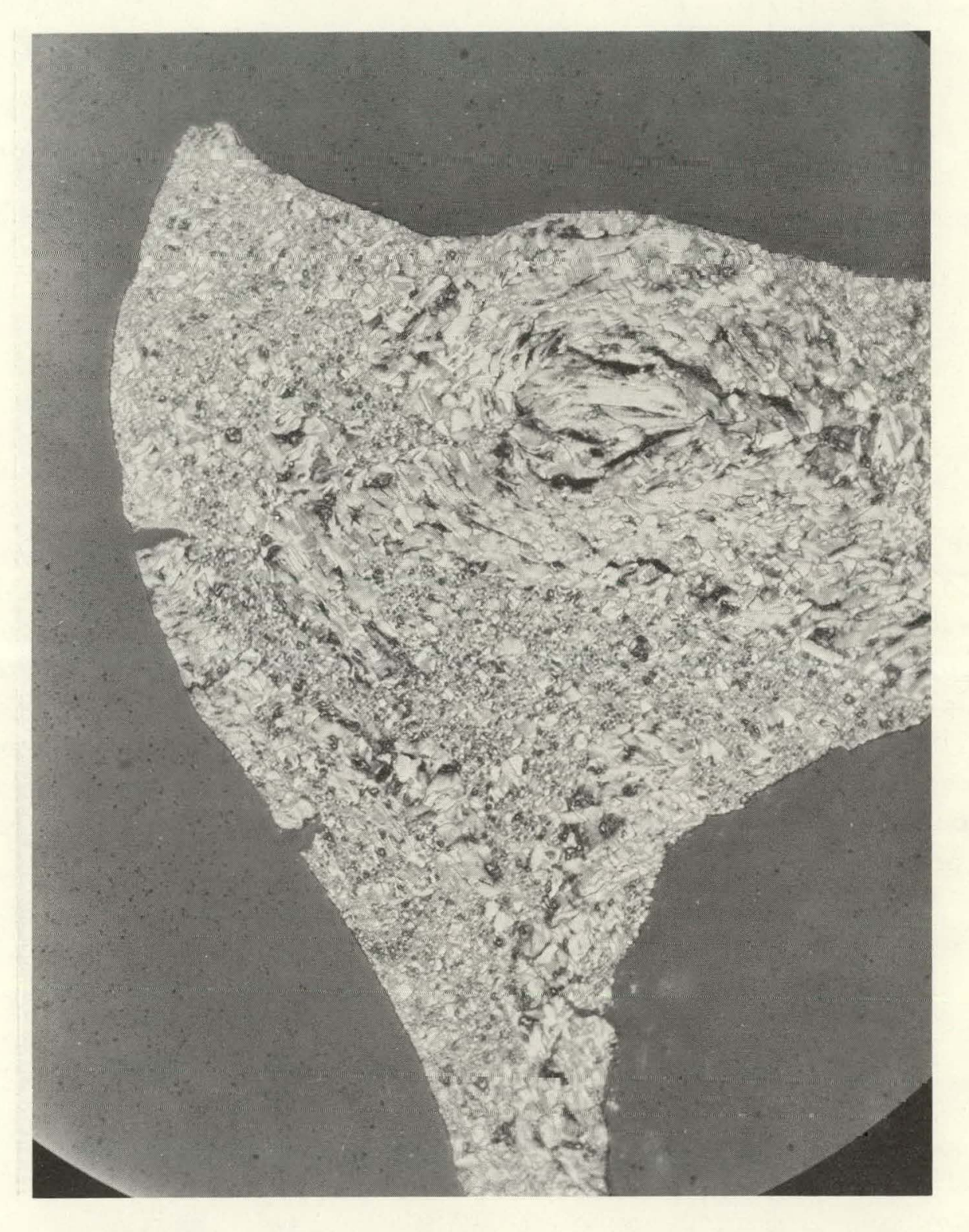

(a) After 4 Hours

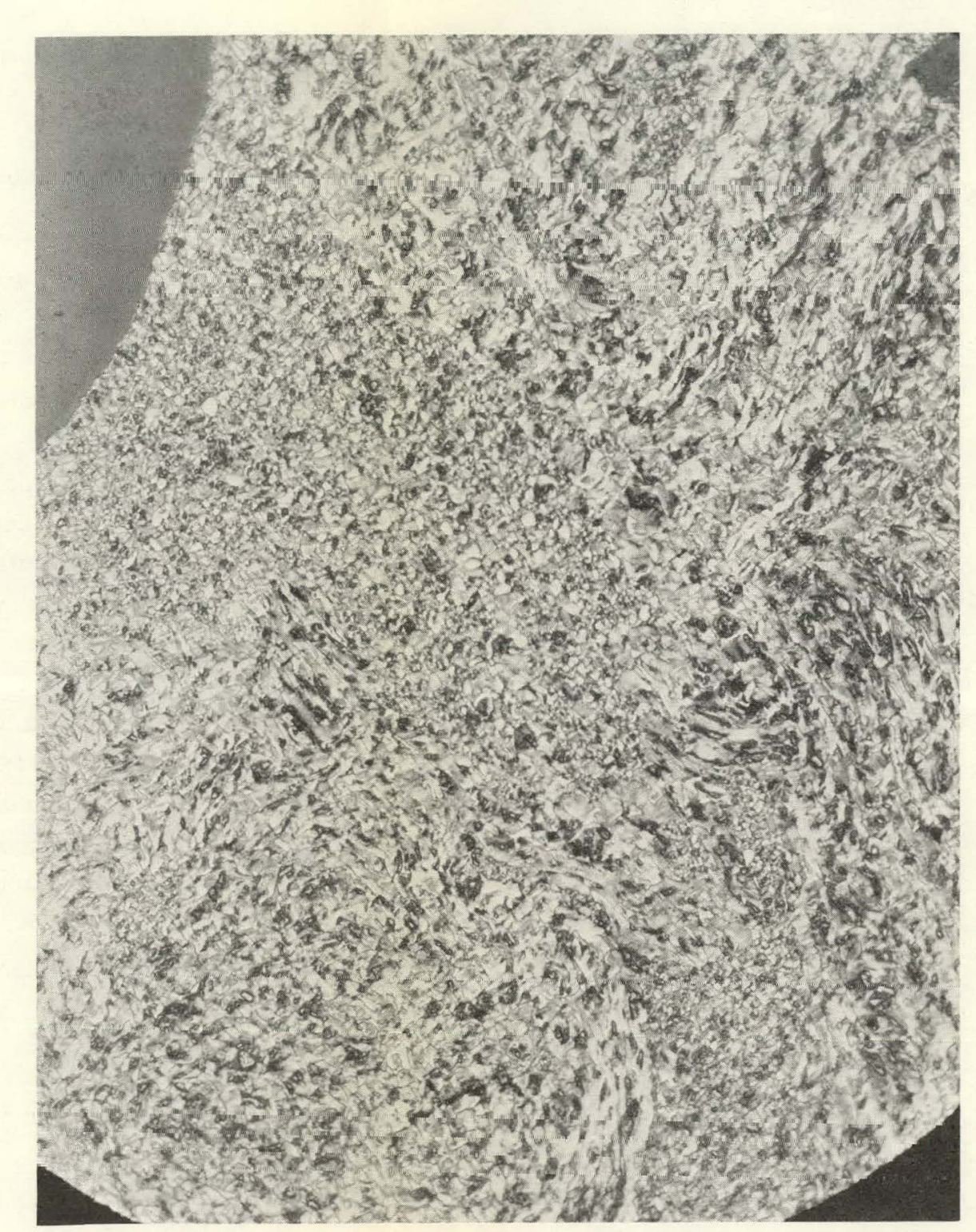

(b) After 21 Hours

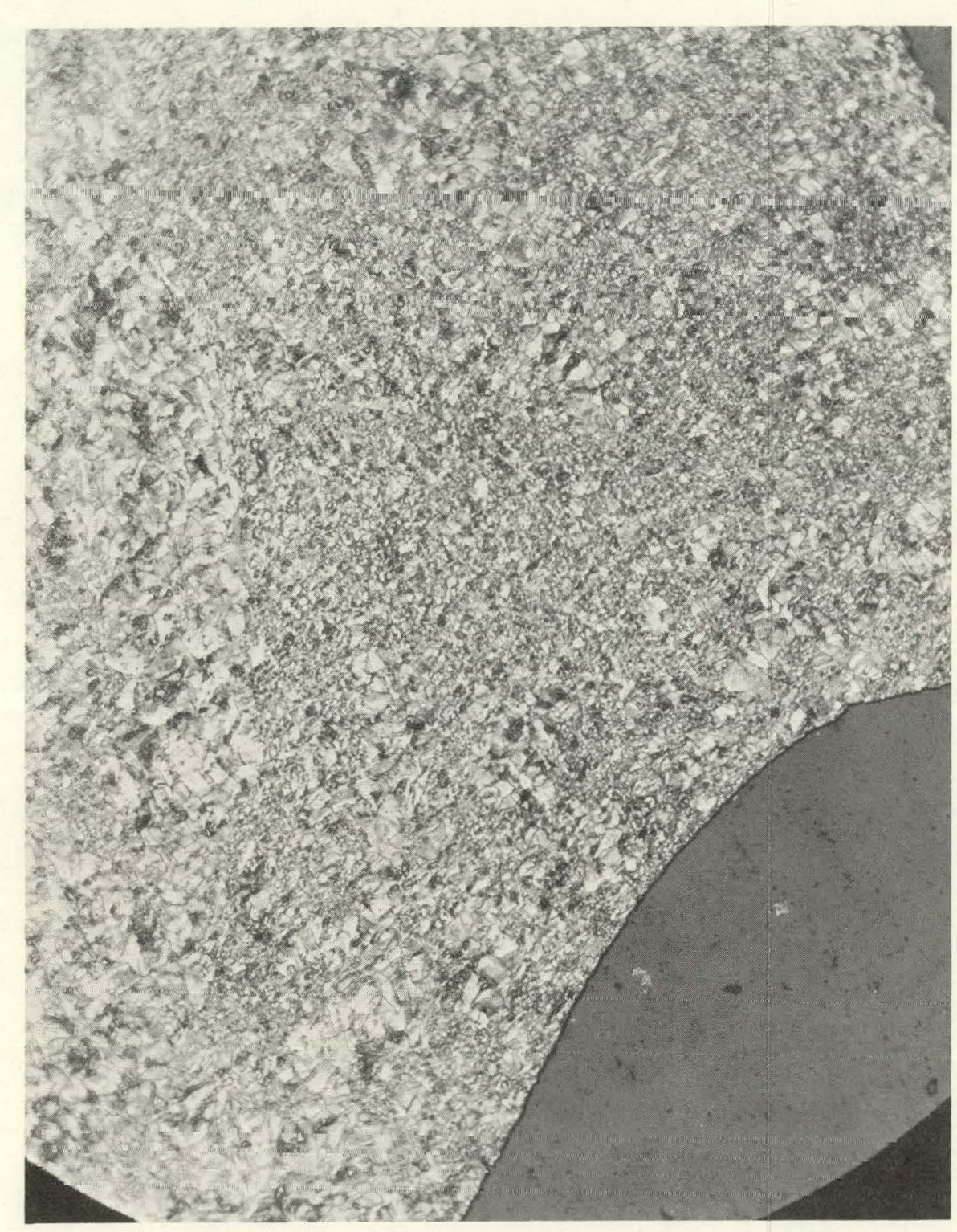

F985-6

Figure 28. MICROSTRUCTURES OF CARBON SAMPLES (AFTER 2,8000 C) DERIVD FROM CINNAMYLIDENEINDENE
THAT WAS HEAT TREATED AT 250 C IN THE PRESENCE OF OXYGEN GAS. (250X)

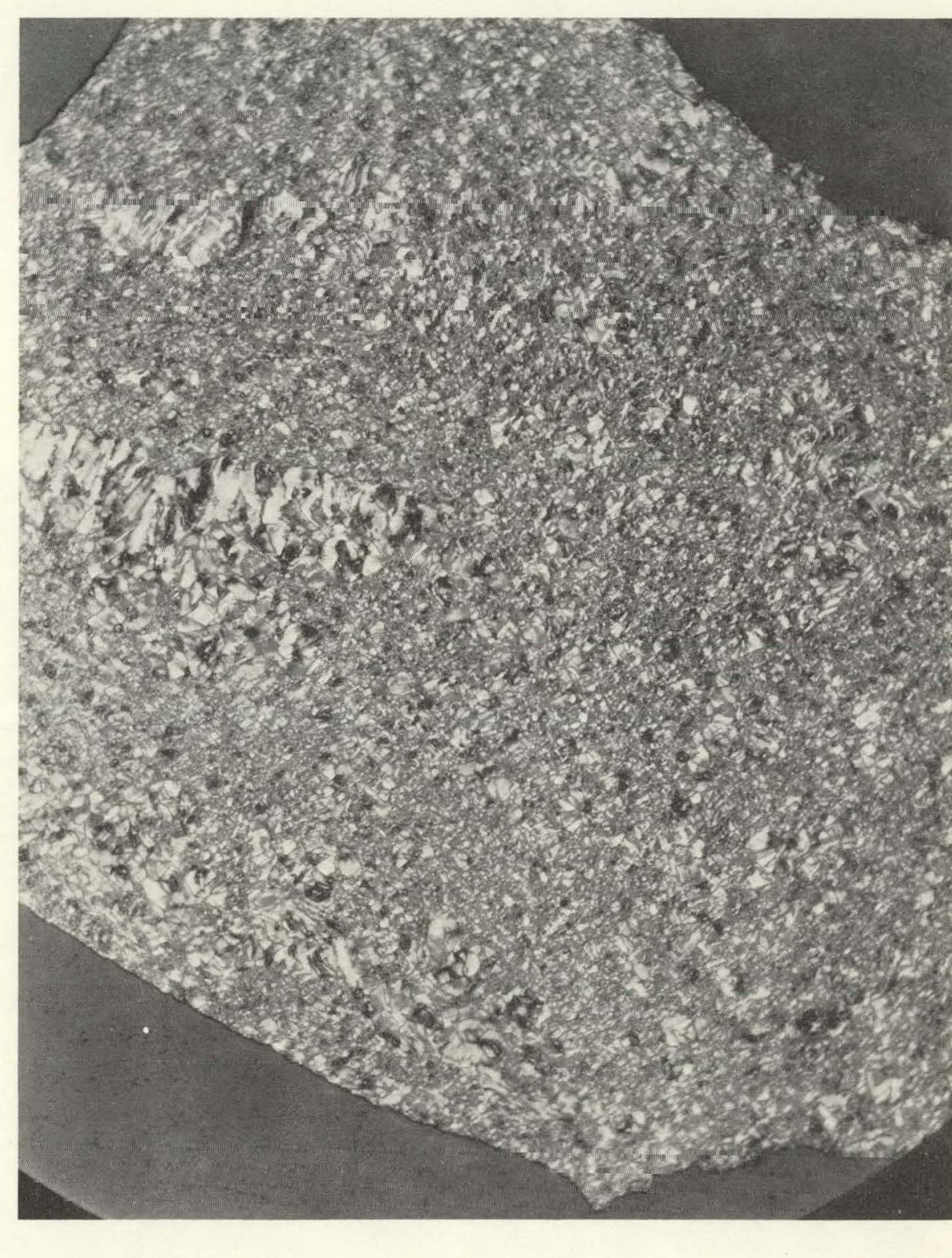

(d) After 52 Hours 


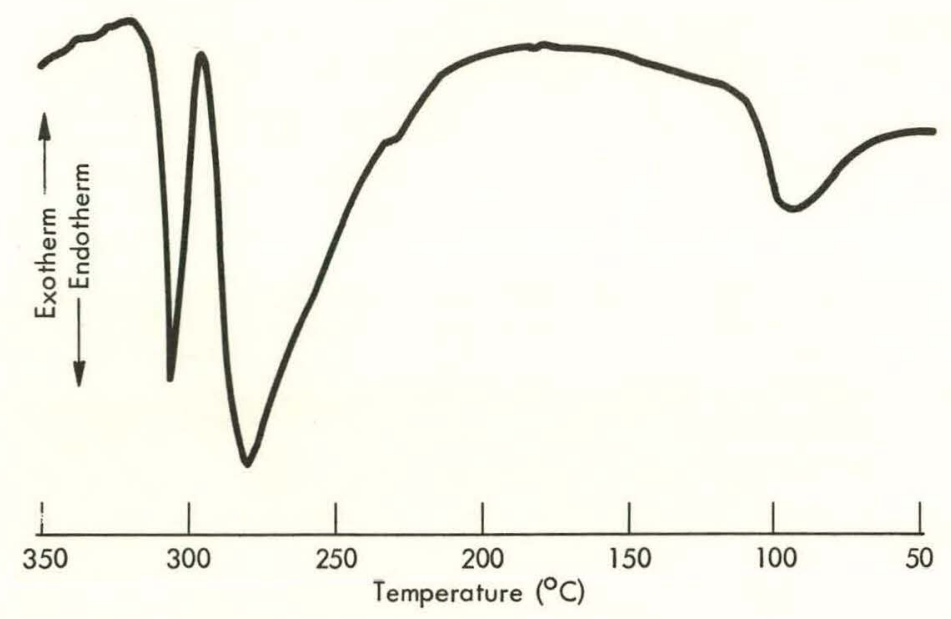

Figure 29. DIFFERENTIAL THERMAL ANALYSIS SCAN OF PYROMELLITIC DIANHYDRIDE. (Heating Rate, $6^{\circ} \mathrm{C} / \mathrm{min}$ )

values pass through a maximum with increasing PMDA content. The maximum occurs at approximately 30 percent PMDA content, which probably represents the composition with maximum interaction between CAI and PMDA. Also shown in Figure 30 is the decrease in graphitic properties that result from the presence of PMDA. At PMDA contents higher than 20 percent, nongraphitic carbon results, indicating a high degree of crosslinking and/or nonplanarity in the polymeric precursors. $\Delta$ transition in the microstructural properties of the carbons is indicated in Figure 31. Significant changes in the microstructure occur for samples with 10 to 20 percent PMDA content; and, thus, some control over the composition in this range should permit a control of the carbon properties.

Table 11

PROPERTIES OF CARBON DERIVED FROM CINNAMYILIDENEINDENEPYROMELLITIC DIANHYDRIDE MIXTURES

\begin{tabular}{|c|c|c|c|c|c|}
\hline \multirow[b]{2}{*}{$\begin{array}{l}\text { Sample } \\
\text { Number }\end{array}$} & \multirow{2}{*}{$\begin{array}{c}\text { PMDA } \\
\text { Content } \\
(\%)\end{array}$} & \multirow{2}{*}{$\begin{array}{c}\text { Coke Yield } \\
\text { After } \\
1,000^{\circ} \mathrm{C} \\
(\%)\end{array}$} & \multicolumn{3}{|c|}{ Properties After $2,800^{\circ} \mathrm{C}$} \\
\hline & & & $\begin{array}{c}\mathrm{d}_{004} \\
(\mathrm{~A})\end{array}$ & $\mathrm{g}$ factor & $\begin{array}{r}L_{C} \\
(A)\end{array}$ \\
\hline $1-93-70 A$ & 0 & 39 & 1.6820 & 0.894 & 281 \\
\hline $1-93-70 B$ & 5 & 40 & 1.6836 & 0.859 & 226 \\
\hline $1-93-70 C$ & 10 & 47 & 1.6851 & 0.824 & 169 \\
\hline $1-93-70 D$ & 20 & 54 & 1.6943 & 0.600 & 101 \\
\hline $1-94-70 A$ & 30 & 60 & Nongraphitic & - & - \\
\hline $1-94-70 B$ & 50 & 48 & Nongraphitic & - & - \\
\hline $1-94-70 C$ & 75 & 35 & Nongraphitic & - & - \\
\hline $1-94-70 D$ & 100 & 4 & Nongraphitic & - & - \\
\hline
\end{tabular}


In summation, the addition of PMDA to CAI increases the coke yields significantly and decreases the graphitizability of the carbon. Similar results were observed for other indene derivatives containing PMDA, as will be discussed in other parts of this report. It would appear that this approach to the control of graphitic properties has merit, and should be evaluated for other precursor materials.

Truxene

Truxene (TX) is a high-melting $\left(\sim 370^{\circ} \mathrm{C}\right)$ material derived from indene, and tends to produce a nongraphitic carbon. The structure of truxene is:

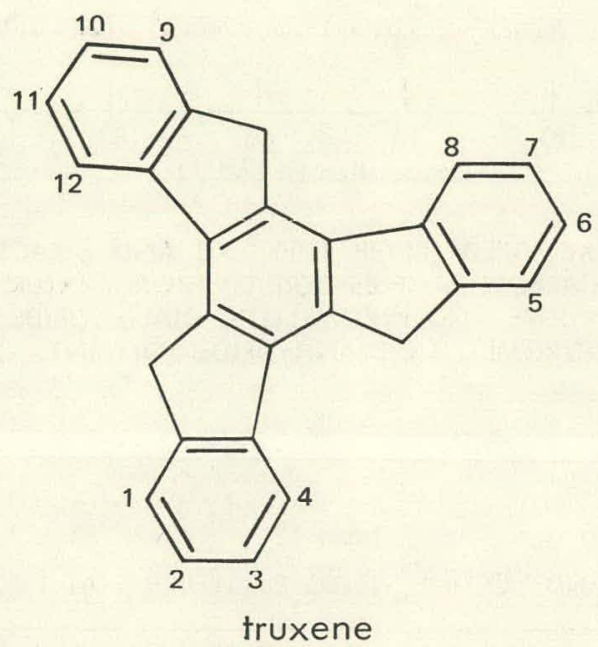

The symmetrical arrangement of three indene units which combine to form a new aromatic nucleus can be visualized. The thermal properties of truxene are portrayed in Figure 32, which indicate polymerization at approximately $500^{\circ} \mathrm{C}$. Samples of truxene that were heated isothermally under inert gas at $400^{\circ} \mathrm{C}$ were observed not to lose their crystallinity. However, samples were converted into an amorphous pitch by heating at $425^{\circ} \mathrm{C}$ for four hours. Polymerization is apparently accompanied by significant crosslinking and/or formation of nonplanar intermediates, resulting in a polymer with physical properties not conducive to molecular orientation, and thus a carbon not amenable to subsequent graphitization.

Weight and volume yields of a series of TX products are reported in Table 12. As is evident, coke yields were increased significantly by use of an air cure prior to carbonization. Volume yields of these samples were calculated using coke-yield data and mass-density-volume relationships (see Page 15). 


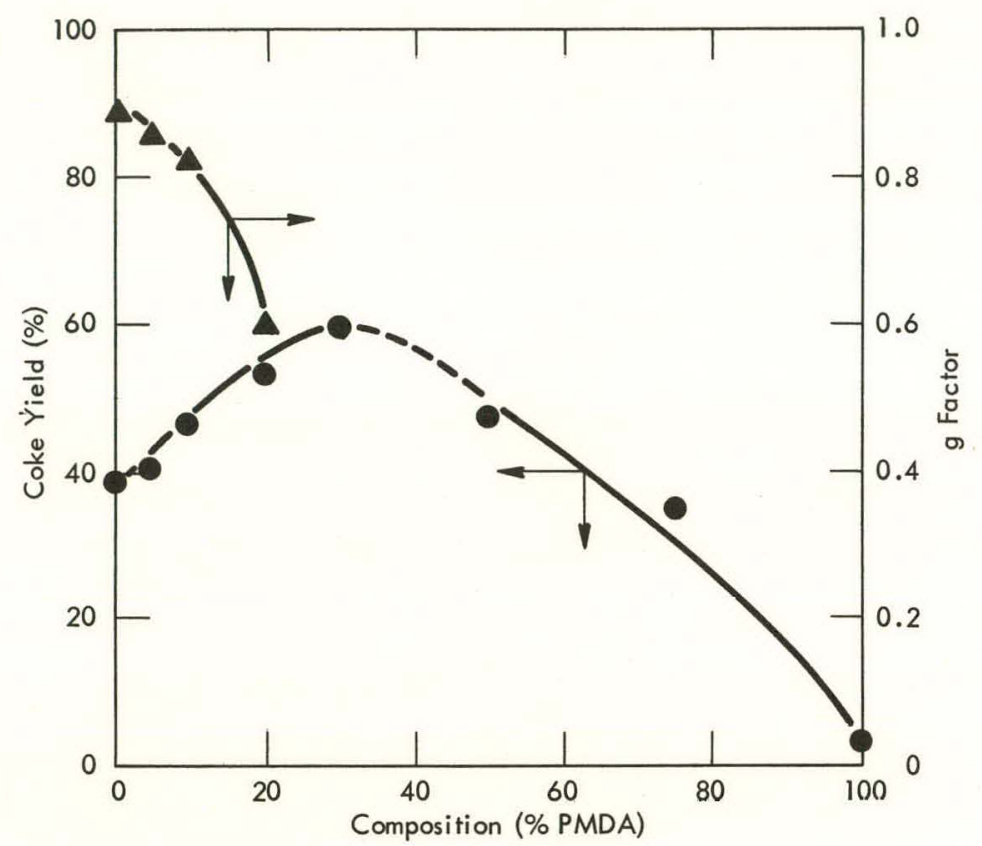

Figure 30. COKE YIELD (AFTER $1,000^{\circ} \mathrm{C}$ ) AND g FACTOR (AFTER $2,800^{\circ} \mathrm{C}$ ) OF CARBON SAMPLES DERIVED FROM MIXTURES OF CINNAMYLIDENEINDENE AND PYROMELLITIC DIANHYDRIDE AS FUNCTIONS OF THE PYROMELLITIC DIANHYDRIDE CONTENT.

Table 12

WEIGHT AND VOLUME YIELDS OF TRUXENE AT $1,000^{\circ} \mathrm{C}$

\begin{tabular}{llcc}
\hline $\begin{array}{c}\text { Sample } \\
\text { Number }\end{array}$ & Air Cure & $\begin{array}{c}\text { Coke Yield } \\
\text { After } \\
1,000^{\circ} \mathrm{C} \\
(\%)\end{array}$ & $\begin{array}{c}\text { Volume Yield } \\
\text { After } \\
1,000^{\circ} \mathrm{C} \\
(\%)\end{array}$ \\
\hline 10-05-68G1 & No & 56 & - \\
$11-16-69 A$ & No & 54 & - \\
G-67-1A & Yes(1) & 70 & 49 \\
G-67-1B & Yes(1) & 82 & 57 \\
G-67-1C & Yes(1) & 69 & 48 \\
G-67-1D & Yes(1) & 86 & 60 \\
I-G-78 & Yes(1) & 69 & - \\
I-G-83 & Yes(1) & 75 & - \\
$7-54-67$ & Yes(1) & 82 & 61 \\
L1-123-9-G10 & Yes(2) & $94(4)$ & - \\
L1-123-9-G4 & Yes(3) & $92(4)$ & - \\
\hline
\end{tabular}

(1) Air cure consisted of heating in a programmed cycle to a maximum of $250^{\circ} \mathrm{C}$.

(2) Air cure consisted of heating at $200^{\circ} \mathrm{C}$ for 120 hours.

(3) Air cure consisted of heating at $275^{\circ} \mathrm{C}$ for 65 hours.

(4) Calculations did not include weight loss associated with a prior heat treatment. 


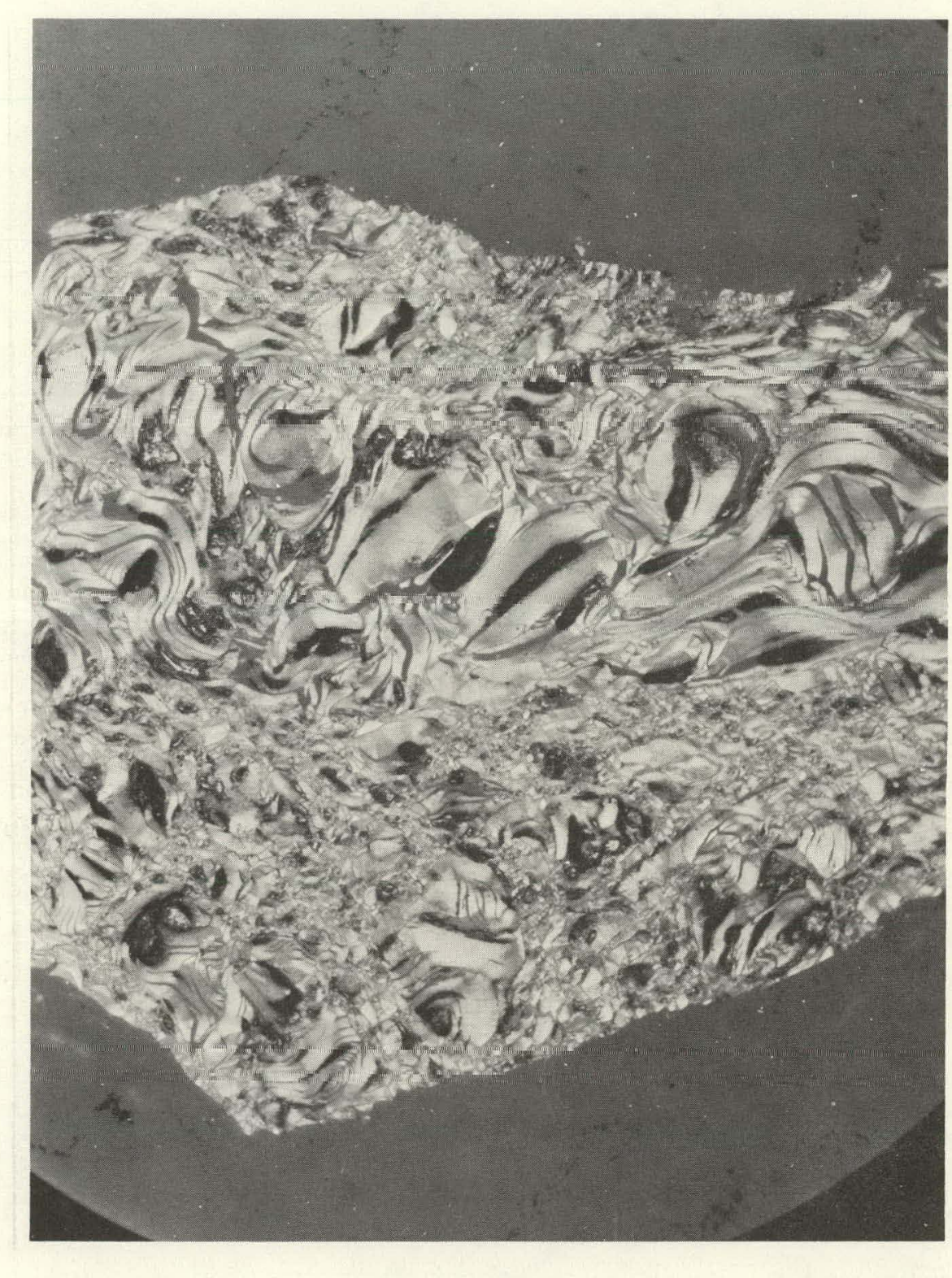

(a) $0 \%$ PMDA

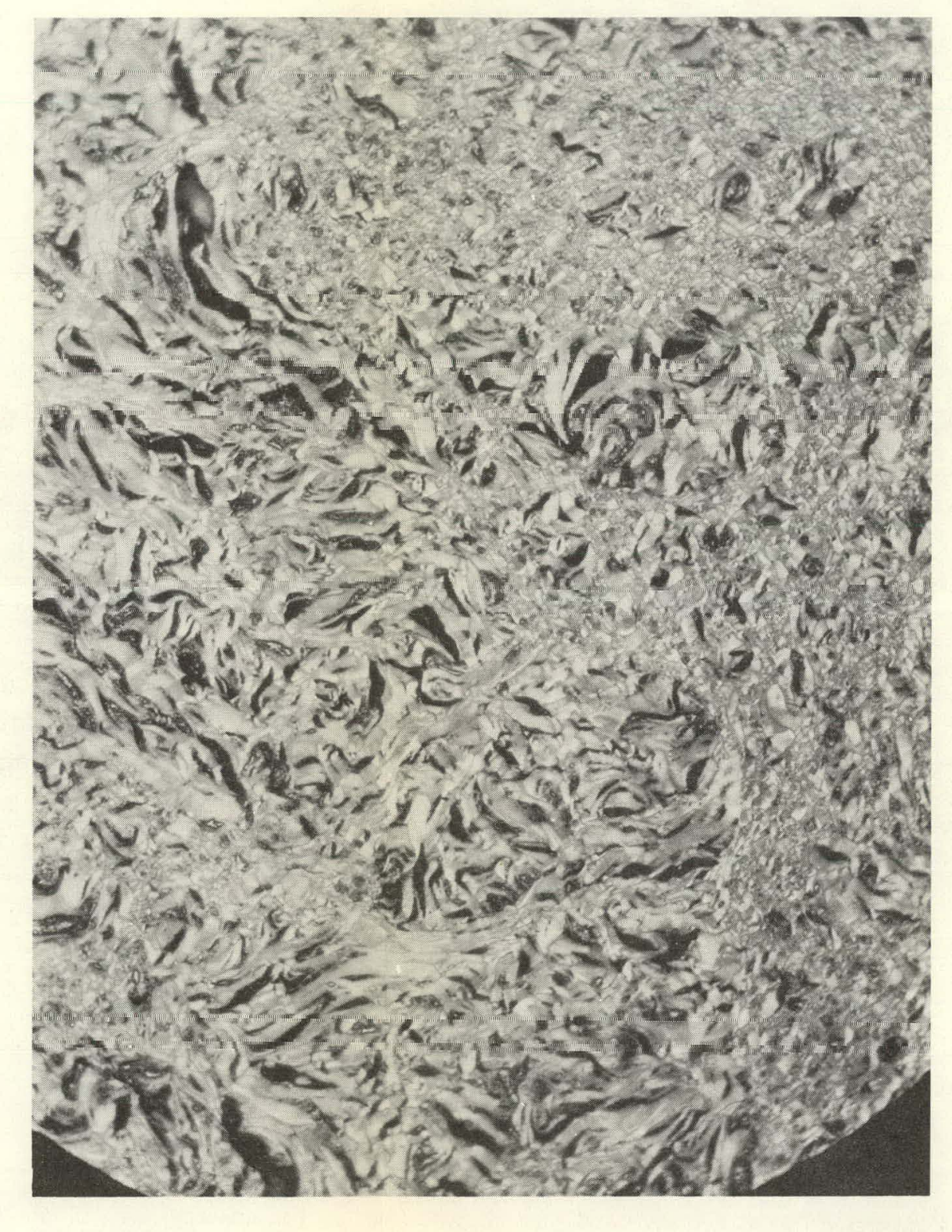

(b) $10 \%$ PMDA

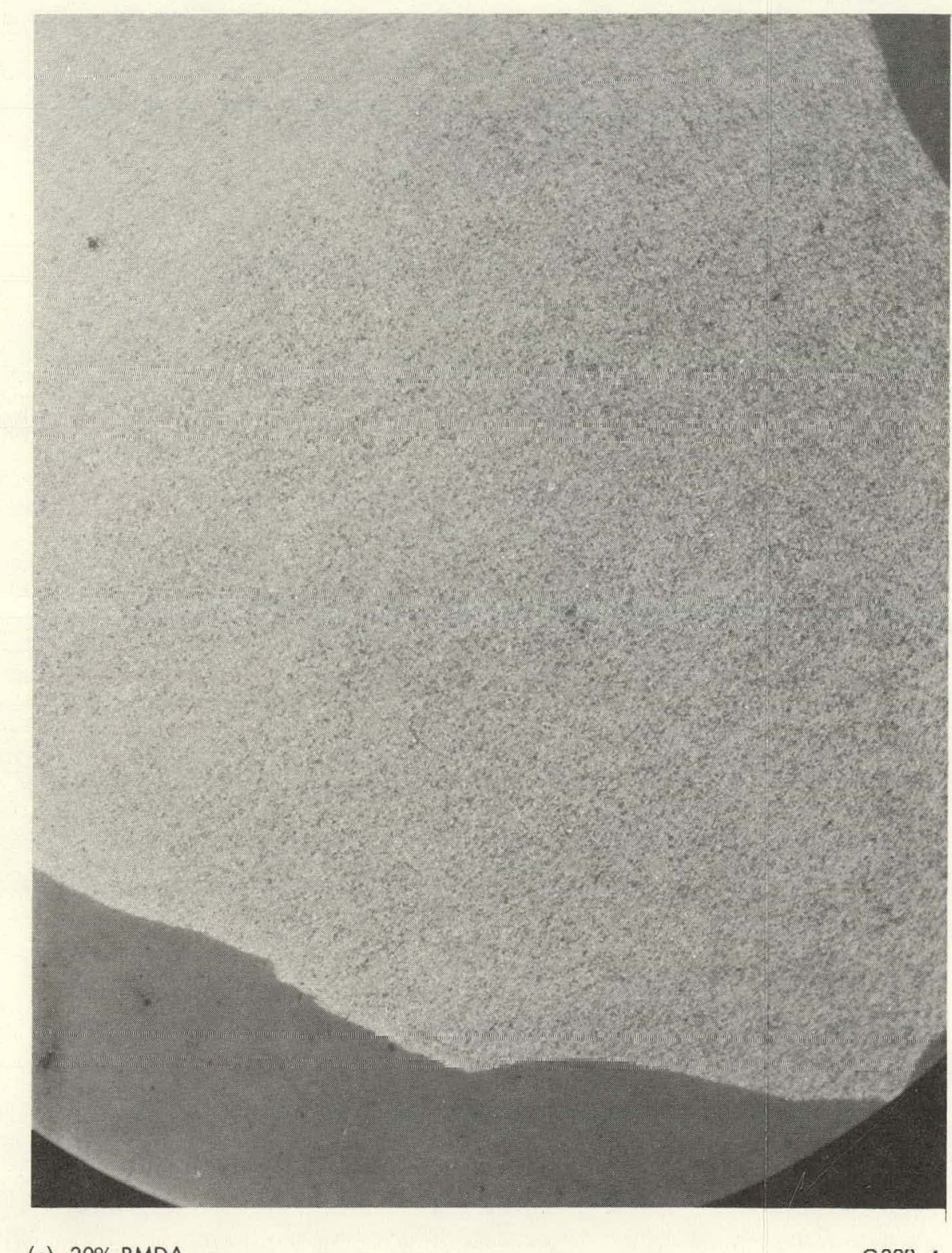

G332-4

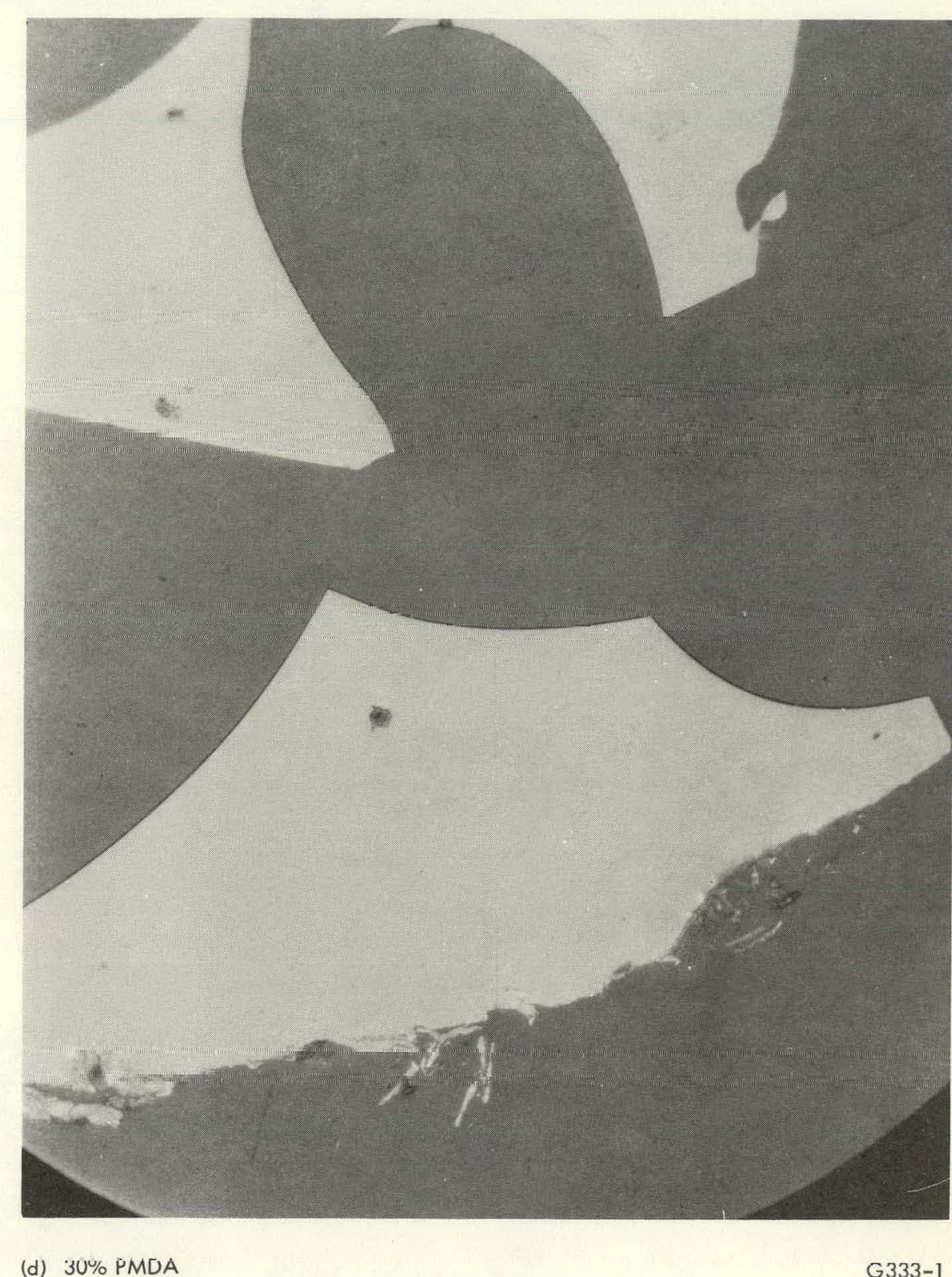

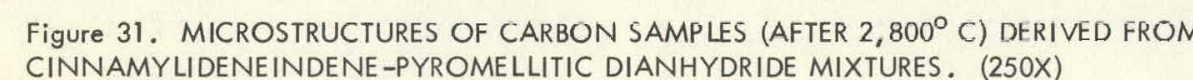

1 


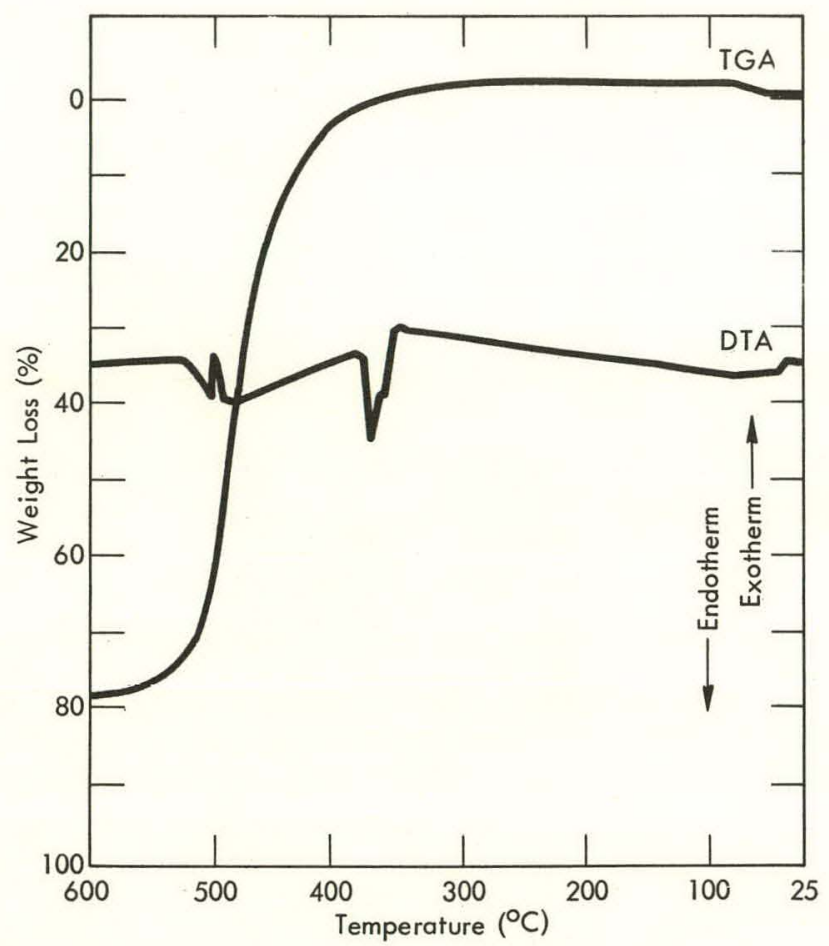

Figure 32. THERMOGRAM OF TRUXENE. (Heating Rate, $\left.6^{\circ} \mathrm{C} / \mathrm{min}\right)$

As indicated in Table 13, the density of TX-derived carbon decreased at firing temperatures above $1,000^{\circ} \mathrm{C}$, attaining values of $1.4-1.5 \mathrm{gms} / \mathrm{ml}$ after $2,800^{\circ} \mathrm{C}$. This decrease in density with firing temperature denotes the formation of closed porosity. As shown in Figure 33, an expected decrease in surface area accompanies the decrease in density.

Table 13

PROPERTIES OF CARBON DERIVED FROM TRUXENE AS A FUNCTION OF THE FIRING TEMPERATURE

\begin{tabular}{|c|c|c|c|c|c|}
\hline $\begin{array}{l}\text { Temperature } \\
\text { to Which } \\
\text { Carbon, Was } \\
\text { Fired (1) } \\
\text { (० C) }\end{array}$ & $\frac{\text { Densi }}{\text { Helium }}$ & $\frac{y \mathrm{~ms} / \mathrm{ml} \text { ) }}{\text { Mercury }}$ & $\begin{array}{l}\text { Surface } \\
\text { Area } \\
\left.\text { ( } \mathrm{m}^{2} / \mathrm{gm}\right)\end{array}$ & $\begin{array}{c}\text { Porosity } \\
\text { (\%) }\end{array}$ & $\begin{array}{l}\text { Pores Less } \\
\text { Than } 10 \mu \\
\text { (\%) }\end{array}$ \\
\hline 1,000 & 1.86 & 1.46 & 78.67 & 45.28 & 7.35 \\
\hline 1,600 & 1.45 & 1.43 & 2.53 & 5.06 & 45.28 \\
\hline 2,000 & 1.39 & 1.40 & 0.62 & 2.95 & 54.79 \\
\hline 2,400 & 1.35 & 1.40 & 0.28 & - & - \\
\hline 2,800 & 1.47 & 1.52 & 0.24 & 6.84 & 50.6 \\
\hline
\end{tabular}

(1) Carbonization cycle included a room temperature to $250^{\circ} \mathrm{C}$ cure in air previous to carbonization. 


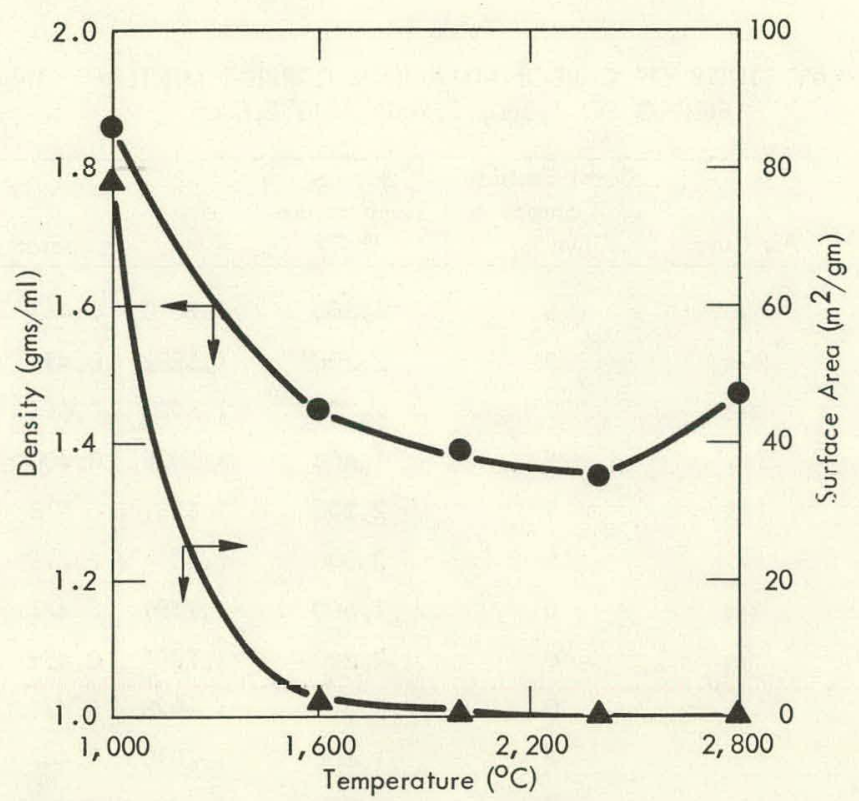

Figure 33. DENSITY AND SURFACE AREA OF TRUXENE-DERIVED CARBON SAMPLES AS FUNCTIONS OF THE FIRING TEMPERATURE.

Data included in Table 14 (Samples C, K, S, G, 0, and W) show the degree of graphiticity of TX-derived carbons. Air-cure conditions did not appear to alter these properties. A typical microstructure of TX-derived carbon is shown in Figure 34.

Effect of Metals on the Graphitizability of Truxene-Derived Carbon - In general, carbon that exists in the amorphous form can be made to crystallize by processes which produce molten carbon that is subsequently allowed to solidify. This transition can be effected at temperatures below the standard melting temperature of carbon by the addition of metals and/or metal carbides to carbon such that eutectic mixtures are formed. Efforts to promote graphitization of TX-derived carbon involved the addition of titanium carbide powder $(260-1,400 \mathrm{~A})$ to $600^{\circ} \mathrm{C}$ carbon samples ( -20 to $\left.60 \mathrm{mesh}\right)$, and firing these samples to $1,600,2,200$, and $2,800^{\circ} \mathrm{C}$ with hold times of one hour. Data obtained for the mixtures are included in Table 14 which allows a comparison to be made with samples containing no titanium carbide. The effect of titanium carbide on the graphiticity of TX-derived carbon is quite apparent in Figure 35, which indicates a significant increase in the graphiticity of samples containing titanium carbide. As also indicated in Figure 35, the use of an air cure prior to carbonization of the precursor had little or no effect on the graphitization process. 
Table 14

$X$-RAY STUDY OF CARBON-TITANIUM CARBIDE MIXTURES ON FIRING TO $1,600,2,200$, AND $2,800^{\circ} \mathrm{C}$

\begin{tabular}{ccccccc}
\hline Sample $(1)$ & Air Cure & $\begin{array}{c}\text { Metal Carbide } \\
\text { Content } \\
(\text { wt } \%)\end{array}$ & $\begin{array}{c}\text { Firing } \\
\text { Temperature } \\
\left({ }^{\circ} \mathrm{C}\right)\end{array}$ & $\begin{array}{c}\mathrm{d} 004 \\
(\mathrm{~A})\end{array}$ & $\mathrm{g}$ factor & $\begin{array}{c}\mathrm{L} \\
(\mathrm{A})\end{array}$ \\
\hline A & Yes & 5 & 1,600 & 1.7010 & 0.447 & - \\
I & Yes & 5 & 2,200 & 1.6992 & 0.494 & - \\
Q & Yes & 5 & 2,800 & 1.6906 & 0.694 & 89 \\
E & No & 5 & 1,600 & 1.7028 & 0.400 & - \\
M & No & 5 & 2,200 & 1.6981 & 0.518 & - \\
U & No & 5 & 2,800 & 1.6894 & 0.718 & 92 \\
C & Yes & 0 & 1,600 & 1.7001 & 0.471 & - \\
K & Yes & 0 & 2,200 & 1.7007 & 0.459 & - \\
S & Yes & 0 & 2,800 & 1.6998 & 0.471 & - \\
G & No & 0 & 1,600 & 1.7010 & 0.447 & - \\
O & No & 0 & 2,200 & 1.6992 & 0.494 & - \\
W & No & 0 & 2,800 & 1.7039 & 0.376 & - \\
\hline
\end{tabular}

(1) Carbon was derived from truxene by heating to $600^{\circ} \mathrm{C}$ either with or without a prior air cure. Air cure consisted of programmed heating cycle, reaching a maximum of $250^{\circ} \mathrm{C}$ after $\sim 50$ hours. Carbon was ground, sieved, and $-20+60$ mesh powder was blended with metal carbide powders $(260-1,400 \mathrm{~A})$ prior to firing.

Microstructures (after 2,800 C) of these carbon-titanium carbide mixtures show a very faint grain structure and an occasional area of high crystallinity. Typical microstructures are shown in Figure 36. The presence of titanium carbide in single carbon particles is apparent in Figure 36. Since the carbon and carbide materials were blended as powders, diffusion must have occurred and probably results in frontal zones as points where amorphous carbon becomes plastic or molten on a microscopic scale, and deposits a crystalline carbon as the frontal zone advances. If so, graphitization by this procedure would be rate dependent, and the rate would increase with increasing temperature. The eutectic temperature of titanium carbide-carbon systems is $2,776 \pm 12^{\circ} \mathrm{C} .(12)$

Analysis of one of the titanium carbide-carbon mixtures by microprobe methods indicated high concentrations of titanium in areas having grain textures, as depicted in Figure 36. Both electron and titanium $X$-ray images are shown in Figure 37 for a single area of a titanium carbide-carbon sample (Sample $U$ in Table 14) which was previously fired to $2,800^{\circ} \mathrm{C}$. Areas having grain textures contained 4-6 percent titanium while other areas contained negligible quantities of titanium. 


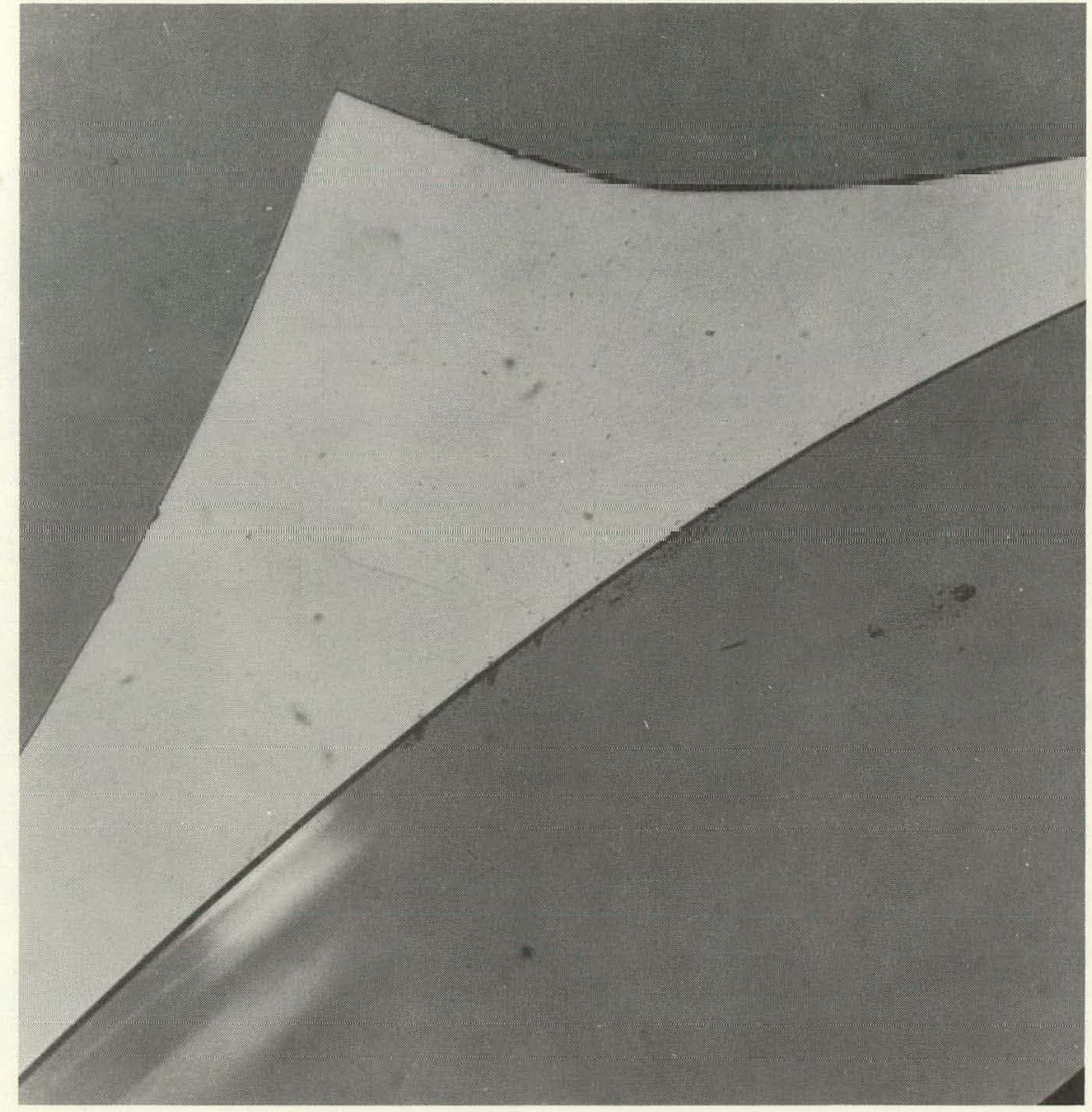

F990-1

Figure 34. MICROSTRUCTURE OF A CARBON SAMPLE (AFTER 2,800 C) DERIVED FROM TRUXENE. (250X)

Truxene-Pyromellitic Dianhydride Mixtures - The effect of PMDA on the coke yield and carbon properties of TX-derived carbon was evaluated, and the resulting data are given in Table 15. As is obvious from Table 15, PMDA, which consists of 44 percent oxygen, gives a low char yield on pyrolysis. However, TX-PMDA mixtures have coke yields that are much higher than would be anticipated from weight-averaging calculations. This fact is apparent in Figure 38, which indicates that compositions with 0 to 55 percent PMDA have coke yields higher than TX alone. Maximum values correspond to PMDA contents of $20-25$ percent. These data indicate significant interaction between TX and PMDA at these conditions. Properties of carbon derived from mixtures of TX and PMDA were quite similar to those derived from the individual precursors. This fact is indicated by the X-ray data in Table 15. Microstructures of these carbons shows no crystalline phases, and looked much the same as those obtained from $T X$. 


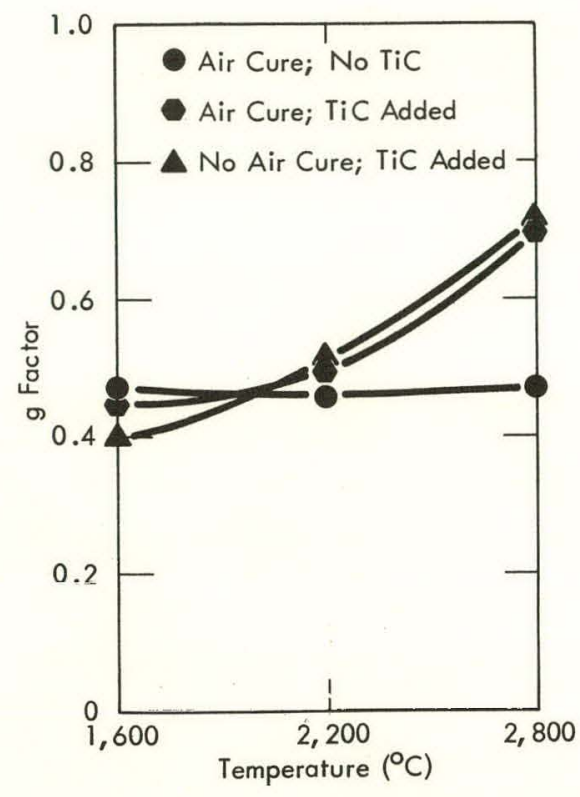

Figure 35. GRAPHITICITY OF CARBONFIVE PERCENT TITANIUM CARBIDE MIXTURES AS A FUNCTION OF THE FIRING TEMPERATURE. (Truxene-Derived Carbon, Fired to $600^{\circ} \mathrm{C}$ Both With and Without an Air Cure, was Blended with Titanium Carbide Prior to a High-Temperature Firing)

Table 15

PROPERTIES OF CARBONS DERIVED FROM TRUXENEPYROMELLITIC DIANHYDRIDE MIXTURES

\begin{tabular}{|c|c|c|c|c|c|}
\hline \multirow[b]{2}{*}{$\begin{array}{c}\text { Sample } \\
\text { Number }\end{array}$} & \multirow{2}{*}{$\begin{array}{c}\text { PMDA } \\
\text { Content } \\
(\%)\end{array}$} & \multirow{2}{*}{$\begin{array}{c}\text { Carbon Yield } \\
\text { After } \\
1,000^{\circ} \mathrm{C} \\
\left({ }^{\circ} \mathrm{C}\right)\end{array}$} & \multicolumn{3}{|c|}{ Properties Atter 2, , $800^{\circ} \mathrm{C}$} \\
\hline & & & $\begin{array}{l}\text { doo4 } \\
\text { (A) }\end{array}$ & $\mathrm{g}$ factor & $\begin{array}{l}L_{c} \\
(A)\end{array}$ \\
\hline$\| A$ & 0 & 54 & 1.7039 & 0.365 & 65 \\
\hline IIB & 5 & 54 & 1.7143 & 0.129 & 49 \\
\hline IIC & 10 & 59 & 1.7098 & 0.235 & 60 \\
\hline IID & 15 & 59 & 1.7104 & 0.224 & 66 \\
\hline IIE & 20 & 60 & 1.7095 & 0.247 & 54 \\
\hline IIF & 25 & 75 & 1.7086 & 0.271 & 66 \\
\hline||$B \mid$ & 35 & 70 & - & - & - \\
\hline IIB2 & 50 & 60 & - & - & - \\
\hline IIB3 & 75 & 38 & - & - & - \\
\hline IIB4 & 100 & 1 & - & - & - \\
\hline
\end{tabular}




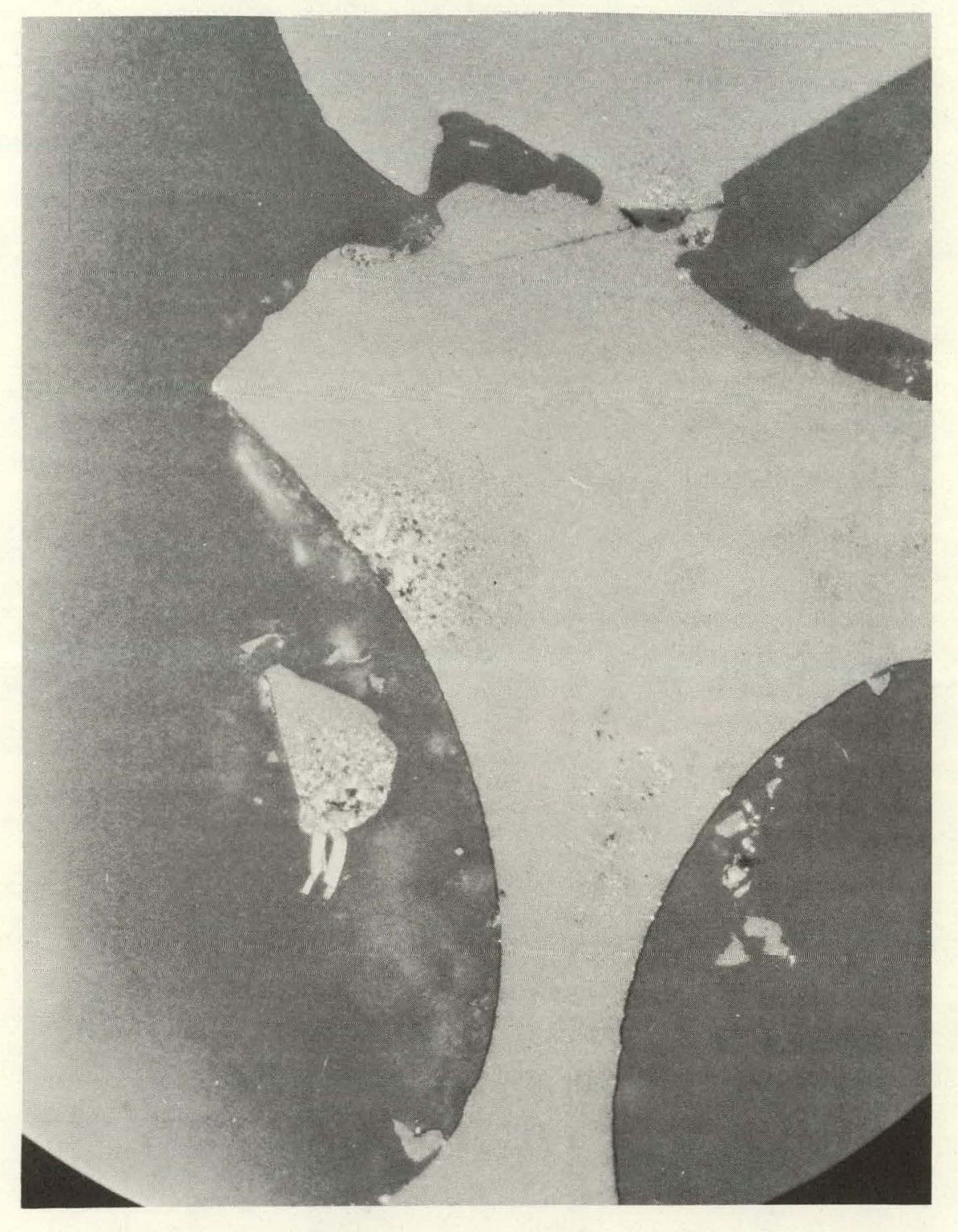

(a) Truxene Carbonized without a Prior Air Cure (Sample U)

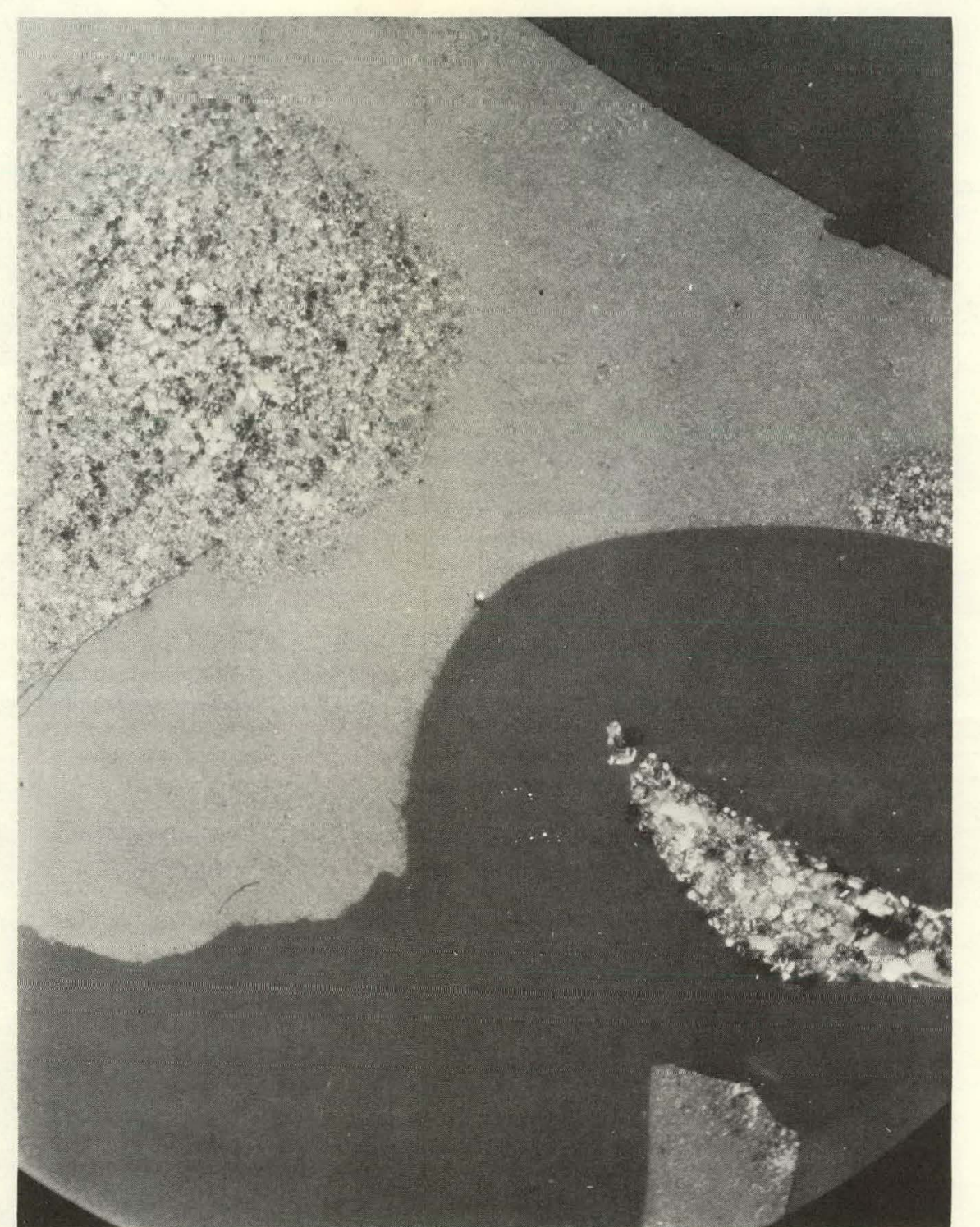

(b) Truxene Carbonized with a Prior Air Cure (Sample Q) Figure 3 . MICROSTRUCTURES OF CARBON SAMPLES (AFTER 2,800 $\mathrm{C}$ ) DERIVED BY BLENDING
$600^{\circ} \mathrm{C}$-TRUXENE COKE WITH FIVE PERCENT TITANIUM CARBIDE. (250X)

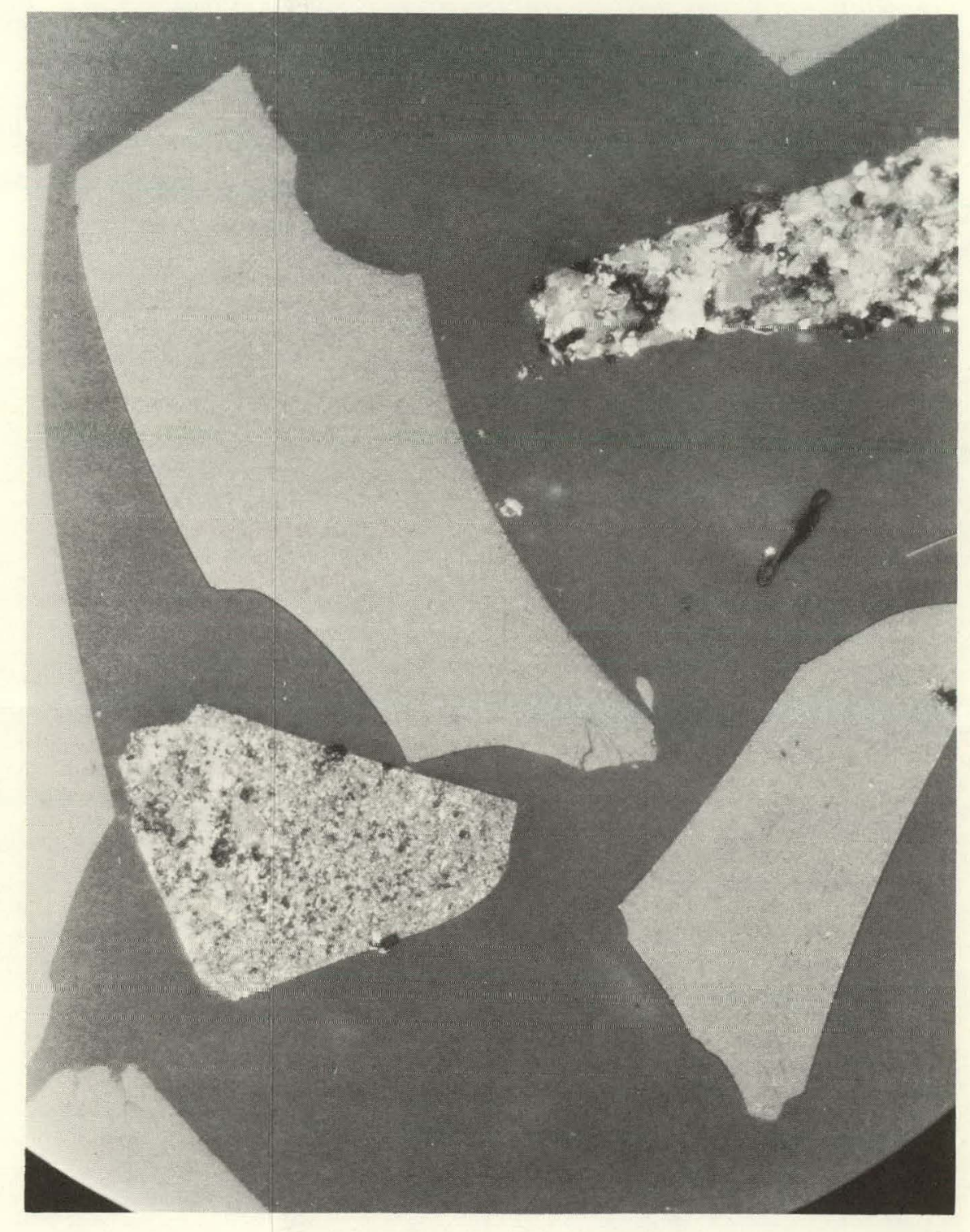

(c) Truxene C.arbonized with a Prior Air Cure (Sample QA)

F848-1A 


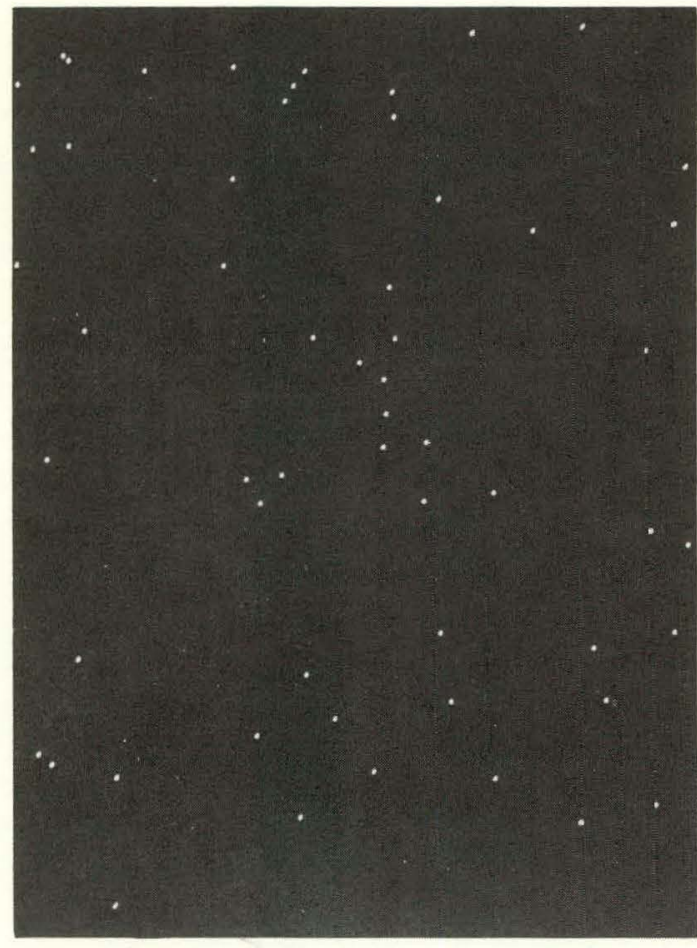

(a) Titanium X-Ray Background Image of Area A

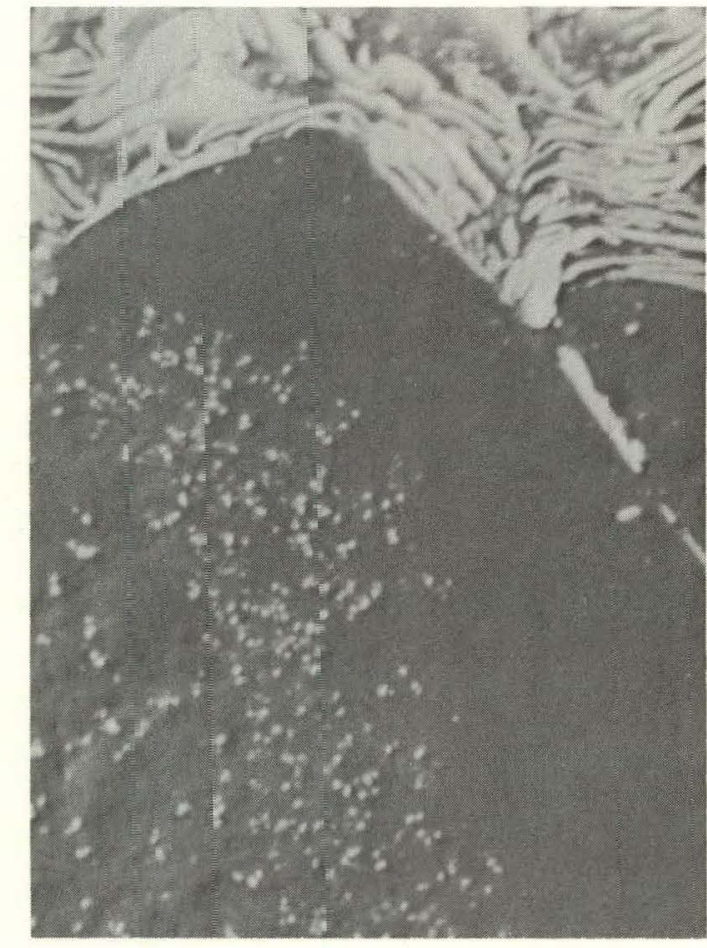

(b) Backscattered Elect'on Image of Area A

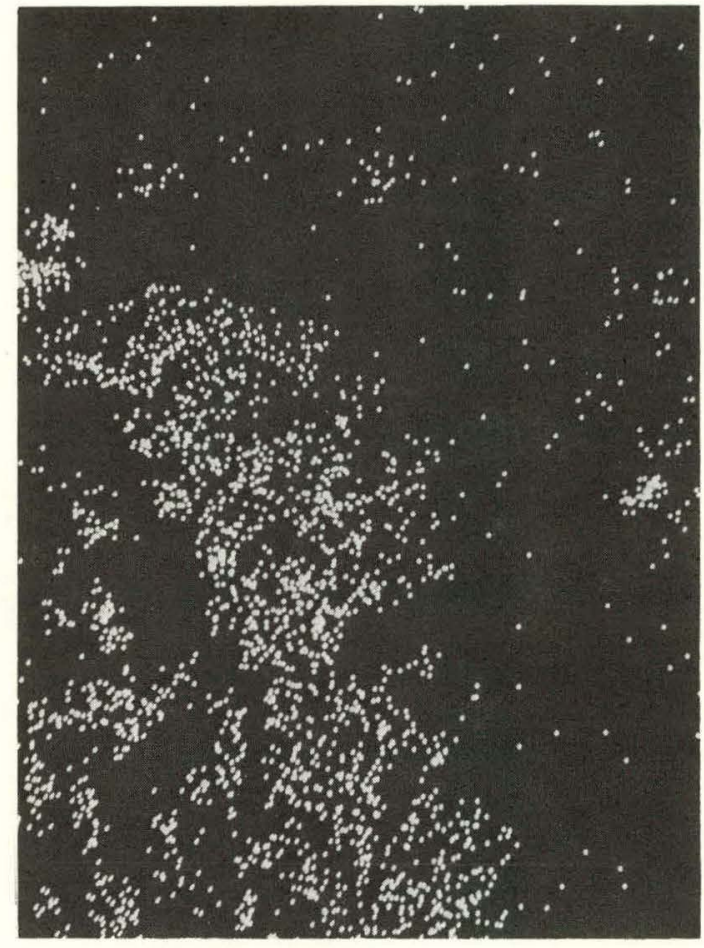

ic) Titanium X-Ray Image of Area A

Figure 37. MICROPROBE ANALYSIS OF A TITANIUM CARBIDE-CARBON MIXTURE SHOWING THE DISTRIBUTION OF TITANIUM IN THE CARBON. (500X) 


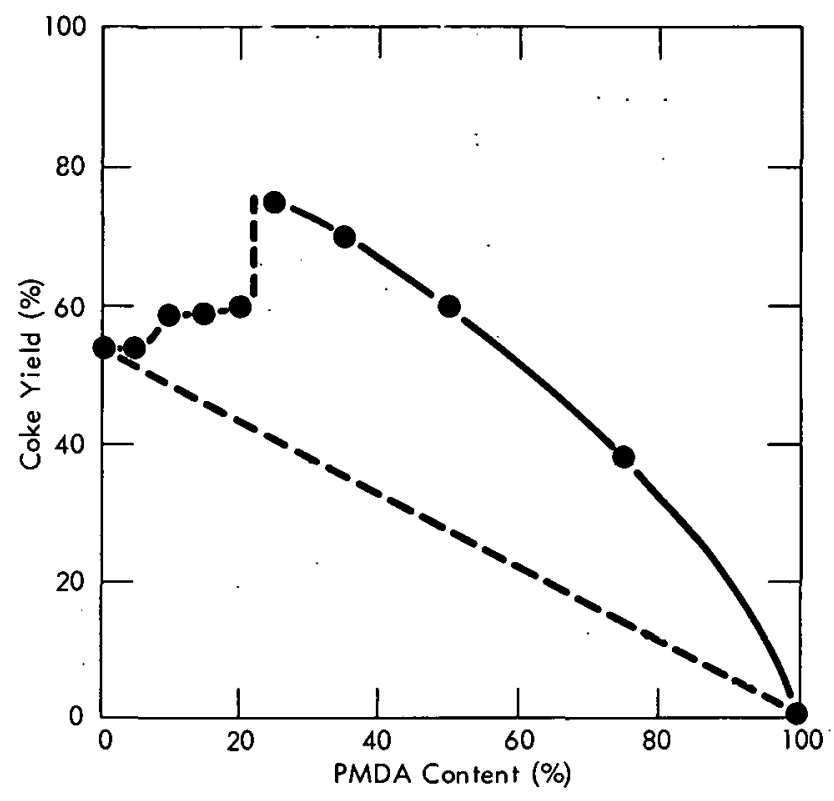

Figure 38. COKE YIELD (AFTER $1,000^{\circ} \mathrm{C}$ ) OF TRUXENE-PYROMELLITIC DIANHYDRIDE MIXTURES AS A FUNCTION OF THE PYROMELLITIC DIANHYDRIDE CONTENT.

Isotruxene

Isotruxene (ITX) is isomeric with truxene (TX) as is apparent by comparing their respective molecular structures (see TX structure on Page 53). The structure for isotruxene is:

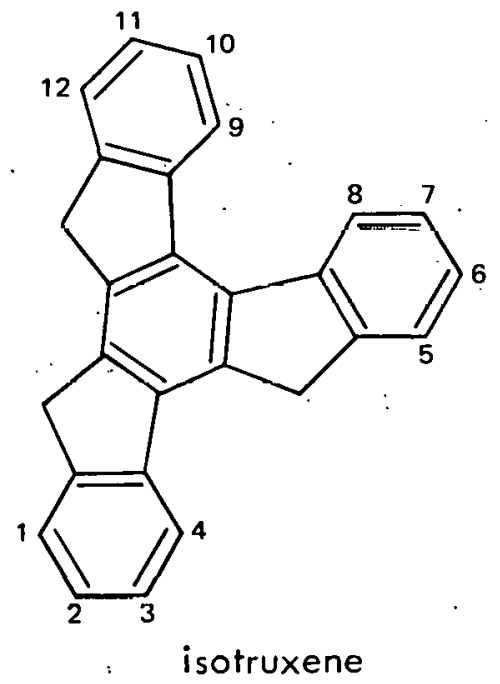

Isotruxene can be produced jointly with TX by autoclave treatment of indene or it can be produced free of TX from reactions of indene and 1,4-naphthoquinone in the presence of tertiary amines. $(8)$ The latter procedure results 
in ITX products which contain a residual polymeric phase that typically represents $10-30$ weight percent of the sample, and is essentially a tetramer of indene. A molecular distribution that is typical of ITX products that were prepared by the latter procedure is shown in Figure 39.

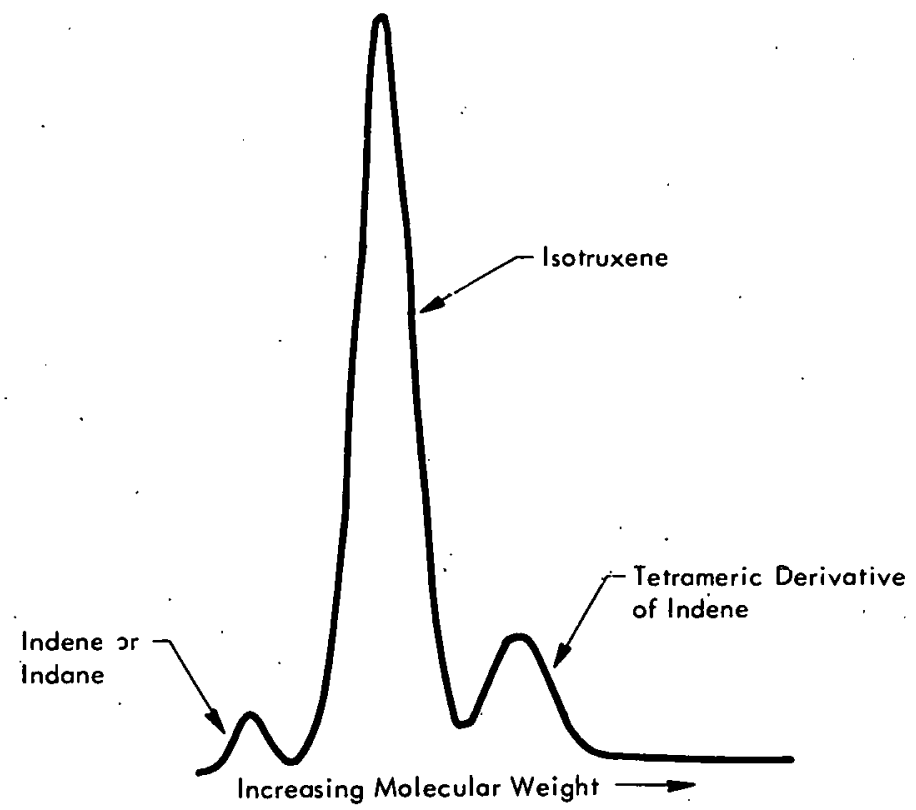

Figure 39. GEL PERMEATION CHRQMATOGRAPHY SCAN SHOWING THE MOLLECULAR DISTRIBUTION OF ISOTRUXENE AS PREPARED BY THE REACTION OF INDENE IN THE PRESENCE OF 1, 4-NAPHTHOQUINONE.

Thermal behavior of the tetrameric material suggested a molecular structure which fragments into monomeric and trimeric species. Samples of the tetrameric material were isolated and were heated at temperatures above $300^{\circ} \mathrm{C}$ to produce a nonvolatile product that was largely isotruxene, and monomeric fragments which consisted principally of indene. The change in molecular distribution on heat treatment of the tetrameric product is indicated in Figure 40. In general, IT.X products used in this evaluation were derived from 1,4-naphthoquinone-indene reactions, and contained $10-20$ percent of this tetrameric polymer.

As indicated by the thermogram in Figure 41, ITX melts at approximately $220^{\circ} \mathrm{C}$ and pyrolytic polymerization occurs at approximately $550^{\circ} \mathrm{C}$, It is interesting to compare the differential thermal analysis behavior of the isomeric truxenes (see Figure 32), and to compare other differences in the physical and chemical properties that result from the slight but significant difference in molecular structure. ITX is less symmetrical in structure than 


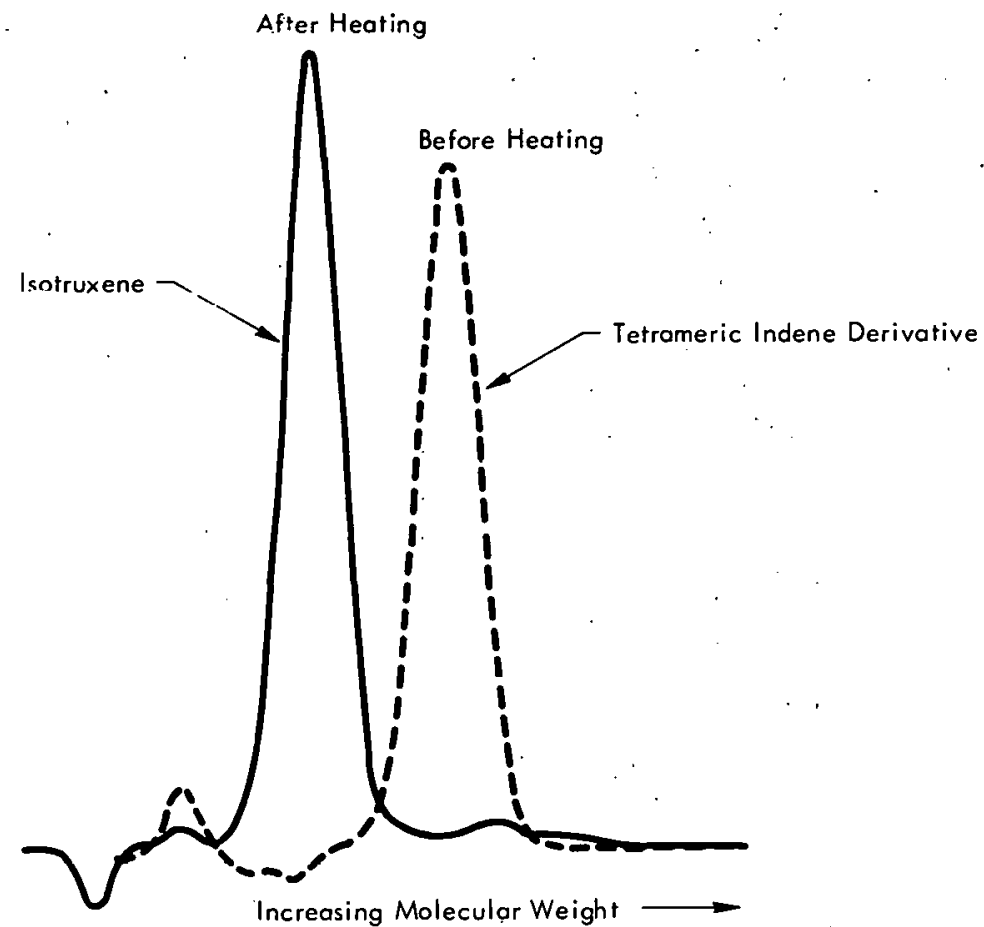

Figure 40. GEL PERMEATION CHROMATOGRAPHY SCANS SHOWING THE MOLECULAR DISTRIBUTIONS BEFORE AND AFTER HEAT TREATMENT (2 HOURS, $350^{\circ} \mathrm{C}$ ) OF. THE TETRAMERIC INDENE DERIVATIVE.

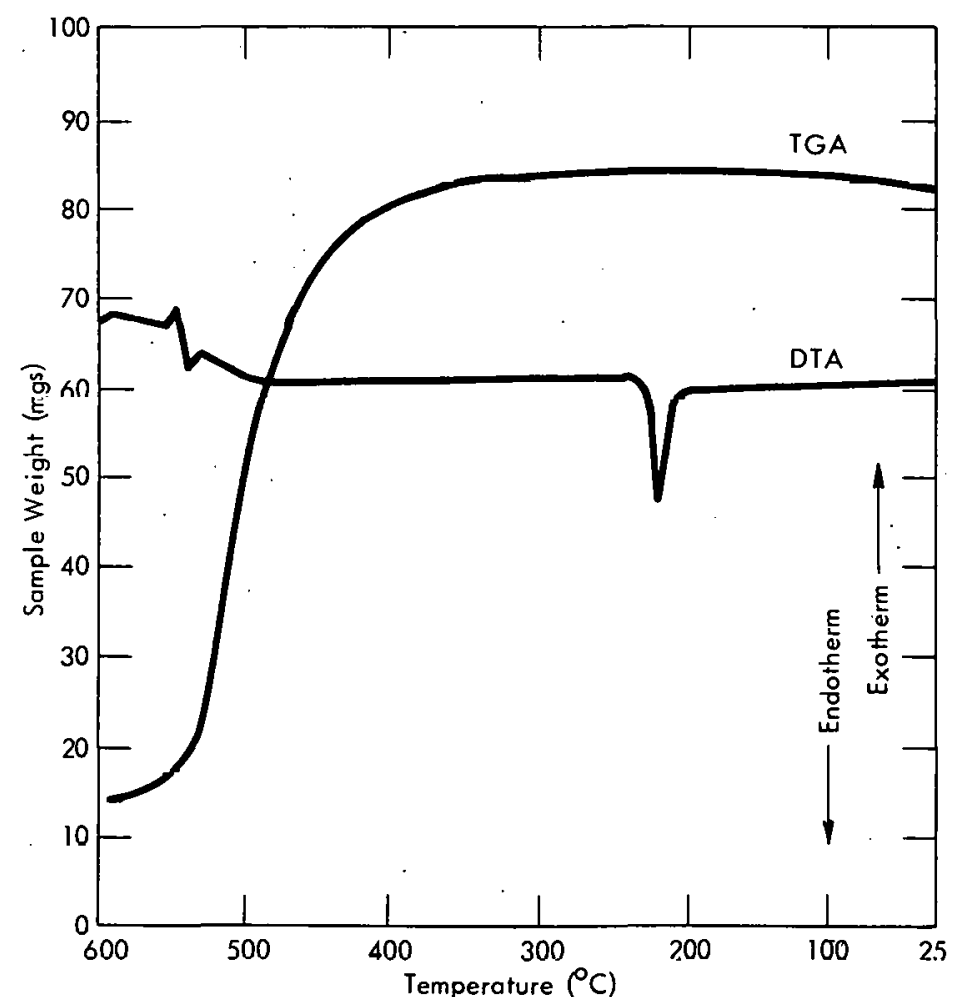

Figure 41. THERMOGRAM OF ISOTRUXENE. (Heating Rate, $6^{\circ} \mathrm{c} / \mathrm{min}$ ) 
TX and is, therefore, less crystalline, has a lower melting point, and is more soluble. The molecular arrangement of the ITX structure also results in bond strain; and ITX is, thus, more reactive than TX. Finally, ITX-derived carbon is more graphitic than that derived from TX. Thus, the physical properties and thermal behavior of ITX prior to pyrolysis are more conducive to molecular orientation.

The viscosity of molten ITX is shown as a function of temperature in Figure 42. At temperatures above $300^{\circ} \mathrm{C}$, values became essentially constant.

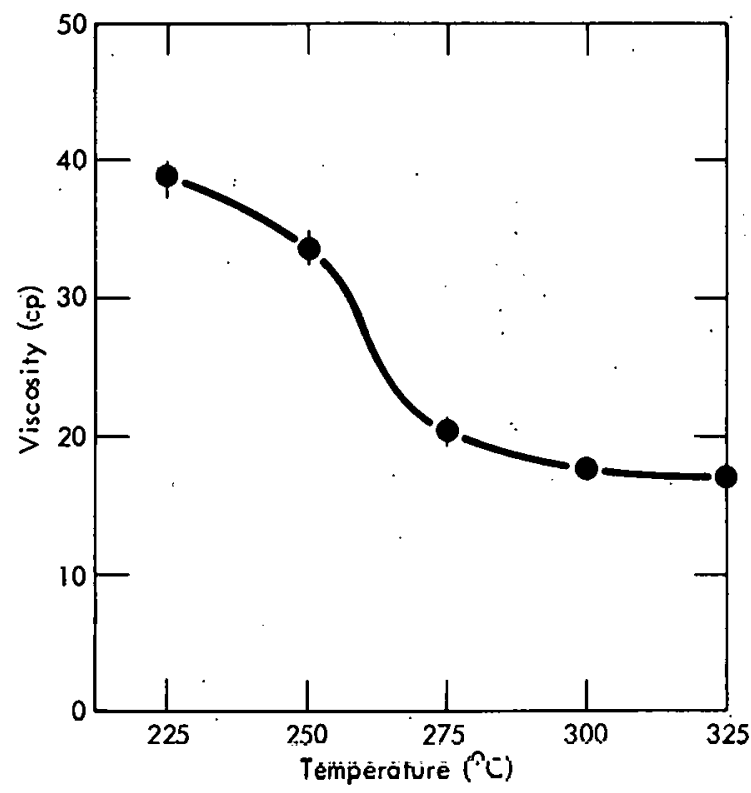

Figure 42. VISCOSITY OF ISOTRUXENE (CONTAINING $66 \%$ ISOTRUXENE) AS A FUNCTION OF THE TEMPERATURE.

Coke yields and carbon properties derived from ITX were significantly influenced by polymerization or cure conditions, as discussed in detail in the subsections that follow. The density of $1,000^{\circ} \mathrm{C}$ carbon was $1.8-1.9 \mathrm{gms} / \mathrm{ml}$ while that of the precursor was approximately $1.25 \mathrm{gms} / \mathrm{ml}$.

These data will permit correlations of the coke-yield and volume-yield values by using the data of Figures 1 and 2 .

Properties of Carbon Derived from Isotruxene (ITX) without a Prior Air Cure - As previously stated, the properties of carbon derived from ITX are influenced by the air-cure conditions prior to carbonization. Initially, carbons derived from uncured samples will be considered. Table 16 lists the data 
Table 16

PROPERTIES OF CARBON DERIVED FROM ISOTRUXENE WHICH RECEIVED NO AIR CURE PRIOR TO CARBONIZATION

\begin{tabular}{|c|c|c|c|c|c|c|}
\hline \multirow[b]{2}{*}{$\begin{array}{c}\text { Sample } \\
\text { Number(1) }\end{array}$} & \multirow[b]{2}{*}{$\begin{array}{c}\text { Isotruxene } \\
\text { Content (2) } \\
(\%)\end{array}$} & \multirow{2}{*}{$\begin{array}{c}\text { Coke Yield } \\
\text { After } \\
1,000^{\circ} \mathrm{C} \\
(\%)\end{array}$} & \multicolumn{4}{|c|}{ Properties After $2,800^{\circ} \mathrm{C}$} \\
\hline & & & $\begin{array}{c}\text { Helium } \\
\text { Density } \\
\text { (gms/cc) }\end{array}$ & $\begin{array}{c}\mathrm{d} 004 \\
(\mathrm{~A})\end{array}$ & $\mathrm{g}$ factor & $\begin{array}{l}\mathrm{L}_{\mathrm{c}} \\
(\mathrm{A})\end{array}$ \\
\hline $10-89-69-A 2$ & 66 & 25 & - & 1.6986 & 0.506 & 99 \\
\hline $10-92-69-A 2$ & 69 & 26 & - & 1.7004 & 0.459 & 112 \\
\hline $10-82-69-A 2$ & 79 & 39 & - & 1.7010 & 0.447 & 120 \\
\hline $10-05-68-G 2$ & 79 & 44 & 2.08 & 1.7025 & 0.412 & 101 \\
\hline $10-84-69-A 2$ & 83 & 45 & - & 1.7025 & 0.412 & 97 \\
\hline $10-05-68-G 4(3)$ & 91 & 45 & 2.11 & 1.7002 & 0.471 & 155 \\
\hline $10-89-69-C(4)$ & 91 & 45 & - & 1.6998 & 0.471 & 155 \\
\hline
\end{tabular}

(1) Isotruxene was prepared by the reaction (under retlux) of indene in the presence of 1,4-naphthoquinone and tertiary amine catalysts.

(2) Isotruxene content in products was determined by GPC analyses.

(3) This is a portion of Sample 10-05-68-G2 after recrystallization from hot xylene.

(4) This sample had been heated at $300^{\circ} \mathrm{C}$ in an inert atmosphere for 168 hours.

that were obtained for various samples of ITX products which contained the secondary polymeric phase referred to previously. In general, coke yields increased with the increasing ITX content.

Properties of carbons derived from uncured samples of ITX correspond to those of a fine-grain, isotropic carbon with a low order of graphiticity. Though not pronounced, the data in Table 16 indicated that graphiticity and crystallite size were influenced somewhat by the presence of the polymeric phase in the precursor. A typical microstructure of ITX-derived carbon is presented in Figure 43.

Properties of Carbon Derived from Isotruxene with an Air Cure - Isotruxene samples that received an air cure prior to carbonization produced a more graphitic carbon than the carbon derived from uncured samples. One method of air curing consisted of heating 20 - 50-gram samples contained in graphite crucibles to $250^{\circ} \mathrm{C}$ during a 50 -hour rate-controlled cycle. This procedure also resulted in significant increases in the coke yield. These facts are apparent when the data in Table 17 is compared with that for uncured samples in Table 16. Table 17 lists data for ITX samples containing various quantities of the tetrameric polymer that is coproduced with ITX. In general, interlayer spacings (d004) of air-cured samples are in the range of 1.68 to $1.685 \mathrm{~A}$ while those from uncured samples are in the range of 1.699 to $1.703 \mathrm{~A}$. A similar comparison of crystallite-size $\left(L_{c}\right)$ values indicate that uncured 


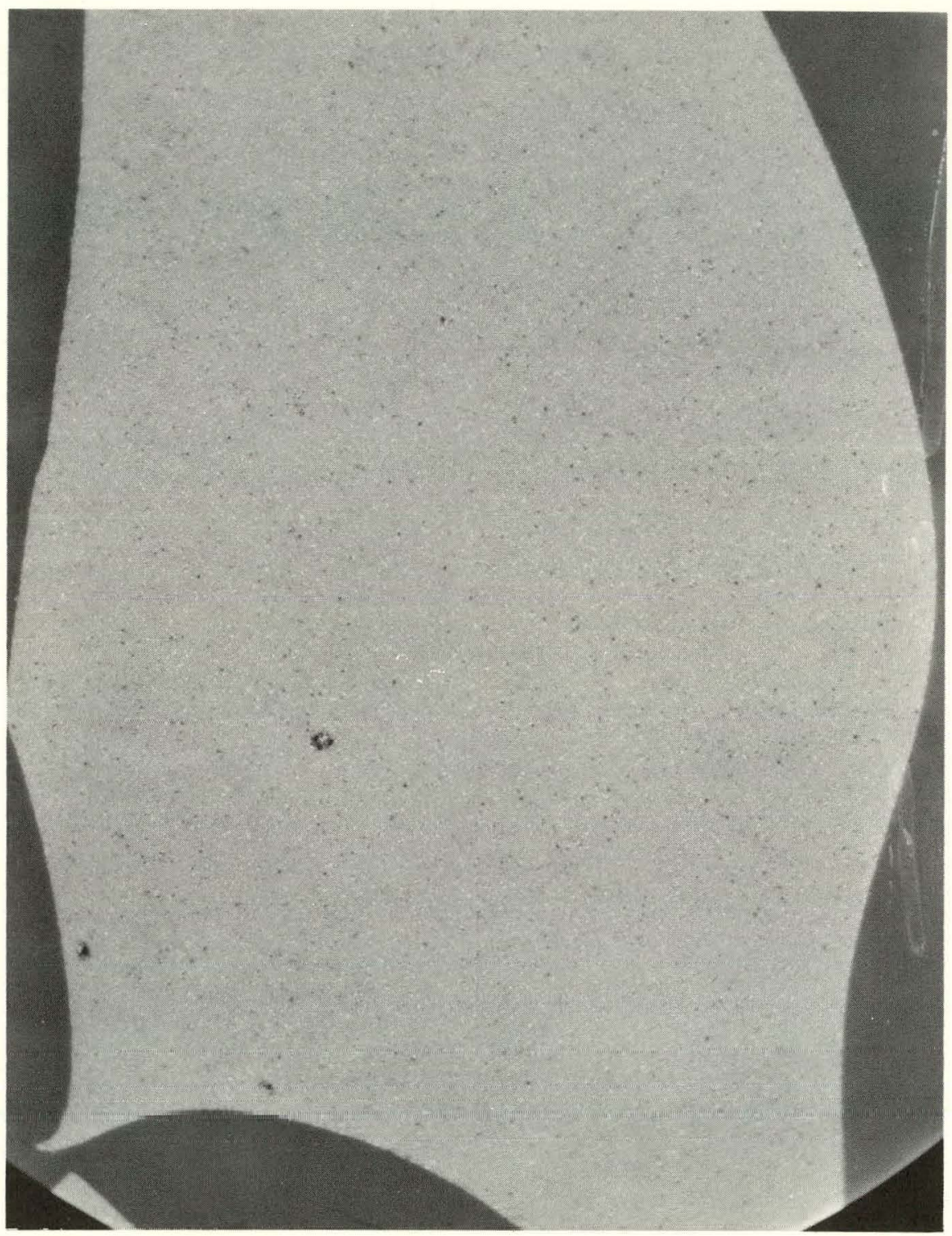

F681-2

Figure 43. MICROSTRUCTURE OF A CARBON SAMPLE (AFTER 2,800 C) DERIVED FROM THE ISOTRUXENE PRODUCT (83\% ISOTRUXENE). (250X)

samples have values in the range of 100 to $150 \mathrm{~A}$, while those for cured samples are from 200 to 250 A. For samples containing 80 percent ITX or greater, coke-yield values were observed to increase from approximately 45 percent to approximately 70 percent as a result of the prior air cure. A direct comparison of coke yields and carbon properties of air-cured and uncured samples can be seen in Figure 44. As is apparent in Figure 44, coke yields, g factors, and the crystallite sizes of air-cured samples were essentially constant for samples containing less than 70 percent ITX, but were observed to increase 
at higher ITX concentrations. Microstructures of carbon from the air-cured ITX samples, shown in Figure 45, exhibited coarse-grain textures that lacked uniformity. Little or no microstructural differences were observed which would be accredited to the composition of the precursor.

Table 17

PROPERTIES OF CARBON DERIVED FROM ISOTRUXENE WHICH WAS HEAT TREATED IN AIR PRIOR TO CARBONIZATION

\begin{tabular}{|c|c|c|c|c|c|}
\hline \multirow[b]{2}{*}{$\begin{array}{c}\text { Sample } \\
\text { Number (1) }\end{array}$} & \multirow{2}{*}{$\begin{array}{c}\text { Isotruxene } \\
\text { Content (2) } \\
(\%)\end{array}$} & \multirow{2}{*}{$\begin{array}{c}\text { Coke Yield } \\
\text { After } \\
1,000^{\circ} \mathrm{C} \\
(\%)\end{array}$} & \multicolumn{3}{|c|}{ Properties After $2,800^{\circ} \mathrm{C}$} \\
\hline & & & $\begin{array}{l}\mathrm{d} 004 \\
(\mathrm{~A})\end{array}$ & $\mathrm{g}$ factor & $\begin{array}{l}L_{c} \\
(A)\end{array}$ \\
\hline L2-01-9-13H & 20 & 63 & 1.6834 & 0.859 & 237 \\
\hline $\mathrm{L} 2-01-9-8 \mathrm{H}$ & 50 & 64 & 1.6836 & 0.859 & 222 \\
\hline L2-01-9-1H & 65 & 63 & 1.6842 & U.847 & 220 \\
\hline $10-92-69-A 1$ & 69 & 63 & 1.6845 & 0.835 & 206 \\
\hline $10-05-68-G 3$ & 79 & 66 & 1.6814 & 0.906 & 253 \\
\hline $\mathrm{L} 2-01-9-12 \mathrm{H}$ & 80 & 70 & 1.6836 & 0.859 & 241 \\
\hline $10-84-69-A 1$ & 83 & 71 & 1.6831 & 0.871 & 247 \\
\hline
\end{tabular}

(1) Samples were heated in air during a 50 -hour rate-controlled cycle which attained a maximum of $250^{\circ} \mathrm{C}$.

(2) Estimated from GPC scans.

Additional studies were conducted to determine the correlation between carbon properties and heat-treatment time at constant temperature. Samples (50 grams) were heated in air at $300^{\circ} \mathrm{C}$ for periods up to 120 hours. These data are reported in Table 18. Molecular distributions of the 24-hour sample and the soluble portion of the 72-hour sample are seen in Figure 46 . After 72 hours, two monomeric species are indicated. The second material probably is an oxo form resulting from the oxidation of ITX at the methylene sites to give carbonyl groups, as has been accomplished with other oxidizing agents. (8)

The increase in coke yields with heat-cure time is indicated in Figure 47 along with the carbon densities after 1,000 and $2,800^{\circ} \mathrm{C}$. As indicated, density data for both temperatures were essentially independent of the precursor heat-cure time. The effect of an air cure on the graphitic properties of ITXderived carbon is again dramatized by the data in Figure 47, showing pronounced increases in the $\mathrm{g}$ factor and crystallite size as a result of relatively short initial heat-treatment times. Changes in these properties after the initial 24 hours were minimal. A microstructure typical of carbon from these samples is presented in Figure 48.

Properties of Isotruxene-Derived Carbon as a Function of the Firing Temperature between 1,000 and $2,800^{\circ} \mathrm{C}$ - Samples of ITX were air cured to $250^{\circ} \mathrm{C}$, 


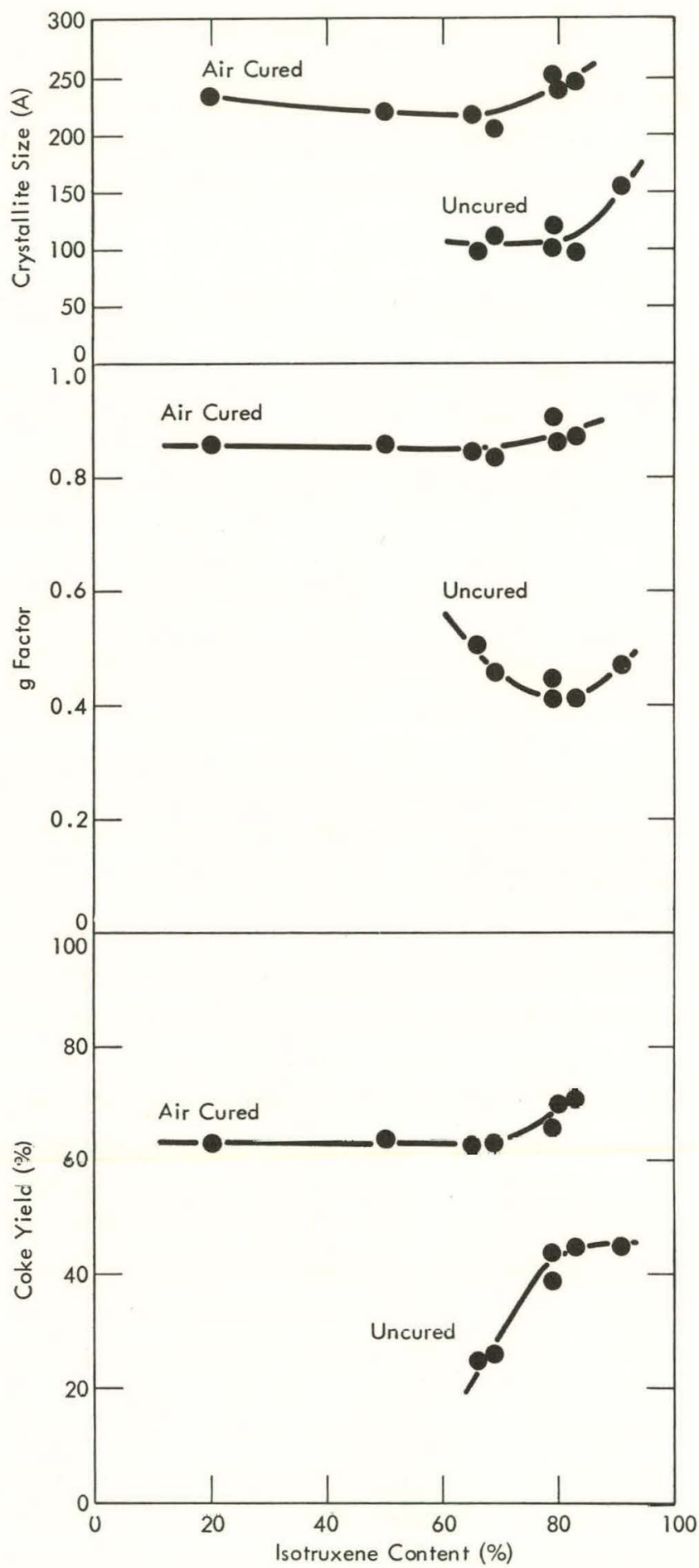

Figure 44. CRYSTALLITE SIZE (AFTER $2,800^{\circ} \mathrm{C}$ ), g FACTOR, AND COKE YIELD (AFTER $1,000^{\circ} \mathrm{C}$ ) OF CARBON SAMPLES DERIVED FROM ISOTRUXENE PRODUCTS AS FUNCTIONS OF THE ISOTRUXENE CONTENT.

carbonized to $1,000^{\circ} \mathrm{C}$, and were subsequently fired to $1,600,2,000,2,400$, and $2,800^{\circ}$ C. Density and X-ray data for two sets of carbon samples are 

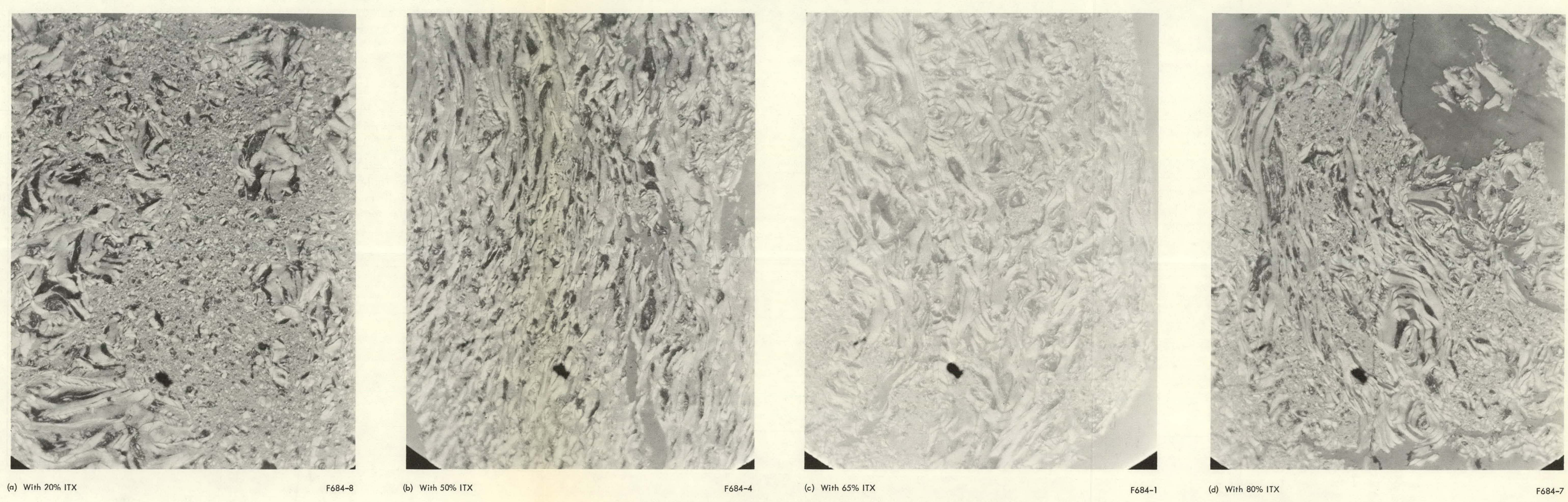

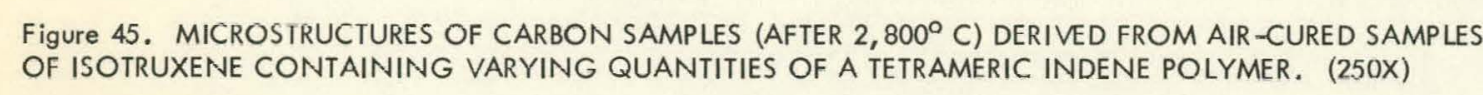


Table 18

PROPERTIES OF CARBON DERIVED FROM ISOTRUXENE AS A FUNCTION OF THE CURE TIME IN AIR

\begin{tabular}{|c|c|c|c|c|c|c|c|}
\hline \multirow[b]{2}{*}{$\begin{array}{c}\text { Sample } \\
\text { Number (1) }\end{array}$} & \multirow[b]{2}{*}{$\begin{array}{c}\text { Air Cure } \\
\text { Time (2) } \\
\text { (hours) }\end{array}$} & \multicolumn{2}{|c|}{ Properties After $1,000^{\circ} \mathrm{C}$} & \multicolumn{4}{|c|}{ Properties After $2,800^{\circ} \mathrm{C}$} \\
\hline & & $\begin{array}{c}\text { Coke Yield } \\
(\%)\end{array}$ & $\begin{array}{c}\text { Helium } \\
\text { Density } \\
\text { (gms/cc) }\end{array}$ & $\begin{array}{l}\text { Helium } \\
\text { Density } \\
\text { (gms/cc) }\end{array}$ & $\begin{array}{l}d_{0} 04 \\
(A)\end{array}$ & $\mathrm{g}$ factor & $\begin{array}{l}\mathrm{L}_{\mathrm{C}} \\
(\mathrm{A}) \\
\end{array}$ \\
\hline G4 & 0 & 44 & 1.80 & 2.11 & 1.7002 & 0.471 & 155 \\
\hline G5 & 24 & 68 & 1.88 & 2.09 & 1.6825 & 0.882 & 213 \\
\hline G6 & 48 & 80 & 1.89 & 2.10 & 1.6828 & 0.871 & 228 \\
\hline G7 & 72 & 83 & 1.87 & 2.04 & 1.6828 & 0.871 & 205 \\
\hline G8 & 96 & 82 & 1.87 & 2.12 & - & - & 215 \\
\hline G10 & 120 & 83 & 1.84 & 2.15 & 1.6831 & 0.871 & 218 \\
\hline
\end{tabular}

(1) Isotruxene was recrystallized prior to use; GPC analysis indicated an isotruxene content of 91 percent.

(2) Fifty-gram samples of isotruxene, contained in graphite crucibles ( $3.5^{\prime \prime} \mathrm{D} \times 3^{\prime \prime} \mathrm{H}$ ), were heated at $300^{\circ} \mathrm{C}$ in an air atmosphere.

listed in Table 19 as a function of temperature. Collectively, these samples indicated little change in density after $1,600^{\circ} \mathrm{C}$. The correlation of density and firing temperature is emphasized in Figure 49. As shown in Table 19,

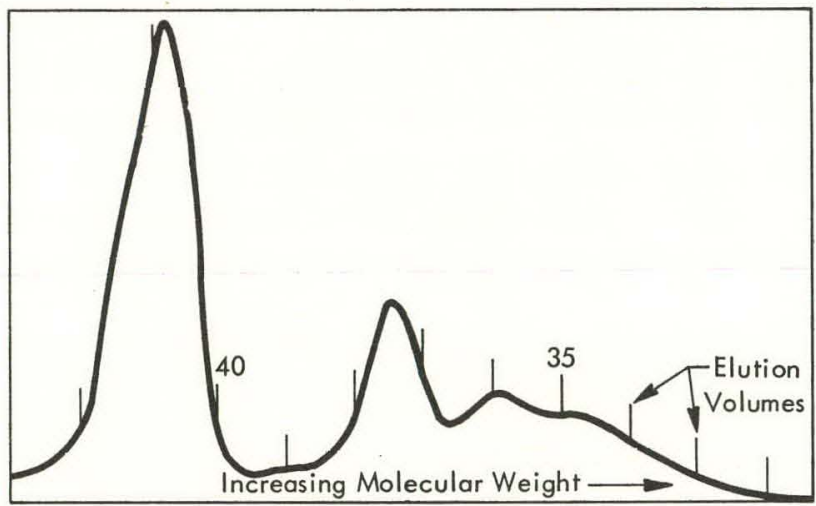

(a) After 24 Hours

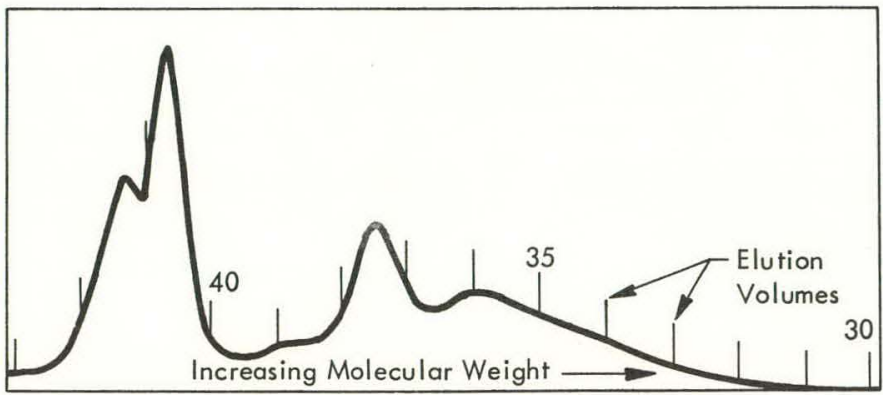

(b) After 72 Hours (only $49 \%$ of sample soluble in THF)

Figure 46. GEL PERMEATION CHROMATOGRAPHY SCANS SHOWING THE MOLECULAR DISTRIBUTION OF ISOTRUXENE AS A FUNCTION OF THE CURE TIME IN AIR. 
X-ray data obtained for the $2,800^{\circ} \mathrm{C}$ carbons from Series N1 and N2 1 were quite comparable. The correlation of graphitic properties with firing temperature is seen in Figure 50 for Series N21. These data indicate significant increases in the $g$ factor and $L_{c}$ values on increasing the firing temperature from 2,000 to $2,400^{\circ} \mathrm{C}$. Less pronounced changes were observed with additional increases in temperature.

Figure 51 gives an indication of the transition that occurs in X-ray diffraction response with an increasing firing temperature. Likewise, Figure 52 allows

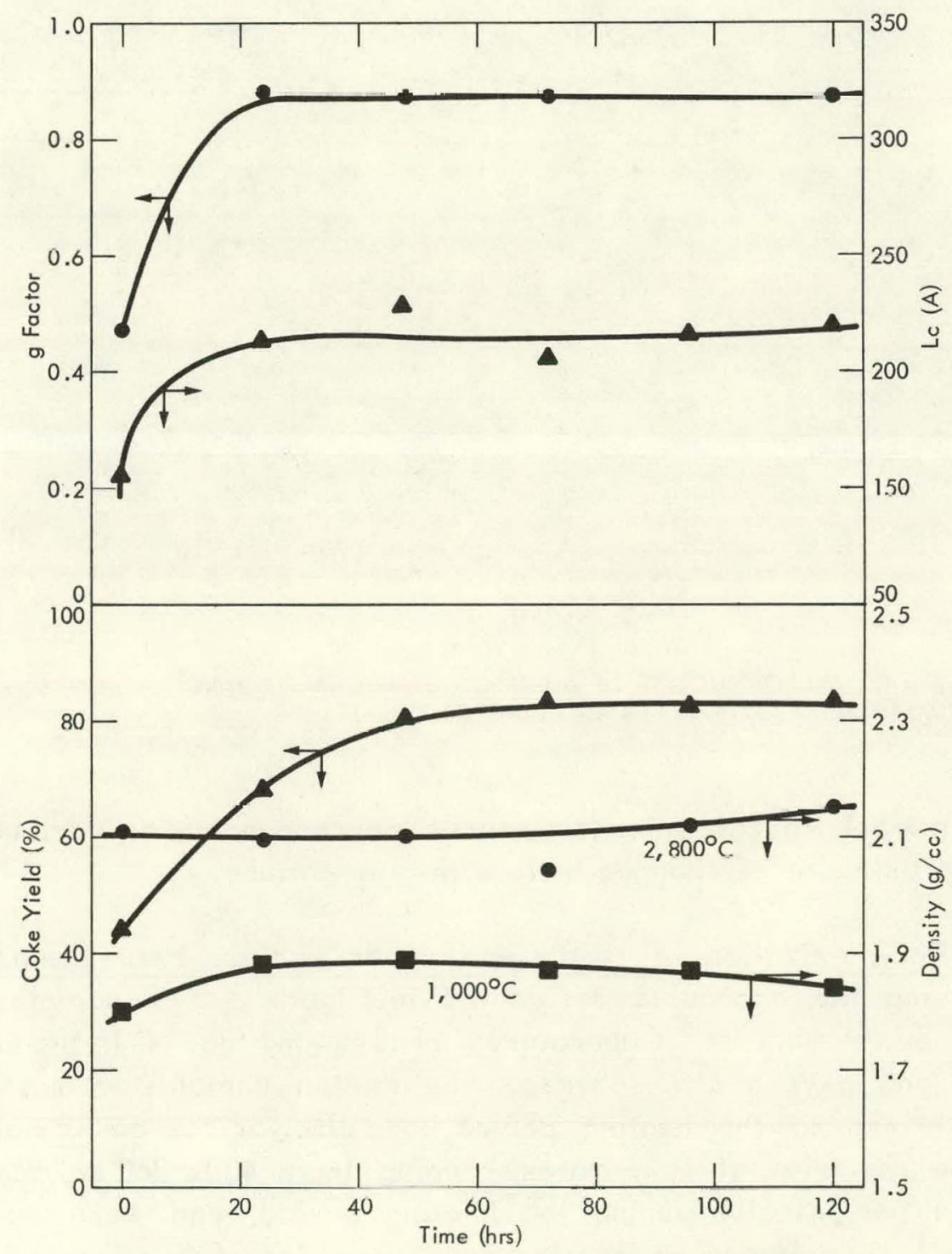

Figure 47. COKE YIELD (AFTER $1,000^{\circ} \mathrm{C}$ ), DENSITY, g FACTOR, AND CRYSTALLITE SIZE (AFTER $2,800^{\circ} \mathrm{C}$ ) OF ISOTRUXENE AS FUNCTIONS OF THE AIR-CURE TIME IN GRAPHITE CRUCIBLES AT $300^{\circ} \mathrm{C}$. 


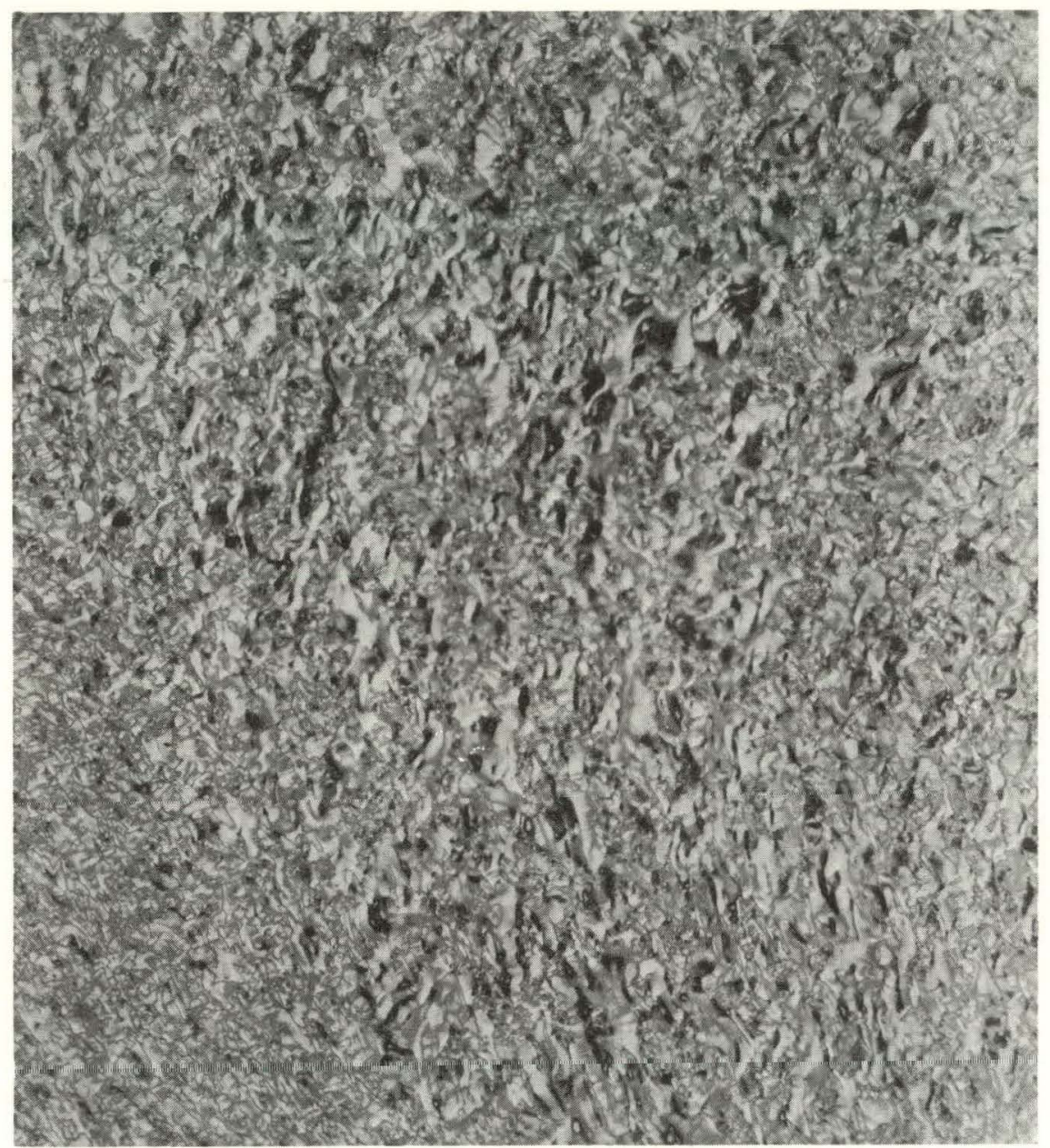

E715-6

Figure 48. MICROSTRUCTURE OF A CARBON SAMPLE (AFTER 2,800 $\mathrm{C}$ ) FROM ISOTRUXENE AFTER 120 HOURS IN AIR AT $300^{\circ} \mathrm{C}$. (250X)

a comparison of carbon microstructures corresponding to varisus temperatures. Microstructures changed little with temperature.

Oxidative Polymerization of Isotruxene under Various Heat-Treatment Conditions - Using the apparatus designated in Figure 3, ITX samples were polymerized by heating at temperatures of 245 and $300^{\circ} \mathrm{C}$ in the presence of both inert and oxygen atmospheres. The molten samples were stirred continuously throughout the heating period, and the various gases were bubbled through the material at flow rates ranging from 40 to $360 \mathrm{cc} / \mathrm{min}$. Samples were taken periodically during the heating period, and were characterized with respect to polymer properties and properties of derived carbon. Properties of materials that resulted from the various heat-treatment conditions are discussed in the topics that follow. 
Table 19

PROPERTIES OF CARBON DERIVED FROM AIR-CURED ISOTRUXENE AS A FUNCTION OF TEMPERATURE OVER THE RANGE FROM 1,000 TO $2,800^{\circ} \mathrm{C}$

\begin{tabular}{|c|c|c|c|c|c|}
\hline $\begin{array}{l}\text { Sample } \\
\text { Number }\end{array}$ & $\begin{array}{c}\text { Firing } \\
\text { Temperature } \\
\left({ }^{\circ} \mathrm{C}\right)\end{array}$ & $\begin{array}{l}\text { Helium } \\
\text { Density } \\
(\text { gms } / \mathrm{ml})\end{array}$ & $\begin{array}{c}\mathrm{d} 004 \\
(\mathrm{~A})\end{array}$ & $\mathrm{g}$ factor & $\begin{array}{l}L_{c} \\
(A) \\
\end{array}$ \\
\hline \multirow[t]{5}{*}{$\mathrm{NI}(1)$} & 1,000 & 1.84 & \multicolumn{3}{|c|}{ (coke yield $78.8 \%$ ) } \\
\hline & 1,600 & 2.13 & & & \\
\hline & 2,000 & 2.14 & & & \\
\hline & 2,400 & 2.16 & & & \\
\hline & 2,800 & 2.18 & 1.6817 & 0.906 & 315 \\
\hline \multirow[t]{5}{*}{$N_{21}{ }^{(2)}$} & 1,000 & 1.79 & \multicolumn{3}{|c|}{ (coke yield $09.5 \%$ ) } \\
\hline & 1,600 & 2.13 & & & \\
\hline & 2,000 & 2.14 & 1.7080 & 0.282 & 126 \\
\hline & 2,400 & 2.19 & 1.6845 & 0.835 & 255 \\
\hline & 2,800 & 2.17 & 1.6820 & 0.894 & 314 \\
\hline
\end{tabular}

(1) Samples were heat treated in air at $300^{\circ} \mathrm{C}$ for 16 hours prior to heat treatment (in air) in programmed cycle to $250^{\circ} \mathrm{C}$, and subsequent carbonization to $1,000^{\circ} \mathrm{C}$ in an inert atmosphere.

(2) Sample heated in air in programmed cycle to $250^{\circ} \mathrm{C}$ prior to carbonization.

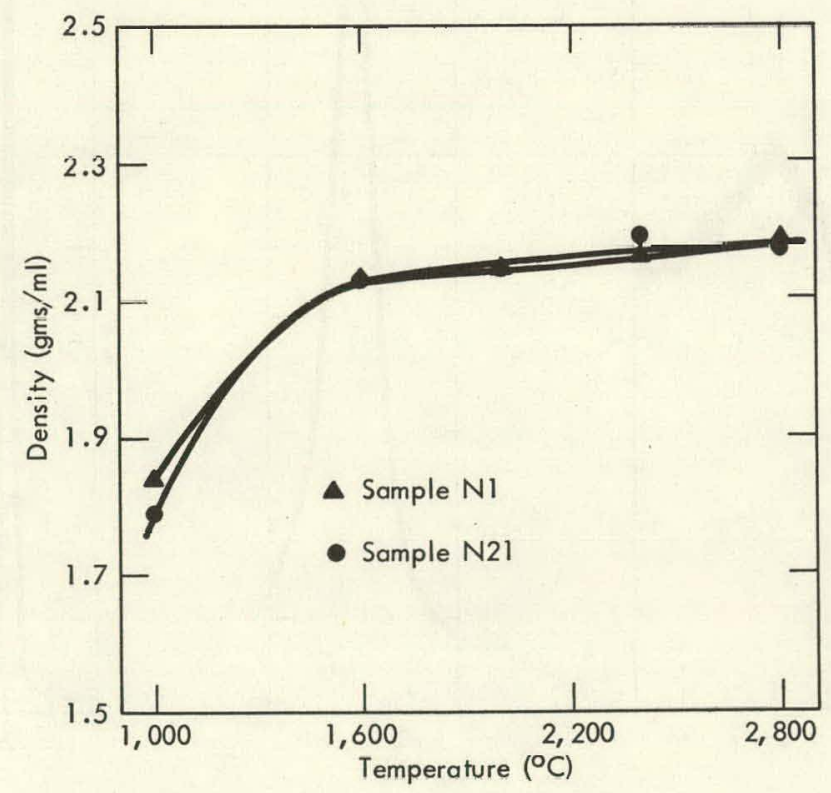

Figure 49. DENSITY OF CARBON DERIVED FROM AIRCURED ISOTRUXENE AS A FUNCTION OF THE FIRING TEMPERATURE. 


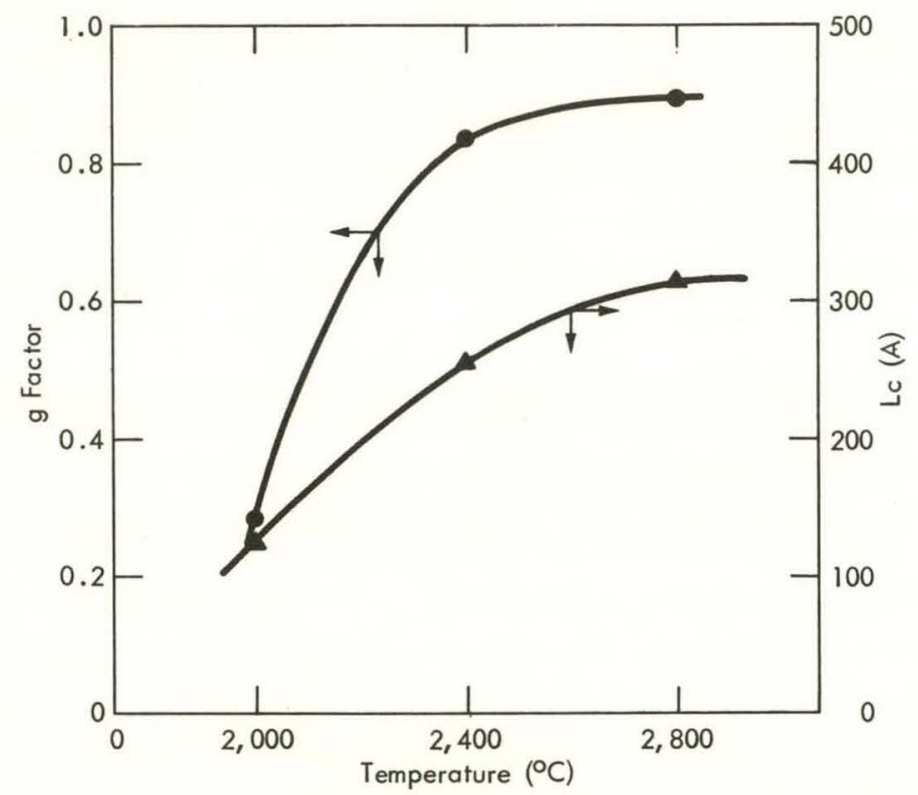

Figure 50. GRAPHITICITY AND CRYSTALLITE SIZE OF CARBON SAMPLES DERIVED FROM AIR-CURED ISOTRUXENE AS FUNCTIONS OF THE FIRING TEMPERATURE.
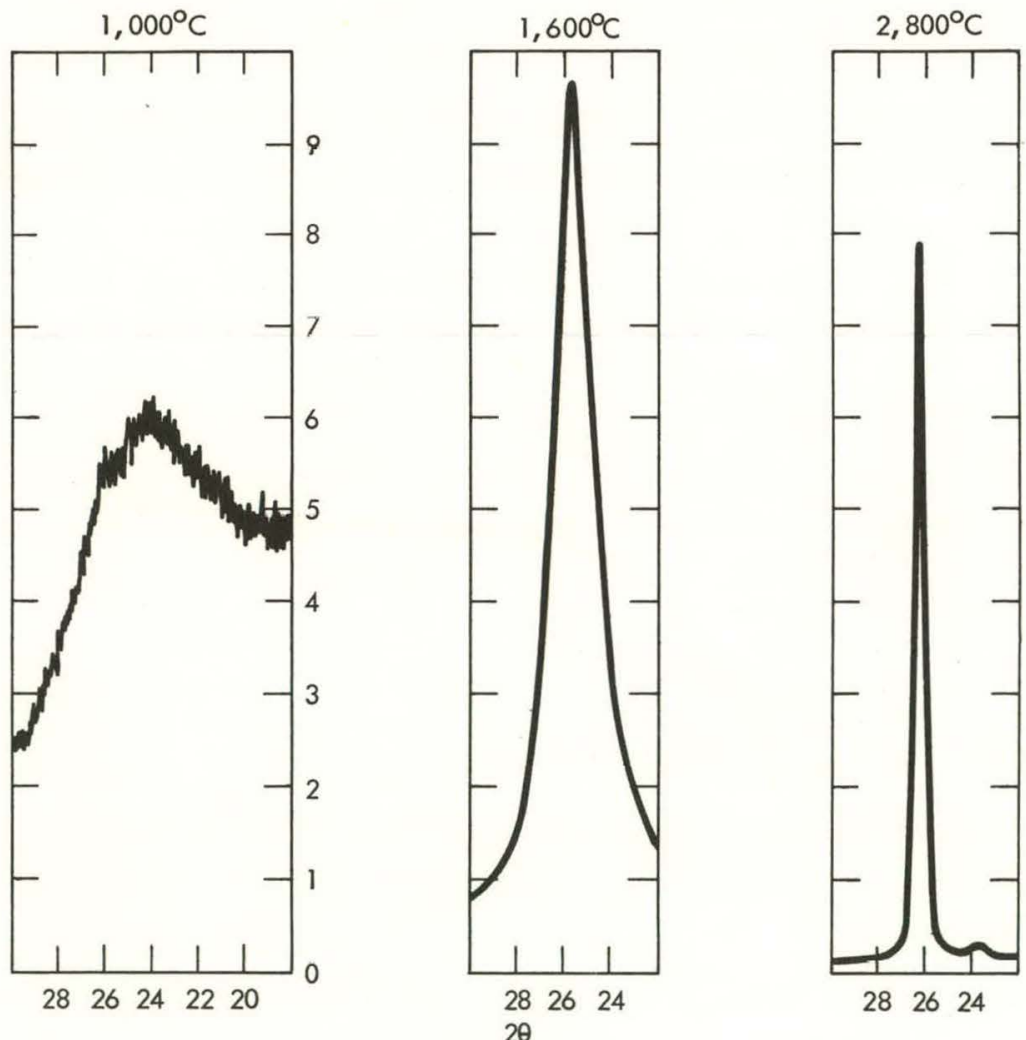

Figure 51. X-RAY DIFFRACTION SCANS (002 PLANE) OF CARBON SAMPLES DERIVED FROM AIR-CURED ISOTRUXENE AS A FUNCTION OF THE FIRING TEMPERATURE. 


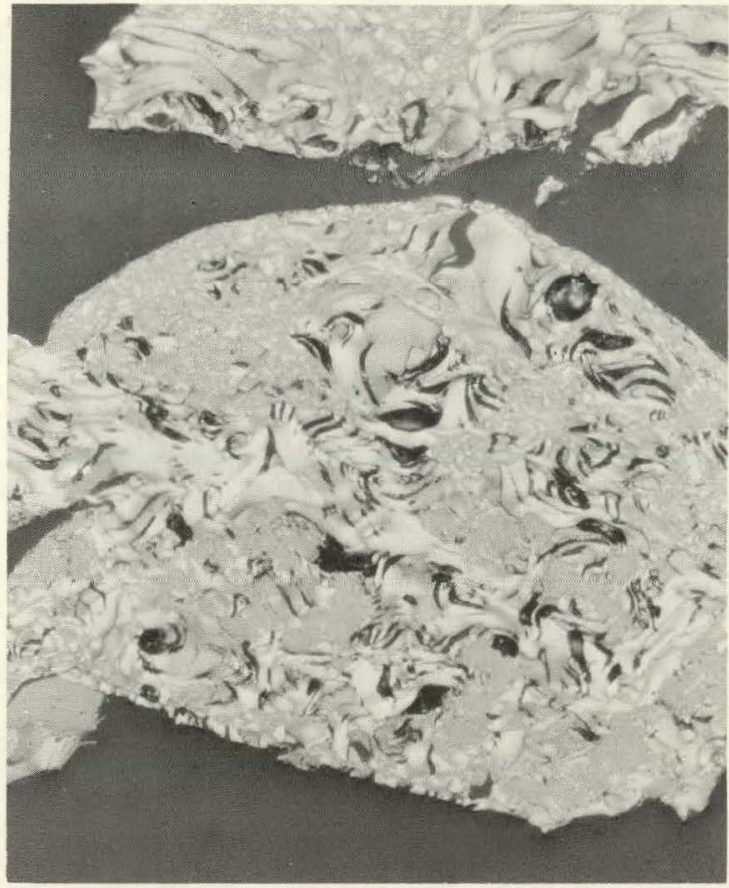

(a) At $1,600^{\circ} \mathrm{C}$

F107-1

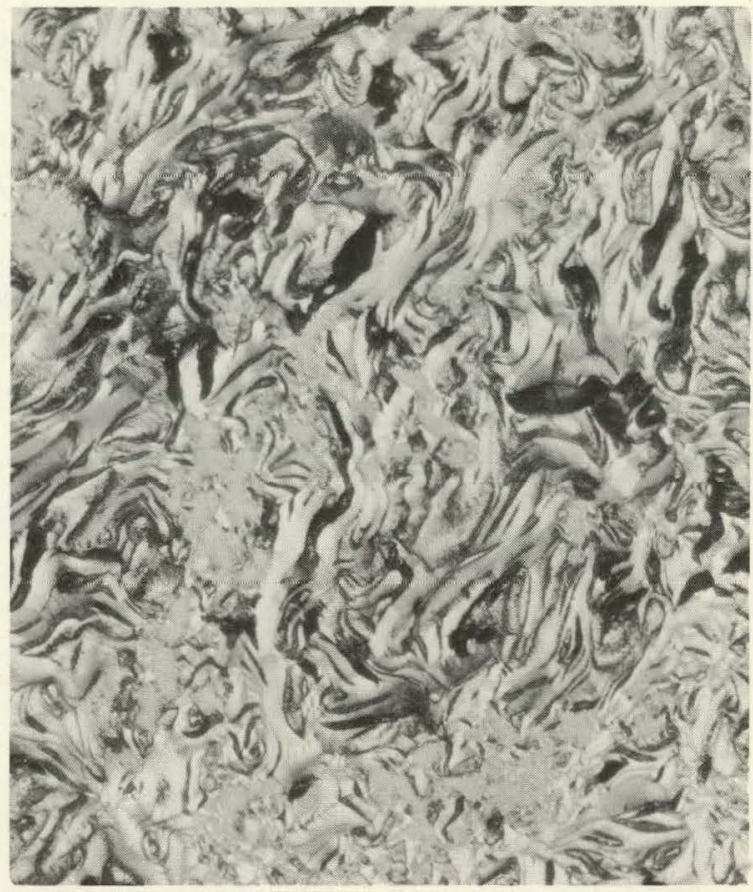

(b) At $2,000^{\circ} \mathrm{C}$

F107-2

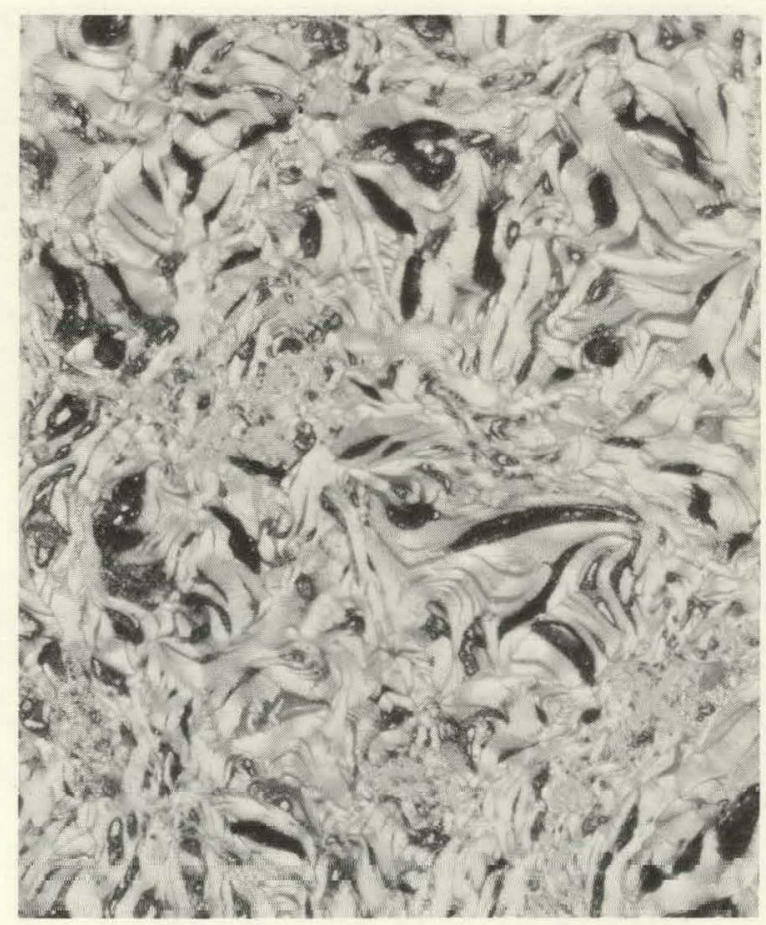

(c) At $2,400^{\circ} \mathrm{C}$

F107-3

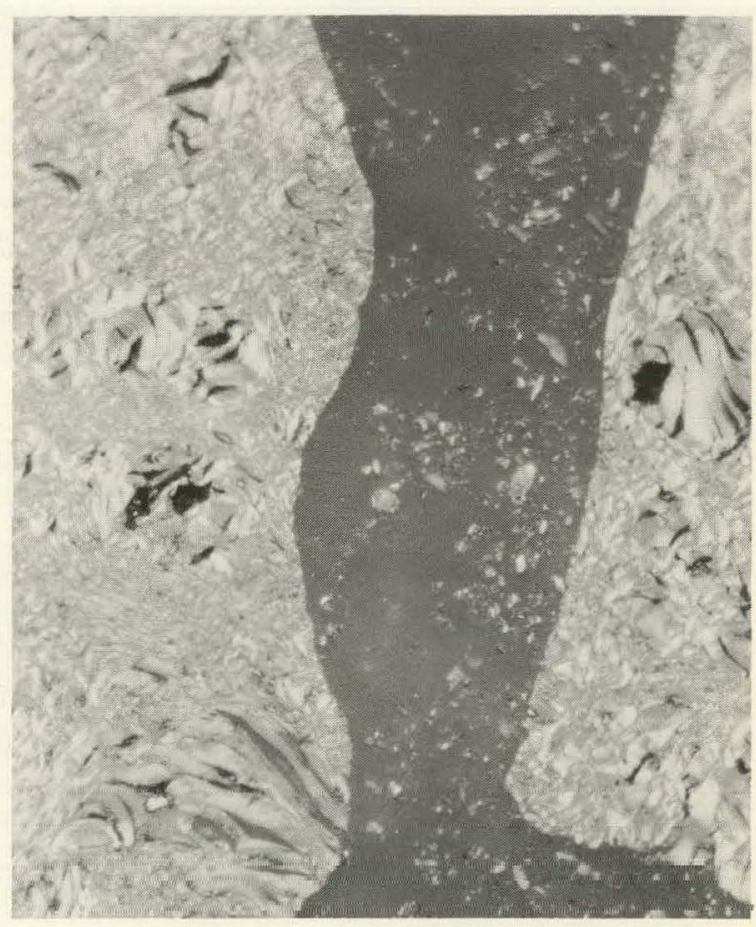

(d) At $2,800^{\circ} \mathrm{C}$

E188-1

Figure 52. MICROSTRUCTURES OF CARBON SAMPLES DERIVED FROM AIR-CURED ISOTRUXENE. (Batch 9-53-67- -N21; 250X) 
Heat Treatment at $300^{\circ} \mathrm{C}$ under Inert Gas - In order to compare the effect of heat treatment in oxidative atmospheres, ITX was heated at $300^{\circ} \mathrm{C}$ under argon for a total of 168 hours. As indicated by the physical properties listed in Table 20, there was little change in the polymer due to this heat treatment. The decrease in oxygen content denotes volatilization of the oxygen-containing contaminants. The increase in ITX content with heating time may be explained by the formation of ITX due to thermal decomposition of the tetrameric phase previously described (see Page 64). The data in Figure 53 showing the molecular distribution of samples before and after heat treatment support this contention.

Table 20

EFFECT OF HEAT TREATMENT $\left(300^{\circ} \mathrm{C}\right)$ IN AN INERT ATMOSPHERE ON THE PROPERTIES OF ISOTRUXENE AND ISOTRUXENE-DERIVED CARBON

\begin{tabular}{|c|c|c|c|c|c|c|c|c|}
\hline \multirow[b]{2}{*}{$\begin{array}{l}\text { Time } \\
\text { (hrs) }\end{array}$} & \multirow[b]{2}{*}{$\begin{array}{c}\text { Viscosity (1) } \\
\text { (cp) }\end{array}$} & \multirow{2}{*}{$\begin{array}{c}\text { Oxygen } \\
\text { Content (2) } \\
(\%)\end{array}$} & \multirow{2}{*}{$\begin{array}{l}\text { Melting } \\
\text { Range } \\
\left({ }^{\circ} \mathrm{C}\right)\end{array}$} & \multirow{2}{*}{$\begin{array}{l}\text { Apparent } \\
\text { ITX } \\
\text { Content (3) } \\
(\%)\end{array}$} & \multirow{2}{*}{$\begin{array}{c}\text { Coke Yield } \\
\text { at } \\
1,000^{\circ} \mathrm{C} \\
(\%)\end{array}$} & \multicolumn{3}{|c|}{$\begin{array}{c}\text { Carbon Properties } \\
\text { After } 2,800^{\circ} \mathrm{C}\end{array}$} \\
\hline & & & & & & $\begin{array}{l}\text { do04 } \\
\text { (A) }\end{array}$ & $\mathrm{g}$ factor & $\begin{array}{l}\mathrm{L}_{\mathrm{C}} \\
(\mathrm{A})\end{array}$ \\
\hline 0 & 18 & 0.3 & $202-212$ & 66 & 25 & 1.6986 & 0.506 & 99 \\
\hline 24 & 18 & & $180-208$ & & & & & \\
\hline 48 & 20 & & $185-212$ & & & & & \\
\hline 72 & 20 & 0.1 & $178-210$ & 93 & 31 & 1.6969 & 0.541 & 114 \\
\hline 99 & 18 & & & & & & & \\
\hline 142 & 19 & & & & & & & \\
\hline 168 & 20 & 0.1 & $183-214$ & 91 & 45 & 1.6998 & 0.471 & $155(?)$ \\
\hline
\end{tabular}

(1) Measured with Brookfield viscometer at $300^{\circ} \mathrm{C}$.

(2) Delermined by neutron activation.

(3) GPC analysis indicated a starting isotruxene content of $66 \%$.

Increases in coke yields may be attributed to the loss of volatiles during heating since these losses were not considered in calculating the cokeyield values.

Included in Table 20 is a list of the properties of carbon derived from three of the heat-treated samples. As indicated, the carbon properties did not change appreciably with the heating time. A microstructure of the sample corresponding to a heating time of 72 hours is shown in Figure 54, and was typical of the microstructures of these samples.

As would be expected, these microstructures were also similar to that depicted in Figure 43 for an ITX sample that received no prior heat treatment. 


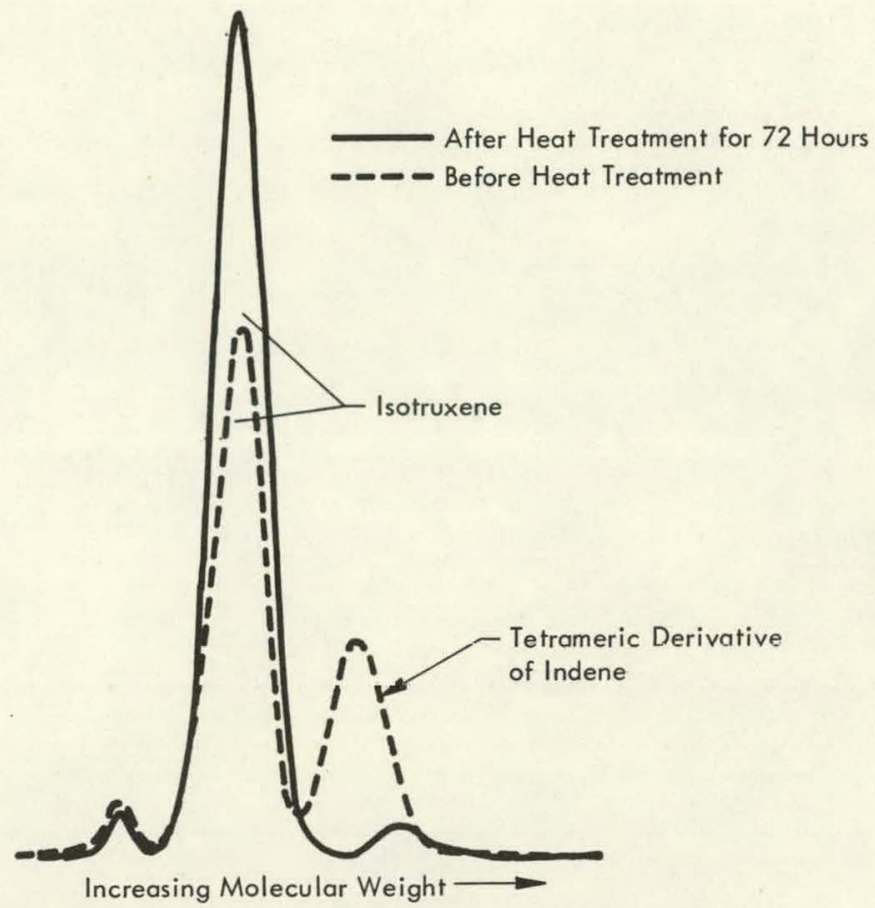

Figure 53. GEL PERMEATION CHROMATOGRAPHY SCANS SHOWING THE MOLECULAR DISTRIBUTION OF AN ISOTRUXENE PRODUCT (INITIALLY CONTAINED $66 \%$ ITX) BEFORE AND AFTER HEAT TREATMENT UNDER ARGON AT $300^{\circ} \mathrm{C}$.

Heat Treatment at $300^{\circ} \mathrm{C}$ in Air-Samples of ITX were oxidatively polymerized by heating at $300^{\circ} \mathrm{C}$ with an air flow of $360 \mathrm{cc} / \mathrm{min}$ bubbling through the molten material. Changes in polymer properties with heating time are reported in Table 21. The ITX sample used for this study was that isolated after the heat-treatment experiment in an inert atmosphere, as previously described. Increases in the heat-treatment time in air were accompanied by increases in viscosity, oxygen content, and coke yield. The expected decrease in ITX monomer content was followed by GPC analyses. As polymerization proceeded and the crystallinity of the material decreased, an initial depression in the melting point was observed. This depression is followed by increases in the melting temperature if the heating period is extended, as was done in this experiment.

Properties of carbons derived from these polymers are included in Table 21. In general, changes in the carbon properties with the polymer heat-treatment time were quite significant during the initial 50 hours. Extended heating had little or no influence on these properties, but did, however, result in some additional increase in the coke yield. The changes in $\mathrm{g}$ factor and crystallite size are shown as a function of viscosity in 


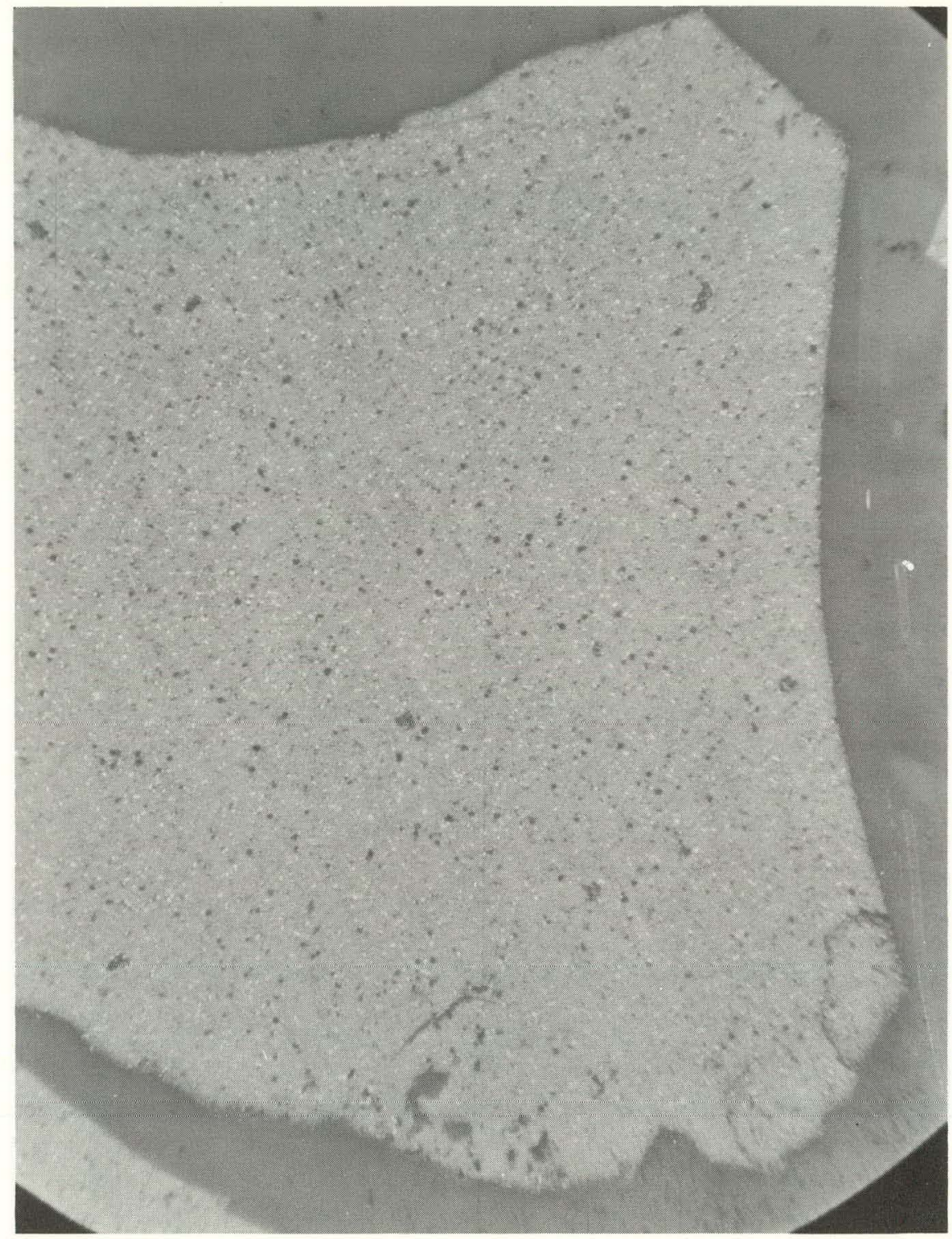

F760-5

Figure 54. MICROSTRUCTURE OF A CARBON STRUCTURE (AFTER 2,800 C) DERIVED FROM ISOTRUXENE AFTER HEAT TREATMENT UNDER ARGON FOR 72 HOURS AT $300^{\circ} \mathrm{C}$. (250X)

Figure 55. Microstructures of the carbon samples corresponding to the various heat-treatment times are seen in Figure 56. Changes in the microstructure during the early part of the heating period parallel the property changes previously cited. The sequence of photomicrographs show an initial change from a fine-grain, uniform texture to a less homogeneous, coarse-grain graphite; and, finally, to a relatively even-textured material of much smaller grain size. 
Table 21

EFFECT OF HEAT TREATMENT $\left(300^{\circ} \mathrm{C}\right.$ ) IN AIR (FLOW RATE OF $360 \mathrm{CC} / \mathrm{MIN}$ ) ON THE PROPERTIES OF ISOTRUXENE AND ISOTRUXENE-DERIVED CARBON

\begin{tabular}{|c|c|c|c|c|c|c|c|c|}
\hline \multirow[b]{2}{*}{$\begin{array}{c}\text { Time (1) } \\
\text { (hrs) }\end{array}$} & \multirow[b]{2}{*}{$\begin{array}{l}\text { Viscosity }(2) \\
\text { (cp) }\end{array}$} & \multirow{2}{*}{$\begin{array}{c}\text { Oxygen } \\
\text { Content(3) } \\
(\%)\end{array}$} & \multirow{2}{*}{$\begin{array}{c}\text { Melting } \\
\text { Range } \\
\left({ }^{\circ} \mathrm{C}\right)\end{array}$} & \multirow{2}{*}{$\begin{array}{c}\text { Apparent } \\
\text { ITX } \\
\text { Content (4) } \\
(\%)\end{array}$} & \multirow{2}{*}{$\begin{array}{c}\text { Coke Yield } \\
\text { After } \\
1,000^{\circ} \mathrm{C} \\
(\%)\end{array}$} & \multicolumn{3}{|c|}{$\begin{array}{c}\text { Carbon Properties } \\
\text { After } 2,800^{\circ} \mathrm{C}\end{array}$} \\
\hline & & & & & & $\begin{array}{l}\mathrm{d} 004 \\
(\mathrm{~A})\end{array}$ & $\mathrm{g}$ factor & $\begin{array}{l}L_{c} \\
(A)\end{array}$ \\
\hline 0 & 20 & 0.1 & $183-214$ & 91 & 45 & 1.6998 & 0.471 & 155 \\
\hline 24 & 28 & 0.3 & $92-184$ & 79 & 42 & 1.6934 & 0.624 & 91 \\
\hline 48 & 41 & 0.5 & $93-128$ & 71 & 43 & 1.6906 & 0.694 & 108 \\
\hline 81 & 109 & 0.6 & $130-161$ & 63 & 61 & 1.6906 & 0.694 & 108 \\
\hline 106 & 177 & 0.6 & $138-172$ & 58 & 63 & 1.6908 & 0.682 & 107 \\
\hline 120 & 295 & 0.6 & $144-180$ & 62 & & 1.6923 & 0.647 & 96 \\
\hline
\end{tabular}

(1) Air bubbled through the molten isotruxene with continuous agitation; viscosity measured periodically and sample simultaneously removed for evaluation.

(2) Measured at $300^{\circ} \mathrm{C}$ using a Brookfield viscometer.

(3) Determined by neutron activation.

(4) Estimated from molecular distribution on GPC scans.

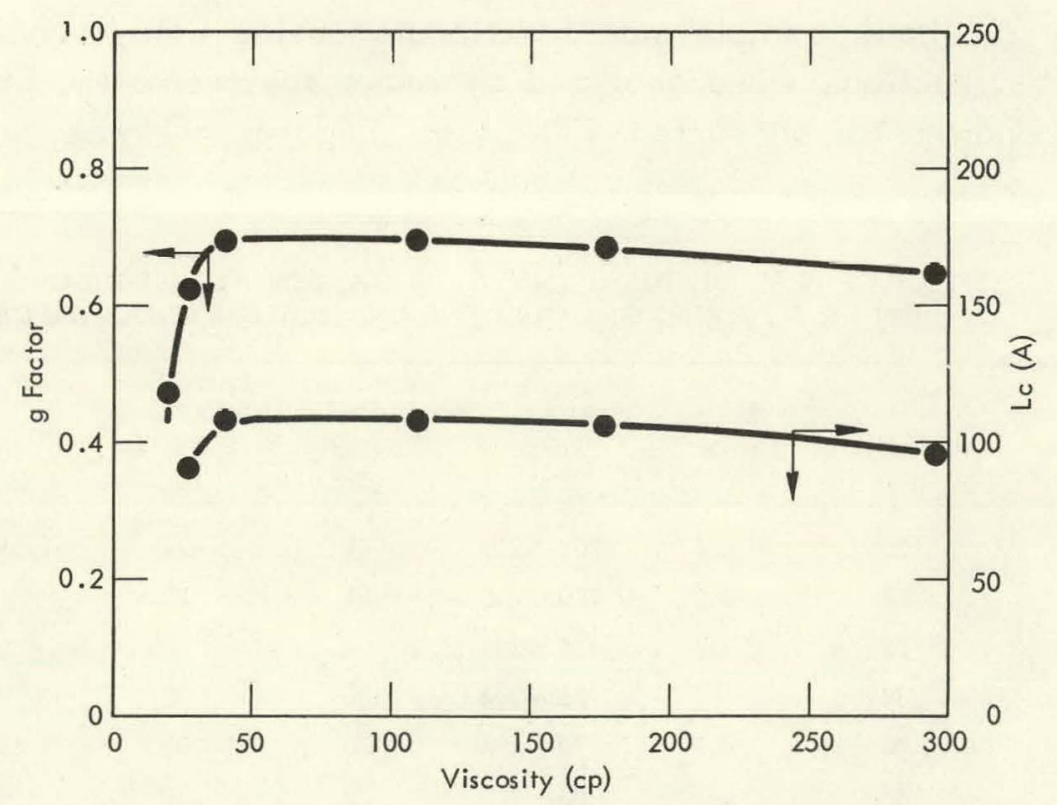

Figure 55. GRAPHITICITY AND CRYSTALLITE SIZE OF CARBON SAMPLES (AFTER 2,800 C) DERIVED FROM ISOTRUXENE AS FUNCTIONS OF THE VISCOSITY (AT $300^{\circ}$ C) ON HEAT TREATMENT IN AIR. (Flow Rate, 360 $\mathrm{cc} / \mathrm{min})$

Thus, it is apparent from this experiment that oxidative curing of ITX significantly affects the polymer properties and, to a lesser degree, those of the derived carbon. As a consequence, variation in the heat-cure conditions will allow some control over the polymer and carbon properties. 
Heat Treatment at $245^{\circ} \mathrm{C}$ in Oxygen - One sample of ITX was heated at $245^{\circ} \mathrm{C}$ with continuous agitation and with an oxygen gas flow rate of $40 \mathrm{cc} / \mathrm{min}$ through the molten material. Data on samples that were taken at various time intervals are reported in Table 22. Changes in the polymer properties proceeded at a much slower rate than observed for the $300^{\circ} \mathrm{C}$ air-cured sample previously discussed. A lower temperature and a lower gas-flow rate (with respect to oxygen) may be cited as reasons for the slower rate of change. However, at this slower polymerization rate, the oxygen taken up was significantly greater than for the $300^{\circ} \mathrm{C}$ air-cured sample. Gel permeation chromatography scans showing the molecular distribution after heat-treatment times of 19, 100, and 256 hours are presented in Figure 57. As previously mentioned, oxidative polymerization of ITX results in an initial depression in the melting temperature. The change in melting properties with heating time is depicted in Figure 58 for the $245^{\circ} \mathrm{C}$ oxygen-cured sample. As indicated in Figure 58, some of the rapidly cooled samples that appeared to be amorphous were observed to recrystallize after initially melting.

The 256-hour sample was fractionated using GPC techniques, and each of the fractions were analyzed by mass spectrometry. The fraction corresponding to unreacted ITX (see Figure 57) was mostly mass-342

Table 22

EFFECT OF HEAT TREATMENT $\left(245^{\circ} \mathrm{C}\right.$ ) IN OXYGEN (FLOW RATE OF $40 \mathrm{CC} / \mathrm{MIN}$ ) ON THE PROPERTIES OF ISOTRUXENE AND ISOTRUXENE-DERIVED CARBON

\begin{tabular}{|c|c|c|c|c|c|c|c|c|}
\hline \multirow[b]{2}{*}{$\begin{array}{l}\text { Time } \\
\text { (hrs) }\end{array}$} & \multirow[b]{2}{*}{$\begin{array}{l}\text { Viscosity }(1) \\
\text { (cp) }\end{array}$} & \multirow{2}{*}{$\begin{array}{l}\text { Oxygen } \\
\text { Content (2) } \\
(\%)\end{array}$} & \multirow{2}{*}{$\begin{array}{l}\text { Melting } \\
\text { Range } \\
(\circ \mathrm{C})\end{array}$} & \multirow{2}{*}{$\begin{array}{c}\text { Apparent } \\
\text { ITX } \\
\text { Content (3) } \\
(\%)\end{array}$} & \multirow{2}{*}{$\begin{array}{c}\text { Coke Yield } \\
\text { After } \\
1,000^{\circ} \mathrm{C} \\
(\%)\end{array}$} & \multicolumn{3}{|c|}{$\begin{array}{c}\text { Carbon Properties } \\
\text { After } 2,800^{\circ} \mathrm{C}\end{array}$} \\
\hline & & & & & & $\begin{array}{l}\mathrm{d} 004 \\
\text { (A) }\end{array}$ & $\mathrm{g}$ factor & $\begin{array}{l}L_{C} \\
(A)\end{array}$ \\
\hline 0 & 25 & 0.3 & $208-216$ & 71 & 24 & 1.6995 & 0.482 & 110 \\
\hline 19 & 27 & 0.5 & $170-215$ & 91 & 29 & & & \\
\hline 27 & 32 & & $135-206$ & & & & & \\
\hline 52 & 34 & & $76-204$ & 90 & 32 & & & \\
\hline 76 & 40 & 0.7 & $78-196$ & 76 & 39 & 1.6882 & 0.753 & 134 \\
\hline 100 & 57 & 0.9 & $83-176$ & 73 & 50 & & & \\
\hline 140 & 73 & 1.0 & $93-130$ & 66 & 59 & 1.6894 & 0.718 & 118 \\
\hline 159 & 84 & 1.2 & $88-126$ & 64 & & & & \\
\hline 171.5 & 118 & 1.2 & $98-132$ & 59 & 65 & & & \\
\hline 184 & 131 & 1.4 & $106-138$ & 57 & & & & \\
\hline 208 & 173 & 1.5 & $108-148$ & 56 & 70 & 1.6851 & 0.824 & 181 \\
\hline 232 & 216 & 1.6 & $111-152$ & 52 & 71 & & & \\
\hline 256 & 514 & 1.7 & $126-162$ & 49 & 71 & 1.6865 & 0.788 & 289 \\
\hline
\end{tabular}

(1) Measured at $245^{\circ} \mathrm{C}$ using a Brookfield viscometer.

(2) Determined by neutron activation.

(3) Estimated from molecular distributions obtained from GPC scans. 

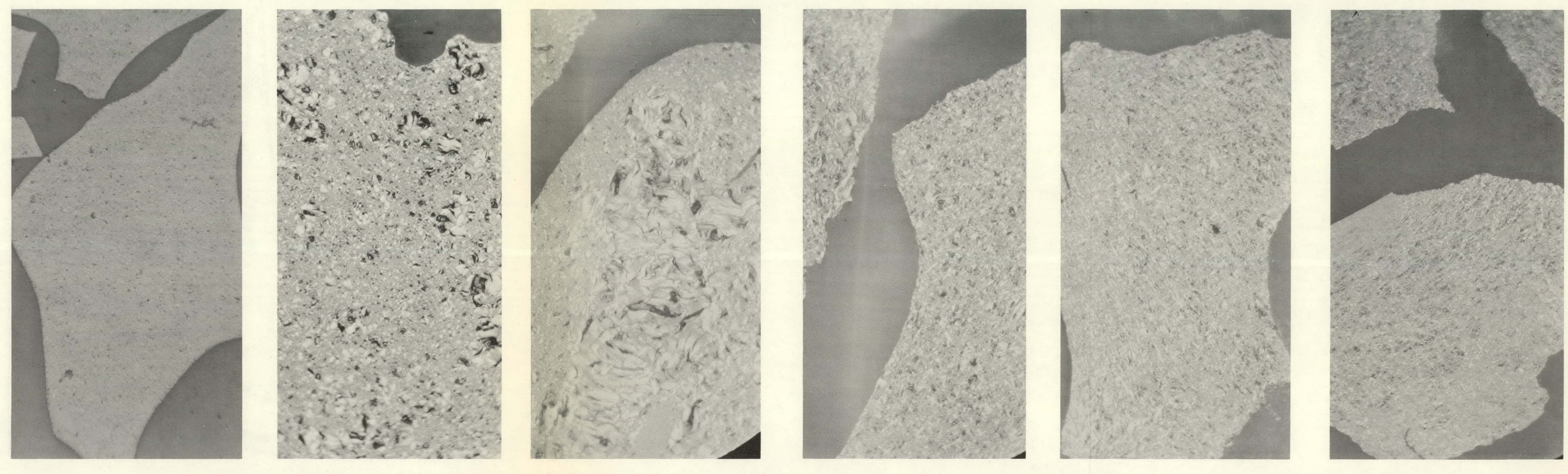

(a) Affer $\mathrm{OHour}$

F760-6

(b) After 24 Hours

F681-7

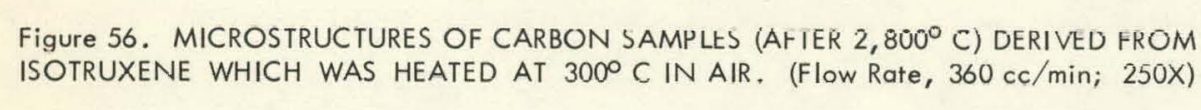




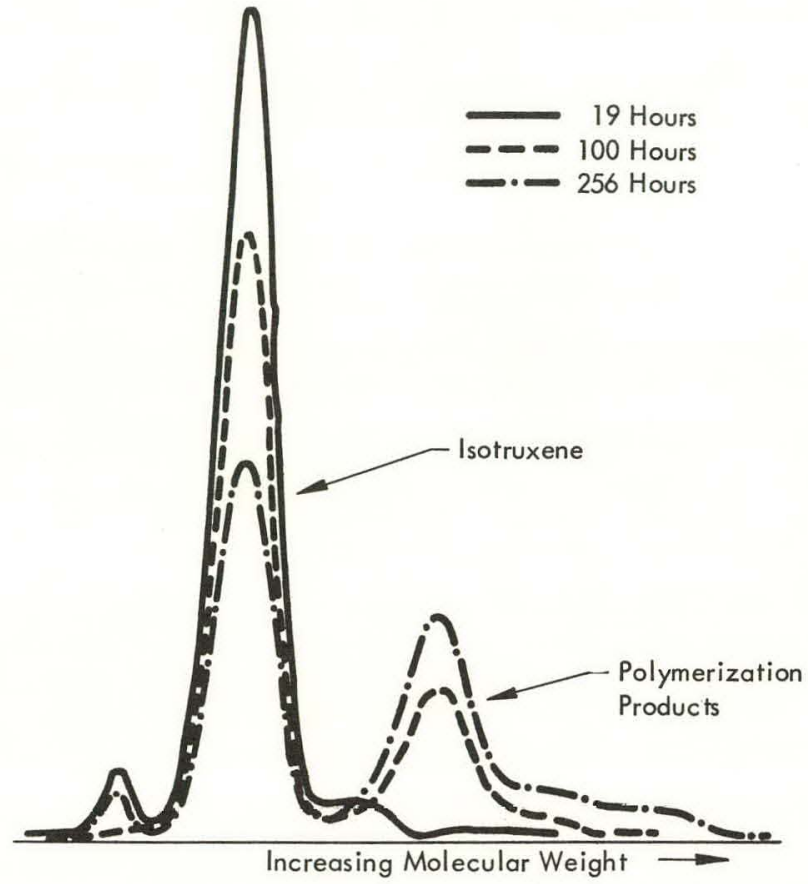

Figure 57. GEL PERMEATION CHROMATOGRAPHY SCANS SHOWING THE MOLECULAR DISTRIBUTION OF ISOTRUXENE ON HEATING AT $245^{\circ} \mathrm{C}$ IN THE PRESENCE OF OXYGEN GAS. (Flow Rate, $40 \mathrm{cc} / \mathrm{min}$ )

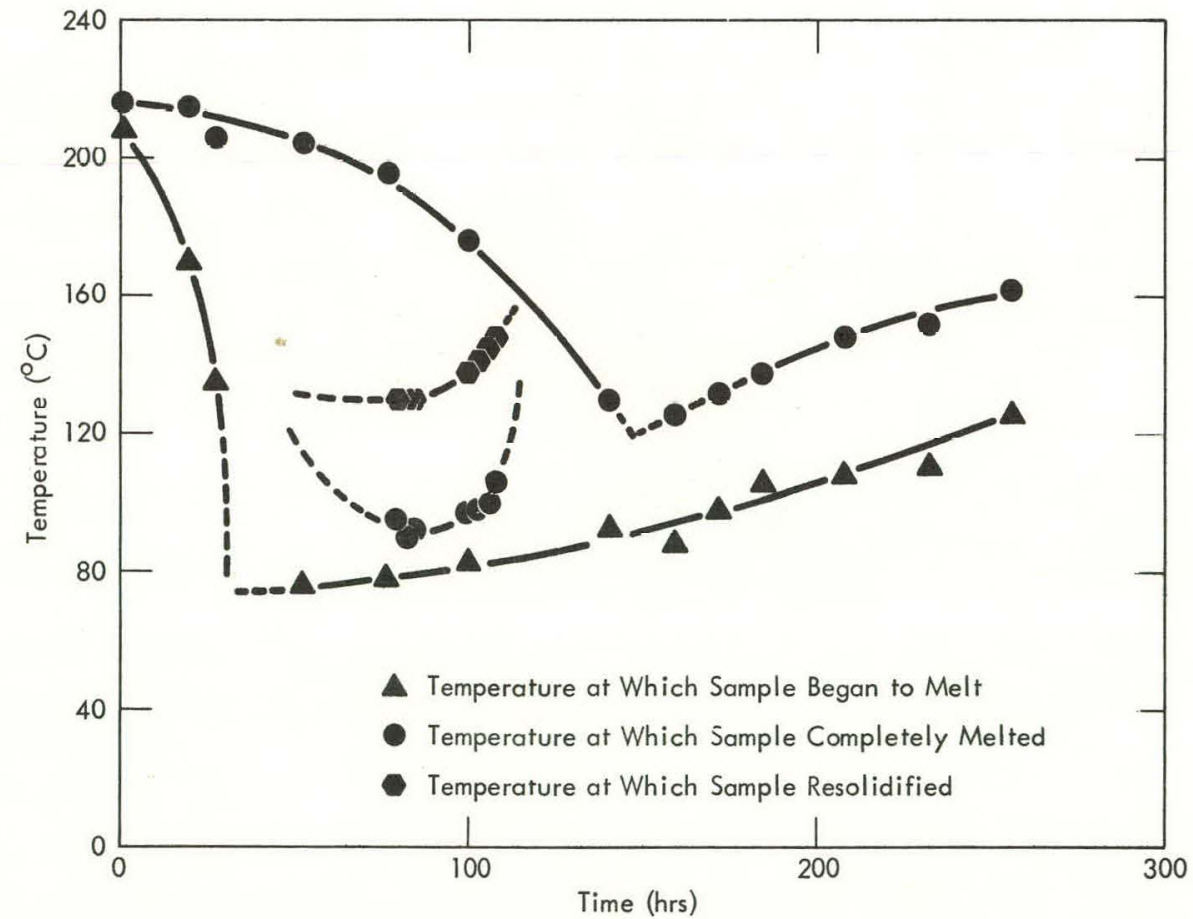

Figure 58. FUSION PROPERTIES OF ISOTRUXENE AS A FUNCTION OF THE HEATTREATMENT TIME AT $245^{\circ} \mathrm{C}$ IN THE PRESENCE OF OXYGEN GAS. (Flow Rate, 40 $\mathrm{cc} / \mathrm{min}$ ) 
material, as would be expected from isotruxene. A much smaller amount of mass-356 material $(<10 \%)$ was detected. The latter compound would correspond to an oxidation product in which one oxygen atom displaced two atoms of hydrogen.

A second fraction corresponding to the polymeric phase in Figure 57 included various oxidation products in addition to isotruxene. Masses corresponding to 356,370 , and 384 were present in decreasing quantities, and indicated the presence of one, two, and three oxygen atoms per molecule of ITX. These oxygen atoms are probably present as carbonyl groups at each of the three methylene carbon sites. The presence of other higher molecular weight products (up to mass 560) was indicated, but no structural characterizations were attempted.

Properties of carbon derived from these heat-treated ITX samples are included in Table 22. Increases in the graphitic nature of the carbon with increasing heating time is apparent. This trend is further indicated by the sequence of microstructures shown in Figure 59.

Heat Treatment at $300^{\circ} \mathrm{C}$ in Oxygen - Three ITX samples were heated at $300^{\circ} \mathrm{C}$, with constant agitation, but at different oxygen flow rates. Used were flow rates of 40,84 , and $165 \mathrm{cc} / \mathrm{min}$. Samples were removed periodically for evaluation. Data on these experiments are included in Table 23. Figure 60 allows a comparison to be made of the viscositymelting temperature (upper limit of range) relationships for samples heated under three different temperature flow-rate combinations. The data in Figure 60 indicate that: (1) the minimum-melting-point values were independent of the heat-treatment temperature, but were directly proportional to the oxygen flow rate; and (2) that viscosities of the minimum-melting materials were independent of the oxygen flow rate.

In Figure 61, viscosities are shown as a function of the heat-treatment time for samples heated under various temperature and flow-rate conditions. The following observations were made: (1) heating under inert atmospheres at $300^{\circ} \mathrm{C}$ does not promote polymerization, but heating in oxidizing atmospheres does; (2) increases in the heating temperature increases the rate of polymerization, as indicated by comparing samples heated at the same oxygen flow rate but at different temperatures (245 and $\left.300^{\circ} \mathrm{C}\right) ;(3)$ increasing the oxygen flow rate increases the polymerization rate, as indicated by comparing samples heated at $300^{\circ} \mathrm{C}$ but at different flow rates $(40,84$, and $165 \mathrm{cc} / \mathrm{min})$. 
Table 23

EFFECT OF HEAT TREATMENT $\left(300^{\circ} \mathrm{C}\right)$ IN OXYGEN ON THE PROPERTIES OF ISOTRUXENE AND ISOTRUXENE-DERIVED CARBON

\begin{tabular}{|c|c|c|c|c|c|c|c|c|}
\hline \multirow[b]{2}{*}{$\begin{array}{l}\text { Time } \\
\text { (hrs) }\end{array}$} & \multirow[b]{2}{*}{$\begin{array}{c}\text { Viscosity (1) } \\
(\mathrm{cp})\end{array}$} & \multirow{2}{*}{$\begin{array}{l}\text { Oxygen } \\
\text { Content (2) } \\
(\%)\end{array}$} & \multirow{2}{*}{$\begin{array}{c}\text { Melting } \\
\text { Range } \\
\left({ }^{\circ} \mathrm{C}\right)\end{array}$} & \multirow{2}{*}{$\begin{array}{c}\text { Apparent } \\
\text { ITX } \\
\text { Content (3) } \\
(\%) \\
\end{array}$} & \multirow{2}{*}{$\begin{array}{c}\text { Coke Yield } \\
\text { After } \\
1,000^{\circ} \mathrm{C} \\
(\%)\end{array}$} & \multicolumn{3}{|c|}{$\begin{array}{c}\text { Carbon Properties } \\
\text { After } 2,800^{\circ} \mathrm{C}\end{array}$} \\
\hline & & & & & & $\begin{array}{l}\mathrm{d} 004 \\
(\mathrm{~A})\end{array}$ & $\mathrm{g}$ factor & $\begin{array}{l}\mathrm{L}_{\mathrm{c}} \\
(\mathrm{A})\end{array}$ \\
\hline \multicolumn{9}{|c|}{ Batch $10-82-69\left(\mathrm{O}_{2}\right.$ Flow Rate, $\left.40 \mathrm{cc} / \mathrm{min}\right)$} \\
\hline 0 & 18 & 0.2 & $202-212$ & 79 & 39 & 1.7010 & 0.447 & 120 \\
\hline 24 & 22 & 0.4 & $78-187$ & 81 & 43 & 1.6906 & 0.694 & 104 \\
\hline 48 & 32 & 0.7 & $89-123$ & ו & 62 & 1.6914 & 0.671 & 112 \\
\hline 72 & 57 & 1.1 & $93-142$ & 65 & 64 & 1.6854 & 0.812 & 187 \\
\hline 96 & 113 & 1.3 & $135-183$ & 59 & 75 & 1.6860 & 0.800 & 187 \\
\hline 125 & 427 & 1.4 & $182-196$ & 58 & 78 & 1.6865 & 0.788 & 178 \\
\hline \multicolumn{9}{|c|}{ Batch $10-84-69\left(\mathrm{O}_{2}\right.$ Flow Rate, $\left.84 \mathrm{cc} / \mathrm{min}\right)$} \\
\hline 0 & 17 & 0.3 & $201-209$ & 83 & 45 & 1.7025 & 0.412 & 97 \\
\hline 24 & 26 & 0.9 & $85-178$ & 79 & 64 & 1.6900 & 0.706 & 102 \\
\hline 48 & 61 & 1.3 & $123-163$ & 64 & 62 & 1.6871 & 0.776 & 131 \\
\hline 72 & 138 & 1.2 & $132-168$ & 60 & 74 & 1.6845 & 0.835 & 200 \\
\hline 91 & 627 & 1.1 & $184-222$ & 59 & 84 & 1.6851 & 0.824 & 173 \\
\hline \multicolumn{9}{|c|}{ Batch 10-92-69 (O2 Flow Rate, $165 \mathrm{cc} / \mathrm{min})$} \\
\hline 0 & 18 & 0.2 & $208-216$ & 69 & 26 & 1.7004 & 0.459 & 112 \\
\hline 24 & 33 & 0.9 & $92-122$ & 75 & 61 & 1.6882 & 0.753 & 122 \\
\hline 48 & 108 & 1.5 & $143-178$ & 56 & 77 & 1.6871 & 0.776 & 198 \\
\hline $65(4)$ & - & 0.6 & $>300$ & (insoluble) & 90 & 1.6882 & 0.753 & 129 \\
\hline
\end{tabular}

(1) Measured with a Brooktield viscometer.

(2) Determined by neutron activation.

(3) Estimated from molecular distributions shown on the GPC scans.

(4) Material solidified after 65 hours of heating at $300^{\circ} \mathrm{C}$; thus, no viscosity was measured.

Oxygen take up is shown as a function of viscosity in Figure 62 for samples heated under the various conditions. As noted, the oxygen content increases quite markedly during the initial stages of the heating period, but approaches constant values after an extended period.

As indicated in Table 23, the ITX monomer content decreases during heat treatment in the presence of oxygen. Figure 63 shows the monomer content as a function of viscosity for samples heated under the various conditions. As can be seen, the monomer content decreases markedly with small initial increases in viscosity, but approaches constant values at higher viscosities. 

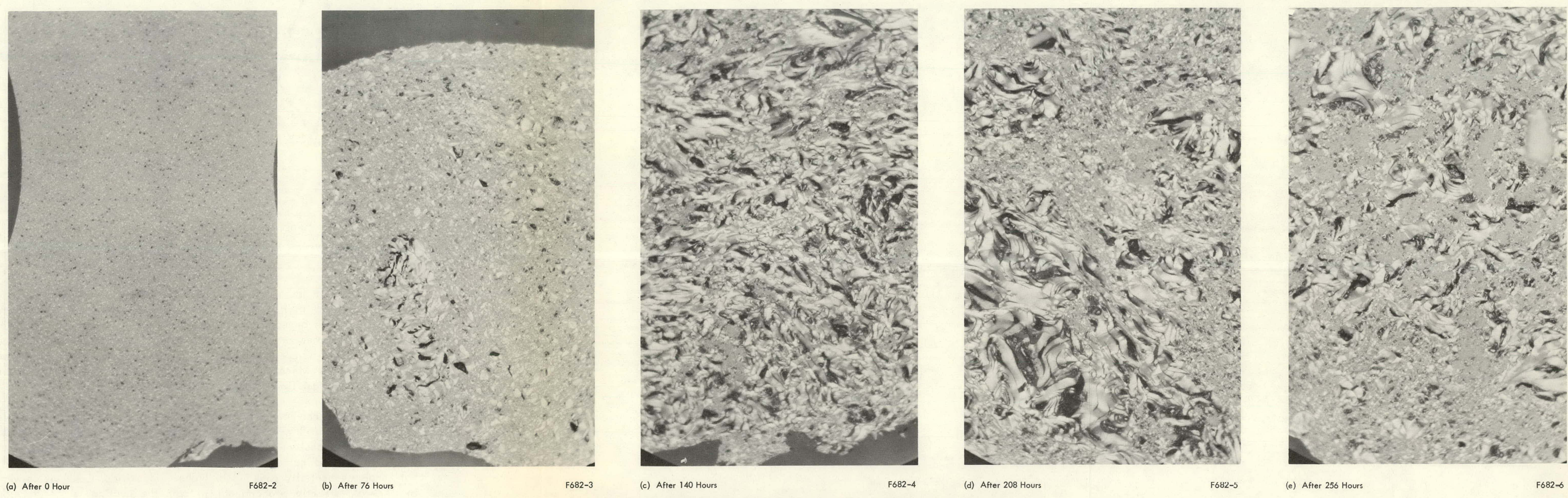

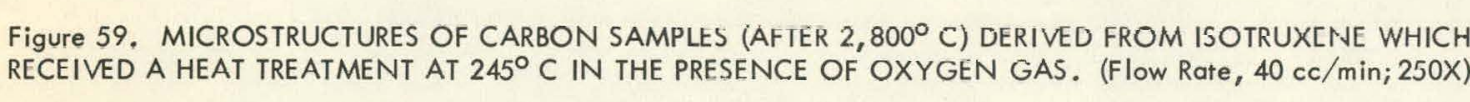




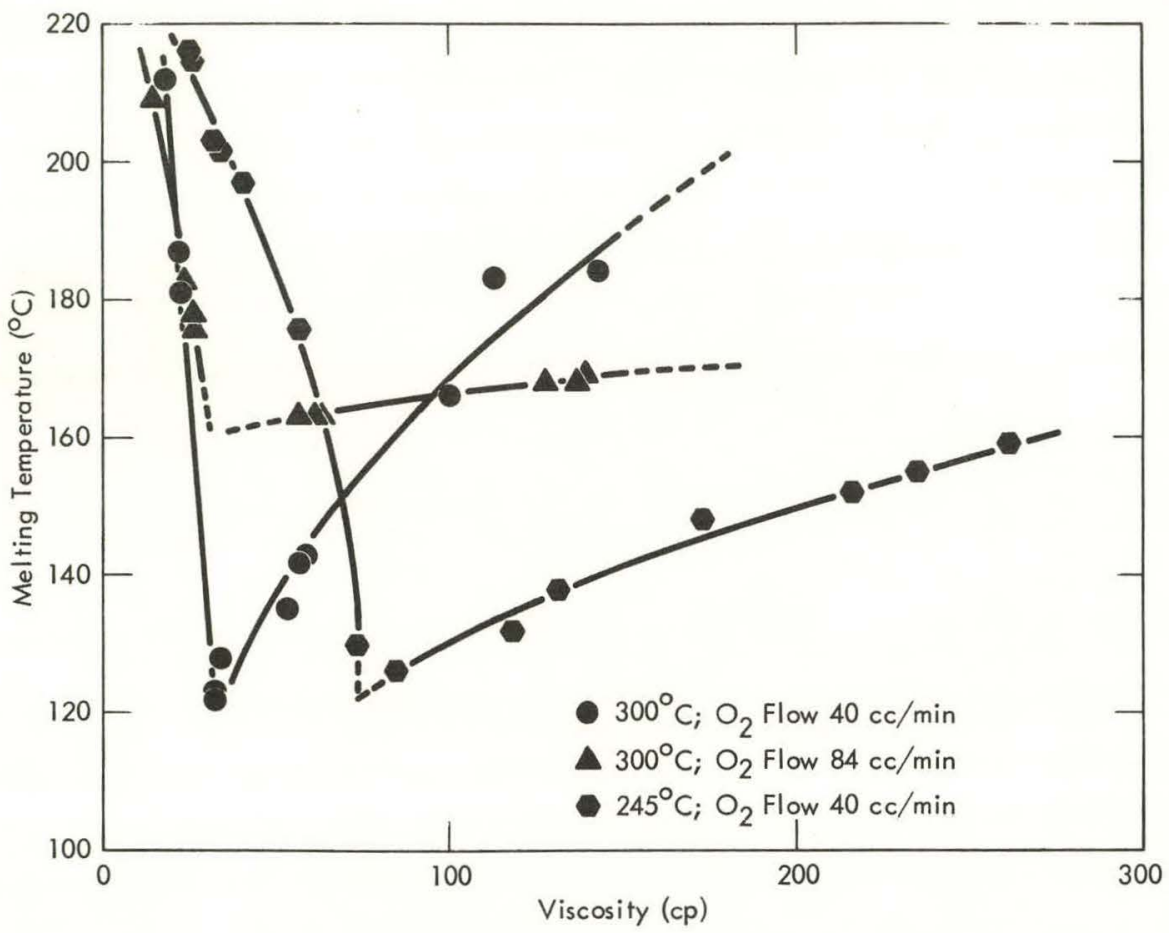

Figure 60. CORRELATIONS BETWEEN FUSION TEMPERATURES (UPPER LIMIT OF RANGE) AND VISCOSITIES (MEASURED AT THE HEAT-TREATMENT TEMPERATURE) OF ISOTRUXENE SAMPLES ON HEAT TREATMENT IN THE PRESENCE OF OXYGEN GAS.

A correlation of the melting temperature (upper limit) and monomer content is shown in Figure 64. The monomer content of the minimummelting materials appears to be independent of the oxygen flow rate, but is influenced somewhat by the heat-treatment temperature. On extended heating, melting temperatures increase with the decreasing monomer content at rates which are directly proportional to the heating temperature and the oxygen flow rate.

Properties of carbon derived from these oxidatively polymerized samples of isotruxene are included in Table 23. Coke yields are shown as a function of viscosity in Figure 65. At lower viscosities, coke-yield values increased rather markedly with small increases in viscosity, but became essentially constant at higher viscosities. Coke yields were, in general, directly proportional to both the heating temperature and the oxygen flow rate.

As is apparent in Figure 66, coke-yield values varied with the polymer composition, as expressed by the unreacted ITX content. Inflections in the curves appeared to be real, and represented compositions quite similar to those of the respective minimum-melting compositions. These 
compositions apparently contain intermediates which degrade more readily than other compositions evaluated.

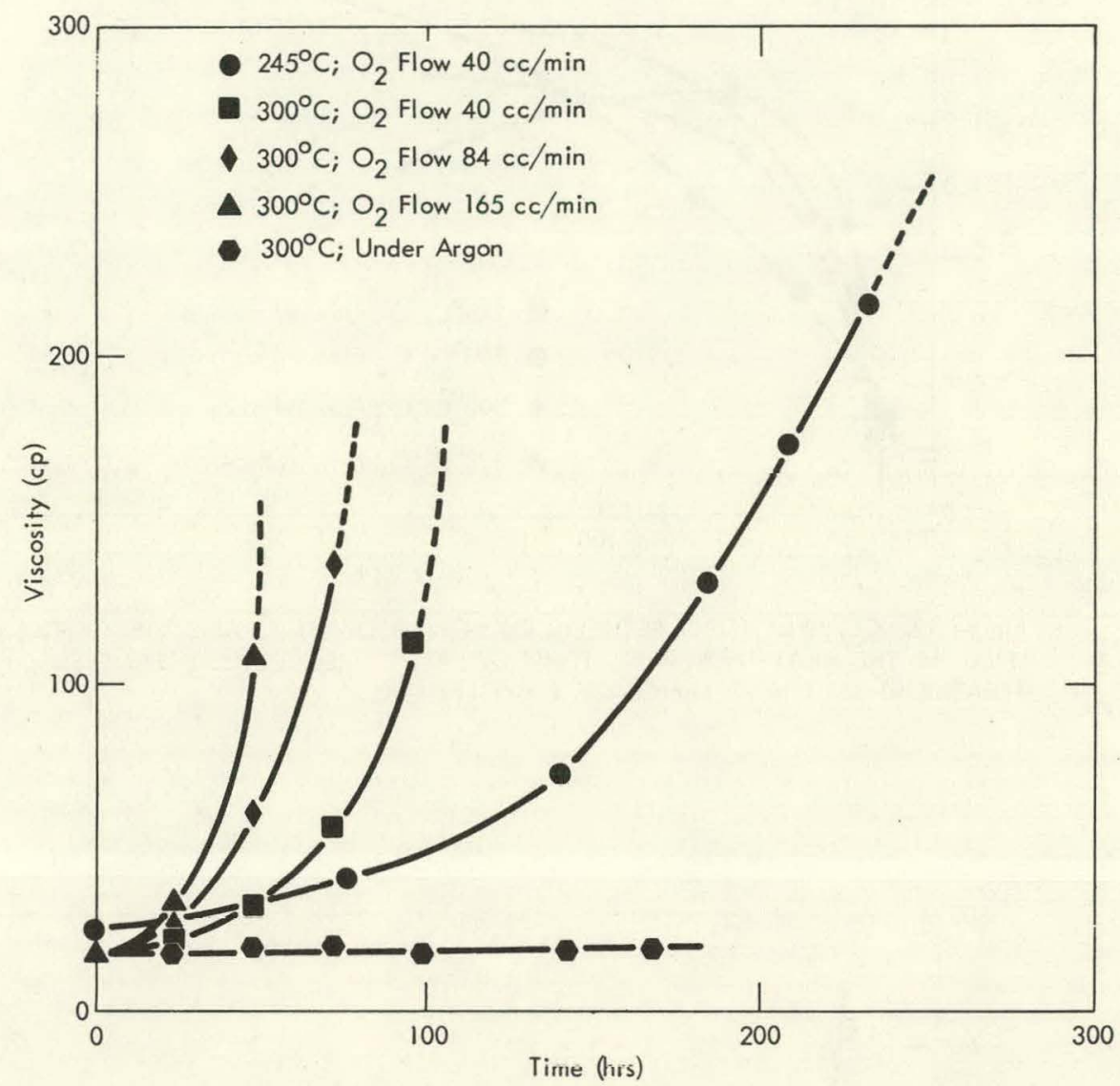

Figure 61. VISCOSITY OF ISOTRUXENE (MEASURED AT THE HEAT-TREATMENT TEMPERATURE) AS A FUNCTION OF THE HEAT-TREATMENT TIME IN THE PRESENCE OF OXYGEN GAS.

The graphiticity of carbons derived from these heat-treated samples of isotruxene increased significantly because of the oxidative polymerization, with major changes corresponding to the early heating periods. Changes in the g-factor and crystallite-size $\left(L_{c}\right)$ values are shown as a function of viscosity in Figure 67. As is apparent, a maximum for both properties was observed for samples corresponding to viscosities of approximately $100-150 \mathrm{cp}$ (as measured at $300^{\circ} \mathrm{C}$ ). At higher viscosities, values for both $g$ factor and crystallite size show gradual decreases.

Microstructures of the carbons derived from two sets of these $300^{\circ} \mathrm{C}$ oxidatively polymerized samples of ITX are presented in Figures 68 and 69. Each sequence of photographs shows the initial transition from 


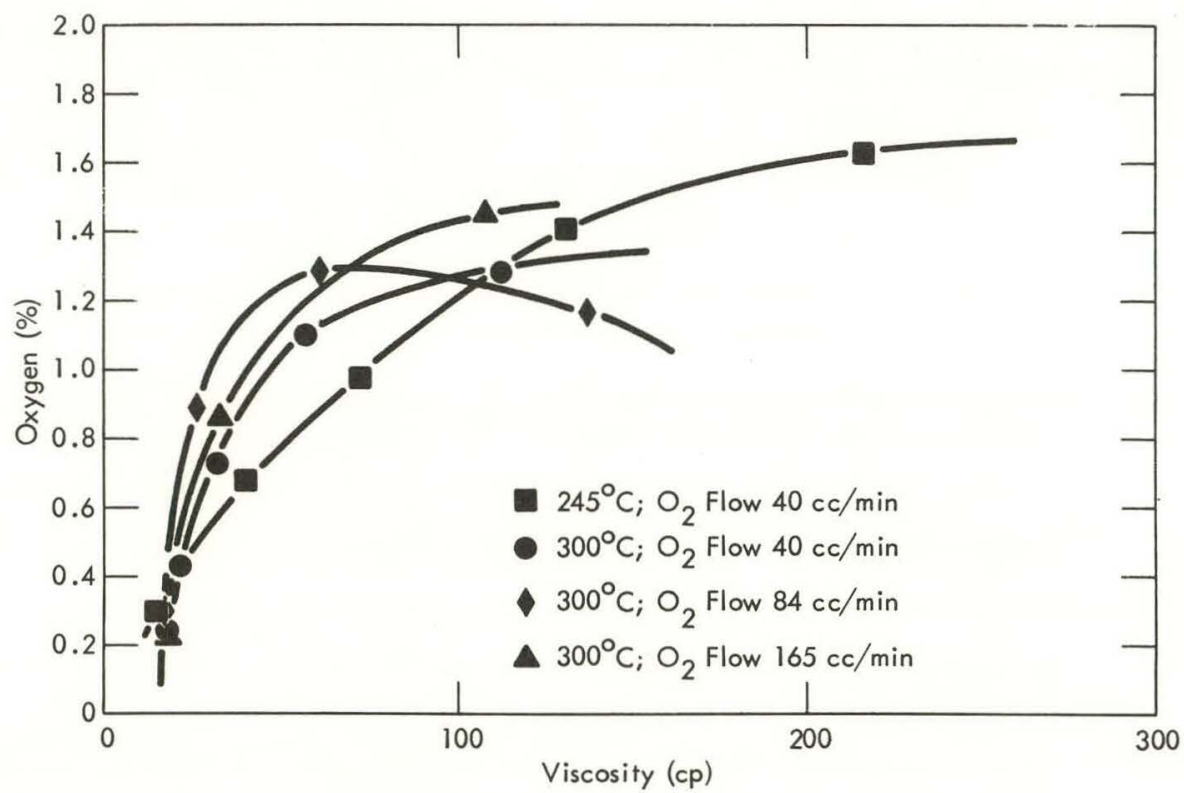

Figure 62. CORRELATIONS BETWEEN OXYGEN CONTENTS AND VISCOSITIES (MEAS URED AT THE HEAT-TREATMENT TEMPERATURE) OF ISOTRUXENE SAMPLES ON HEAT TREATMENT IN THE PRESENCE OF OXYGEN GAS.

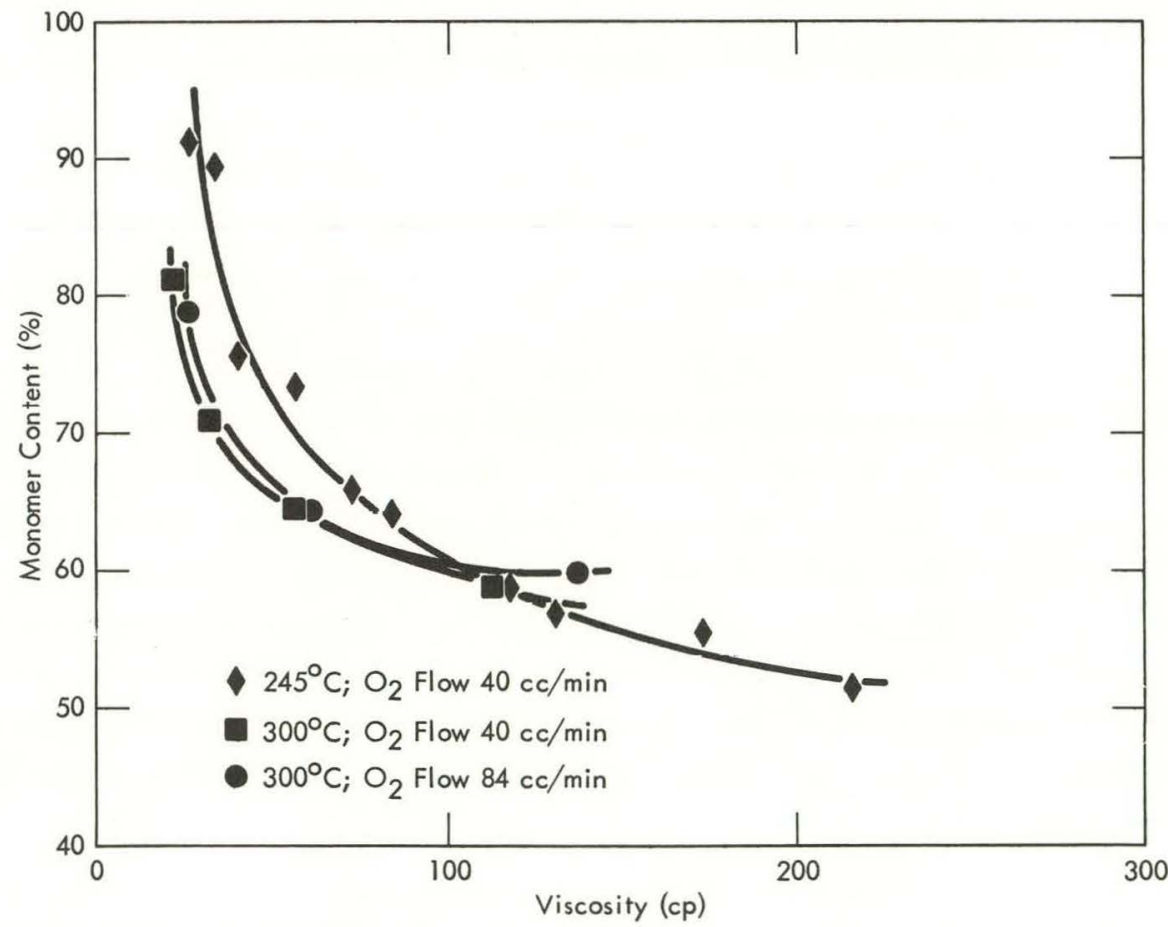

Figure 63. CORRELATIONS BETWEEN THE MONOMER CONTENTS AND VISCOSITIES (MEASURED AT THE HEAT-TREATMENT TEMPERATURE) OF ISOTRUXENE SAMPLES ON HEAT TREATMENT IN THE PRESENCE OF OXYGEN GAS. 


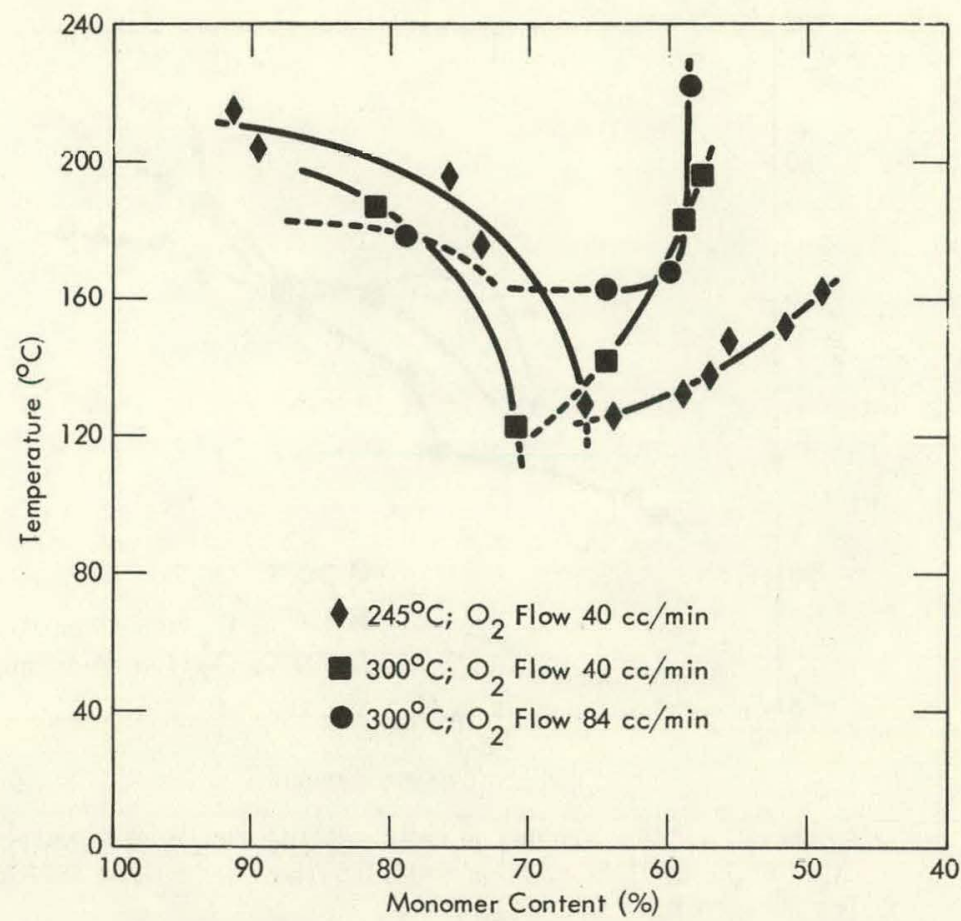

Figure 64. CORRELATIONS BETWEEN FUSION TEMPERATURES (UPPER LIMIT OF RANGE) AND MONOMER CONTENTS OF ISOTRUXENE SAMPLES ON HEAT TREATMENT IN THE PRESENCE OF OXYGEN GAS.

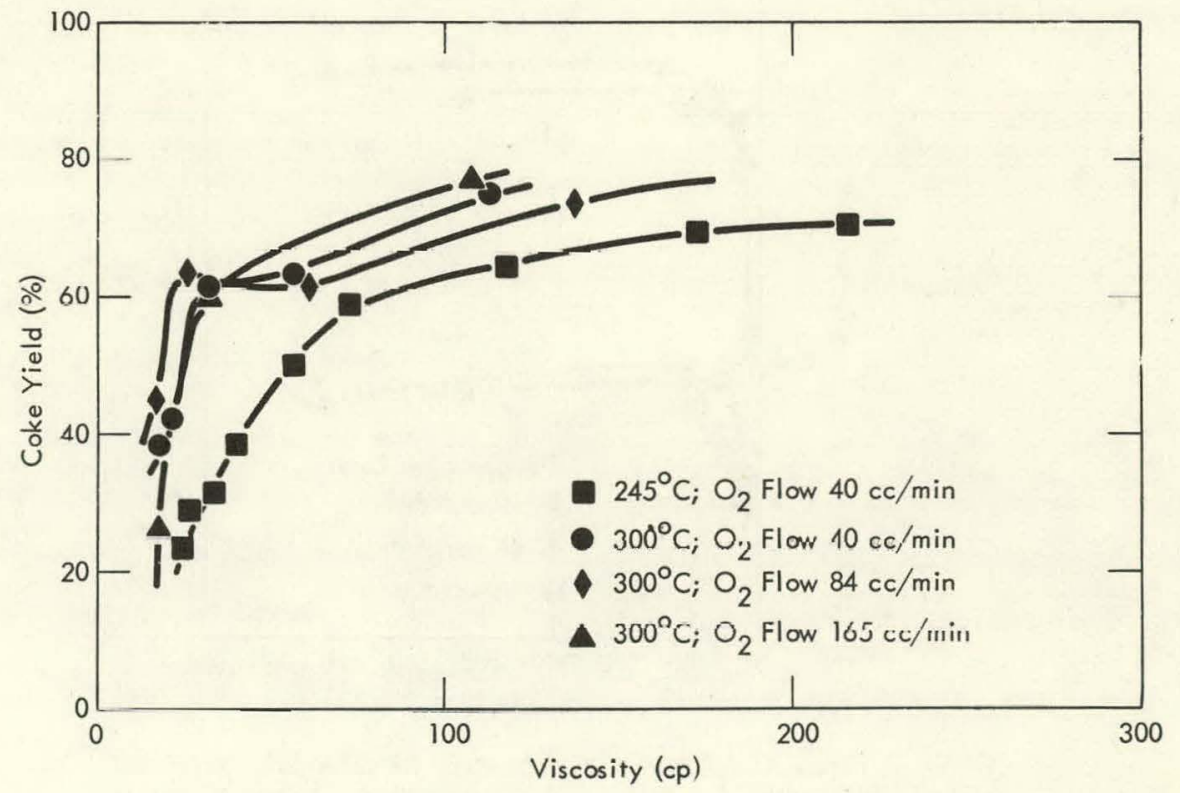

Figure 65. CORRELATIONS BETWEEN COKE YIELDS AND VISCOSITIES (MEASURED AT THE HEAT-TREATMENT TEMPERATURE) OF ISOTRUXENE SAMPLES THAT WERE HEAT TREATED IN THE PRESENCE OF OXYGEN GAS. 


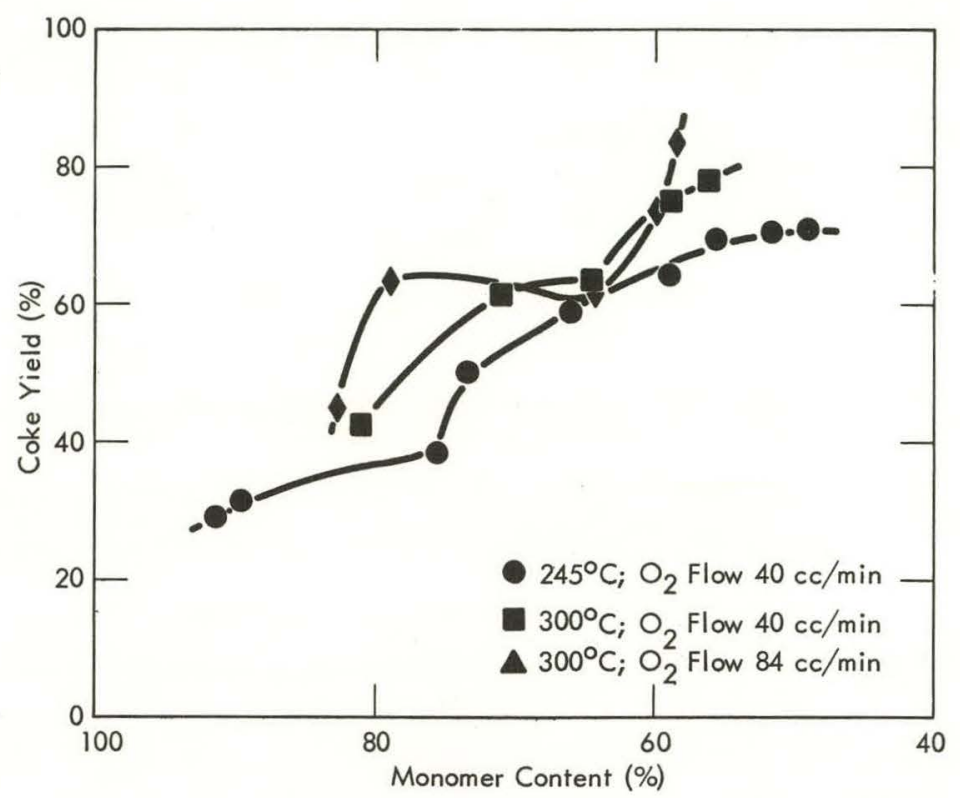

Figure 66. CORRELATIONS BETWEEN COKE YIELDS AND MONOMER CONTENTS OF ISOTRUXENE SAMPLES THAT WERE HEAT TREATED IN THE PRESENCE OF OXYGEN GAS.

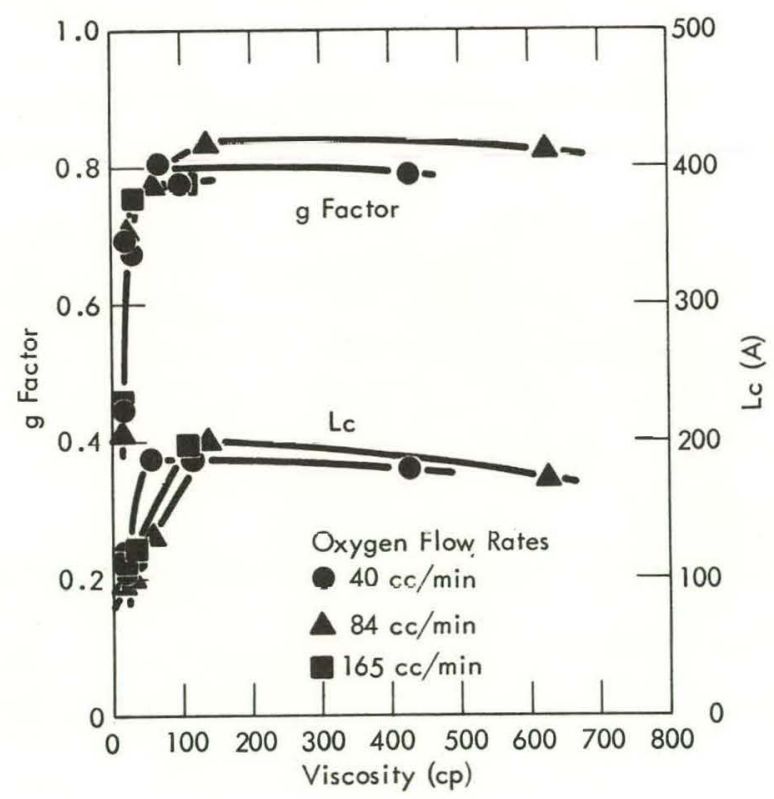

Figure 67. GRAPHITICITY AND CRYSTALLITE SIZE OF CARBON SAMPLES (AFTER $2,800^{\circ} \mathrm{C}$ ) DERIVED FROM ISOTRUXENE AS FUNCTIONS OF THE PRECURSOR VISCOSITY (AT $300^{\circ} \mathrm{C}$ ) ON HEATING AT $300^{\circ} \mathrm{C}$ IN THE PRESENCE OF OXYGEN GAS. 

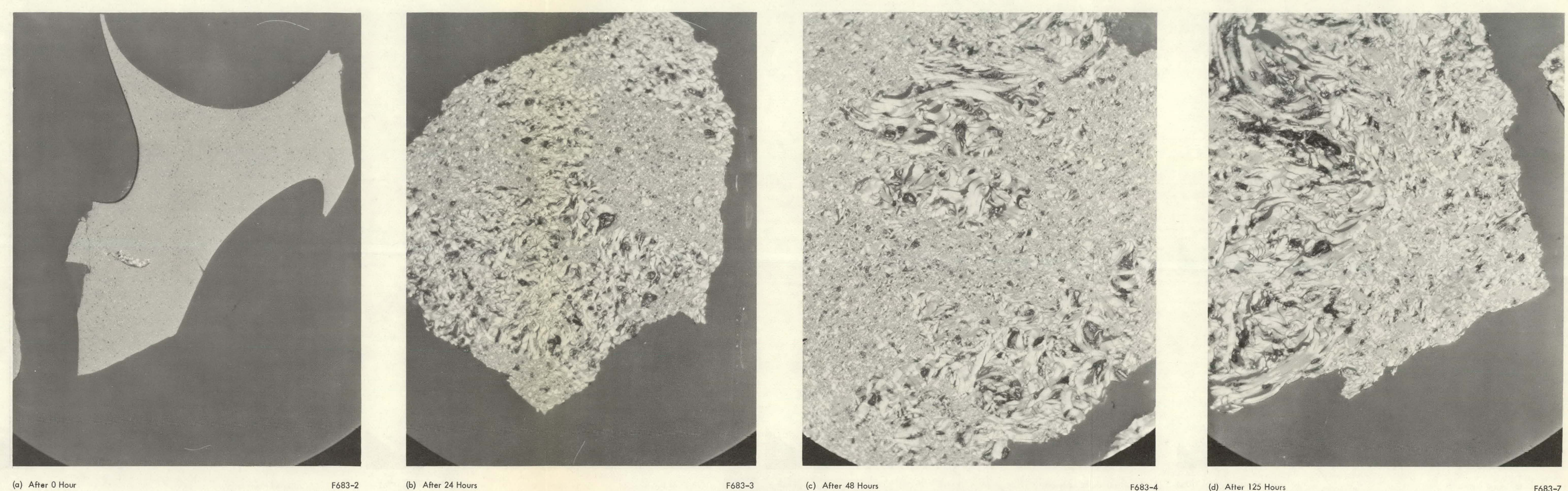

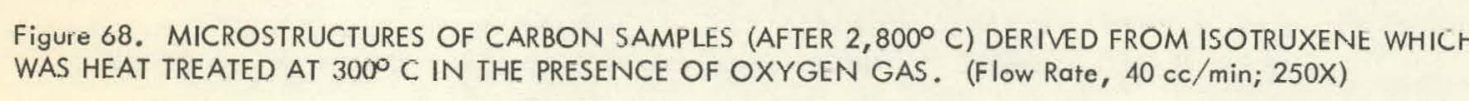



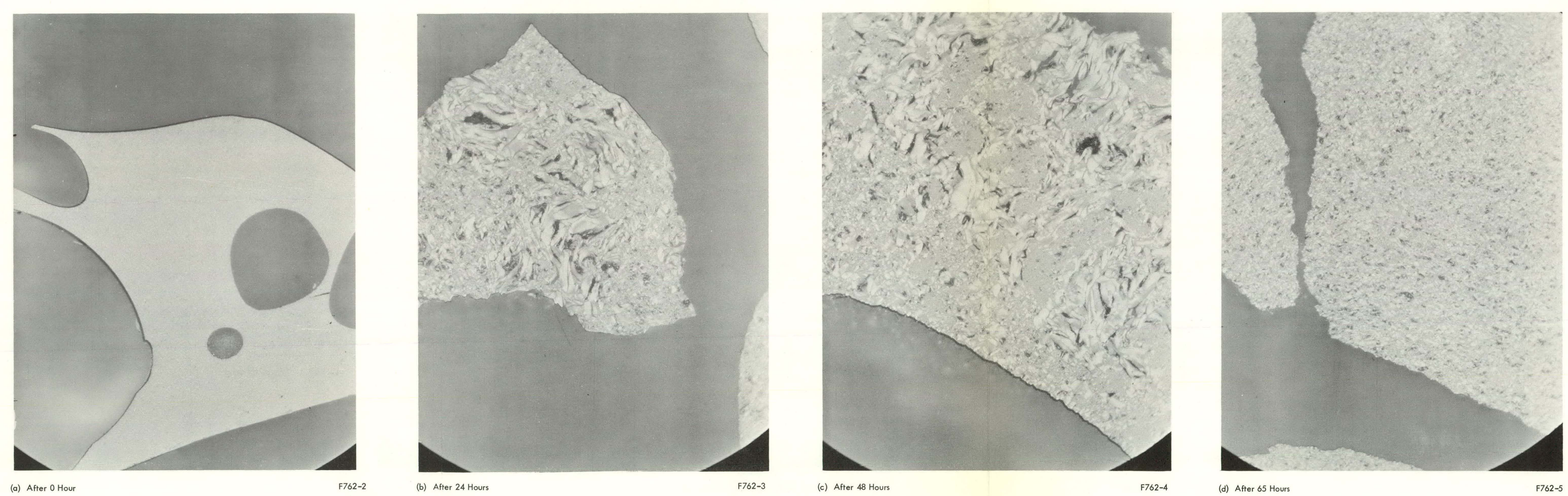

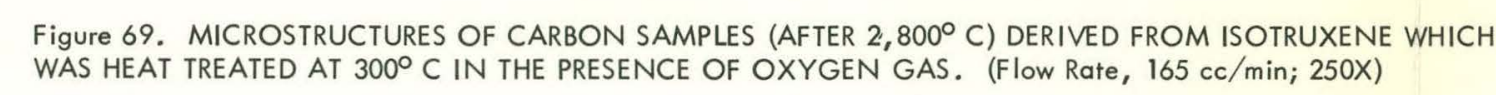


a fine-grain texture of low crystallinity to a coarse-grain, crystalline carbon. This transition corresponds to the significant changes that were observed in other properties during the early stages of heating. On extended heating, the microstructures reflect a slow change back to a fine-grain, crystalline carbon. This latter change was quite apparent when an oxygen flow rate of $165 \mathrm{cc} / \mathrm{min}$ was used (Figure 69).

Properties of Carbon Derived from Blends of Air-Cured and Uncured Isotruxene - Another attempt to control the properties of ITX-derived carbon consisted of blending, in varying proportions, samples of uncured and aircured ITX. The latter were obtained by heating ITX for 30 hours at $300^{\circ} \mathrm{C}$ with oxygen gas (flow rate, $165 \mathrm{cc} / \mathrm{min}$ ) bubbling through the molten material. Samples of air-cured and uncured ITX were dry blended and carbonized. Data obtained for these samples are listed in Table 24. The expected increase in coke yields with increasing content of air-cured ITX is depicted in Figure 70. Of greater interest were the changes in the carbon properties with composition, and the possibility of using this approach to control the carbon properties. Data on the carbons are included in Table 24. Changes in the graphitic properties with increasing content of air-cured ITX is indicated by the graph of Figure 71. These data show a gradual, near-linear increase in g-factor values with increasing content of air-cured ITX. However, crystallite-size $\left(L_{c}\right)$ values were constant at approximately $100 \mathrm{~A}$ except for the sample corresponding to 100 percent air-cured ITX, which increased to approximately 140 A.

Table 24

PROPERTIES OF CARBON DERIVED FROM BLENDS OF AIR-CURED AND UNCURED ISOTRUXENE

\begin{tabular}{|c|c|c|c|c|c|}
\hline \multirow[b]{2}{*}{$\begin{array}{c}\text { Sample } \\
\text { Number }(1)\end{array}$} & \multirow{2}{*}{$\begin{array}{c}\text { Air-Cured } \\
\text { ITX } \\
\text { Content } \\
\text { (\%) }\end{array}$} & \multirow{2}{*}{$\begin{array}{c}\text { Coke Yield } \\
\text { After } \\
1,000^{\circ} \mathrm{C} \\
(\%)\end{array}$} & \multicolumn{3}{|c|}{ Properties After $2,800^{\circ} \mathrm{C}$} \\
\hline & & & $\begin{array}{l}\text { donu } \\
\text { (A) }\end{array}$ & $\mathrm{g}$ factor & $\begin{array}{l}L_{C} \\
(A) \\
\end{array}$ \\
\hline B & 0 & 41 & 1.7001 & 0.471 & 97 \\
\hline c & 25 & 52 & 1.6943 & 0.600 & 98 \\
\hline D & 50 & 58 & 1.6917 & 0.671 & 98 \\
\hline E & 75 & 59 & 1.6897 & 0.718 & 98 \\
\hline $\mathrm{F}$ & 100 & 65 & 1.6862 & 0.800 & 137 \\
\hline
\end{tabular}

(1) Air-cured ITX obfained by heating ITX for 30 hours at $300^{\circ} \mathrm{C}$ with oxygen gas (flow rate, $165 \mathrm{cc} / \mathrm{min}$ ) bubbling through the molten sample. Air-cured and uncured ITX were dry blended prior to carbonization.

Carbons derived from these blends of ITX were relatively homogeneous, as indicated by the microstructures in Figure 72 which show a transition in grain 


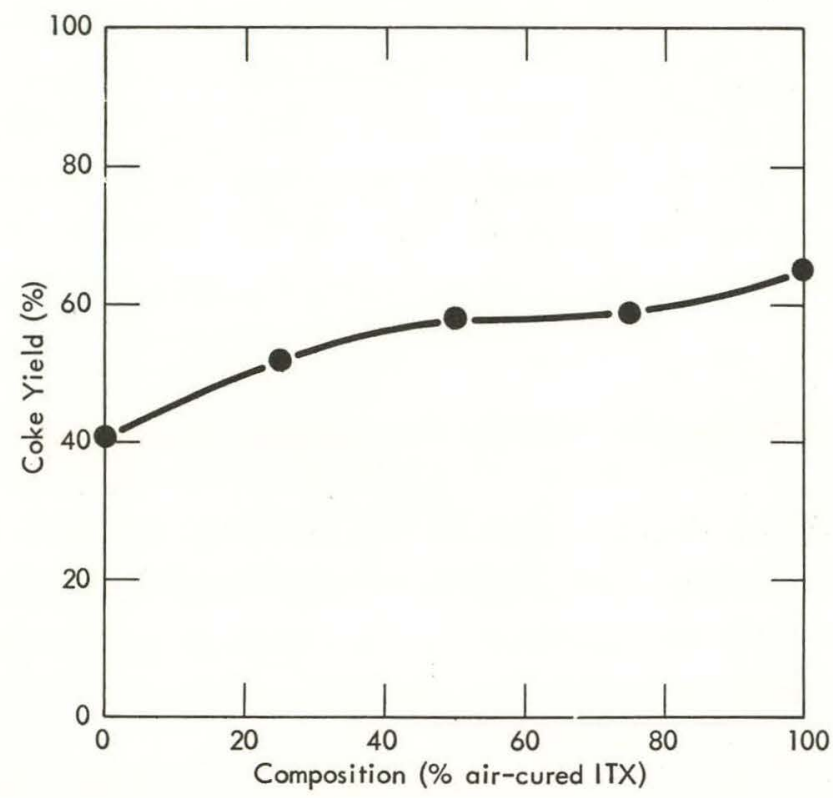

Figure 70. COKE YIELDS (AFTER $1,000^{\circ} \mathrm{C}$ ) OF BLENDS OF UNCURED AND AIR-CURED ISOTRUXENE AS A FUNCTION OF THE COMPOSITION.

texture with precursor composition. Collectively, these data suggest that such an approach can be used to control the properties of ITX-derived carbon within the limits dictated by the two precursor components.

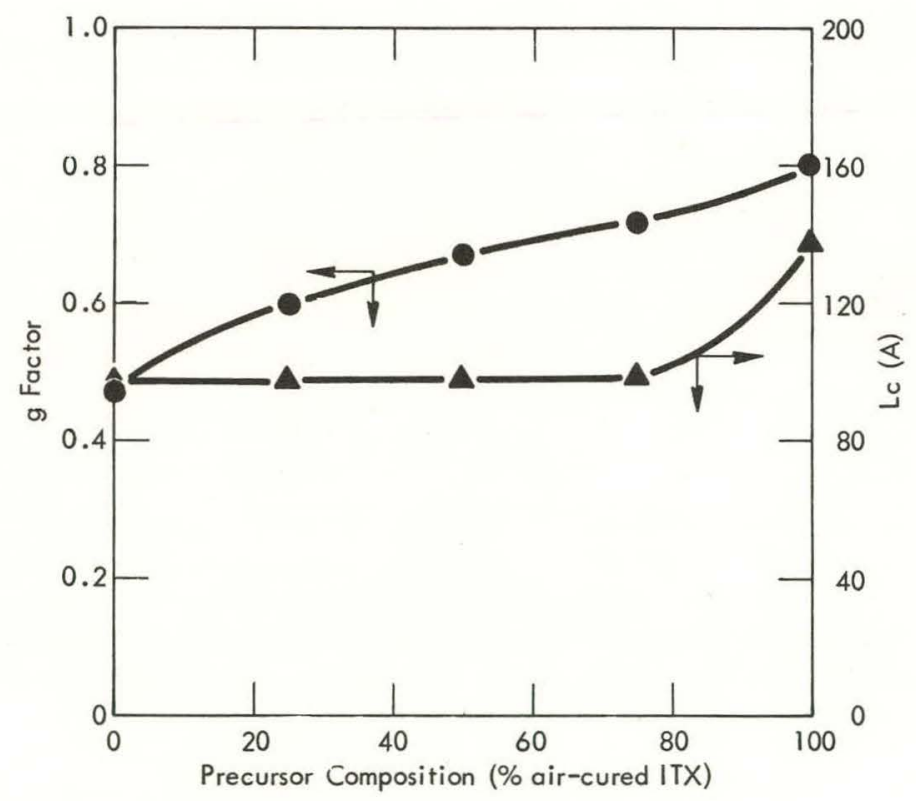

Figure 71. GRAPHITICITY AND CRYSTALLITE SIZE (AFTER $2800^{\circ} \mathrm{C}$ ) OF CARBON SAMPLES DERIVED FROM MIXTURES OF AIR-CURED AND UNCURED ISOTRUXENE. 

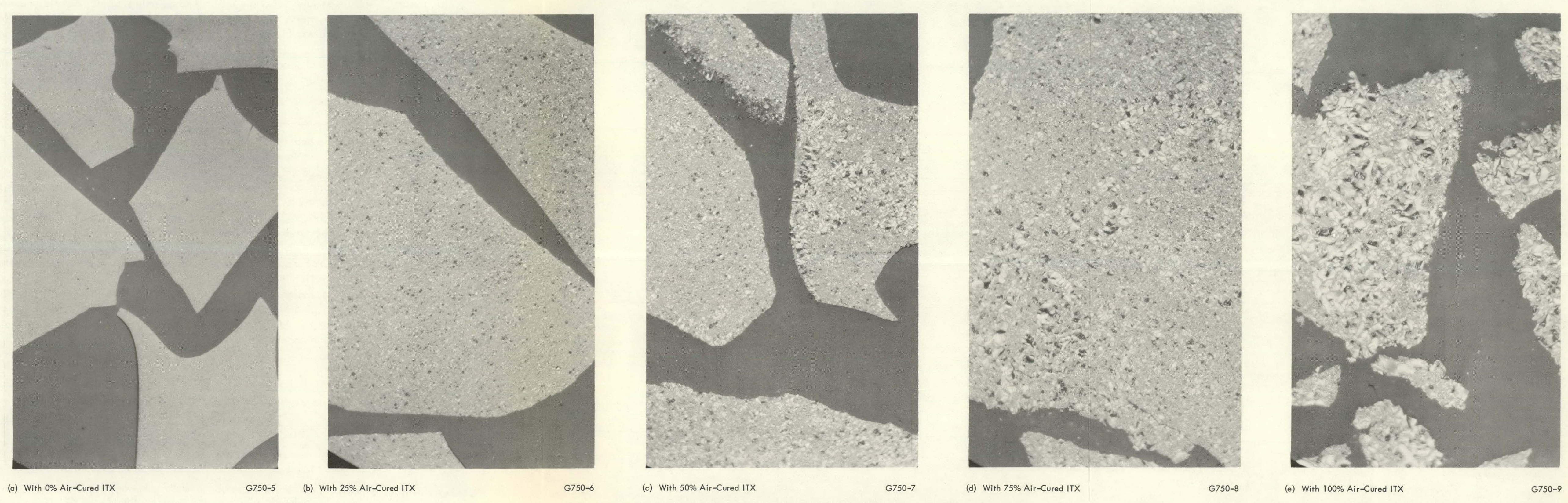

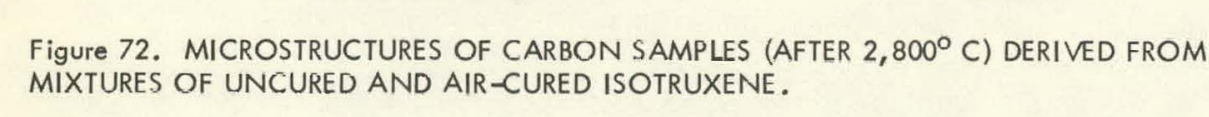


Properties of Carbon Derived from Isotruxene-Sulfur Mixtures - Sulfur-ITX mixtures were evaluated in order to compare the effects of sulfur on the carbon properties with those attributed to oxidative polymerization. Sulfur and ITX were dry blended as powders and the powders subsequently carbonized. In theory, sulfur should function as a crosslinking agent, and its presence should alter the polymerization mechanisms and thus the carbon properties. Since high temperatures $\left(1,600-1,800^{\circ} \mathrm{C}\right)$ are required to remove the last traces of sulfur from carbon, it is undesirable for certain applications. However, many natural sources of carbon contain sulfur, and uncontrolled variations in the sulfur content of raw materials will result in variable carbon properties.

Properties of the carbons derived from these sulfur-ITX mixtures are reported in Table 25. As can be seen in Figure 73, coke yields increased with an increasing sulfur content, and appeared to approach a maximum of $75-80$ percent for precursors containing up to 15 percent powdered sulfur. Graphitic properties of the carbons, as expressed in terms of X-ray diffraction data, pass through a maximum as the sulfur content in the precursor increases, and are noted to decrease at powdered sulfur concentrations greater than 6- 8 percent. Figure 74, which expresses g-factor and crystallite-size values as functions of the precursor composition, shows these maxima. Thus sulfur, as did oxygen, tends to increase both the coke yield and graphiticity of the ITX-derived carbons. High concentrations of sulfur appear to have much the same effect as prolonged oxidative cures in that graphiticity begins to decrease. On prolonged hent treatment, these effocts would probably ulsu be noted at lower sulfur concentrations.

Table 25

EFFECT OF SULFUR ON THE PROPERTIES OF CARBONS DERIVED FROM ISOTRUXENE

\begin{tabular}{|c|c|c|c|c|c|}
\hline \multirow[b]{2}{*}{ Sample(1) } & \multirow{2}{*}{$\begin{array}{c}\text { Sulfur } \\
\text { Content in } \\
\text { Precursor } \\
(\%)\end{array}$} & \multirow{2}{*}{$\begin{array}{c}\text { Coke Yield } \\
\text { after } \\
1, \cap \cap 0^{\circ} \mathrm{C} \\
(\%)\end{array}$} & \multicolumn{3}{|c|}{$\begin{array}{c}\text { Carbon Properties } \\
\text { After } 2,800^{\circ} \mathrm{C}\end{array}$} \\
\hline & & & $\begin{array}{l}\mathrm{d} 004 \\
(\mathrm{~A})\end{array}$ & $g$ factor & $\begin{array}{l}L_{C} \\
(A)\end{array}$ \\
\hline c & 0 & 58 & 1.7022 & 0.424 & 104 \\
\hline D & 1.0 & 57 & 1.6958 & 0.565 & 112 \\
\hline$E$ & 3.0 & 61 & 1.6903 & 0.694 & 104 \\
\hline $\mathrm{F}$ & 5.0 & 64 & 1.6848 & 0.824 & 227 \\
\hline G & 10.0 & 73 & 1.6848 & 0.824 & 208 \\
\hline $\mathrm{H}$ & 15.0 & 76 & 1.6917 & 0.671 & 101 \\
\hline
\end{tabular}

(1) Isotruxene and sulfur were dry blended as powders prior to carbonization; sample size was 30 grams. 


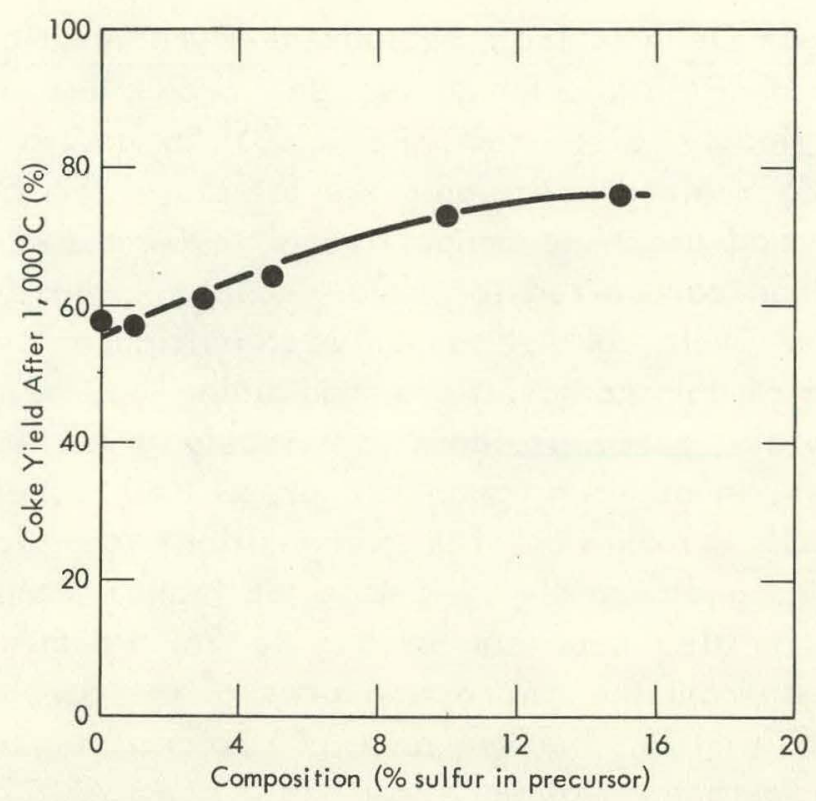

Figure 73. COKE YIELD (AFTER 1,000 C) OF ISOTRUXENE SULFUR MIXTURES AS A FUNCTION OF THE PRECURSOR COMPOSITION.

Microstructures of the carbon samples are seen in Figure 75. The transitions apparent from the microstructures coincide with other changes denoting maxima in the graphitic properties.

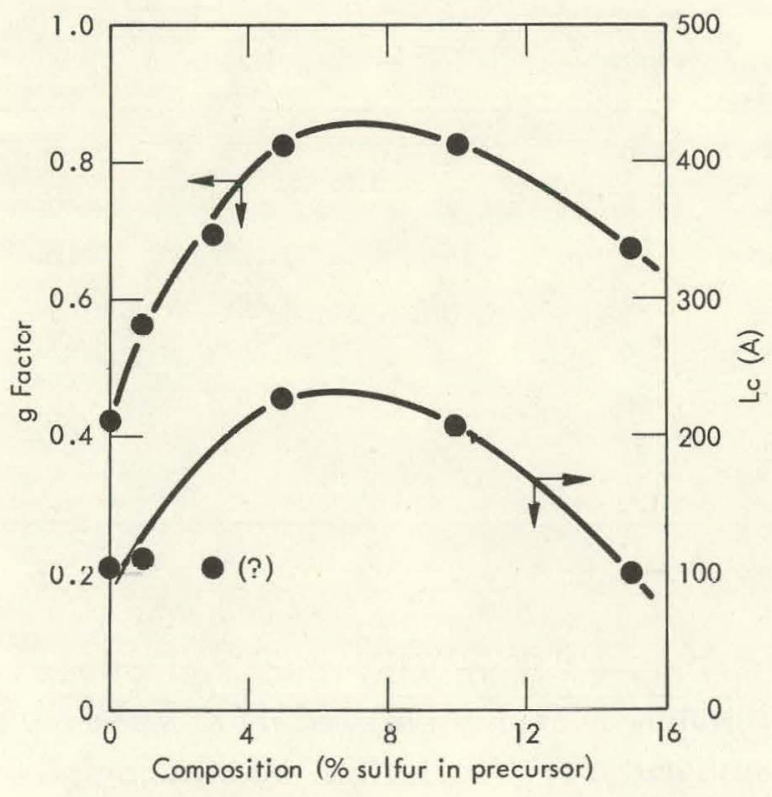

Figure 74. GRAPHITICITY AND CRYSTALLITE SIZE OF CARBON SAMPLES (AFTER $2,800^{\circ} \mathrm{C}$ ) DERIVED FROM ISOTRIIXFNF-SULFUR MIXTURES AS FUNCTIONS OF THE PRECURSOR COMPOSITION. 
Properties of Carbon Derived from Isotruxene-Pyromellitic Dianhydride Mixtures - The effect of PMDA coke yields and properties of carbon from CAI and TX was previously discussed (Page 50). In addition, mixtures of ITX and PMDA were carbonized to evaluate the effects of this benzyne precursor on the coke yields and graphitic properties of ITX-derived carbons. Mixtures were dry blended and carbonized to 1,000 $\mathrm{C}$. Data obtained for these samples are summarized in Table 26. As can be seen in Figure 76, coke-yield values describe a maximum for compositions containing approximately 35 percent PMDA, which closely parallels data previously given for CAI-PMDA and TX-PMDA mixtures. In addition, graphitic properties, as expressed in terms of $g$ factors, reach a maximum for compositions containing approximately 20 percent PMDA, and rapidly decrease at higher PMDA concentrations. This relationship is also apparent in Figure 76. Paralleling these changes are those observed from the microstructures of the carbons, as can be seen in Figure 77. Transitions in the sequence of photomicrographs are in support of changes in the g-factor values shown in Figure 76. This initial increase in graphiticity for Iow PMDA concentrations and the subsequent decrease observed for higher concentrations affords another method of controlling the properties of carbon derived from ITX.

Table 26

PROPERTIES OF CARBON DERIVED FROM ISOTRUXENEPYROMELLITIC DIANHHYDRIDE MIXTURES

\begin{tabular}{cccccc}
\hline $\begin{array}{c}\text { Batch } \\
\text { Number }\end{array}$ & $\begin{array}{c}\text { PMDA } \\
\begin{array}{c}\text { Content } \\
(\%)\end{array}\end{array}$ & $\begin{array}{c}\text { Coke Yield } \\
\text { After } \\
1,000^{\circ} \mathrm{C} \\
(\%)\end{array}$ & $\begin{array}{c}\text { Carbon Properties After } 2,800^{\circ} \mathrm{C} \\
\text { d004 } \\
(\mathrm{A})\end{array}$ & $\mathrm{g}$ factor & $\begin{array}{c}\mathrm{L}_{\mathrm{C}} \\
(\mathrm{A})\end{array}$ \\
\hline $1-91-70 \mathrm{~A}$ & 0 & 49 & 1.6986 & 0.506 & 116 \\
$1-91-70 \mathrm{~B}$ & 5 & 51 & 1.6897 & 0.718 & $<100$ \\
$1-91-70 \mathrm{C}$ & 10 & 57 & 1.6822 & 0.894 & 297 \\
$1-91-70 \mathrm{D}$ & 20 & 61 & 1.6817 & 0.906 & 457 \\
$1-92-70 \mathrm{~A}$ & 30 & 66 & 1.6848 & 0.824 & 161 \\
$1-92-70 \mathrm{~B}$ & 50 & 57 & - & - & - \\
$1-92-70 \mathrm{C}$ & 75 & 35 & - & - & - \\
$1-92-70 \mathrm{D}$ & 100 & 4 & - & - & - \\
\hline
\end{tabular}

Properties of Carbon Derived from Vinylated Derivatives of Isotruxene - Carbon properties of vinylated derivatives of ITX were evaluated as a function of the vinylation temperature. Vinylation was accomplished by heating ITX in an autoclave under acetylene pressure.(8) Samples were subsequently carbonized without additional treatment. Data on these materials are reported in Table 27. As indicated, vinylation produces a low-melting polymer with 

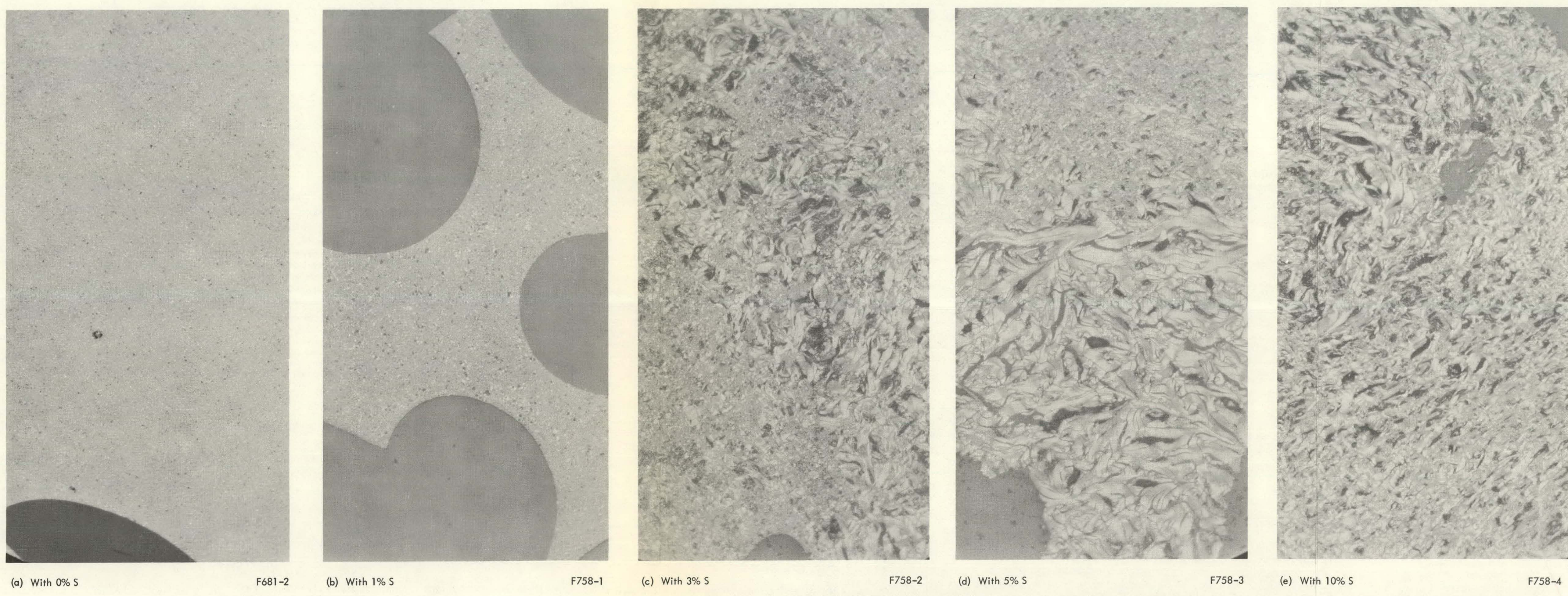

Figur 75. MICROSTRUCTURES OF CARBON SAMPLES (AFTER 2,800 $\mathrm{C}$ ) DERRIVED

F758-4

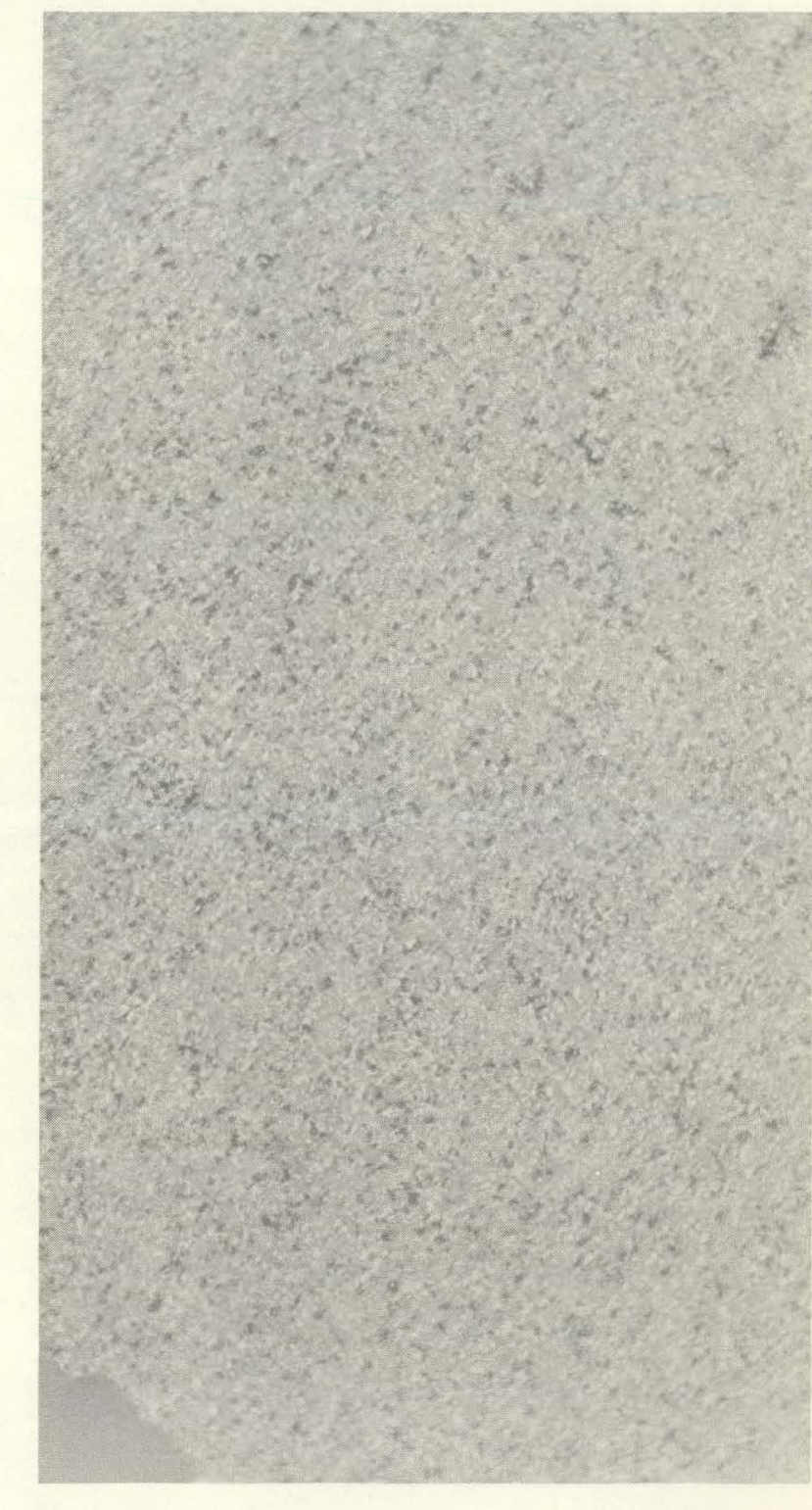

(f) With $15 \%$ 


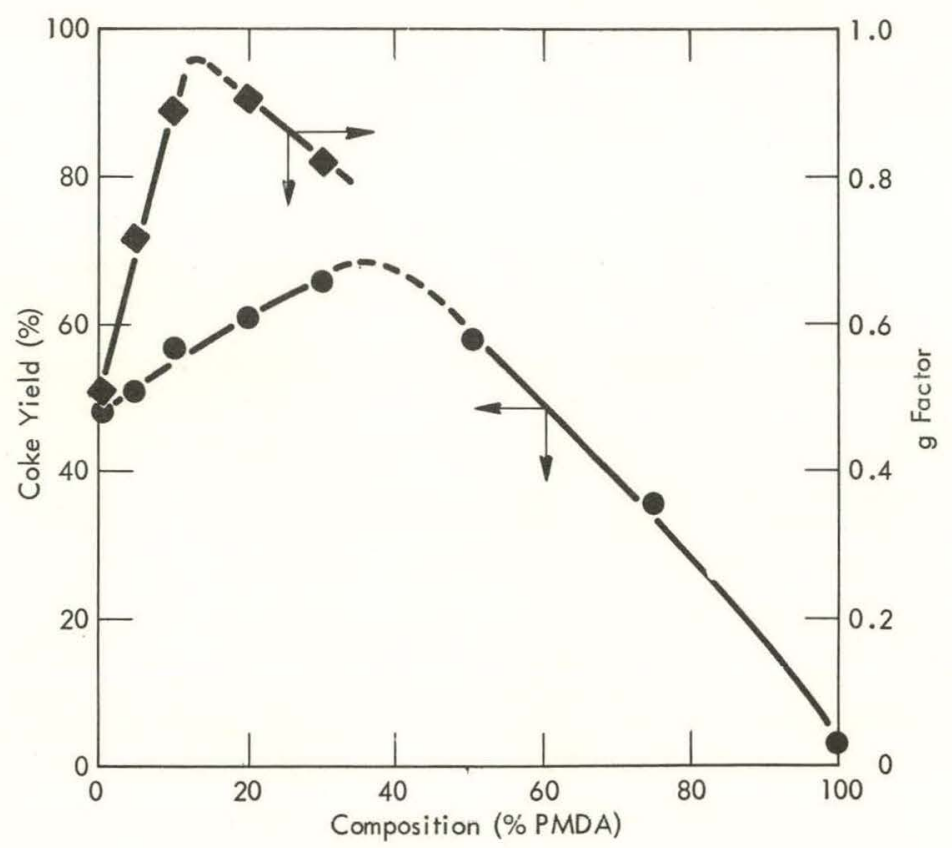

Figure 76. COKE YIELD (AFTER 1,000 C) AND g FACTOR (AFTER $2,800^{\circ} \mathrm{C}$ ) OF CARBON SAMPLES DERIVED FROM MIXTURES OF ISOTRUXENE AND PYROMELLITIC DIANHYDRIDE AS FUNCTIONS OF THE PYROMELLITIC DIANHYDRIDE CONTENT.

coke-yield values that increase with increasing vinylation temperaturea, Vinylation has a very significant effect on the graphitic properties of carbons derived from ITX. This influence is apparent when the X-ray diffraction data in Table 27 are compared with that of the uncured ITX in Table 16. Examination of the microstruetures sliuwil in Figure 78 further emphasizes the effect of vinylation. The texture is that of a large-grain, lamellar carbon

Table 27

PROPERTIES OF CARBON DERIVED FROM VINYLATED DERIVATIVES OF ISOTRUXENE

\begin{tabular}{|c|c|c|c|c|c|c|c|}
\hline \multirow[b]{2}{*}{$\begin{array}{c}\text { Sample } \\
\text { Number }(1)\end{array}$} & \multirow{2}{*}{$\begin{array}{l}\text { Reaction } \\
\text { Temperature } \\
\left({ }^{\circ} \mathrm{C}\right)\end{array}$} & \multirow{2}{*}{$\begin{array}{l}\text { Average } \\
\text { Molecular } \\
\text { Weight }\end{array}$} & \multirow{2}{*}{$\begin{array}{l}\text { Melting } \\
\text { Properties } \\
\left({ }^{\circ} \mathrm{C}\right)\end{array}$} & \multirow{2}{*}{$\begin{array}{c}\text { Coke Yield } \\
\text { After } \\
1,000^{\circ} \mathrm{C} \\
(\%)\end{array}$} & \multicolumn{3}{|c|}{ Properties After $2,800^{\circ} \mathrm{C}$} \\
\hline & & & & & $\begin{array}{c}\text { do04 } \\
\text { (A) }\end{array}$ & $\mathrm{g}$ factor & $\begin{array}{l}L_{c} \\
(A) \\
\end{array}$ \\
\hline $11-07-69(2)$ & 150 & $\begin{array}{l}\text { (a) } 381 \\
\text { (b) } 422\end{array}$ & $\begin{array}{c}215-220 \\
\text { Liquid at } \sim 65\end{array}$ & 33 & 1.6797 & 0.953 & 383 \\
\hline $11-08-69$ & 200 & 418 & $\begin{array}{l}\text { Pliable at } 40, \\
\text { Fluid at } 100\end{array}$ & 42 & 1.6817 & 0.906 & 328 \\
\hline $11-09-69$ & 250 & 173 & $\begin{array}{l}\text { Pliable at } 25, \\
\text { Fluid at } 70\end{array}$ & 48 & 1.6800 & 0.941 & 411 \\
\hline
\end{tabular}

(1) Reactant materials consisted of 34.2 grams isotruxene, 6 grams potassium hydroxide, 2 milliliters water, and 200 milliliters toluene. Reactions were carried out in a one-liter autoclave by initially pressurizing to 250 psi with acetylene gas and heating for five hours at the designated temperature. The autoclave mixture was continuously stirred at $600 \mathrm{rpm}$.

(2) Product from 11-07-69 was a mixture of two materials: (a) unreacted isotruxene; and (b) a polymeric material. 


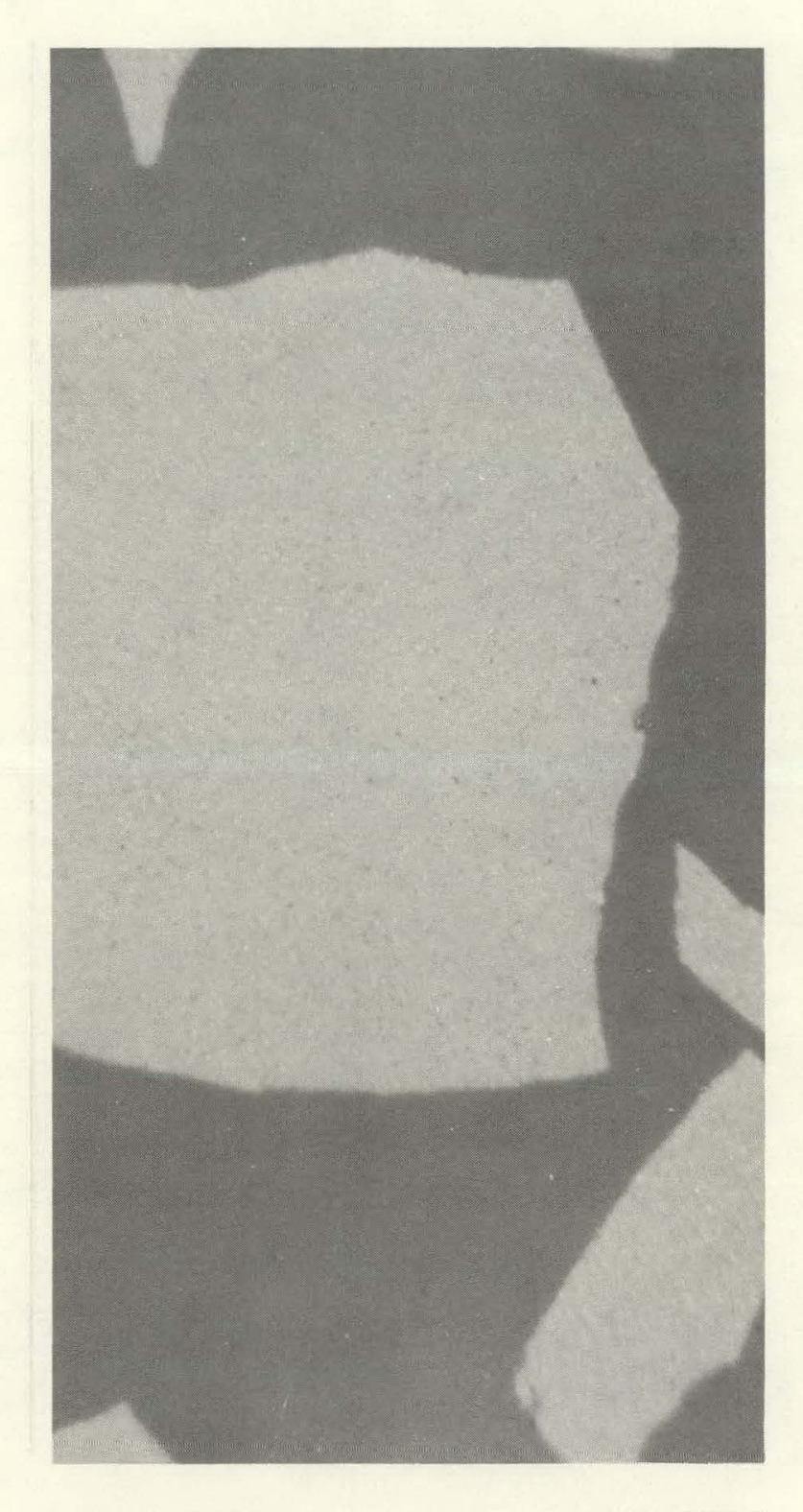

(a) With 0\% PMDA

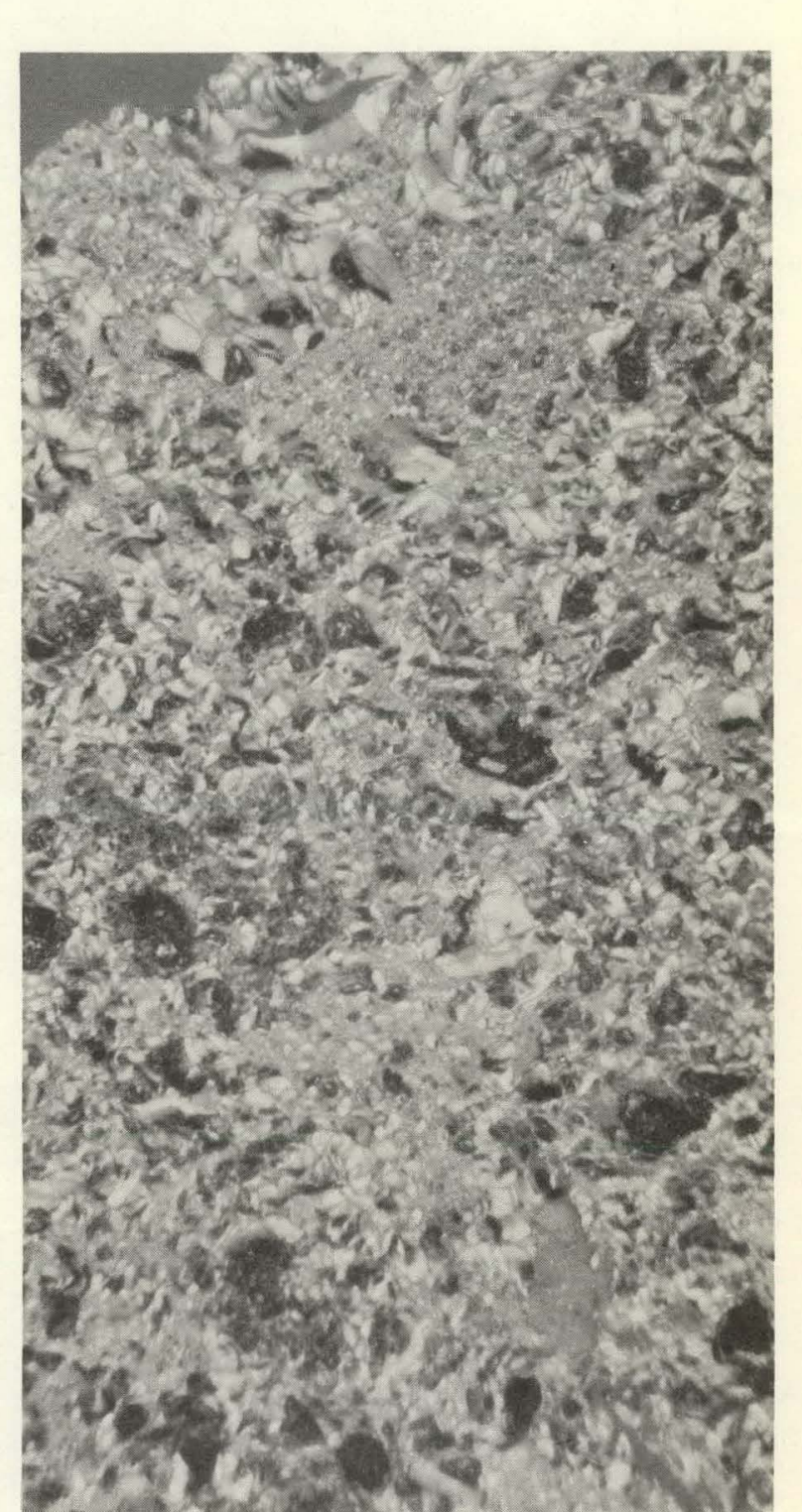

G330-1 $\quad$ (b) With $5 \%$ PMDA

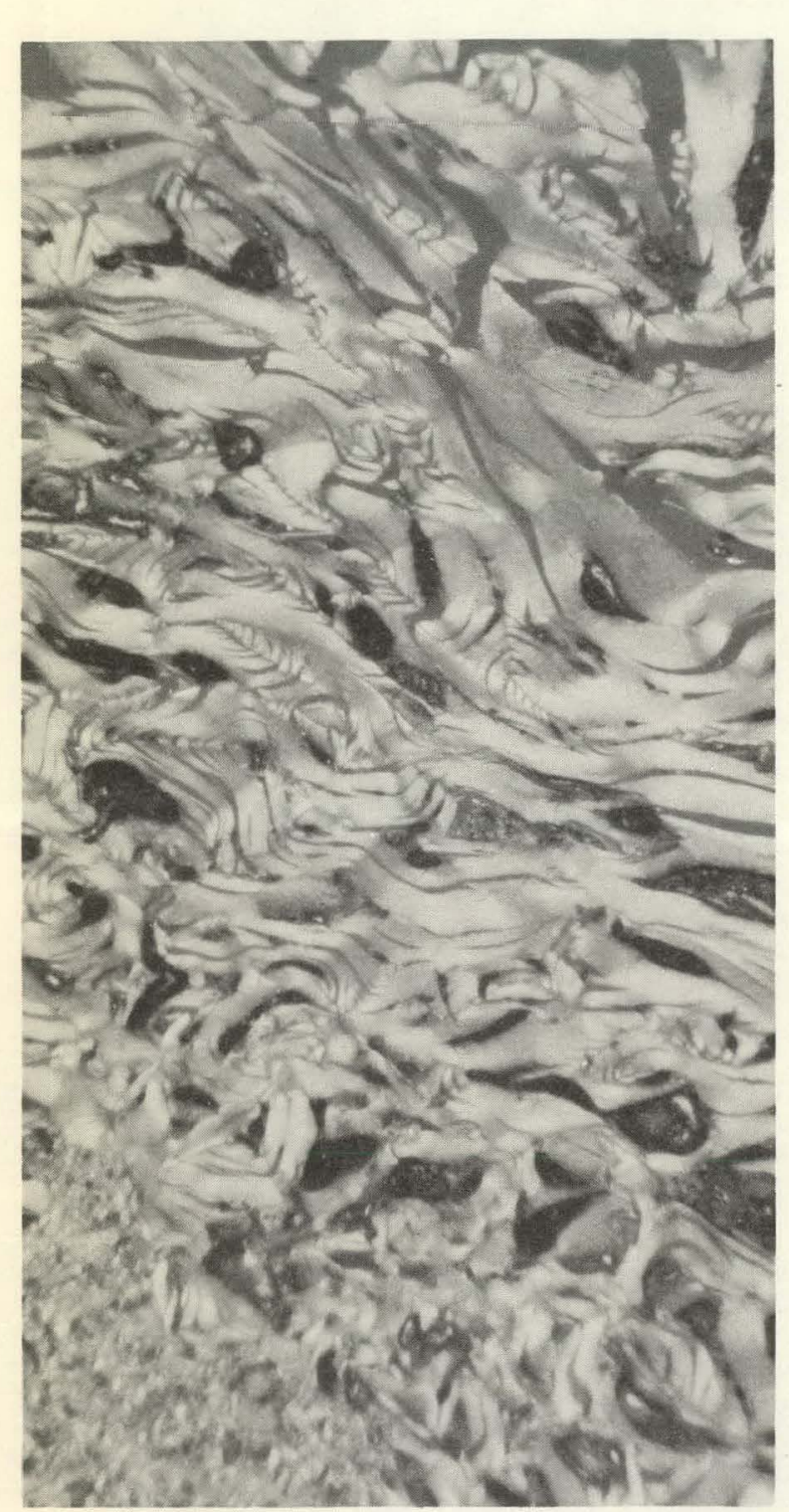

(c) With 10\% PMDA

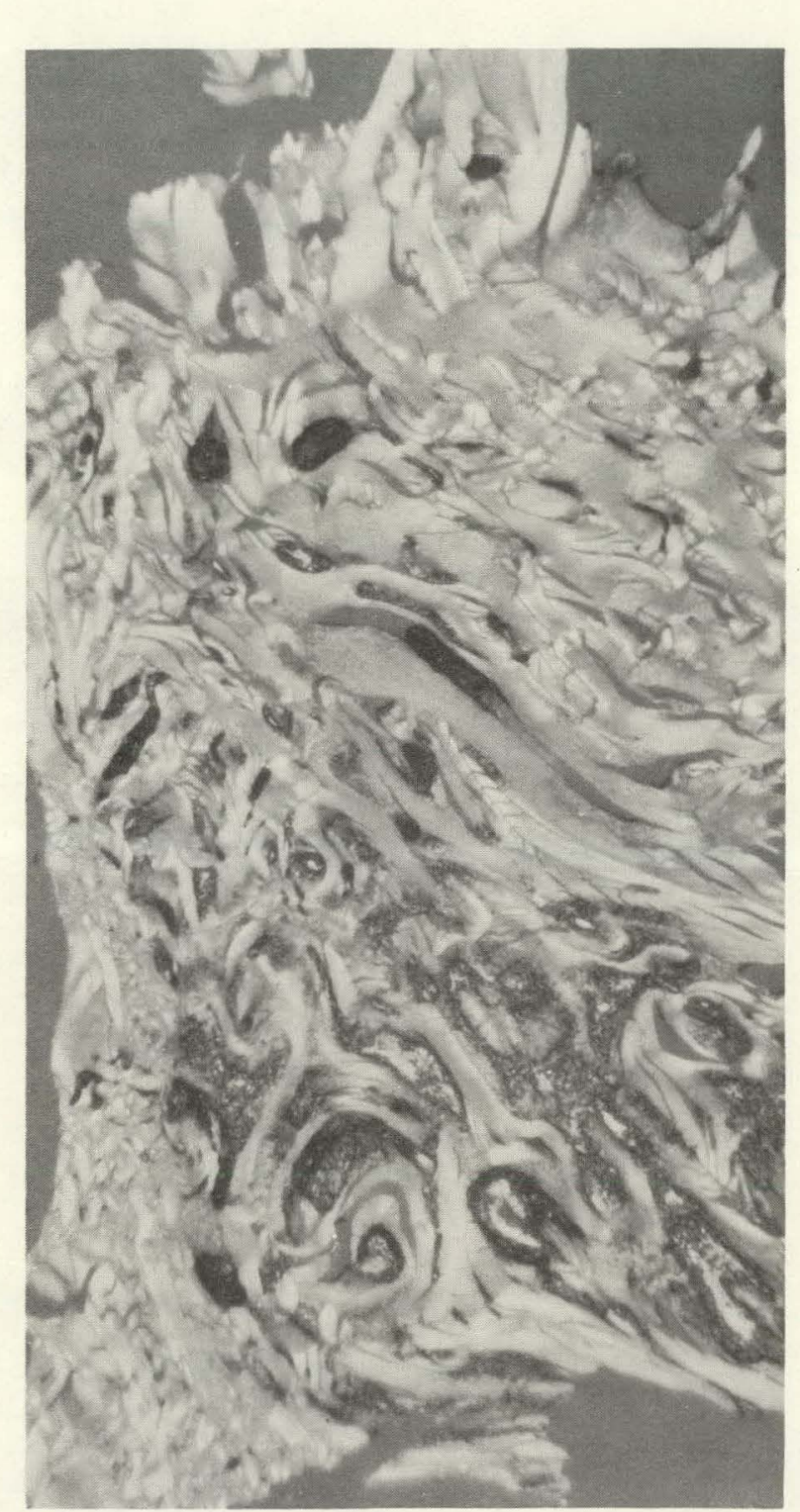

(d) With 20\% PMDA

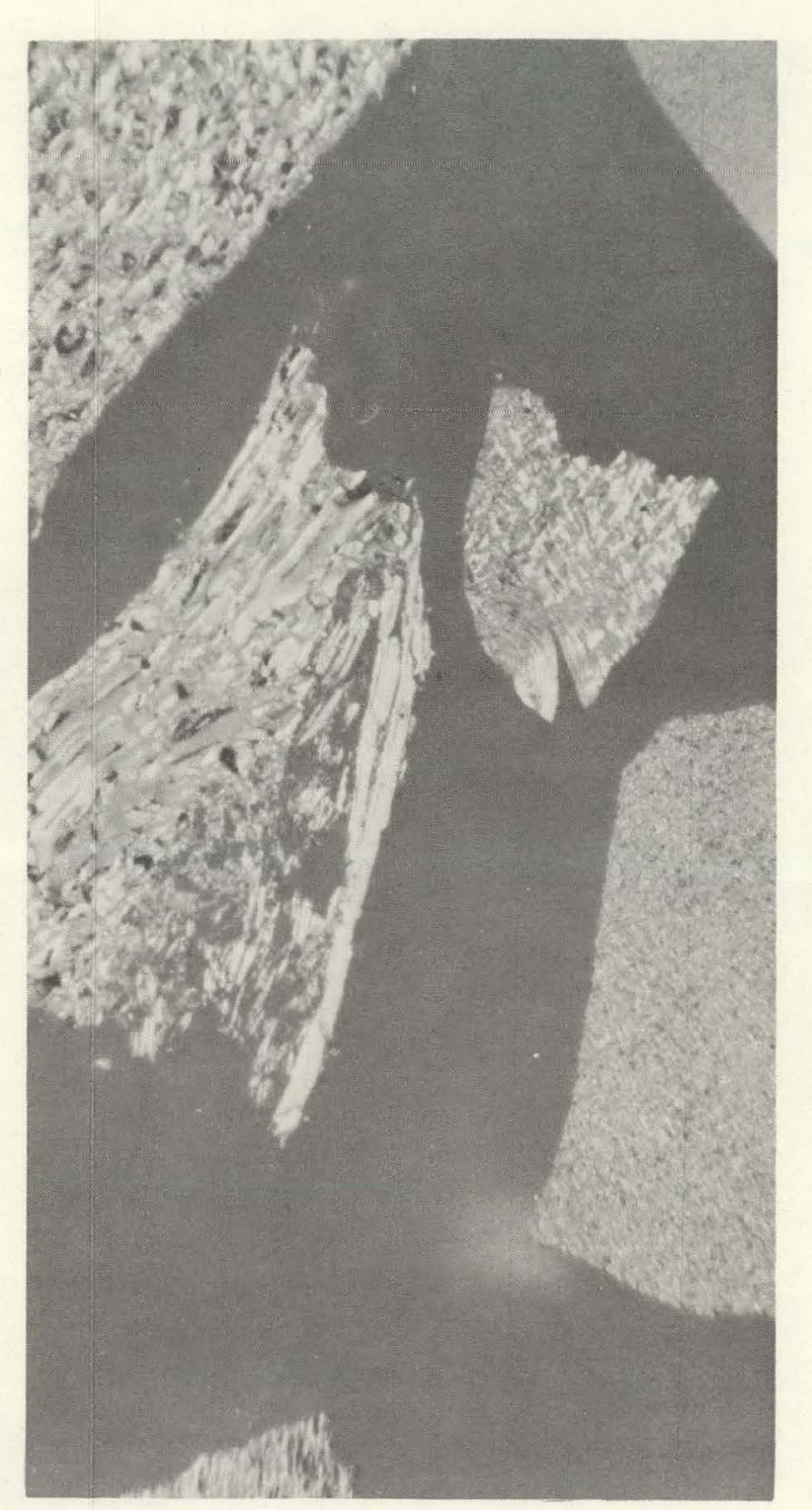

G $330-4 \quad$ (e) With $30 \%$ PMDA

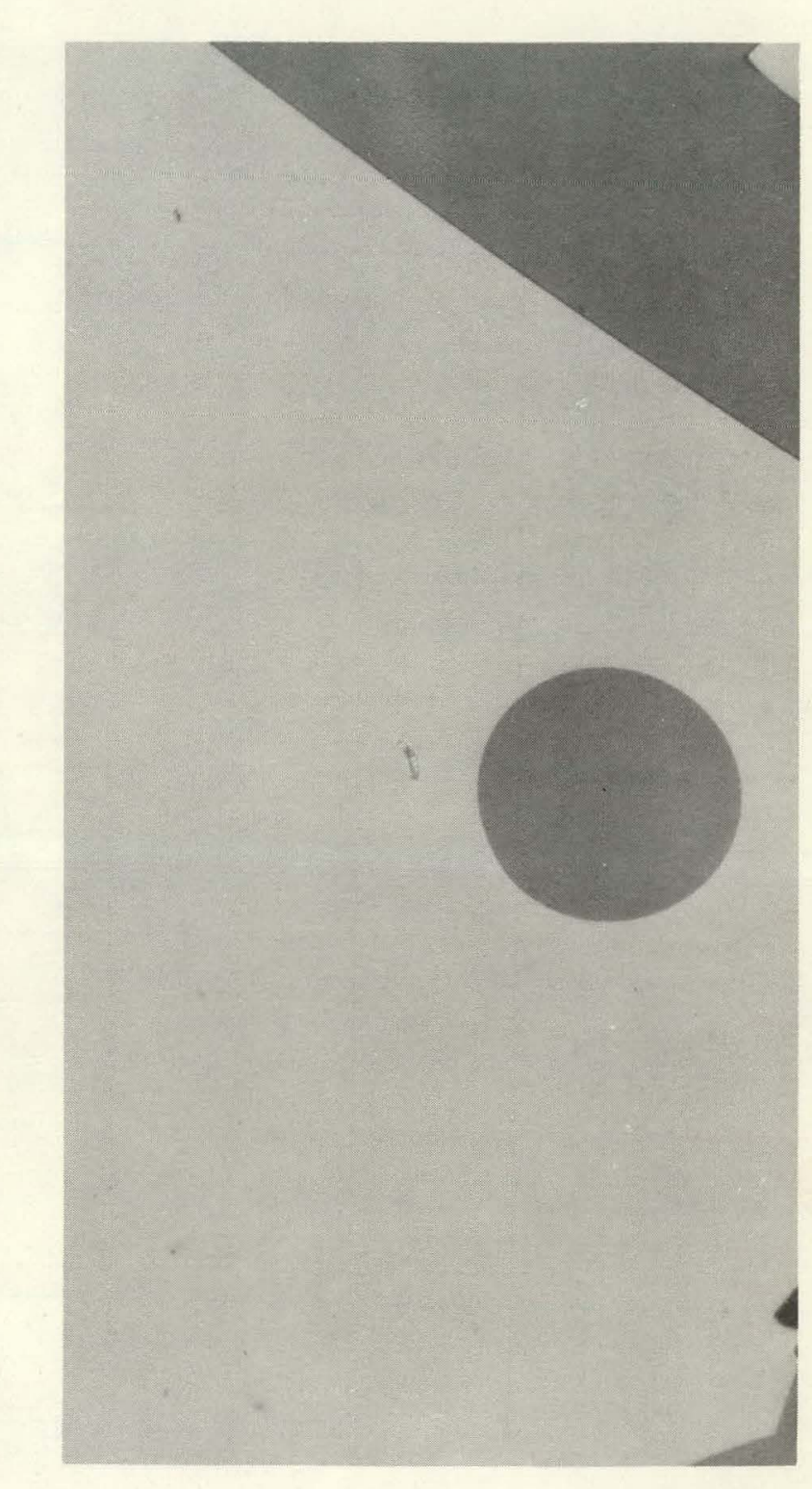

(f) With 50\% PMDA 

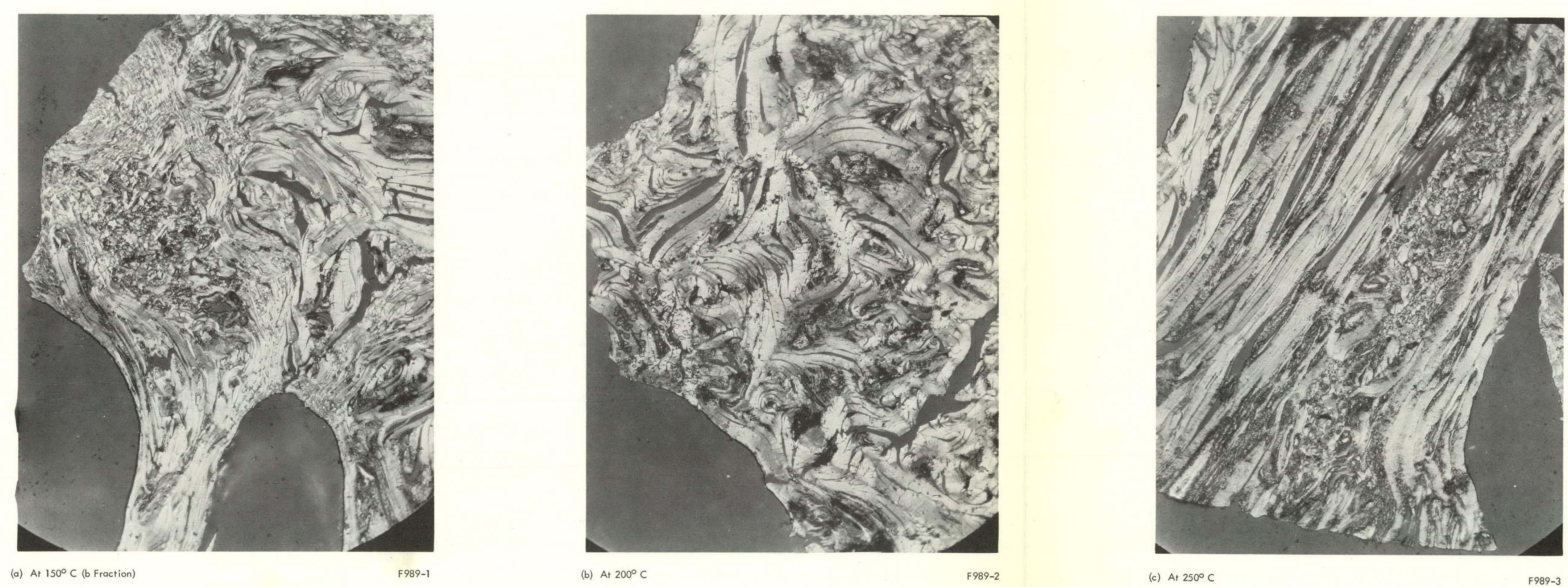

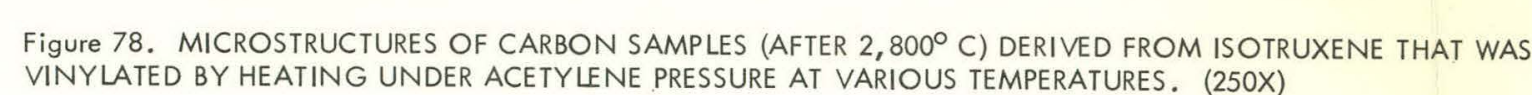


which produces a needle coke similar to that derived from acenaphthylene carbons. These microstructures may be compared with those from the uncured, unreacted ITX in Figure 43. No correlations between carbon properties and vinylation temperatures were apparent.

\section{Truxene-Isotruxene Mixtures}

Properties of Carbon Derived from Truxene-Isotruxene Mixtures - Copolymerization of two carbon precursor materials which individually give rise to different carbon properties was considered as an approach to the controlled modification of derived carbons. Since homogeneity of the derived carbon is essential, certain factors must be considered when choosing materials for copolymerization. In essence, materials chosen should be miscible in the fluid phase and should have polymerization properties (such as conditions of initiation and rates of reaction) that are relatively compatible and which produce polymers that are and remain homogeneous through pyrolysis.

Since truxene and isotruxene yield carbons that are nongraphitic and graphitic, respectively, carbon materials derived from mixtures of these two materials were evaluated. Mixtures of varying compositions were air cured to $250^{\circ} \mathrm{C}$ and were subsequently carbonized to $1,000^{\circ} \mathrm{C}$. As would be expected from the relative coke yields of the two precursor materials, coke-yield data show an increase with increasing truxene content, becoming essentially constant for mixtures containing $>50$ percent truxene. Densities (via helium displacement) were determined after firing at 1,000, 1,600, 2,000,2,400, and 2,800 $\mathrm{C}$. Data obtained for these samples are reported in Table 28. As shown in Figure 79,

Table 28

PROPERTIES OF CARBON DERIVED FROM TRUXENE-ISOTRUXENE MIXTURES

\begin{tabular}{|c|c|c|c|c|c|c|c|c|c|}
\hline \multirow[b]{2}{*}{$\begin{array}{c}\text { Batch } \\
\text { Number }\end{array}$} & \multirow{2}{*}{$\begin{array}{c}\text { Isotruxene } \\
\text { Content }(1) \\
\text { (wt \%) }\end{array}$} & \multirow{2}{*}{\multicolumn{5}{|c|}{ Density $(\mathrm{gm} / \mathrm{cc})$ at Temperature $\left({ }^{\circ} \mathrm{C}\right)$}} & \multirow{2}{*}{$\begin{array}{c}\text { Coke Yield, } \\
\text { Room } \\
\text { Temperature } \\
\text { to } 1,000^{\circ} \mathrm{C} \\
(\%)\end{array}$} & \multicolumn{2}{|c|}{ X-Ray Diffraction Propertles } \\
\hline & & & & & & & & $\begin{array}{c}\mathrm{d} 004 \\
\text { (A) }\end{array}$ & $g$ factor \\
\hline N21 & 100 & 1.79 & 2.13 & 2.14 & 2.19 & 2.17 & 70 & $1.6820\left(2,800^{\circ} \mathrm{C}\right)$ & $0.894\left(2,800^{\circ} \mathrm{C}\right)$ \\
\hline N22 & 75 & 1.77 & 2.02 & 2.19(?) & 2.06 & 2.08 & 82 & $\begin{array}{l}1.6914\left(2,800^{\circ} \mathrm{C}\right) \\
1.6946\left(2,400^{\circ} \mathrm{C}\right)\end{array}$ & $\begin{array}{l}0.671\left(2,800^{\circ} \mathrm{C}\right) \\
0.600\left(2,400^{\circ} \mathrm{C}\right)\end{array}$ \\
\hline N23 & 50 & 1.76 & 1.47 & 1.42 & 1.35 & 1.38 & 89 & & \\
\hline N24 & 25 & 1.85 & 1.44 & 1.38 & 1.37 & 1.41 & 87 & & \\
\hline N23 & 0 & 1.86 & 1.45 & 1.39 & 1.35 & 1.49 & 87 & & \\
\hline N26 & 75 & 1.78 & 1.88 & 1.96 & 2.08 & 1.96 & - & & \\
\hline N26 & 50 & 1.83 & 1.74 & 1.82 & 1.87 & 1.87 & - & & \\
\hline N28 & 25 & 1.80 & 1.68 & 1.70 & 1.67 & 1.66 & - & & \\
\hline
\end{tabular}

(1) Samples N21 - N25 were prepared by blending truxene and isotruxene. Samples were air cured in a programmed cycle to $250^{\circ} \mathrm{C}$ and were subsequently carhnnized to $1,000^{\circ} \mathrm{C}$. Samples N26 - N28 were prepared by blending $1,000^{\circ} \mathrm{C}$ cokes of truxene and isotruxene. 


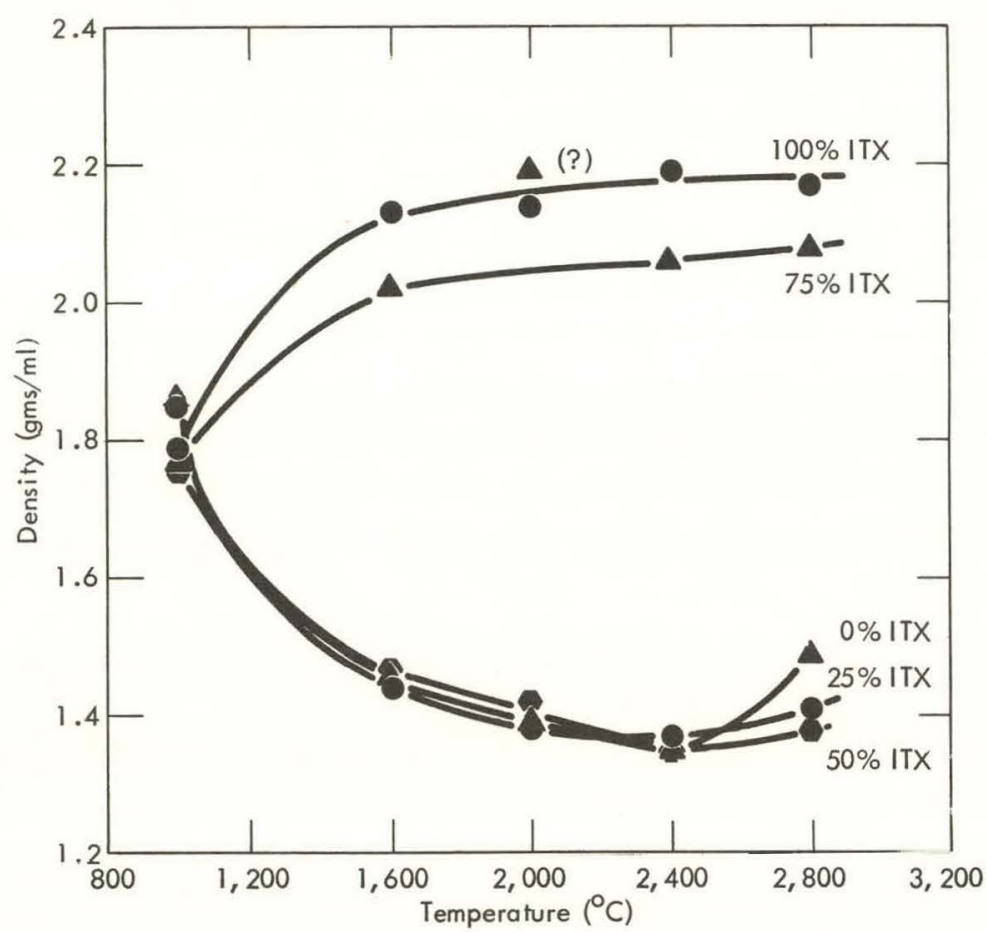

Figure 79. DENSITY (BY HELIUM DISPLACEMENT) OF CARBON SAMPLES DERIVED FROM TRUXENE-ISOTRUXENE MIXTURES AS A FUNCTION OF THE FIRING TEMPERATURE.

density data revealed essentially two types of sarbon: (1) samples high in isotruxene content (75 and 100\%) yielded carbons which increased in density on firing above $1,000^{\circ} \mathrm{C}$; (2) those carbons from samples low in isotruxene decreased in density. The former denotes the formation of graphitic carbon while the latter denotes the formation of nongraphitic carbon with closed porosity. Of significance was the absence of densities that would be predicted on the basis of a weighted average of the properties of the individual carbons. Thus, interaction did occur and did produce copolymers that were different from the physical mixtures of the two precursor materials.

Included in Table 28 are density data for three carbon samples that were prepared by blending $1,000^{\circ} \mathrm{C}$ cokes derived from truxene and isotruxene. As expected, these carbons display properties that would be predicted from weighted averages of the component carbons. This is apparent in Figure 80 which allows a comparison of the density data of carbons (after $2,800^{\circ} \mathrm{C}$ ) derived from precursor blends with those prepared by blending carbons.

$X$-ray data for the more graphitic carbons are included in Table 28. The diffraction scans in Figure 81 show the transition in instrument response corresponding to the primary reflection (002) of the carbons as a function of the precursor composition. Figure 81 suggests that the 100 percent truxene sample 


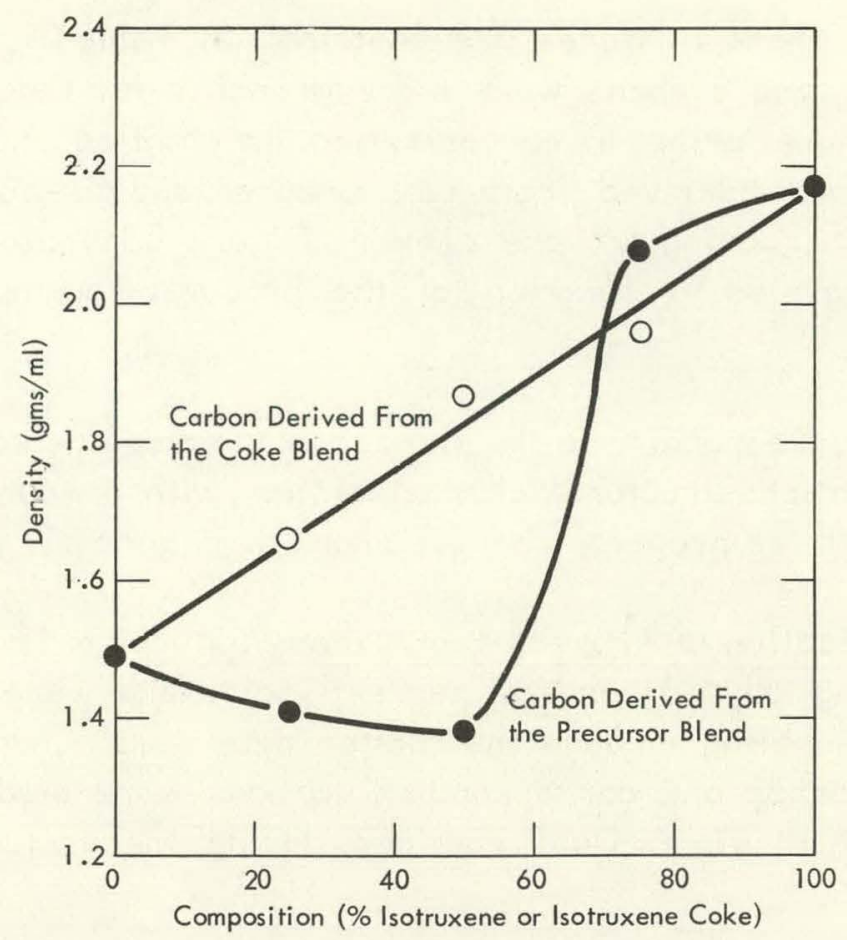

Figure 80. DENSITY (BY HELIUM DISPLACEMENT) OF CARBON SAMPLES (AFTER $2,800^{\circ} \mathrm{C}$ ) DERIVED FROM TRUXENEISOTRUXENE MIXTURES, OR FROM MIXTURES OF THEIR RESPECTIVE COKES.

produced a carbon with somewhat greater order than the nongraphitic carbons produced from mixtures containing 25 and 50 percent isotruxene. The same conclusion would be reached by comparing the densities of carbons (after $2,800^{\circ} \mathrm{C}$ ) corresponding to these samples in Figure 79 .

Microstructures of those carbons corresponding to precursor mixtures containing 100, 75, and 50 percent isotruxene are shown in Figure 82. The transition in microstructure with precursor composition is quite apparent, and is in support of the density data previously discussed. Thus, control over these compositions of truxene-isotruxene mixtures should allow control of the properties of derived carbon.

A second series of carbons were derived from truxene-isotruxene mixtures that were formulated by blending isotruxene with truxene-isotruxene mixtures that are produced by autoclave polymerization of indene. (8) The autoclave products are typically 55-65 percent isotruxene. The resulting blends of truxene and isotruxene that were evaluated contained approximately 11, 17, 23 , and 34 percent truxene. These mixtures represent composition ranges over which major microstructural changes were observed for derived carbons; and, thus, are representative of the precursor composition range over which microstructural control of the derived carbon is possible. 
Data obtained for these mixtures are contained in Table 29. In general, coke yields were higher and carbons were more graphitic for those samples which received an air cure prior to carbonization. In addition, the graphitic properties of the carbons derived from both uncured and air-cured samples decreased with an increasing truxene content. Figure 83 shows the variation in graphitic properties as a function of the precursor composition and cure conditions.

Microstructures corresponding to the air-cured samples are seen in Figure 84. Transition in the microstructural characteristics with precursor composition is in agreement with the property changes shown in Figure 83.

Oxidative Polymerization of Truxene-Isotruxene Mixtures - Truxene-isotruxene mixtures containing 58,70 , and 80 percent isotruxene were heated at $300^{\circ} \mathrm{C}$ with oxygen gas bubbling through the molten materials. Changes in the properties of the precursor and corresponding carbons were studied as a function of the heat-treatment time. Data obtained during these studies are given in

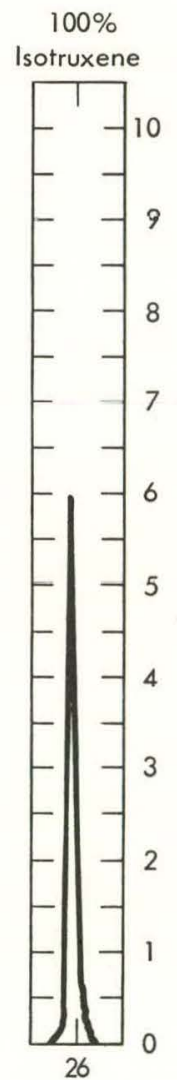

(a)

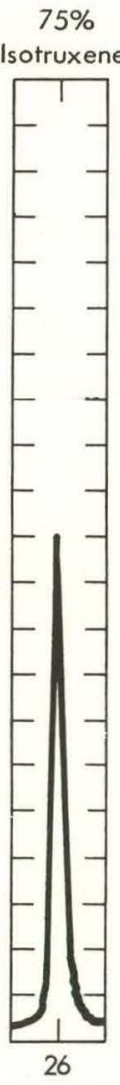

(b)

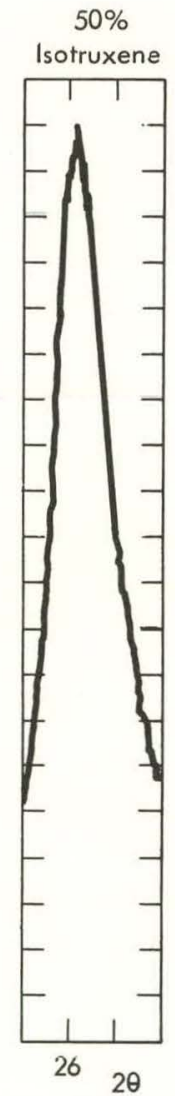

(c)

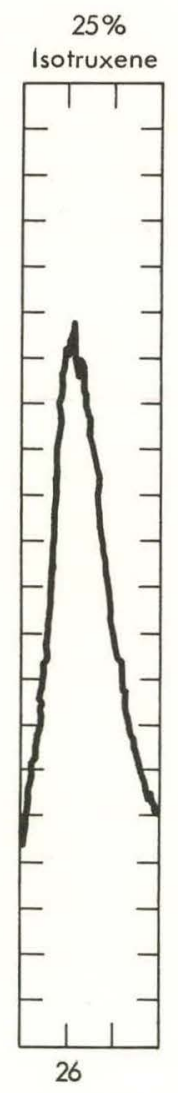

(d)

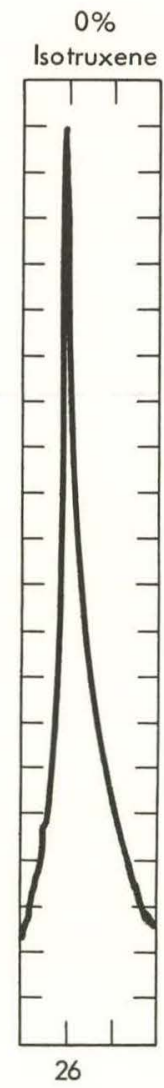

(e)

Figure 81. X-RAY DIFFRACTION SCANS (002 PLANE) OF CARBON SAMPLES (AFTER $2,800^{\circ} \mathrm{C}$ ) DERIVED FROM MIXTURES OF ISOTRUXENE AND TRUXENE. 


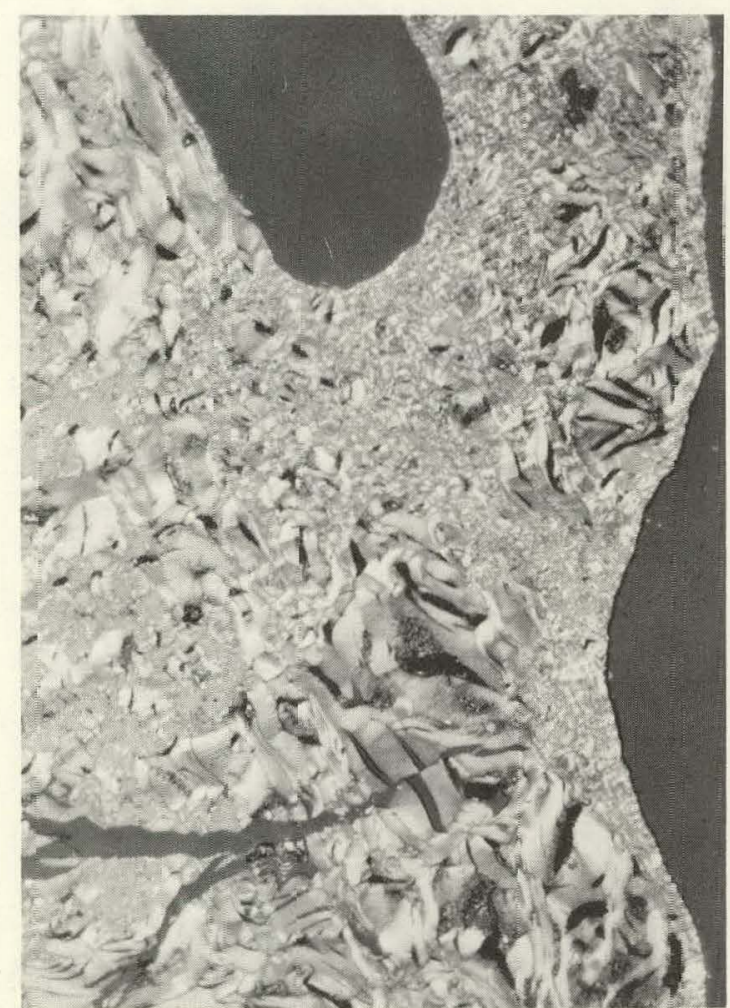

(a) With 100\% ITX

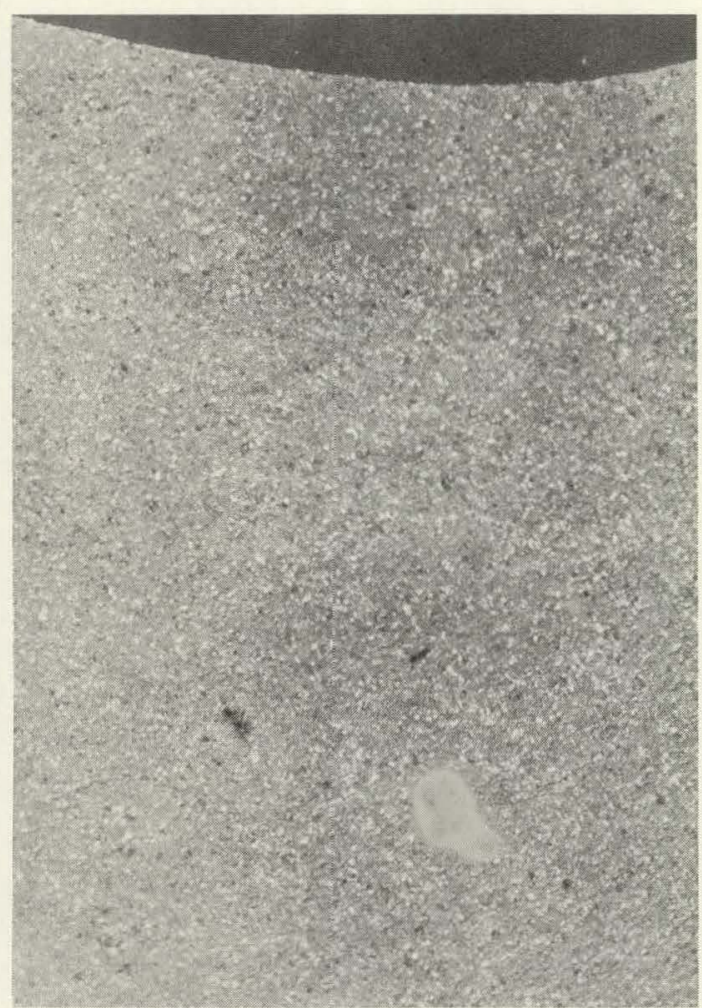

E189-2

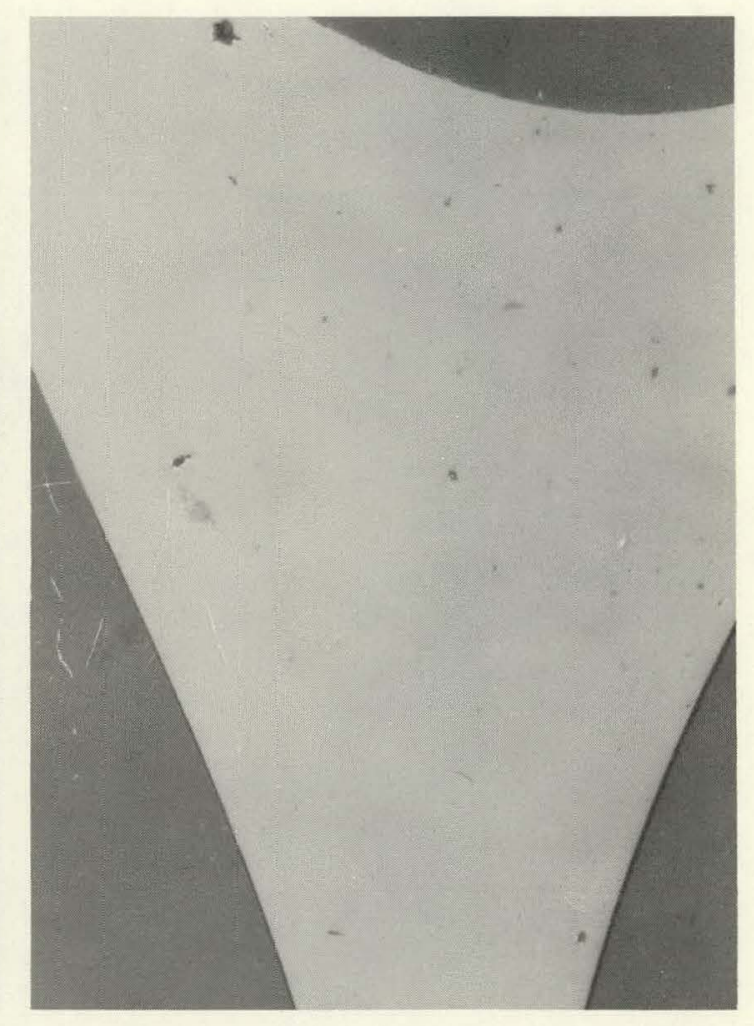

(c) With $50 \%$ ITX

E189-3 


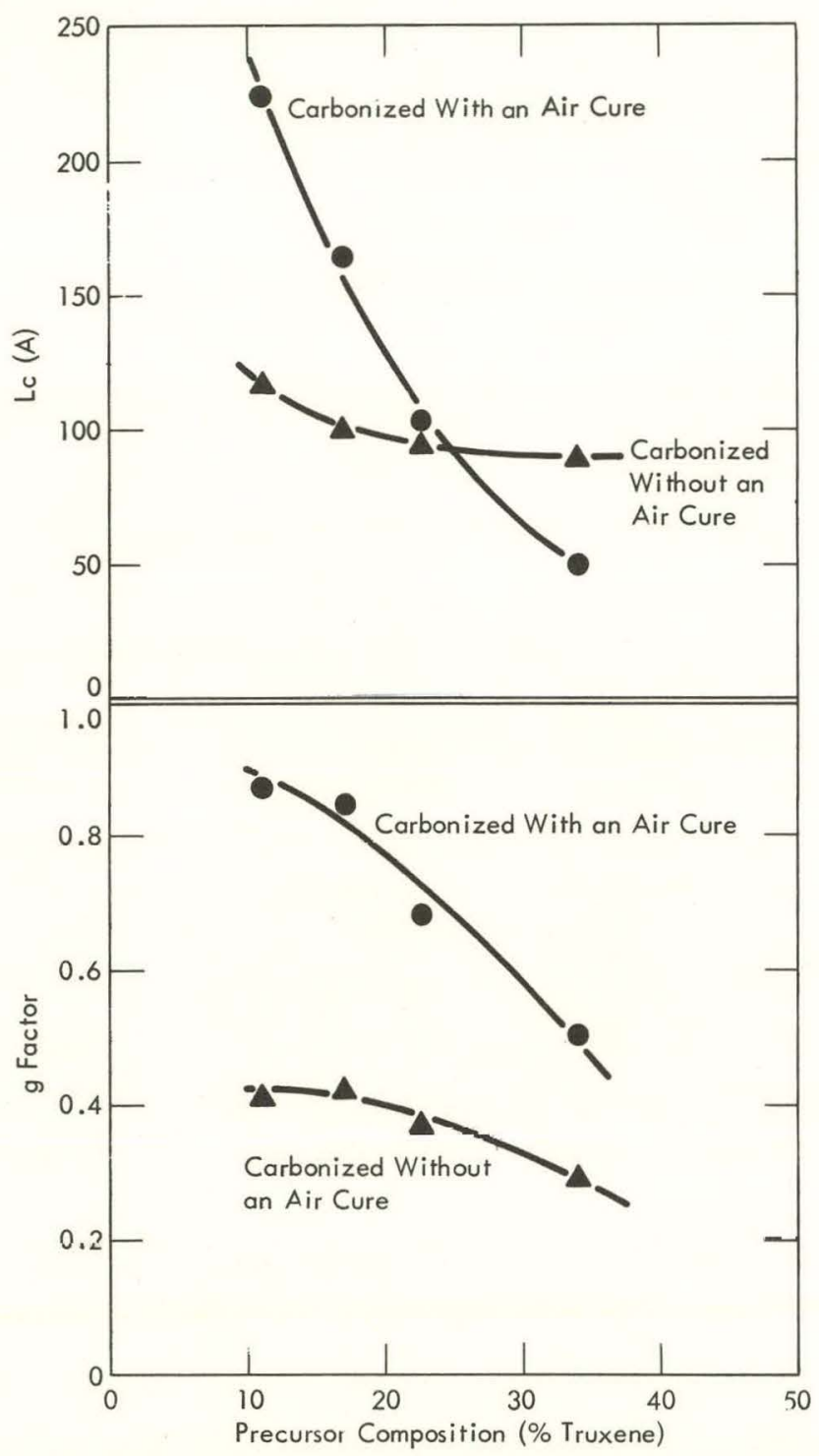

Figure 83. (RYSIALLIIE SIZE AND g FACTOR OF CARBON SAMPLES (AFTER 2,800 C) DERIVED FROM TRUXENE-ISOTRUXENE MIXTURES AS FUNCTIONS OF THE TRUXENE COMPOSITION.

Table 30. The graph of Figure 85 shows viscosity changes as a function of the oxygen uptake during heat treatment. As indicated in Figure 86, coke yields of the heat-treated samples were observed to increase markedly with initial increases in the pitch viscosity before becoming essentially constant at viscosity values above approximately $100 \mathrm{cp}$.

Changes in the graphitic properties of derived carbons with heat-treatment time are apparent in Table 30. In general, graphiticity increased with increasing oxidation, as was observed for other truxene-isotruxene systems. 

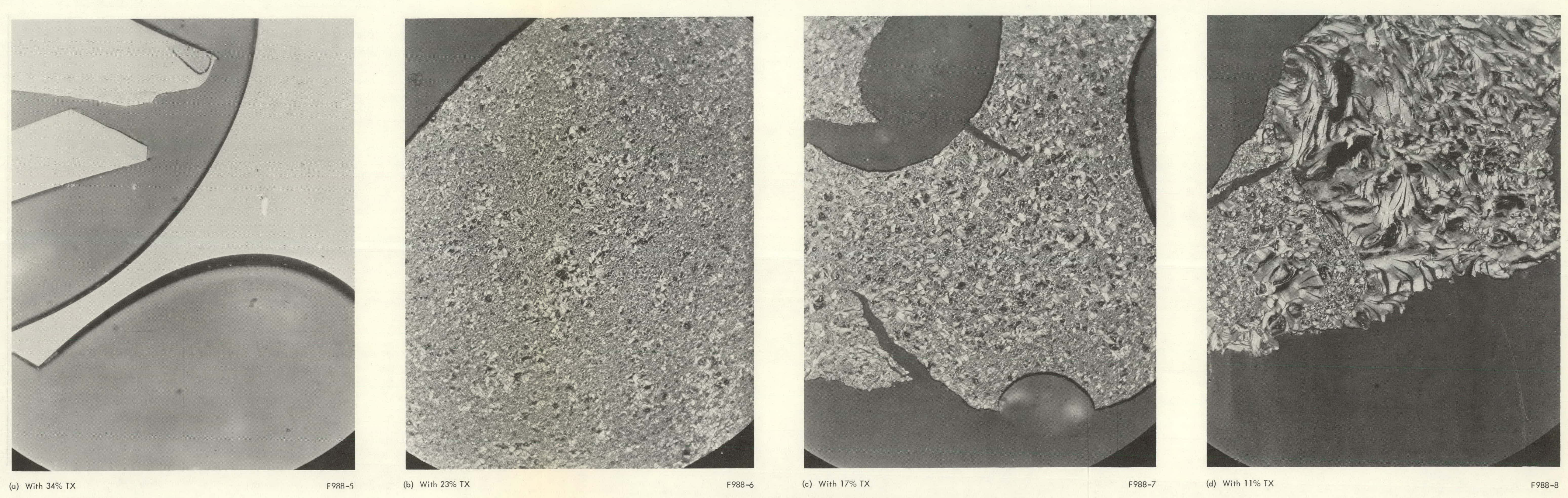

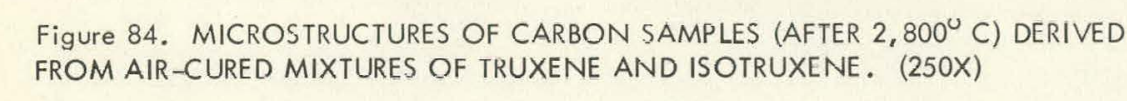


Table 29

PROPERTIES OF CARBONS FROM TRUXENE-ISOTRUXENE MIXTURES

\begin{tabular}{|c|c|c|c|c|c|c|}
\hline \multirow[b]{2}{*}{$\begin{array}{c}\text { Sample } \\
\text { Number }(1)\end{array}$} & \multirow{2}{*}{$\begin{array}{c}\text { Truxene } \\
\text { Content } \\
(\%)\end{array}$} & \multirow[b]{2}{*}{$\begin{array}{c}\text { Air } \\
\text { Cure (2) }\end{array}$} & \multirow{2}{*}{$\begin{array}{c}\text { Carbon Yield } \\
\text { After } \\
1,000^{\circ} \mathrm{C} \\
(\%)\end{array}$} & \multicolumn{3}{|c|}{ Properties After $2,800^{\circ} \mathrm{C}$} \\
\hline & & & & $\begin{array}{l}\text { do04 } \\
\text { (A) }\end{array}$ & $g$ factor & $\begin{array}{l}L_{c} \\
(A)\end{array}$ \\
\hline $11-6-69 A 1$ & 34 & Yes & $94(?)$ & 1.6984 & 0.506 & 50 \\
\hline $11-6-69 A 2$ & 23 & Yes & 75 & 1.6911 & 0.682 & 103 \\
\hline $11-6-69 A 3$ & 17 & Yes & 75 & 1.6842 & 0.847 & 164 \\
\hline $11-6-69 A 4$ & 11 & Yes & 68 & 1.6828 & 0.871 & 224 \\
\hline $11-6-69 B 1$ & 34 & No & 49 & 1.7074 & 0.294 & 90 \\
\hline $11-6-69 \mathrm{~B} 2$ & 23 & No & 45 & 1.7039 & 0.376 & 95 \\
\hline $11-6-6983$ & 17 & No & 40 & 1.7022 & 0.424 & 100 \\
\hline $11-6-69 B 4$ & 11 & No & 49 & 17025 & 0.112 & 117 \\
\hline
\end{tabular}

(1) Samples were prepared by blending an isotruxene product ( $~ 75 \%$ isotruxeneprepured by heating indene and 1,4-naphthoquinone under reflux) with a truxene-isotruxene mixture ( $64 \%$ isotruxene-prepared by heating indene in an autoclave).

(2) Air cure consisted of heating 30 -gram samples to $250^{\circ} \mathrm{C}$ in a programmed cycle covering $\sim 50$ hours.

Table 30

EFFECT OF HEAT TREATMENT $\left(300^{\circ} \mathrm{C}\right.$ ) IN OXYGEN (FLOW RATE, $84 \mathrm{CC} / \mathrm{MIN}$ ) ON PROPERTIES OF TRUXENE-ISOTRUXENE MIXTURES AND CARBONS DFRIVED FR.OM THESE MIXTURE'S

\begin{tabular}{|c|c|c|c|c|c|c|c|c|}
\hline \multirow[b]{2}{*}{$\begin{array}{l}\text { Time } \\
\text { (hrs) }\end{array}$} & \multirow[b]{2}{*}{$\begin{array}{c}\text { Viscosity }(1) \\
(\mathrm{cp})\end{array}$} & \multirow{2}{*}{$\begin{array}{c}\text { Oxygen } \\
\text { Content (2) } \\
(\%)\end{array}$} & \multirow{2}{*}{$\begin{array}{l}\text { Melting } \\
\text { Range } \\
\left({ }^{\circ} \mathrm{C}\right)\end{array}$} & \multirow{2}{*}{$\begin{array}{c}\text { Apparent } \\
\text { Monomer } \\
\text { Content (3) } \\
(\%)\end{array}$} & \multirow{2}{*}{$\begin{array}{c}\text { Coke Yield } \\
\text { After } \\
1,000^{\circ} \mathrm{C} \\
(\%)\end{array}$} & \multicolumn{3}{|c|}{$\begin{array}{c}\text { Carbon Properties } \\
\text { After } 2,800^{\circ} \mathrm{C}\end{array}$} \\
\hline & & & & & & $\begin{array}{l}\mathrm{d} 004 \\
(\mathrm{~A})\end{array}$ & $\mathrm{g}$ fastotor & $\begin{array}{l}L_{c} \\
\text { (A) }\end{array}$ \\
\hline
\end{tabular}

Batch 10-98-69 (isotruxene content $80 \%$ )

$\begin{array}{rrrrrrrrr}0 & 18 & - & 208-246 & 81 & 40 & & & \\ 24 & 48 & 0.7 & 108-184 & - & 63 & 1.6879 & 0.711 & 105 \\ 48 & 120 & 1.1 & 137-165 & 65 & 71 & 1.6894 & 0.678 & 117 \\ 72 & 325 & 1.3 & 156-188 & 62 & 70 & 1.6865 & 0.744 & 156\end{array}$

Batch 10-86-69 (isotruxene content 70\%)

\begin{tabular}{rrrrrrrrr}
0 & 18 & - & $196-258$ & 82 & 38 & 1.7080 & 0.267 & 93 \\
24 & 50 & 0.3 & $99-184$ & 73 & 62 & 1.6908 & 0.644 & 108 \\
48 & 117 & 1.0 & $168-228$ & 63 & 71 & 1.6894 & 0.667 & 105 \\
72 & 720 & 1.1 & $178-232$ & 57 & 78 & 1.6777 & 0.944 & 124 \\
& & \multicolumn{7}{r}{ Batch 10-96-69 (isotruxene content 58\%) } \\
0 & 18 & 0.1 & $208-244$ & - & 31 & 1.7051 & 0.333 & 107 \\
24 & 86 & 0.6 & $191-232$ & - & 67 & 1.6923 & 0.611 & 93 \\
42 & 386 & 0.9 & $171-220$ & - & 76 & 1.6911 & 0.644 & 107 \\
\hline
\end{tabular}

(1) Measured by a Brookfield viscometer at $300^{\circ} \mathrm{C}$.

(2) Determined by neutron activation.

(3) Estimated from molecular distributions in GPC scans. 


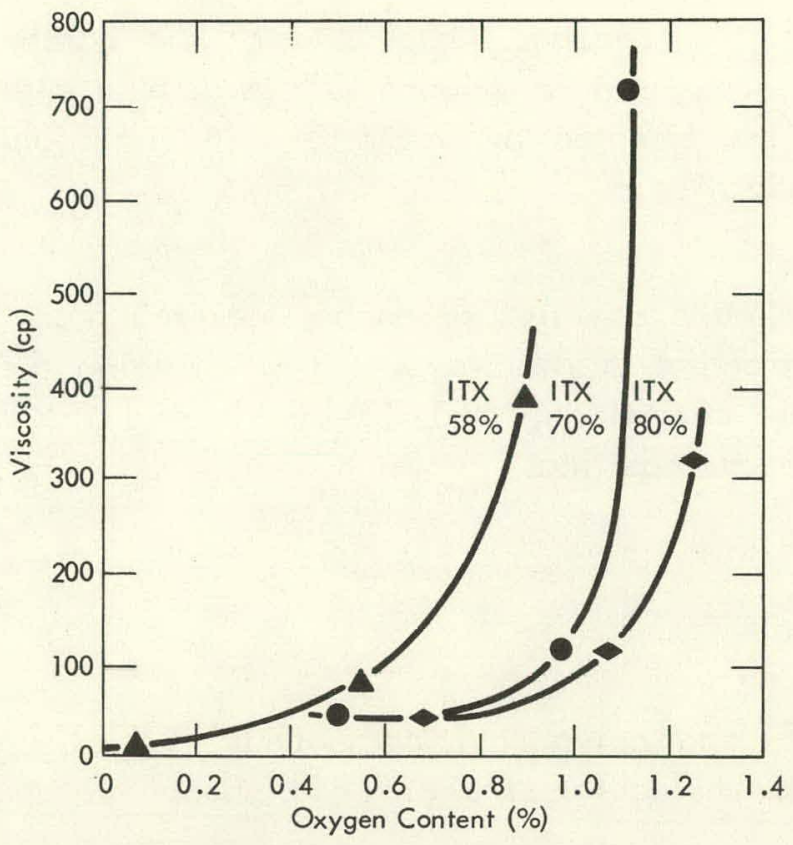

Figure 85. VISCOSITY (AT $300^{\circ}$ C) OF TRUXENE-ISOTRUXENE MIXTURES AS A FUNCTION OF THE OXYGEN CONTENT ON HEATING AT $300^{\circ} \mathrm{C}$ IN OXYGEN GAS. (Flow Rate, $84 \mathrm{cc} / \mathrm{min}$ )

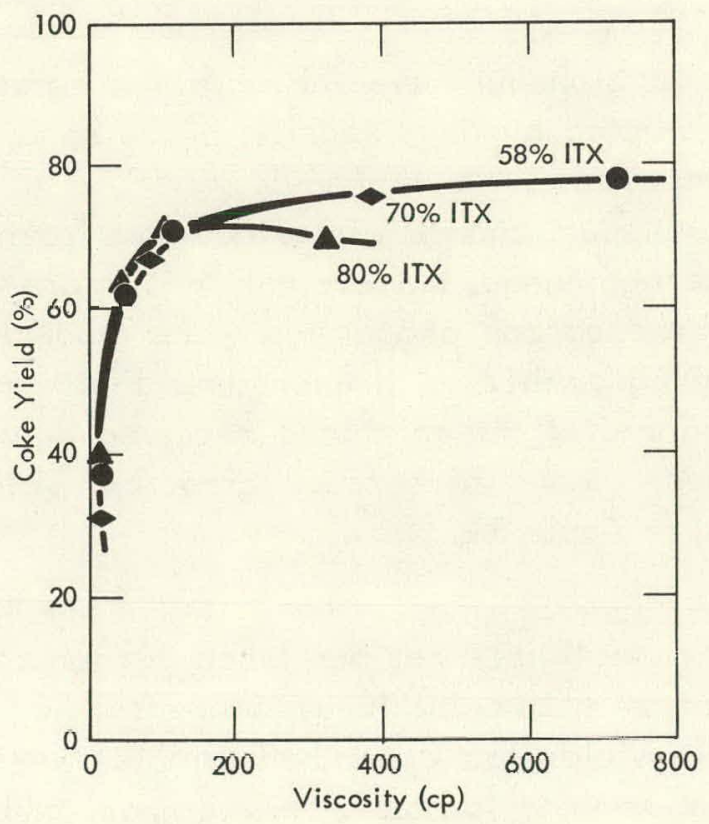

Figure 86. COKE YIELD (AFTER $1,000^{\circ} \mathrm{C}$ ) OF TRUXENE-ISOTRUXENE MIXTURES AS A FUNCTION OF THE VISCOSITY (AT $300^{\circ} \mathrm{C}$ ) ON HEAT TREATMENT AT $300^{\circ} \mathrm{C}$ IN OXYGEN. (Flow Rate, $84 \mathrm{cc} / \mathrm{min}$ ) 
Microstructures of the carbons from one of the batches (10-86-69) listed in Table 30 are presented in Figure 87 as an example of microstructural changes that can be effected by variations in time subjected to conditions of oxidative polymerization.

Thus, variation in the properties of carbon derived from truxene-isotruxene mixtures can be modified in two ways: (1) by changing the composition using constant processing conditions, and (2) by varying the heat-cure time for mixtures of constant composition.

Isotruxene-Biphenyl Mixtures

Biphenyl, terphenyl, and polyphenyl compounds typically yield carbons that are nongraphitic. The molecular structure of biphenyl is:

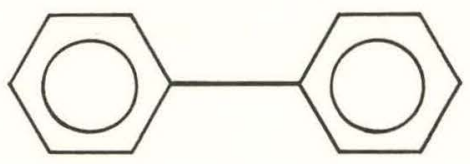

biphenyl

The ring constituents in biphenyl have the ability to rotate about an imaginary axis that could be depicted by an extension of the bond joining the two rirys. This freedom to rotate allows a biphenyl molecule to assume various conformations that are nonplanar, and thus intermediates formed on polymerization of biphenyl tend to be nonplanar. An evaluation of biphenyl/ITX mixtures was conducted to see how the carbon properties were modified by the combination of graphitizing and nongraphitizing precursors. ITX and biphenyl were dry blended as powders. Some of the mixtures received an air cure prior to carbonization while others were carbonized directly. Data obtained for these samples are presented in Table 31.

Since biphenyl yields a negligible residue when carbonized at one atmosphere of pressure, coke yields of the mixtures decreased with increasing biphenyl content. However, coke yields for air-cured samples were significanlly higher than those observed for uncured samples. This comparison is shown in Figure 88 which also suggests that some interaction between ITX and biphenyl occurred for the air-cured samples containing 0 - 25 percent biphenyl. At higher biphenyl concentrations, the coke-yield values actually describe a negative deviation 

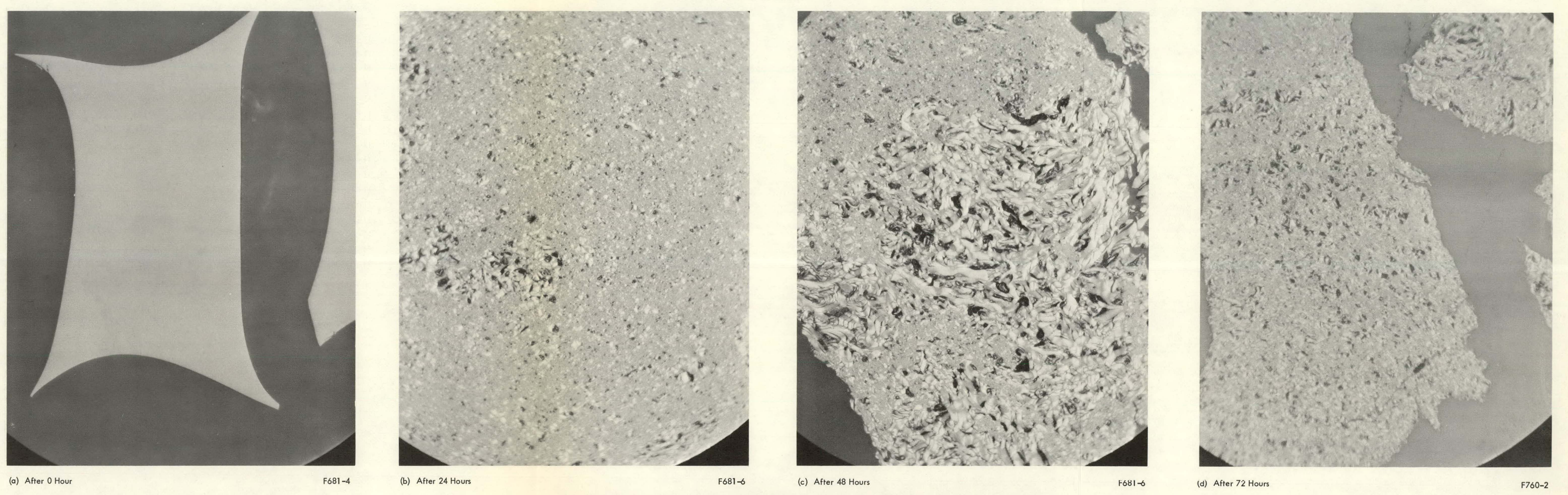

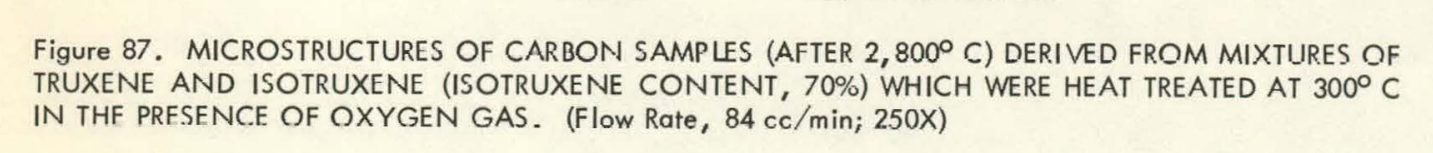


Table 31

PROPERTIES OF CARBON DERIVED FROM

ISOTRUXENE-BIPHENYL MIXTURES

\begin{tabular}{|c|c|c|c|c|c|c|}
\hline \multirow[b]{2}{*}{$\begin{array}{l}\text { Sample } \\
\text { Number }\end{array}$} & \multirow{2}{*}{$\begin{array}{c}\text { Biphenyl } \\
\text { Content } \\
(\%)\end{array}$} & \multirow[b]{2}{*}{$\begin{array}{c}\text { Air } \\
\text { Cure (1) }\end{array}$} & \multirow{2}{*}{$\begin{array}{c}\text { Coke Yield } \\
\text { After } \\
1,000^{\circ} \mathrm{C} \\
(\%)\end{array}$} & \multicolumn{3}{|c|}{$\begin{array}{c}\text { Properties After } \\
2,800^{\circ} \mathrm{C}\end{array}$} \\
\hline & & & & $\begin{array}{l}\mathrm{d} 004 \\
(\mathrm{~A})\end{array}$ & $\mathrm{g}$ factor & $\begin{array}{l}L_{C} \\
(A) \\
\end{array}$ \\
\hline $11-5-69 A 1$ & 0 & Yes & 73 & 1.6828 & 0.870 & 227 \\
\hline $11-5-69 A 2$ & 5 & Yes & 74 & 1.6831 & 0.870 & 210 \\
\hline $11-5-69 A 3$ & 10 & Yes & 68 & 1.6836 & 0.859 & 203 \\
\hline $11-5-69 \mathrm{~A} 4$ & 15 & Yes & 67 & 1.6848 & 0.823 & 184 \\
\hline $11-5-69 A 5$ & 20 & Yes & 64 & 1.6857 & 0.812 & 151 \\
\hline $11-5-69 A 6$ & 25 & Yes & 54 & 1.6888 & 0.730 & 118 \\
\hline $11-36-70 A 1$ & 35 & Yes & 37 & - & - & - \\
\hline $11-36-70 A 2$ & 50 & Yes & 20 & - & - & - \\
\hline $11-36-70 A 3$ & 75 & Yes & 13 & - & - & - \\
\hline $11-36-70 A 4$ & 100 & Yes & Negligible & - & - & - \\
\hline $11-5-69 \mathrm{~B} 1$ & 0 & No & 48 & 1.6946 & 0.600 & 96 \\
\hline $11-5-6982$ & 5 & No & 43 & 1.6955 & 0.577 & 101 \\
\hline $11-5-6983$ & 10 & No & 39 & 1.6949 & 0.588 & 103 \\
\hline $11-5-69 B 4$ & 15 & No & 36 & 1.6955 & 0.577 & 104 \\
\hline $11-5-6985$ & 20 & No & 31 & 1.6946 & 0.600 & 101 \\
\hline $11-5-69 B 6$ & 25 & No & 30 & 1.6946 & 0.600 & 105 \\
\hline
\end{tabular}

(1) Air cure consisted of heating in a programmed cycle to a maximum of $250^{\circ} \mathrm{C}$.

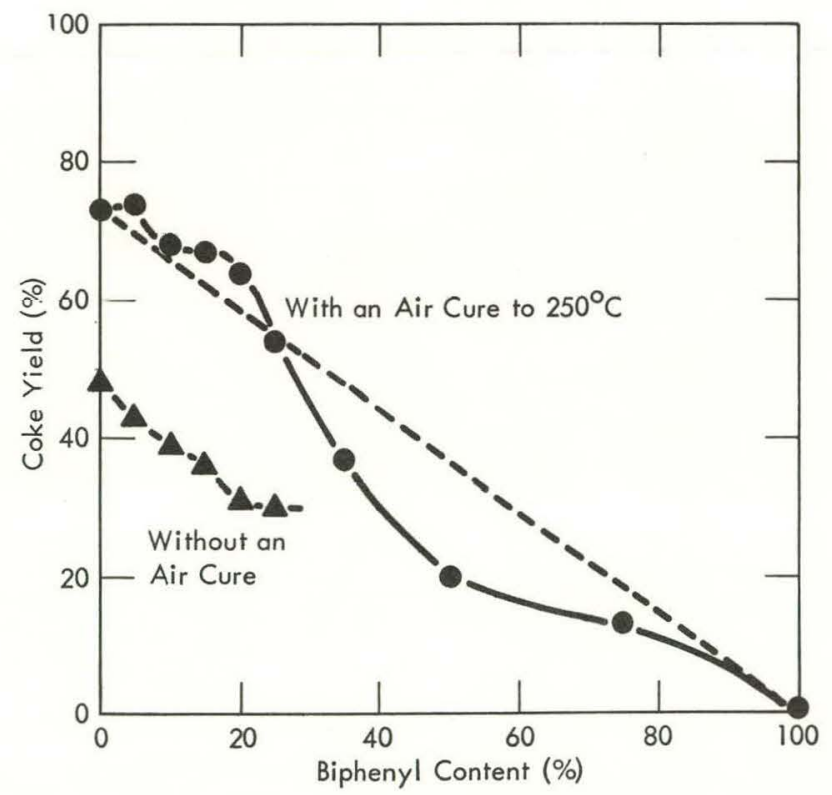

Figure 88. COKE YIELDS (AFTER $1,000^{\circ} \mathrm{C}$ ) OF ISOTRUXENEBIPHENYL MIXTURES AS A FUNCTION OF THE BIPHENYL CONTENT. 
from the theoretical values, based on the weighted averages of the two components.

Properties of carbon derived from ITX-biphenyl mixtures are included in Table 31. Properties of carbon derived from uncured samples were essentially constant with precursor composition while those from air-cured samples showed a change with increasing biphenyl content. These facts are obvious in Figures 89 and 90 showing, respectively, g-factor and crystallite-size values as a function of the precursor composition. Decreases in graphiticity with increasing biphenyl content would be the expected change for mixtures in which ITX and biphenyl interact, as is apparently true for air-cured samples. Without interaction, the biphenyl would be lost through evaporation and the resulting carbon would thus not reflect its presence. The latter case apparently exists for the uncured samples.

An examination of the microstructures of carbons derived from ITX-biphenyl mixtures can be made in Figures 91 and 92 for uncured and air-cured samples, respectively. Note that the microstructural characteristics of the uncured samples remain relatively unchanged with changes in the precursor composition, while those from air-cured samples show a decrease in grain size with increasing biphenyl content. This trend is in agreement with the X-ray diffraction data shown in Table 31. Thus, some modification of the carbon

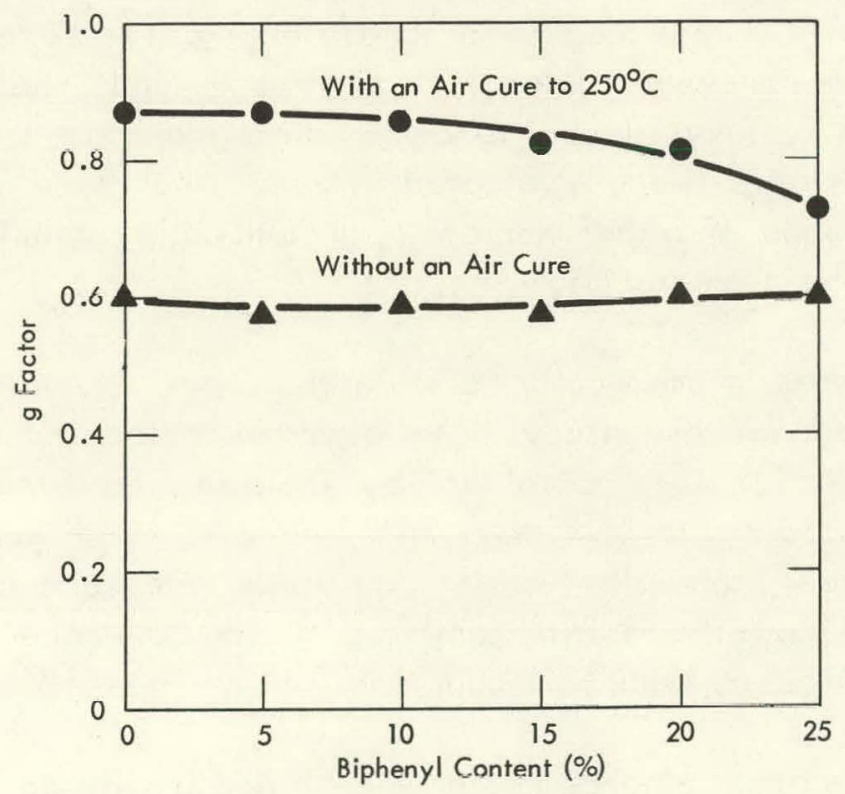

Figure 89. g FACTOR VALUES OF CARBON SAMPLES (AFTER $2,800^{\circ} \mathrm{C}$ ) DERIVED FROM ISOTRUXENE -BIPHENYL MIXTURES AS A FUNCTION OF THE BIPHENYL CONTENT. 


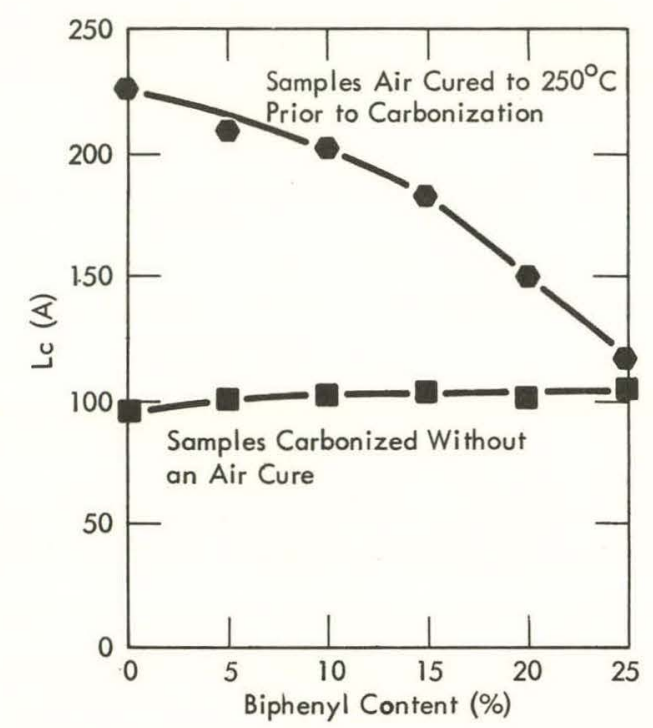

Figure 90. CRYSTALLITE SIZE OF CARBON SAMPLES (AFTER 2,800 C) DERIVED FROM ISOTRUXENE-BIPHENYL MIXTURES AS A FUNCTION OF THE BIPHENYL CONTENT.

properties can be obtained from air-cured blends of ITX and biphenyI, but uncured samples retain the properties characteristic of ITX-derived carbon.

Isotruxene-Polymerized Furfuryl Alcohol Mixtures

Polymers derived from furfuryl alcohol tend to thermoset on heating, to yield rigid materials with a high degree of crosslinking. The severe restrictions of molecular mobility prevent molecular alignment; and, thus, carbon derived from polymerized furfuryl alcohol tends to be nongraphitic. Isotruxene-furfuryl alcohol resin mixtures were evaluated to see what type of carbon would be produced from blends of a thermoplastic, graphitizing material with a thermosetting, nongraphitizing material.

Figure 93 indicates a molecular distribution that is typical of the furfuryl alcohol resin used in this study. The average-molecular-weight values included in Figure 93 were obtained by isolating the furfuryl alcohol resin fractions corresponding to the divisions indicated, and subsequently determining the average molecular weights by vapor pressure osmometry. Solids that were isolated from the resin by centrifugation had average-molecular-weight values in the range from 1,000 to 1,500 .

Samples of the furfuryl alcohol resin were blended with an air-cured form of ITX by milling, and the mixtures were subsequently carbonized to $1,000^{\circ} \mathrm{C}$. As shown in Table 32, a coke-yield value of approximately 50 percent was 

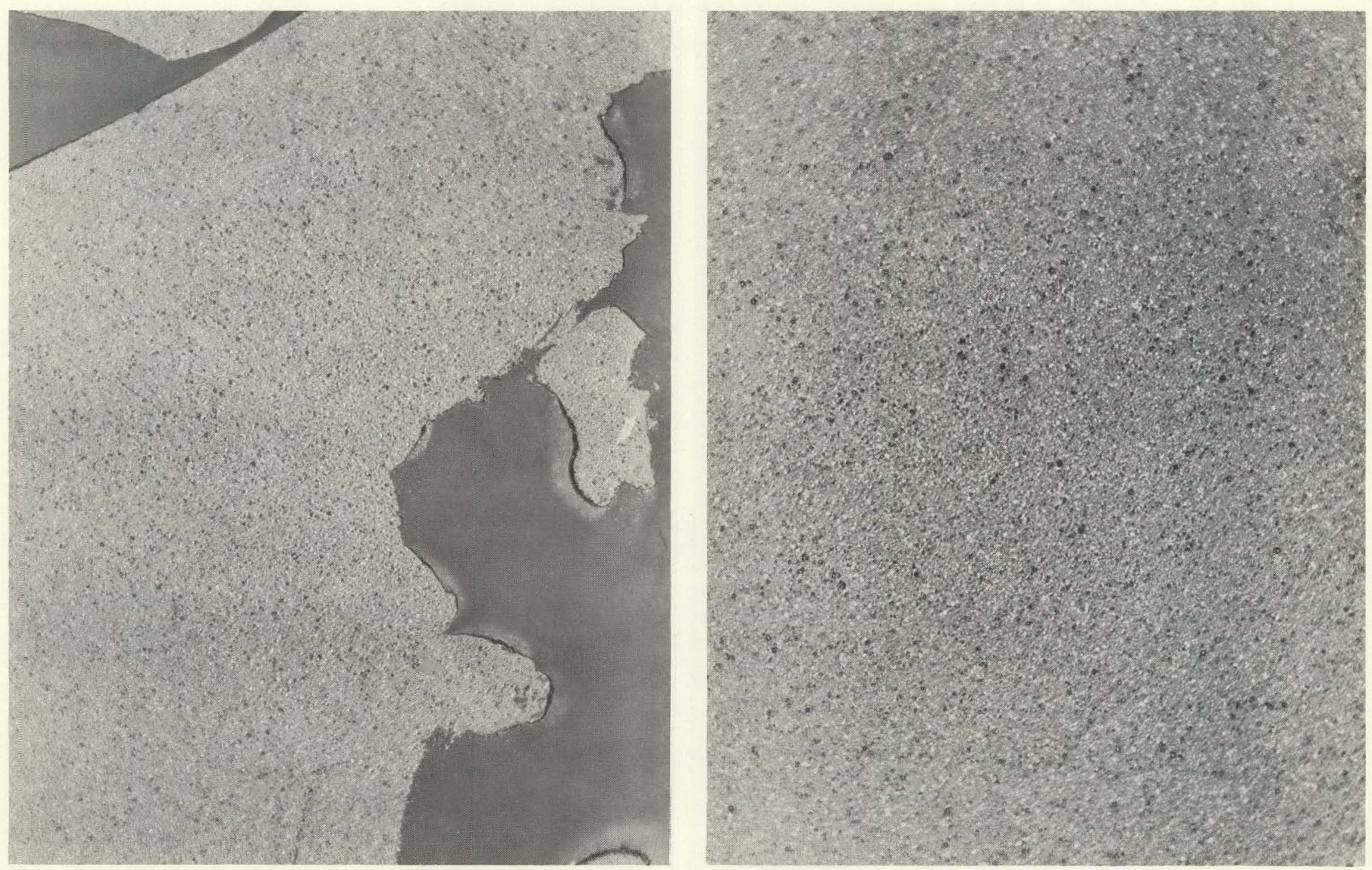

(a) With 0\% Biphenyl

F987-1 (b) With 25\% Biphenyl

F $987-6$

Figure 91. MICROSTRUCTURES OF CARBON SAMPLES (AFTER $2,800^{\circ}$ C) DERIVED FROM MIXTURES OF ISOTRUXENE AND BIPHENYL. (Batch 11-5-69B; 250X) 
Table 32

PROPERTIES OF CARBON DERIVED FROM MIXTURES OF POLYMERIZED FURFURYL ALCOHOL AND AIR-CURED ISOTRUXENE AS A FUNCTION OF THE TEMPERATURE

\begin{tabular}{|c|c|c|c|c|c|c|c|}
\hline $\begin{array}{c}\text { Batch } \\
\text { Number }(1)\end{array}$ & $\begin{array}{c}\text { Isotruxene } \\
\text { Content } \\
\text { (wt \%) }\end{array}$ & \multicolumn{5}{|c|}{ Density $(\mathrm{gm} / \mathrm{cc})$ at Temperature $\left({ }^{\circ} \mathrm{C}\right)$} & $\begin{array}{c}\text { Coke Yield, } \\
\text { Room } \\
\text { Temperature } \\
\text { to } 1,000^{\circ} \mathrm{C} \\
(\%)\end{array}$ \\
\hline N1 & 100 & 1.84 & 2.13 & 2.14 & 2.16 & 2.18 & 79 \\
\hline N2 & 80 & 1.75 & 2.09 & 2.07 & 2.04 & 2.27 (?) & $79(?)$ \\
\hline N3 & 60 & 1.77 & 2.02 & 2.03 & 2.10 & 2.04 & 64 \\
\hline N4 & 40 & 1.80 & 1.63 & 1.62 & 1.60 & 1.68 & 62 \\
\hline N5 & 20 & 1.71 & 1.52 & 1.51 & 1.56 & 1.50 & 56 \\
\hline N6 & 0 & 1.71 & 1.55 & 1.46 & 1.48 & 1.44 & 51 \\
\hline N7 & 80 & 1.83 & 2.07 & 2.02 & $2.15(?)$ & 1.93 & - \\
\hline N8 & 60 & 1.81 & 1.86 & 1.91 & 1.89 & 1.90 & - \\
\hline N9 & 40 & 1.78 & 1.76 & 1.75 & 1.81 & 1.80 & - \\
\hline N10 & 20 & 1.74 & 1.62 & 1.63 & 1.62 & 1.64 & - \\
\hline
\end{tabular}

(1) Samples N1 - N6 were prepared by mixing polymerized furfuryl alcohol and air-cured isotruxene in various ratios and subsequently carbonizing the mixtures to $1,000^{\circ} \mathrm{C}$. Samples N7 - N10 were prepared by initially carbonizing (to $1,000^{\circ} \mathrm{C}$ ) polymerized furfuryl alcohol (Varcum 8266) and isotruxene, and subsequently mixing the carbon residues in the described ratios. Maleic anhydride $(4 \mathrm{wt} \%)$ was added as a catalyst prior to carbonization of each sample.

obtained for the furfuryl alcohol resin. Since coke-yield values for the air-rured ITX are somewhat higher, coke-yield values increased with increasing ITX content. This fact is evident in Figure 94. Table 32 also lists the helium density data obtained for the resulting carbons as a function of the firing temperature in the range from 1,000 to $2,800^{\circ} \mathrm{C}$. For comparison, $1,000^{\circ} \mathrm{C}$ cokes derived individually from ITX and polymerized furfuryl alcohol were blended and fired to corresponding temperatures. A comparison of the density values from the coke mixtures with those from carbon derived from precursor blends should give an indication of the degree of interaction of ITX with polymerized furfuryl alcohol during carbonization. Density values for the carbons derived from the precursor blends are shown as a function of temperature in Figure 95, while those from the coke blends are shown in Figure 96. The latter results are similar to what would be calculated from a weighted average of the densities of carbon from the individual precursors. In comparison, the density values in Figure 95 suggest that some interaction between ITX and the furfuryl alcohol resin did occur during the carbonization step; and, though density values increased with increasing ITX content, the correlation was not linear. This fact is evident in Figure 97, which makes possible a direct comparison of densities as a function of the precursor composition for carbon (after $2,000^{\circ} \mathrm{C}$ ) derived from precursor blends with those obtained from coke blends. Thus, deviations from the linear curve suggest an interaction between the two precursors. 

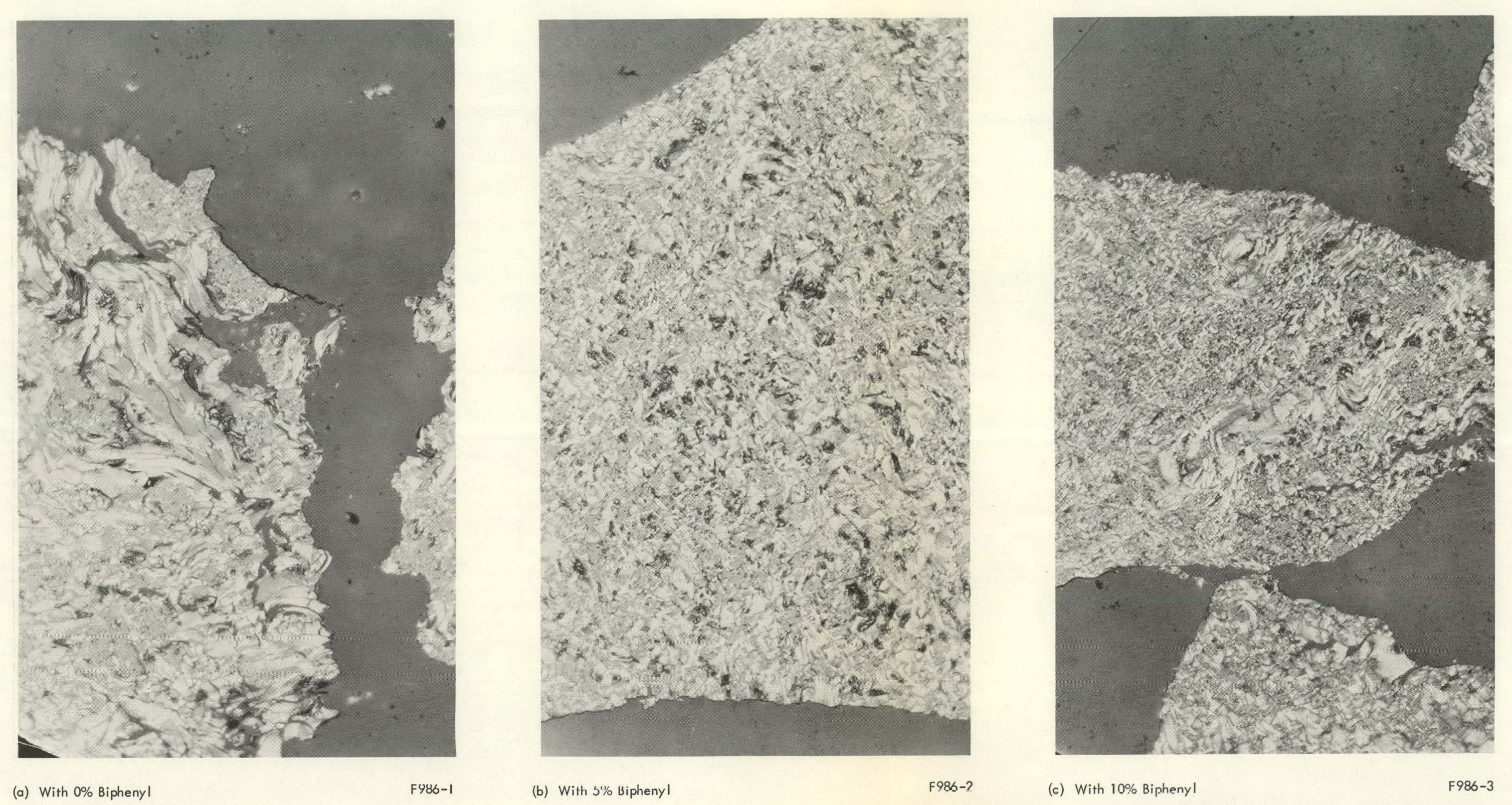

(b) With 5\% Bipheny

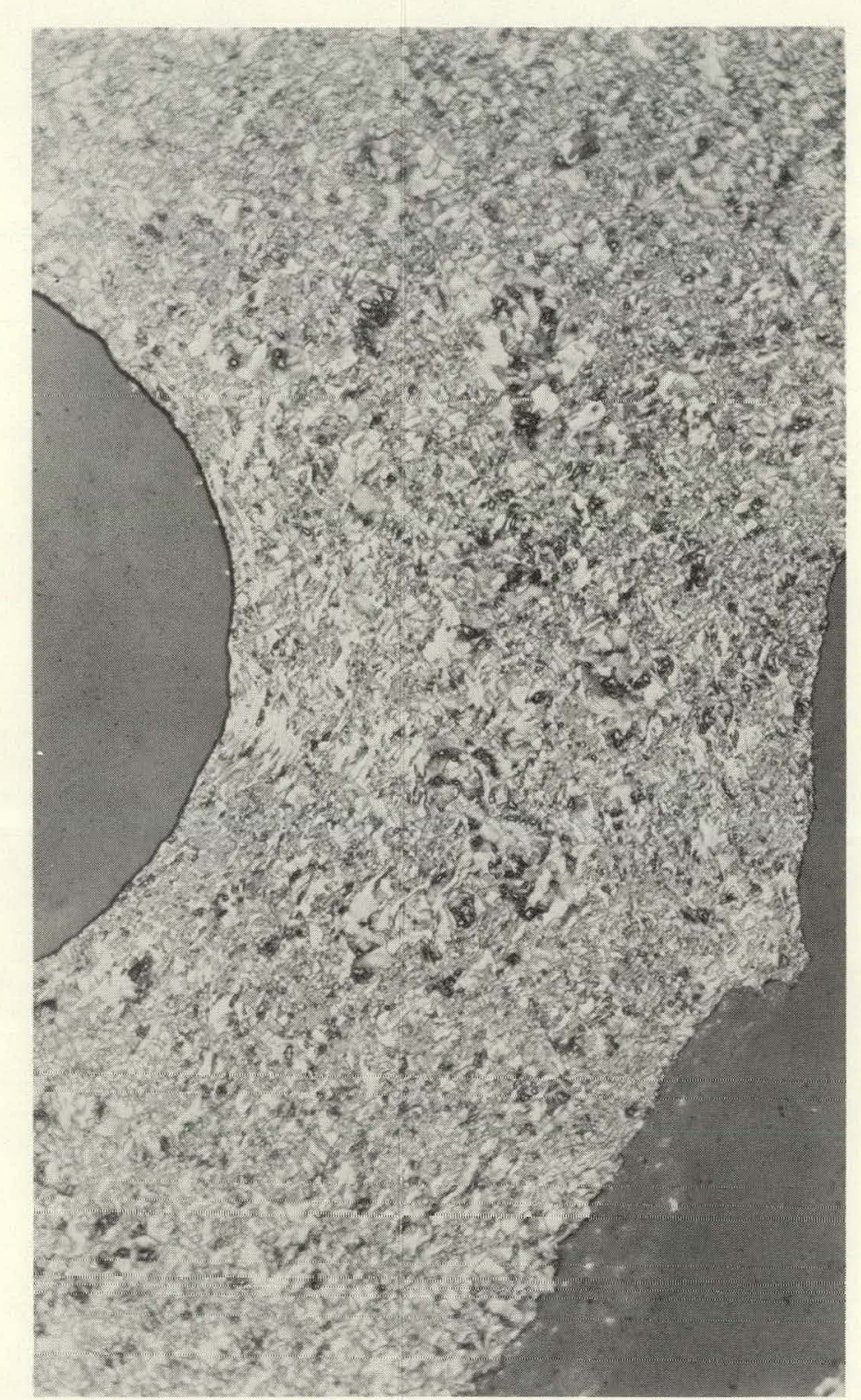

(d) With $15 \%$ Bipheny
F986-4

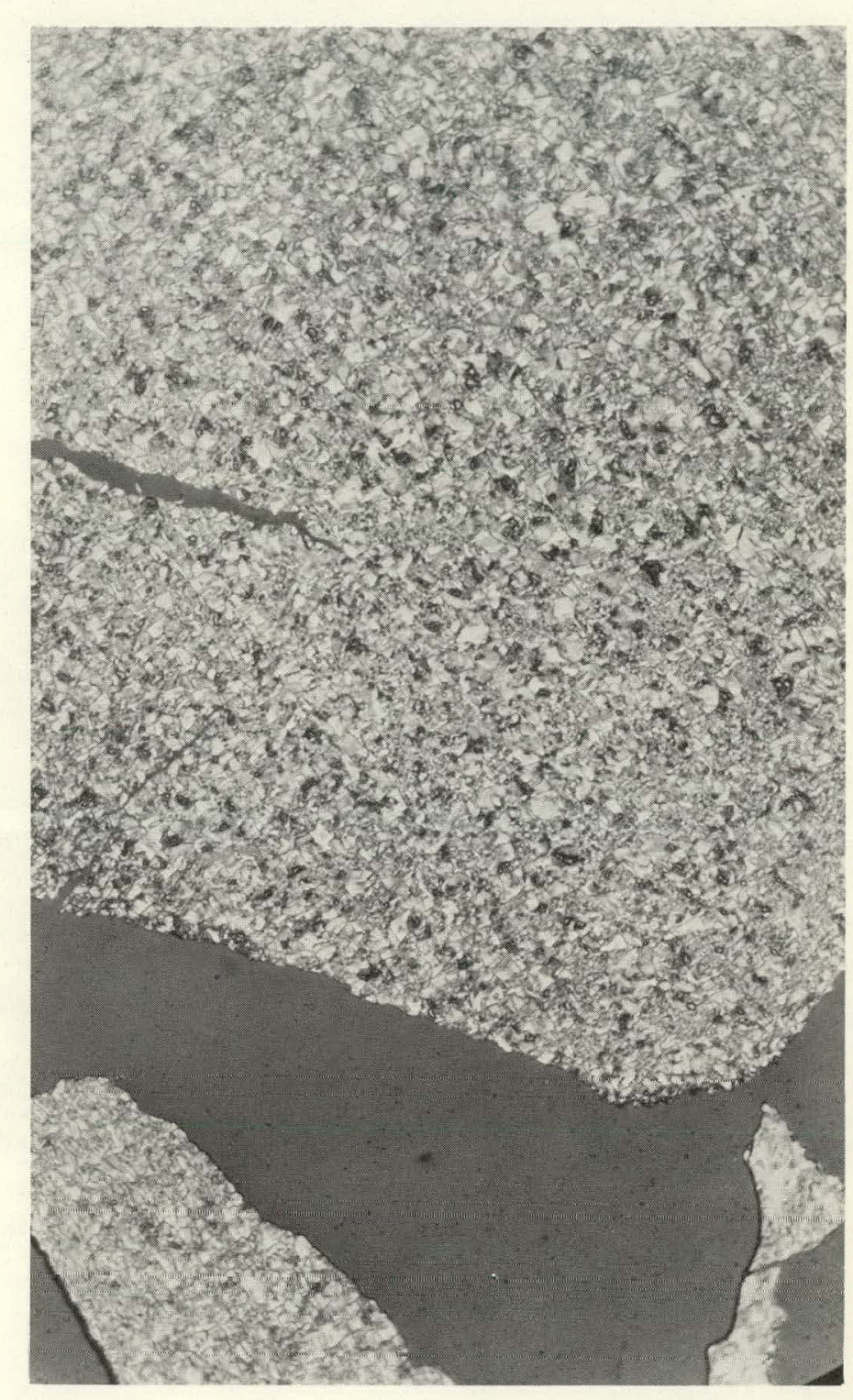

(e) With 25\% Biphenyl 


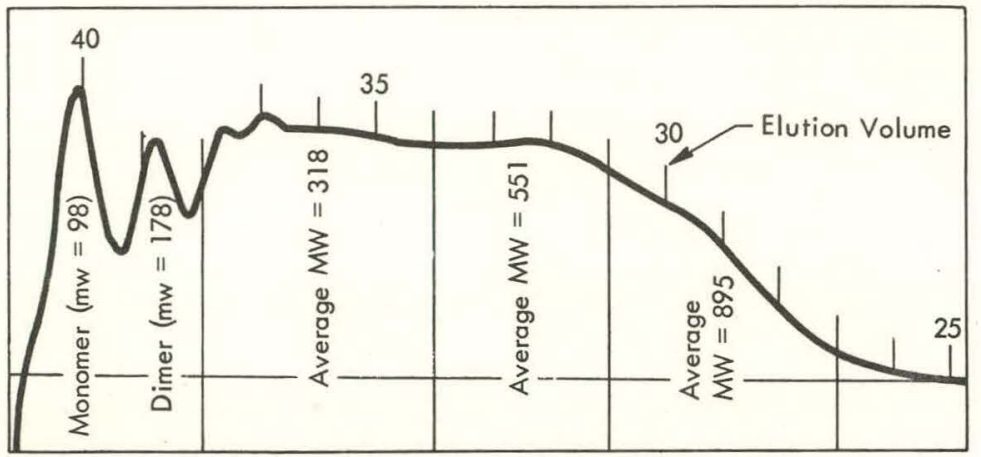

Figure 93. GEL PERMEATION CHROMATOGRAPHY SCAN SHOWING THE MOLECULAR WEIGHT DISTRIBUTION OF POLYMERIZED FURFURYL ALCOHOL.

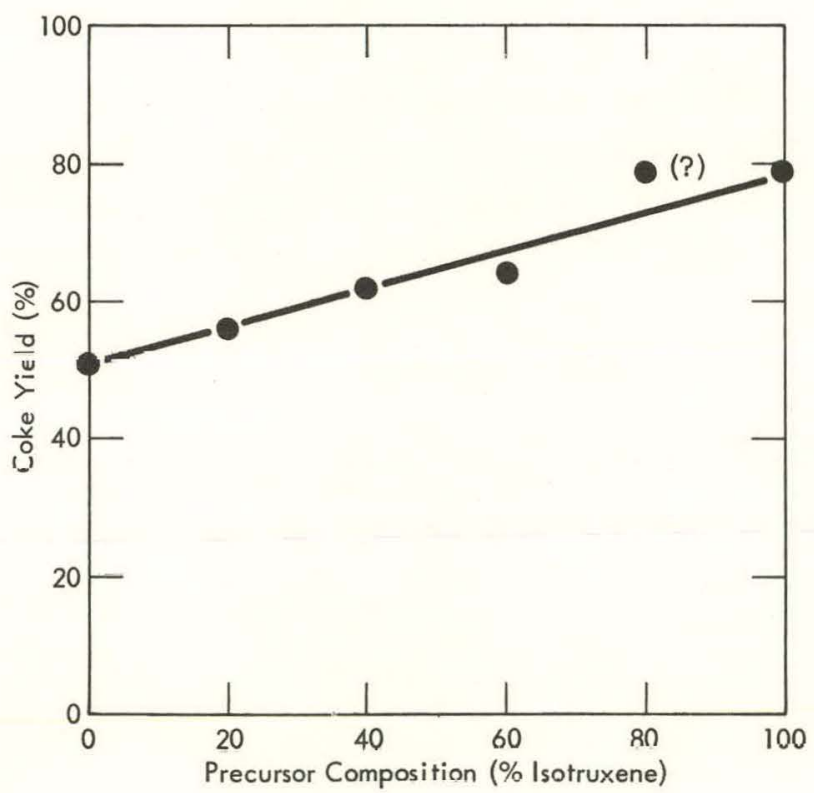

Figure 94. COKE YIELDS (AFTER $1,000^{\circ} \mathrm{C}$ ) OF AIR-CURED MIXTURES OF ISOTRUXENE AND POLYMERIZED FURFURYL ALCOHOL AS A FUNCTION OF THE COMPOSITION.

$X$-ray diffraction data indicated an increasing carbon crystallinity with increasing ITX content. The diffraction scans in Figure 98 show this trend, and also indicate a greater-than-average difference between samples that contained 40 and 60 percent ITX. As discussed previously, carbon-density values also changed markedly over this range of precursor compositions. 


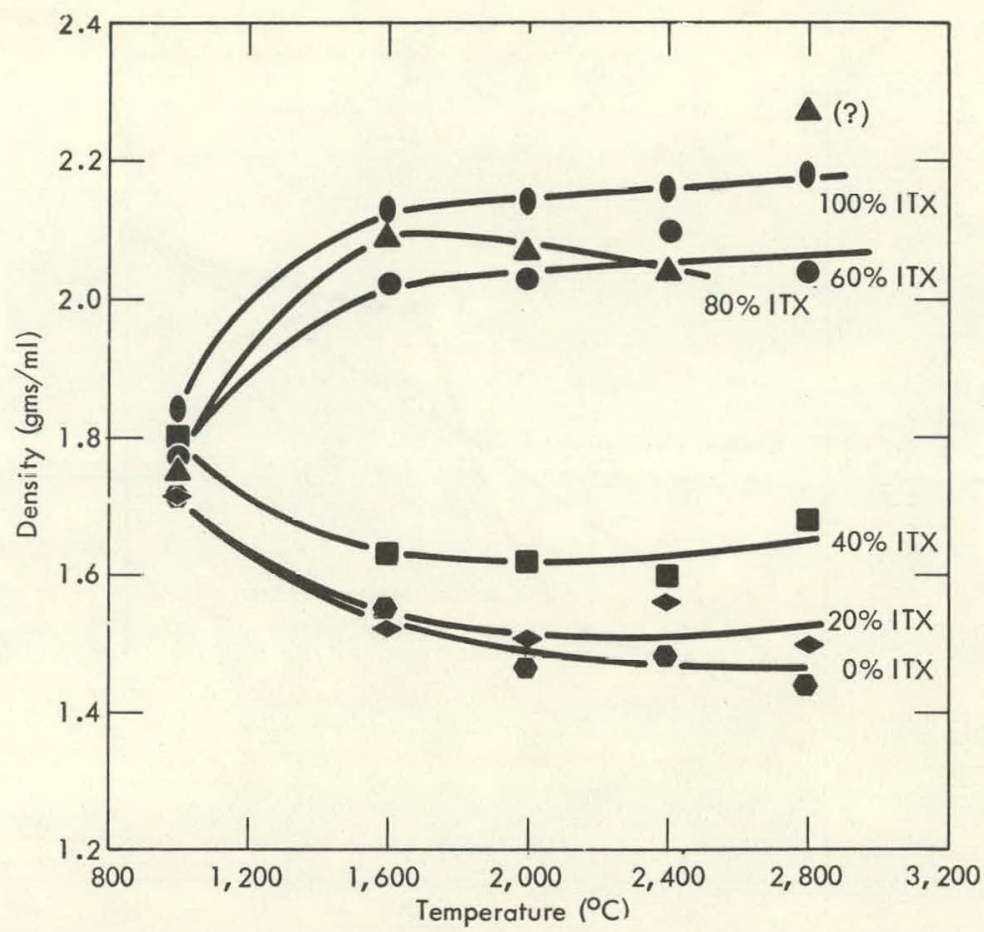

Figure 95. DENSITY OF CARBON SAMPLES DERIVED FROM MIXTURES OF AIR-CURED ISOTRUXENE AND POLYMERIZED FURFURYL ALCOHOL AS A FUNCTION OF THE TEMPERATURE AND PRECURSOR COMPOSITION.

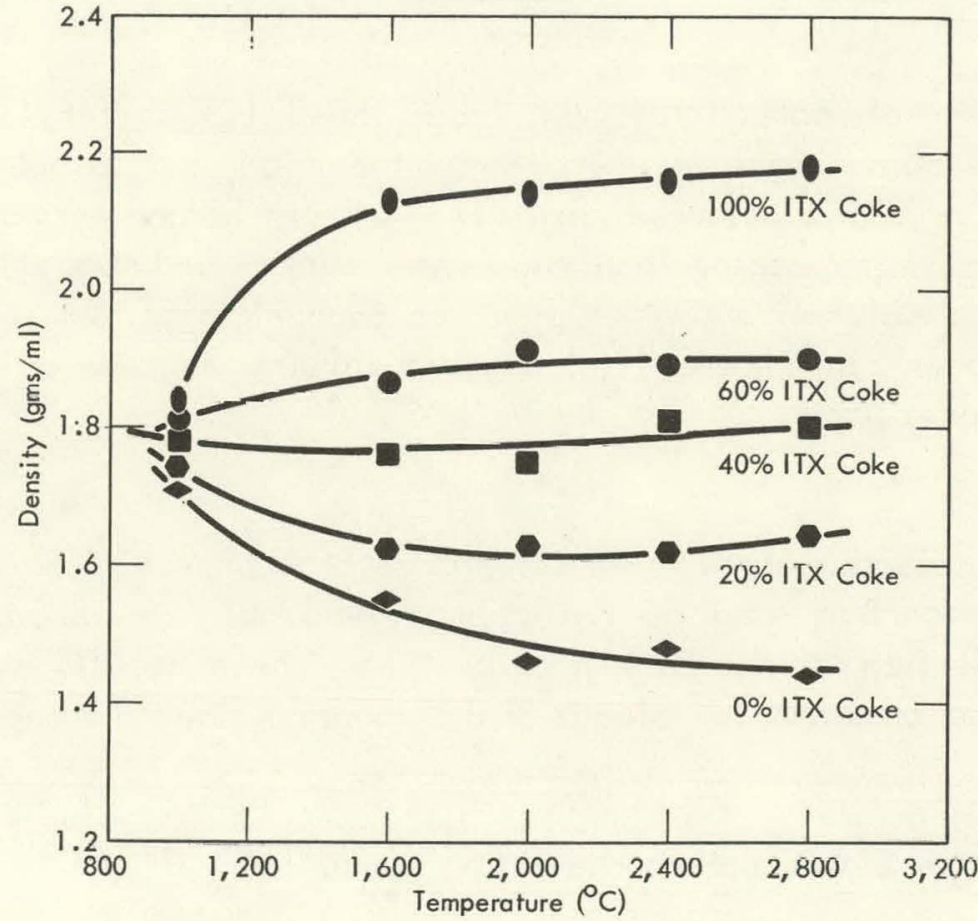

Figure 96. DENSITY OF CARBON MIXTURES (DERIVED BY BLENDING $1,000^{\circ} \mathrm{C}$ COKES FROM ISOTRUXENE AND POLYMERIZED FURFURYL ALCOHOL) AS A FUNCTION OF THE TEMPERATIIRF AND ISOTRUXENEDERIVED COKE CONTENT. 


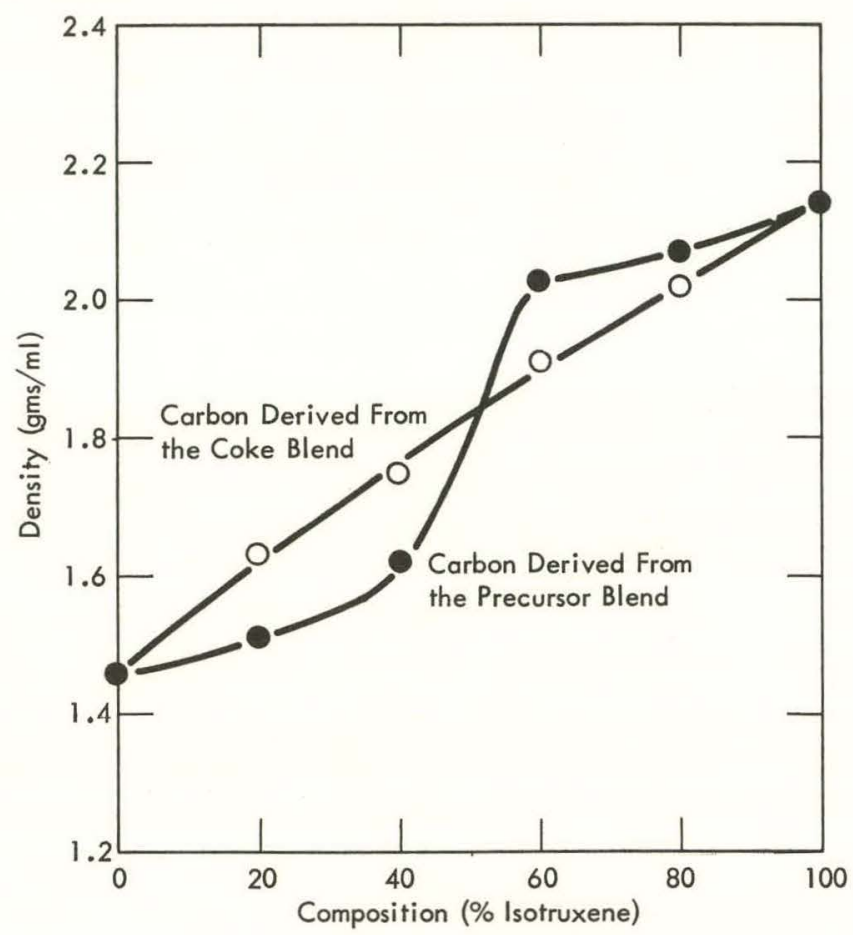

Figure 97. DENSITY OF CARBON SAMPLES (AFTER $2,800^{\circ} \mathrm{C}$ ) DERIVED FROM ISOTRUXENE-POLYMERIZED FURFURYL ALCOHOL MIXTURES AND MIXTURES OF THEIR RESPECTIVE COKES AS A FUNCTION OF THEIR COMPOSITIONS.

Microstructures of carbon derived from these ITX-furfuryl alcohol resin mixtures show some signs of precursor interaction, but largely depict heterogeneous carbon. This heterogeneity results from homopolymerization of the individual precursors rather than copolymerization, and suggests a separation into immiscible polymeric phases prior to carbonization. The various species of carbon present in Figure 99(c) suggest varying degrees of interaction between the two precursors.

In summary, blends of ITX with furfuryl alcohol resins produce largely a heterogeneous carbon, and do not appear desirable as an approach to controlled modification of the carbon properties. These results would tend to be typical of those obtained for blends of thermoplastic and thermosetting resins.

Isotruxene-Truxene-Acenaphthalene (ACN) Mixtures

A brief review of the characteristics of $A C N$-derived carbon is in order. The molecular structure of $A C N$ is: 


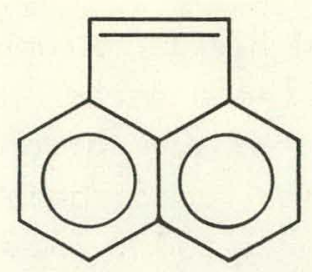

acenaphthalene

This compound polymerizes quite readily at temperatures above its melting point $\left(\sim 88^{\circ} \mathrm{C}\right)$. The DTA scan in Figure 100 shows a polymerization exotherm beginning at approximately $100^{\circ} \mathrm{C}$ and becoming quite intense at approximately $190^{\circ}$ C. Coke yields of ACN are typically $30-35$ percent. However, samples that were autoclave-polymerized prior to carbonization had much higher coke-yield values. As shown in Figure 101, coke yields approached maximum values of approximately 50 percent for $300^{\circ} \mathrm{C}$ autoclave temperatures (300 psi), and the resulting product was a low-melting $\left(50-75^{\circ} \mathrm{C}\right)$ pitch.

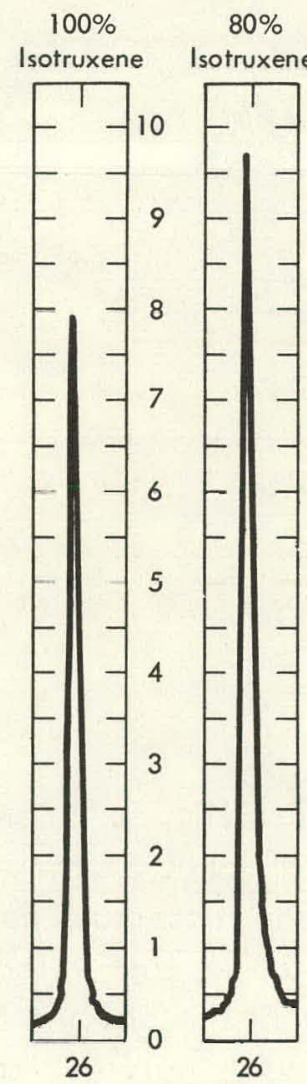

(a)

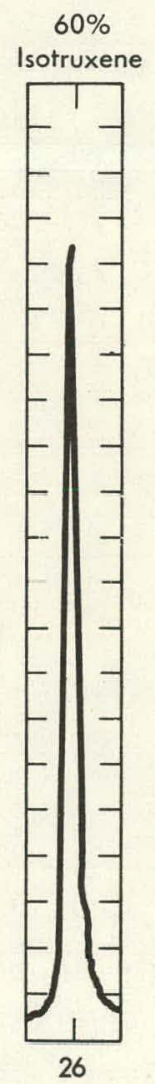

(c)

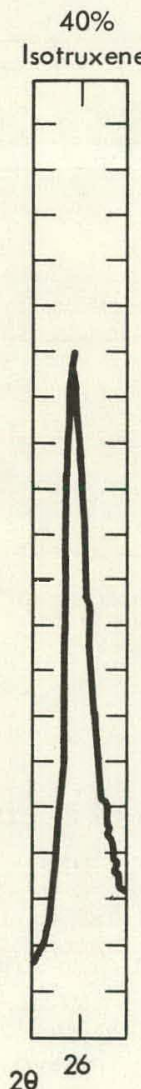

(d)

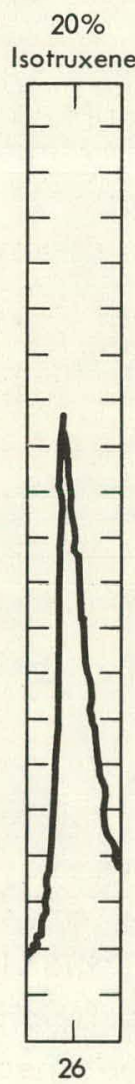

(e)

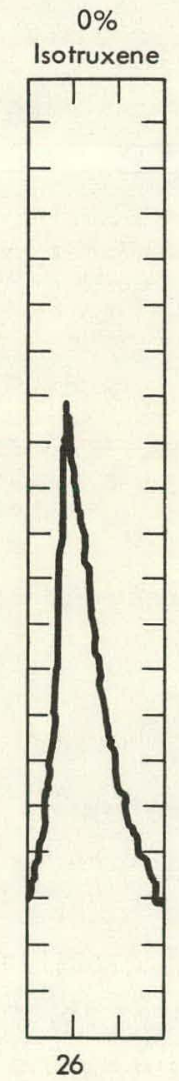

(f)

Figure 98. X-RAY DIFFRACTION SCANS (002 PLANE) OF CARBON (AFTER $2,800^{\circ} \mathrm{C}$ ) DERIVED FROM ISOTRUXENE-POLYMERIZED FURFURYL ALCOHOL MIXTURES. 
ACN produces a large-grain, highly anisotropic, crystalline form of carbon; and, as indicated in Figure 102, the carbon properties were not appreciably altered by designated variations in the carbonization conditions. Interlayerspacing values (d002) of $\mathrm{ACN}$-derived carbons were typically 3.57 to $3.60 \mathrm{~A}$, and crystallite-size $\left(L_{c}\right)$ values were 500 to $700 \mathrm{~A}$.

$A C N, I T X$, and truxene were blended in various proportions and the mixtures fired to $1,000^{\circ} \mathrm{C}$; and, subsequently, to $2,800^{\circ} \mathrm{C}$. Data for these samples are listed in Table 33. Since coke yields of the individual precursors are in the order: truxene $>$ isotruxene $>$ acenaphthalene, coke-yields values of the mixtures would be expected to reflect the composition, as do the data in Table 33. Likewise, since the graphitizability of the resulting carbons are in the order: acenaphthalene $>$ isotruxene $>$ truxene, carbon properties would be expected to vary with composition. This, too, is apparent from the X-ray data in Table 33. Changes in the microstructural characteristics of the carbons are shown as a function of the precursor composition in Figure 103. Thus, variations in the composition of this ternary mixture will permit a modification of the carbon properties, and could afford a method to control the carbon properties.

Table 33

PROPERTIES OF CARBON DERIVED FROM MIXTURES OF ACENAPHTHALENE, ISOTRUXENE, AND TRUXENE

\begin{tabular}{|c|c|c|c|c|c|c|c|}
\hline \multirow[b]{2}{*}{$\begin{array}{c}\text { Sample } \\
\text { Number (1) }\end{array}$} & \multirow{2}{*}{$\begin{array}{c}\text { Acenaphthalene } \\
\text { Content } \\
(\%)\end{array}$} & \multirow{2}{*}{$\begin{array}{l}\text { Isotruxene } \\
\text { Content } \\
(\%)\end{array}$} & \multirow{2}{*}{$\begin{array}{c}\text { Truxene } \\
\text { Content } \\
(\%)\end{array}$} & \multirow{2}{*}{$\begin{array}{l}\text { Coke Yiald } \\
\text { After } \\
1,000^{\circ} \mathrm{C} \\
(\%)\end{array}$} & \multicolumn{3}{|c|}{ Properties After $2,800^{\circ} \mathrm{C}$} \\
\hline & & & & & $\begin{array}{l}\text { do04 } \\
\text { (A) }\end{array}$ & $\mathrm{g}$ factor & $\begin{array}{l}L_{c} \\
\text { (A) }\end{array}$ \\
\hline G1 & 66.6 & 16.7 & 16.7 & 33 & 1.6800 & 0.942 & 479 \\
\hline $23 \mathrm{H}$ & 41.7 & 41.7 & 16.6 & 51 & 1.6808 & 0.918 & 351 \\
\hline $16 \mathrm{H}$ & 16.7 & 66.6 & 16.7 & 74 & 1.6914 & 0.671 & 100 \\
\hline G15 & 33.3 & 33.3 & 33.4 & 72 & - & - & - \\
\hline
\end{tabular}

(1) Compounds were blended as powders, then air cured to $250^{\circ} \mathrm{C}$ in a programmed cycle prior to carbonization.

\section{CONCLUSIONS}

The data presented in this report show the versatility of indene chemistry in producing precursors to carbon. A series of organic materials can be derived from indene and can, in turn, furnish carbon materials having diverse properties. Collectively, the data strongly supports the contention that carbon properties are solely a function of the chemistry of the precursor in that the initial structure and the mechanisms associated with polymerization dictate properties of a derived carbon. Thus, the production and use of synthetic precursors that are well characterized should aid in problems associated with the reproducibility of raw material and carbon properties. 

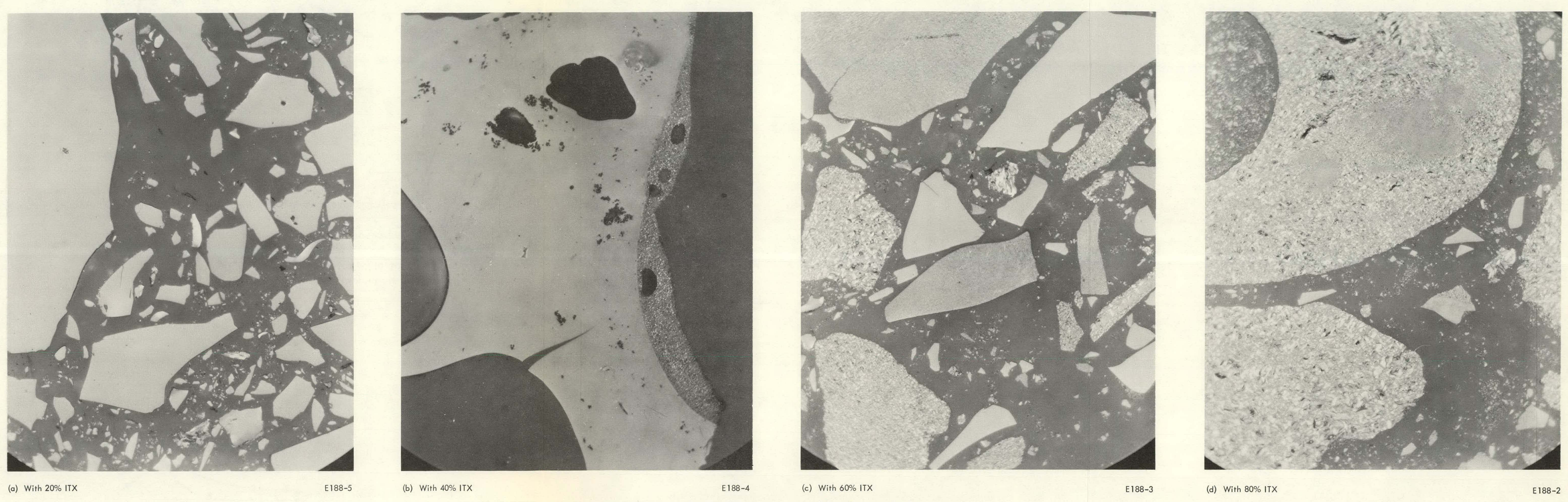


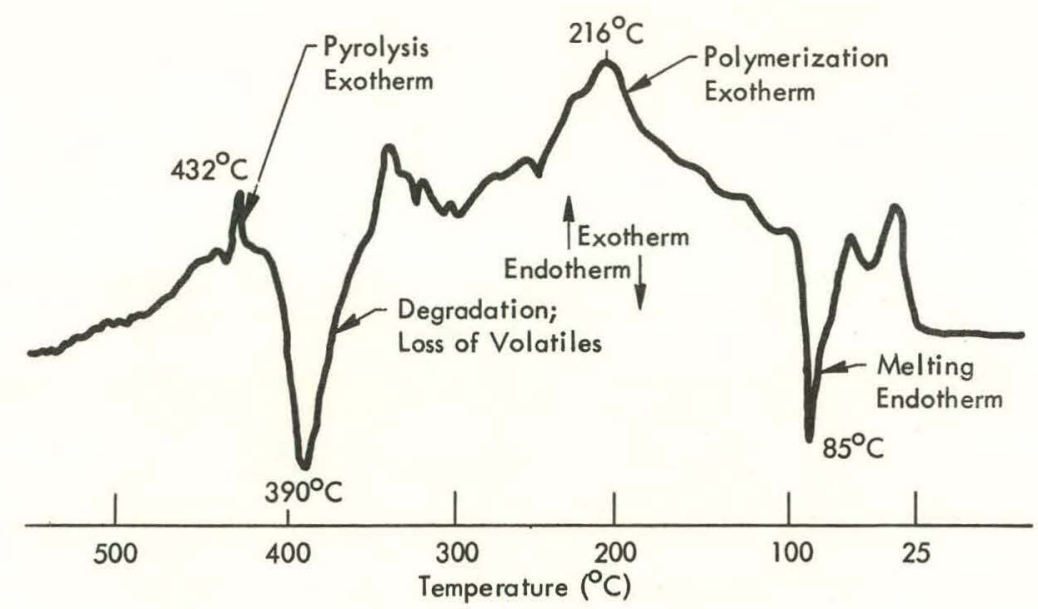

Figure 100. DIFFERENTIAL THERMAL ANALYSIS SCAN OF ACENAPHTHALENE. (Heating Rate, $6^{\circ} \mathrm{C} / \mathrm{min}$ )

In addition, the controlled modification of carbon properties was demonstrated by the use of procedures which modify the precursor materials. These were:

1. Induced crosslinking by

a. vinylation of compounds containing active methylene groups using acetylene under pressure, and by
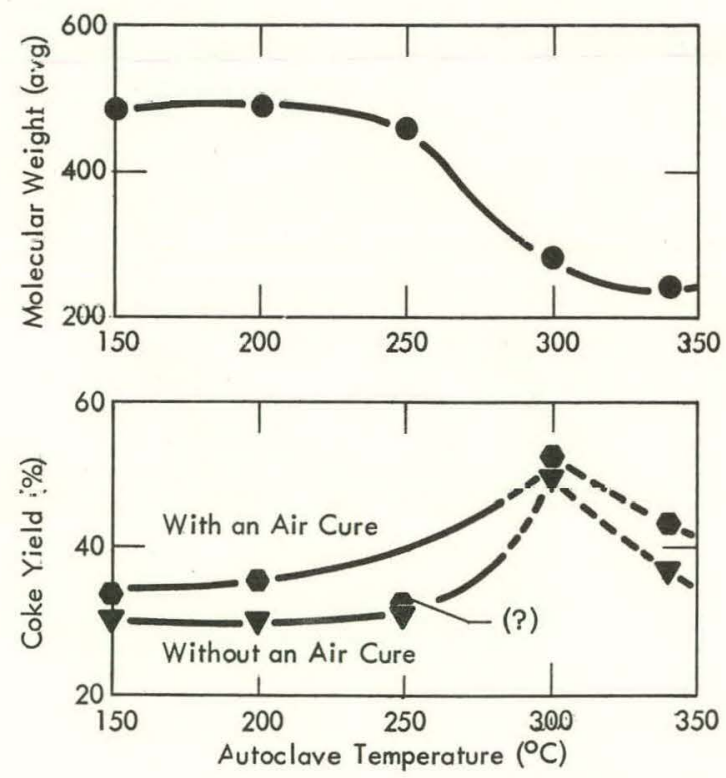

Figure 101. COKE YIELD (AFTER $1,000^{\circ} \mathrm{C}$ ) AND AVERAGE MOLECULAR WEIGHT OF AUTOCLAVE POLYMERIZED ACENAPHTHALENE AS FUNCTIONS OF THE AUTOCLAVE TEMPERATURE. 

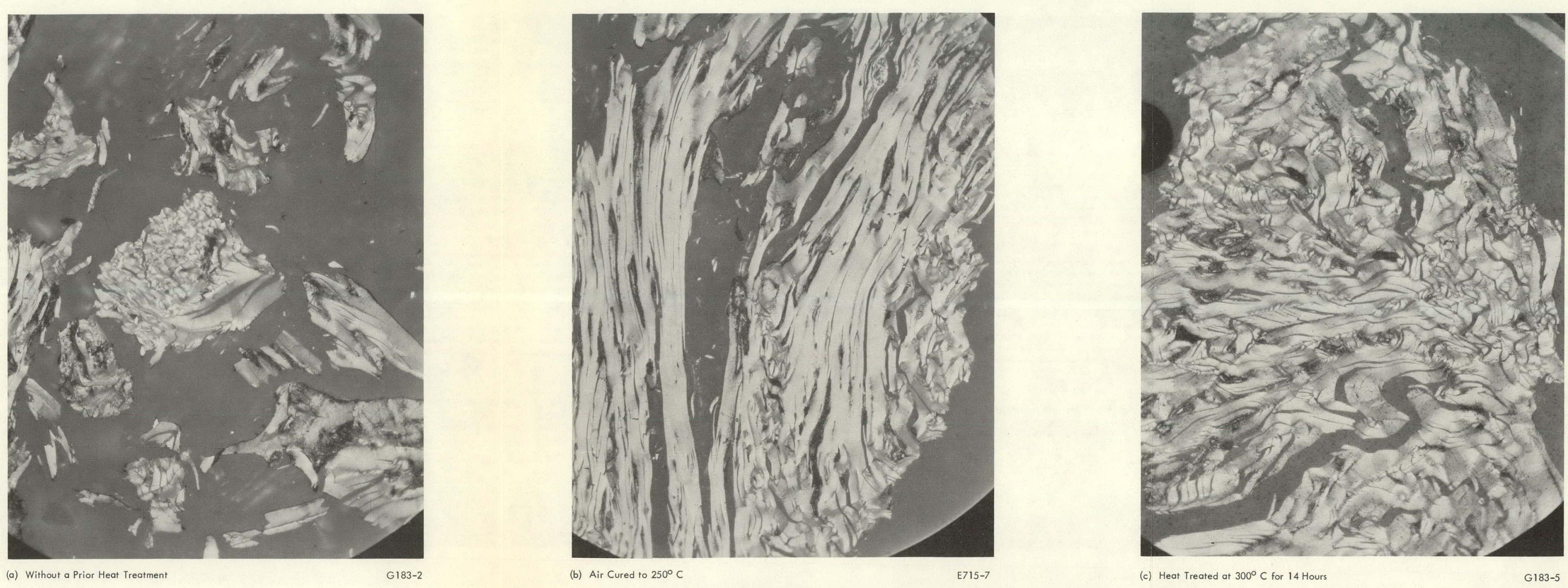

Figure 102. MICROSTRUCTURES OF CARBON SAMPLES (AATER $2,800^{\circ} \mathrm{C}$
DERIVED FROM ACENAPHTALENE, (250X) 

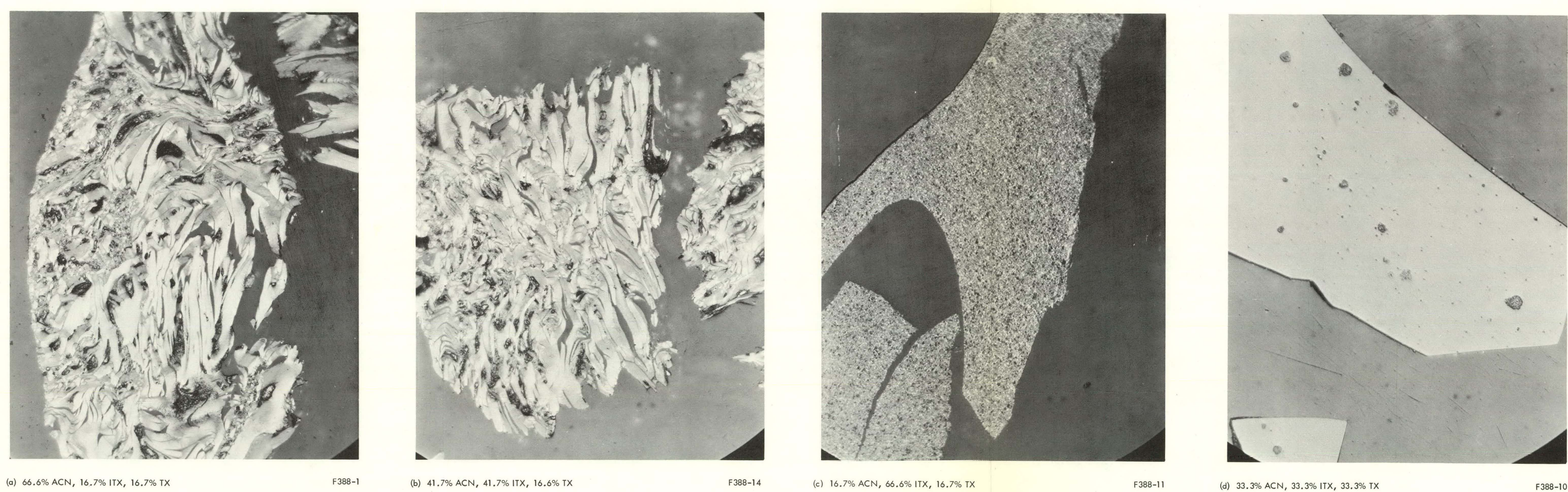

Figure 103. MICROSTRUCTURES OF CARBON SAMPLES (AFTER 2,800 C) DERIVD FROM ARR-CURED MIXTURES
OF ACENAPHTHALNE, ISOTRUXENE, AND TRUXENE. (Batch Ll-99-9; 250X)

(d) $33.3 \%$ ACN, $33.3 \%$ ITX, 33. $3 \%$ IX 
b. inclusion of pyromellitic dianhydride (PMDA) which thermally decomposes to produce reactive benzyne intermediates.

2. Oxidative polymerization using air, oxygen gas, or sulfur.

3. Blending in variable compositions two or more precursor materials that would, if carbonized individually, give rise to carbons with diverse properties. 


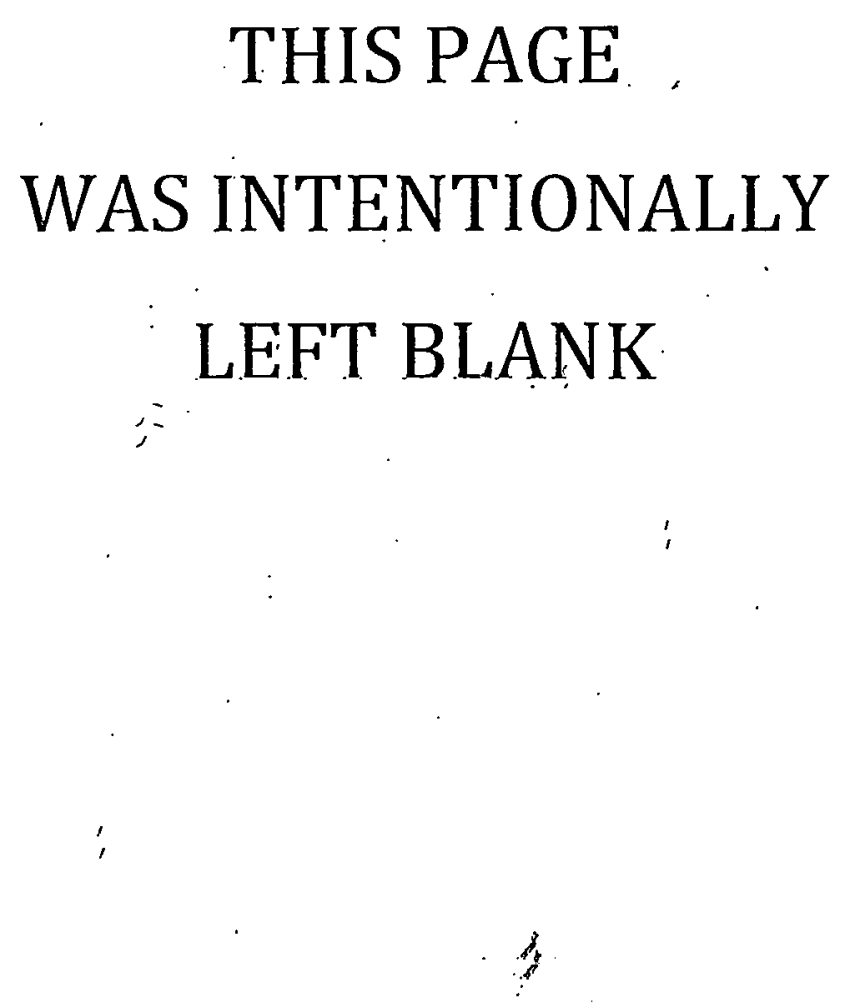




\section{REFERENCES}

(1) Mantell, C.L.; Carbon and Graphite Handbook, P l; Interscience Publishers, New York (1968).

(2) Ibid, $p 44$.

(3) Ibid, p 61.

(4) Ibid, pp 8-10, 72, 76, and 106.

(5) El Dorsey, A and Donnay, G.; "A New Allotropic Form of Carbon from the Ries Crater", Science, 161, P 363 (1968).

(6) Whittaker, A. G. and Kinter, P.; "Carbon: Observations on the New Allotropic Form", Science, 165, p 589 (1969).

(7) Korshak, V. V., et al; "The Synthesis and Properties of Linear Modifications of Carbon", Vestnik Adademii Navk SSSR, 38, pp 89-91 (1968).

(8) Smith, W. E., Napier, B., and Harper, W. L.; Preparation and Characterization of Hydrocarbon Derivatives of Indene, $Y-1712$; Union Carbide Corporation-Nuclear Division, Oak Ridge Y-12 Plant, Oak Ridge, Tennessee; April 21, 1970.

(9) Ruland, W.; "X-Ray Diffraction Studies on Carbon and Graphite", $P 1$ in Chemistry and Physics of Carbon, 4; Edited by P. L. Walker, Jr, Marcel Dekker, Inc, New York (1968).

(10) Maire, J. and Mering, J.; Proceedings of the Fourth Carbon Conference, p 345; Pergamon Press, New York (1960).

(11) Karpukhin, P. P. and Luchenko, A. I.; "Vinylation of Cyclic Hydrocarbons", Zhur Priklad Khim, 32, pp $1386-1390$ (1959).

(12) Rudy, E.; "Ternary Phase of Equilibria in Transition Metal-BoronCarbon-Silicon Systems; Part V" in Compendium of Phase Diagram Data, AFML-TR-65-2; Air Force Materials Laboratory, Wright-Patterson Air Force Base, Ohio; May 1969. 


\section{ACKNOWLEDGEMEN.TS}

The authors wish to express their thanks to R. L. Jamison, Jr, E. 'T. Creech, and others in the Special Samples Group of the $Y-12$ Analytical Laboratory for their cooperation and assistance in the analyses of materials described in this report; to W. T. Rainey, Jr, of the ORNL Analytical Chemistry Division for obtaining and evaluating the mass spectral data; to J. M. Napier of the Y-12 Development Division for making equipment and technology available that were useful in the carbonization studies; and to S. G. Campbell and A. G. Dobbins of the $Y-12$ Development Division for assisting in preparing the metallurgical samples. In addition, the authors wish to thank J. M. Googin, UCC-ND Senior Staff Consultant, for valuable advice during this study. 